\title{
37. THE GEOCHEMISTRY, MINERALOGY, AND PETROLOGY OF BASALTS FROM THE WEST PHILIPPINE AND PARECE VELA BASINS AND FROM THE PALAU-KYUSHU AND WEST MARIANA RIDGES, DEEP SEA DRILLING PROJECT LEG 59
}

\author{
David P. Mattey, Nicholas G. Marsh, and John Tarney, ${ }^{1}$ Department of Geological Sciences, \\ University of Birmingham, Birmingham B15 2TT, England
}

\section{INTRODUCTION}

Legs 59 and 60 of the International Phase of Oceanic Drilling (IPOD) were designed to study the nature and history of volcanism of the active Mariana arc, its currently spreading inter-arc basin (the Mariana Trough), and the series of inactive basins and intervening ridges that lie to the west (Fig. 1). The older basins and ridges were drilled during Leg 59 as the first part of a transect of single-bit holes drilled in each major basin and ridge. The eastern part of the transect - the tectonically active region-was drilled during Leg 60.

The evolution of island-arc volcanos and magma genesis associated with lithospheric subduction remain some of the most complex petrologic problems confronting us. Many types of source material (mantle, oceanic crust, continental crust) and an unusually wide range of possible physical conditions at the time of magma genesis must be identified even before the roles of partial melting and subsequent magma fractionation, mixing, and contamination can be assessed.

The present-day Mariana arc is characterized by a steeply dipping Benioff zone, which becomes essentially vertical at depths greater than $200 \mathrm{~km}$ (Kanamori, 1977). The slope of the Benioff zone is thought to be greatest below the active volcanos of the northern Mariana arc and to become shallower (to the south) beneath the inactive volcanic islands of Guam and Saipan. Subduction below the Mariana arc is relatively aseismic, and coupling between the upper and lower (subducted) plates is weak or effectively nonexistent (Kanamori, 1977). More recent results from drilling in the trench and fore-arc regions of the Mariana arc not only suggest the lack of an accretionary sedimentary prism, but extensional tectonics within the fore-arc sediments suggest a tensional stress regime within the trench region (Leg 60 Scientific Party, 1979). Thus there is clear evidence that the Pacific plate is subducting spontaneously with relatively little resistance from the upper plate.

During the Pliocene, the Mariana Trough began to open about a north-south trending axis, effectively splitting the West Mariana Ridge from the active Mariana arc (Karig, 1975). The topography and mag-

\footnotetext{
${ }^{1}$ Dr. Tarney's present address is Department of Geology, University of Leicester, Leicester LE 17 RH, England.
}

netic fabric of the Parece Vela Basin suggest a similar origin-the sundering of the Palau-Kyushu Ridge in the late Oligocene (Karig, 1975). The origin of the West Philippine Basin is less clear, however, and the age and magnetic fabric of this basin remain controversial. Recent studies of rocks dredged from the Mariana Trough (Hart et al., 1972), the Lau Basin (Hawkins, 1976), and the Scotia Sea (Saunders and Tarney, 1979) all reveal that these basins are floored by basalts geochemically similar to basalts erupted at mid-ocean ridges. The formation of active back-arc basins (e.g., the East Scotia Sea, Barker 1970) in the Mariana Trough (Karig et al., 1978 ) is considered by many authors to be the result of seafloor spreading broadly similar to that associated with a mid-ocean ridge (e.g., Karig, 1971).

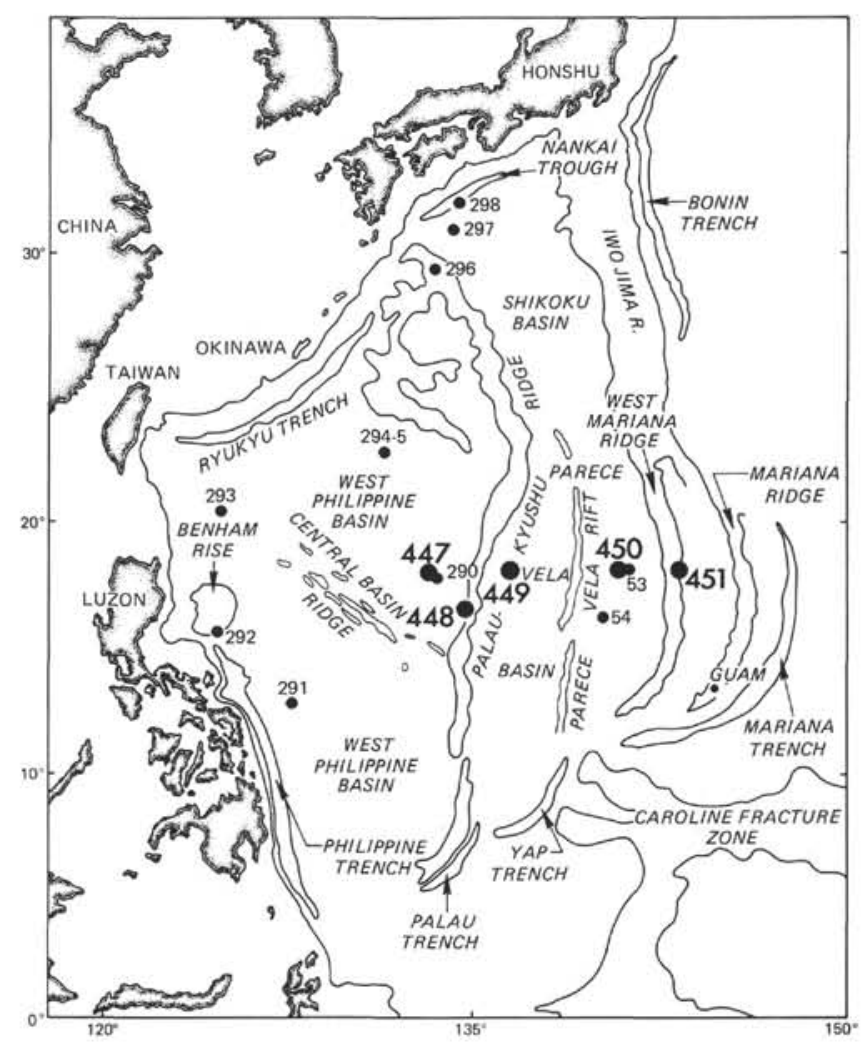

Figure 1. Map of the Philippine Sea showing the locations of the holes drilled during Leg 59. (The positions of the holes drilled during the second part of the Mariana transect [IPOD Leg 60] are also included, along with those drilled in the area during DSDP Legs 6, 31, and 58.) 
Igneous rocks were successfully recovered from both the West Philippine (Hole 447A) and Parece Vela basins (Holes 449 and 450). Excellent basement penetration and a high degree of core recovery were attained in Hole 447A. Detailed mineralogical and geochemical studies of the rocks from this hole have provided clear insight into the various magmatic processes involved during ocean-crust formation.

The Leg 59 South Philippine Sea traverse included sites on two major north-south submarine ridges (the Palau-Kyushu and West Mariana ridges). These features are interpreted by Karig $(1972,1975)$ to be eroded and subsided remnant volcanic arcs, and their formation is presumed to be broadly analogous to the currently active Mariana-Bonin island-arc system. Although the Philippine Sea area has been studied by dredge surveys (Dietrich et al., 1978) and by two earlier DSDP Legs (6 and 31), relatively little information was obtained on the structure and chemical composition of these arcs. During Leg 59, the Palau-Kyushu and West Mariana ridges were successfully drilled to depths of over 900 meters; in particular, at Site 448 (PalauKyushu Ridge), 46 igneous and volcaniclastic units were recognized. These detailed sections provide a unique opportunity to study the chemical and petrologic structure of young island arcs and to test whether evolutionary trends exist during cyclic island-arc and marginal-basin formation in the Philippine Sea.

As a result of the two tectonic environments studied, this report on the petrology and geochemistry of the basalts from holes drilled during Leg 59 is divided into two parts. Part 1 describes the mineralogy, petrology, and geochemistry of basalts from the West Philippine and Parece Vela basins (the "basin sites," i.e., Holes 447A, 449, and 450); Part 2 discusses the geochemistry of igneous rocks from the Palau-Kyushu and West Mariana ridges (the "'arc sites,"' i.e., Holes 448, 448A, and 451).

\section{SAMPLING AND ANALYTICAL TECHNIQUES}

Whole-rock analyses for major and trace elements and microprobe analyses of fresh glasses, phenocrysts, and xenocrysts have been undertaken during this study of Leg 59 basalts. Wherever possible, for whole-rock analysis, at least two samples were taken from every cooling unit identified at each site.

Whole-rock analyses for major and trace elements were performed by X-ray fluorescence (XRF) spectrometry (see Tarney et al. [1979]; and Marsh et al. [in press] for details of method, precision, and accuracy) using a Phillips PW1450 automated X-ray spectrometer. Analyses were carried out using 46-mm diameter pressed-powder discs. For the major elements a chromium or rhodium target tube was used; a tungsten target was used for $\mathrm{Ni}, \mathrm{Cr}, \mathrm{Zr}, \mathrm{Nb}, \mathrm{La}, \mathrm{Ce}$, and $\mathrm{Nd}$ and a molybdenum target for $\mathrm{Y}, \mathrm{Rb}, \mathrm{Sr}, \mathrm{Th}, \mathrm{Ba}$, and $\mathrm{Pb}$.

The abundance of glass margins recovered from the "basin sites" (Holes 447A, 449, and 450) enabled representative fresh glasses to be studied in parallel with the whole-rock sampling scheme. In many cases, both whole-rock and fresh-glass analyses are available for each cooling unit, if not the same pillow. From 55 chilled margins studied, 40 glass and over 500 phenocryst analyses were obtained using the energy-dispersive electron microprobe at the Department of Mineralogy and Petrology, University of Cambridge. Glasses were analyzed using a defocussed beam approximately $100 \mu \mathrm{m}$ in diameter with an accelerating voltage of $15 \mathrm{kV}$. Spectra were counted for $80 \mathrm{~s}$ and processed using an iterative peak stripping program. At least two glass spectra were processed per sample and the results averaged to give the final analysis. Wollastonite, jadeite, and olivine standards were analyzed periodically to monitor the instrumental drift. Representative standard analyses are summarized in Table 1 , along with the results of 15 replicate analyses of a tholeiitic augite. Estimates of the lower limit of detection are also given in Table 1. The detection limits of elements such as $\mathrm{K}$ and $\mathrm{P}$ are too high for these elements to be analyzed in many glasses; similarly, $\mathrm{Na}$ and $\mathrm{Mg}$ were not detected in many pyroxenes and plagioclases, respectively. The abundances of the minor elements $\mathrm{Ni}, \mathrm{Mn}, \mathrm{Cr}, \mathrm{Co}$, and $\mathrm{V}$ are considered reliable only if present in quantities greater than $0.3 \mathrm{wt} . \%$.

Unfortunately, during transit from the ship to Birmingham, 13 samples from Hole 447A became separated from their labelled capsules. These samples were analyzed even though it is not known exactly which of the 13 labelled intervals they correspond to. The results of these analyses are presented in this report, and the data are plotted on some diagrams. The samples have been labelled alphabetically (Table 4). All of these samples correspond closely in chemistry to one or another of the established chemical units at Hole 447A.

\section{PART 1: THE "BASIN SITES"}

\section{The West Philippine Basin}

The West Philippine Basin, the deepest and oldest of the marginal basins of the Philippine Sea complex, is bounded by the Palau-Kyushu and Oki Daito ridges to the east and north-east and by the Ryukyu and Philippine trench systems to the north-west and west. The basin in divided by an axial zone of higher relief, the socalled Central Basin Ridge or Philippine Ridge, which trends north-west-south-east (Fig. 1). Considerable attention has been focussed on the possible origins of this basin (e.g., Karig 1975). Symmetry about the Central Basin Ridge is observed in the bathymetry (Ben-Avraham et al., 1972), the magnetic-anomaly pattern (Watts et al., 1977), and the heat-flow distribution (Watanabe et al., 1977), which suggest symmetrical basin formation about this features. Several hypotheses have been proposed to explain the formation of this basin, including:

1) entrapment of Cenozoic oceanic crust generated by symmetrical mid-ocean-ridge-type spreading about the Central Basin Ridge behind a Palau-Kyushu subduction zone (Ben-Avraham et al., 1972); and

2) symmetrical Cenozoic mid-ocean-ridge-type spreading (connected to the Kula Ridge spreading system by a

Table 1. Analytical results for electron-microprobe standards.

\begin{tabular}{|c|c|c|c|c|c|c|c|}
\hline & \multirow[b]{2}{*}{$D^{\mathrm{a}}$} & \multicolumn{2}{|c|}{ Wollastonite } & \multicolumn{2}{|c|}{ Olivine } & \multicolumn{2}{|c|}{ Augite } \\
\hline & & $\bar{X}^{b}$ & rec.c & $\bar{X}^{\mathrm{b}}$ & rec.c & $\bar{X}^{\mathrm{b}}$ & $\sigma^{\mathrm{d}}$ \\
\hline \multicolumn{8}{|c|}{$\begin{array}{l}\text { No. of } \\
\text { Analyses (N) }\end{array}$} \\
\hline $\mathrm{SiO}_{2}$ & 0.1 & 51.39 & 51.34 & 40.19 & 40.82 & 50.07 & 0.51 \\
\hline $\mathrm{TiO}_{2}$ & 0.05 & - & - & - & - & 0.50 & 0.07 \\
\hline $\mathrm{Al}_{2} \overline{\mathrm{O}}_{3}$ & 0.1 & - & - & - & - & 3.09 & 0.27 \\
\hline $\mathrm{Cr}_{2} \mathrm{O}_{3}$ & 0.05 & - & - & - & - & 0.33 & 0.05 \\
\hline $\mathrm{FeO}$ & 0.05 & 0.31 & - & 9.38 & 9.54 & 6.64 & 0.24 \\
\hline $\mathrm{MnO}$ & 0.05 & 0.07 & - & - & - & - & - \\
\hline $\mathrm{MgO}$ & 0.15 & - & - & 48.48 & 49.12 & 15.01 & 0.28 \\
\hline $\mathrm{CaO}$ & 0.15 & 47.56 & 48.02 & - & - & 20.80 & 0.27 \\
\hline $\mathrm{Na}_{2} \mathrm{O}$ & 0.3 & - & - & - & - & - & - \\
\hline $\mathrm{K}_{2} \mathrm{O}$ & 0.05 & - & - & - & - & - & - \\
\hline $\mathrm{NiO}$ & 0.15 & - & - & 0.28 & 0.28 & - & - \\
\hline
\end{tabular}

${ }^{a} D=$ lower limit of detection.

$\mathrm{b} \bar{X}=$ mean of $\mathrm{N}$ analyses.

$\mathrm{c}_{\mathrm{d}}$ rec. $=$ recommended value .

$\mathrm{d}_{\sigma}=$ standard deviation. 
Palau-Kyushu transform fault) followed by entrapment to form a marginal basin behind the newly created Palau-Kyushu subduction zone (Hilde et al., 1977).

Site 447 is located on the eastern side of the West Philippine Basin between the Central Basin Ridge and the Palau-Kyushu Ridge, about $35 \mathrm{~km}$ northwest of DSDP Site 290 (Leg 31). Hole 447A penetrated basement at 113 meters and successfully cored a further 183.5 meters of basalt.

\section{The Parece Vela Basin}

The Parece Vela Basin, smaller and shallower than the West Philippine Basin, is bounded by the West Mariana Ridge to the east, and by the Palau-Kyushu Ridge to the west. To the north, the Parece Vela Basin merges into the Shikoku Basin, eventually terminating in the Nankai Trough, whereas to the south it is bounded by a relatively complex system of arcs, trenches, and fracture zones (the Palau, Yap, and Mariana trenches). Karig (1975) construes that the ridges flanking the basin to the east and west were active in the mid-Tertiary, prior to sundering and formation of the Parece Vela Basin in the early Miocene. A north-south zone of higher relief containing an axial trough (Parece Vela Rift) is interpreted by Karig $(1971,1975)$ as the final position of the spreading axis. Although north-south magnetic lineations have been identified in the Shikoku Basin (Watts and Weissel, 1975), lineations are anomalously absent in the Parece Vela Basin (Keating, this volume).

Two holes, 449 and 450 , were drilled in the Parece Vela Basin on each side of the Parece Vela Rift. Hole 449 is located in the west side of the basin, where thin sediments cover exceptionally rough basement. Penetration was successful to a depth of 151.5 meters, and 40.5 meters of basaltic basement were cored before poor hole stability terminated drilling operations. Hole 450 was drilled into the distal end of the thick wedge of volcani- clastic sediment that extends westward from the West Mariana Ridge, $150 \mathrm{~km}$ east of the Parece Vela Rift. Coring was successful to a depth of 340 meters, the final 7 meters being drilling into basalt. The "acoustic" basement in the area of Site 450, however, is interpreted to be at least 500 meters sub-bottom. At two other sites, 53 and 54 (DSDP Leg 6), shallow basalts and andesites were unexpectedly encountered in the sediment wedge in this area; Fischer, Heezen et al. (1971) interpreted these as intrusive in origin. There is clear evidence that the basalt recovered from Hole 450 is also intrusive (see the material presented later in this chapter), and the question is raised as to whether the basalt recovered represents true ocean (or marginal-basin) basement.

\section{Lithology and Petrography}

The following section describes the lithology and petrography of phenocrysts and megacrysts present in the basalts from Holes 447A, 449, and 450. Detailed petrographic descriptions are given in the corresponding site reports. Chilled glassy margins were studied wherever possible in conjunction with existing thin sections prepared during Leg 59. Stated phenocryst compositions are based on microprobe determinations unless otherwise stated. Abundances of phenocrysts quoted are only estimates; the basalts are described as "aphyric" if they contain less than 5\% total phenocrysts, "sparsely phyric" if they contain from $5 \%$ to $10 \%$ total phenocrysts, or "phyric" if they contain from $10 \%$ to $20 \%$ total phenocrysts. Relevant petrographic data from each hole are summarized and compared in Table 2.

\section{Hole 447A}

The basement at this site consists of 18 basalt lava flows, which were divided into six lithologic units by the shipboard party (Fig. 2) using lithologic, petrographic,

Table 2. Summary of petrographic features of basalts from Holes 447A, 449, and 450 .

\begin{tabular}{|c|c|c|c|c|c|c|c|c|}
\hline \multirow{2}{*}{$\frac{\text { Hole }}{\text { Unit }^{\mathrm{a}}}$} & \multicolumn{5}{|c|}{$447 \mathrm{~A}$} & \multicolumn{2}{|c|}{449} & \multirow[t]{2}{*}{450} \\
\hline & L1, L2 & L3a & L3b-d & L4, L5 & L6 & Upper & Lower & \\
\hline $\begin{array}{l}\text { No. of flows } \\
\text { Phenocrysts }\end{array}$ & $\begin{array}{l}5 \\
\text { Pl-Ol-Sp } \\
\text { aphyric to } \\
\text { sp. phyric }\end{array}$ & $\begin{array}{c}1 \\
\begin{array}{c}\text { Pl-Px-Ol-Sp } \\
\text { phyric }\end{array}\end{array}$ & $\begin{array}{c}3 \\
\text { Pl-Ol-Px } \\
\text { sp. phyric }\end{array}$ & $\begin{array}{c}3 \\
\text { Pl-Ol } \\
\text { sp. phyric }\end{array}$ & $\begin{array}{c}6 \\
\text { Ol-Pl-Sp } \\
\text { sp. phyric }\end{array}$ & $\begin{array}{c}1 ? \\
\text { Pl-Ol-Px-Sp } \\
\text { sp. phyric }\end{array}$ & $\begin{array}{c}1 ? \\
\text { Pl } \\
\text { sp. phyric }\end{array}$ & $\begin{array}{c}1 ? \\
\text { Pl-Px } \\
\text { phyric }\end{array}$ \\
\hline \multicolumn{9}{|c|}{ Paragenetic sequence } \\
\hline Phenocrysts & $\begin{array}{c}\mathrm{Sp} \\
\mathrm{Pl}(\mathrm{Sp})^{\mathrm{b}} \\
\mathrm{Pl}+\mathrm{Ol}\end{array}$ & $\begin{array}{c}\mathrm{P} 1[\mathrm{Sp}]^{\mathrm{b}} \\
\mathrm{Pl}+\mathrm{Px} \\
\mathrm{Pl}+\mathrm{Px}+\mathrm{Ol}\end{array}$ & $\stackrel{\mathrm{Pl}}{\mathrm{Pl}+\mathrm{Ol}+\mathrm{Px}}$ & $\stackrel{\mathrm{Sp}}{\mathrm{Pl}+\mathrm{Ol}}$ & $\begin{array}{c}\mathrm{Sp} \\
\mathrm{Ol}(\mathrm{Sp})[\mathrm{Sp}] \mathrm{b} \\
\mathrm{Ol}+\mathrm{Pl}\end{array}$ & $\begin{array}{c}\mathrm{Sp} \\
\mathrm{Ol}+\mathrm{Pl}(\mathrm{Sp})^{\mathrm{b}} \\
\mathrm{Pl}+\mathrm{Ol}+\mathrm{Px}\end{array}$ & $\mathrm{Pl}$ & $\begin{array}{c}\mathrm{Pl} \\
\mathrm{Pl}+\mathrm{Px}\end{array}$ \\
\hline Groundmass & $\begin{array}{c}\mathrm{Pl}+\mathrm{Ol}+\mathrm{Px} \\
\mathrm{Px} \text {, ores }\end{array}$ & $\begin{array}{l}\mathrm{Pl}+\mathrm{Px} \\
\mathrm{Px} \text {, ores }\end{array}$ & $\begin{array}{l}\mathrm{Pl}+\mathrm{Px} \\
\mathrm{Px}, \text { ores }\end{array}$ & $\begin{array}{l}\mathrm{Pl}+\mathrm{Ol}+\mathrm{Px} \\
\mathrm{Px}, \text { ores }\end{array}$ & $\begin{array}{c}\mathrm{Pl}+\mathrm{Ol}+\mathrm{Px} \\
\mathrm{Px} \text {, ores }\end{array}$ & $\begin{array}{c}\mathrm{PI}+\mathrm{Ol}+\mathrm{Px} \\
\mathrm{Px}, \text { ores }\end{array}$ & $\begin{array}{l}\mathrm{Pl}+\mathrm{Px} \\
\mathrm{Px} \text {, ores }\end{array}$ & $\begin{array}{l}\mathrm{Pl}+\mathrm{Px} \\
\mathrm{Px} \text {, ores }\end{array}$ \\
\hline \multicolumn{9}{|l|}{ Xenocrysts } \\
\hline Spinel & - & $\mathrm{A}^{\mathrm{c}}$ & - & - & $B^{d}$ & - & - & - \\
\hline Plagioclase & - & An95, An75 & - & - & An75-80[Sp] ${ }^{\mathrm{b}}$ & - & - & - \\
\hline Olivine & - & ? & $?$ & - & ? & - & - & - \\
\hline Pyroxene & - & $\mathrm{Cr}$-endiopside & $\mathrm{Cr}$-endiopside & - & - & - & - & - \\
\hline Xenoliths & - & - & - & - & anorthosite & - & - & - \\
\hline
\end{tabular}

a Units L1 through L6 correspond to Units 6 through 11 in the Site 447 Report.

b Parentheses denote equilibrium (phenocryst) inclusions; brackets denote xenocryst inclusions.

$\mathrm{c}=$ as inclusions in plagioclase phenocrysts.

$\mathrm{d}_{\mathrm{B}}=$ as free-floating resorbed crystals and inclusions in plagioclase xenocrysts. 


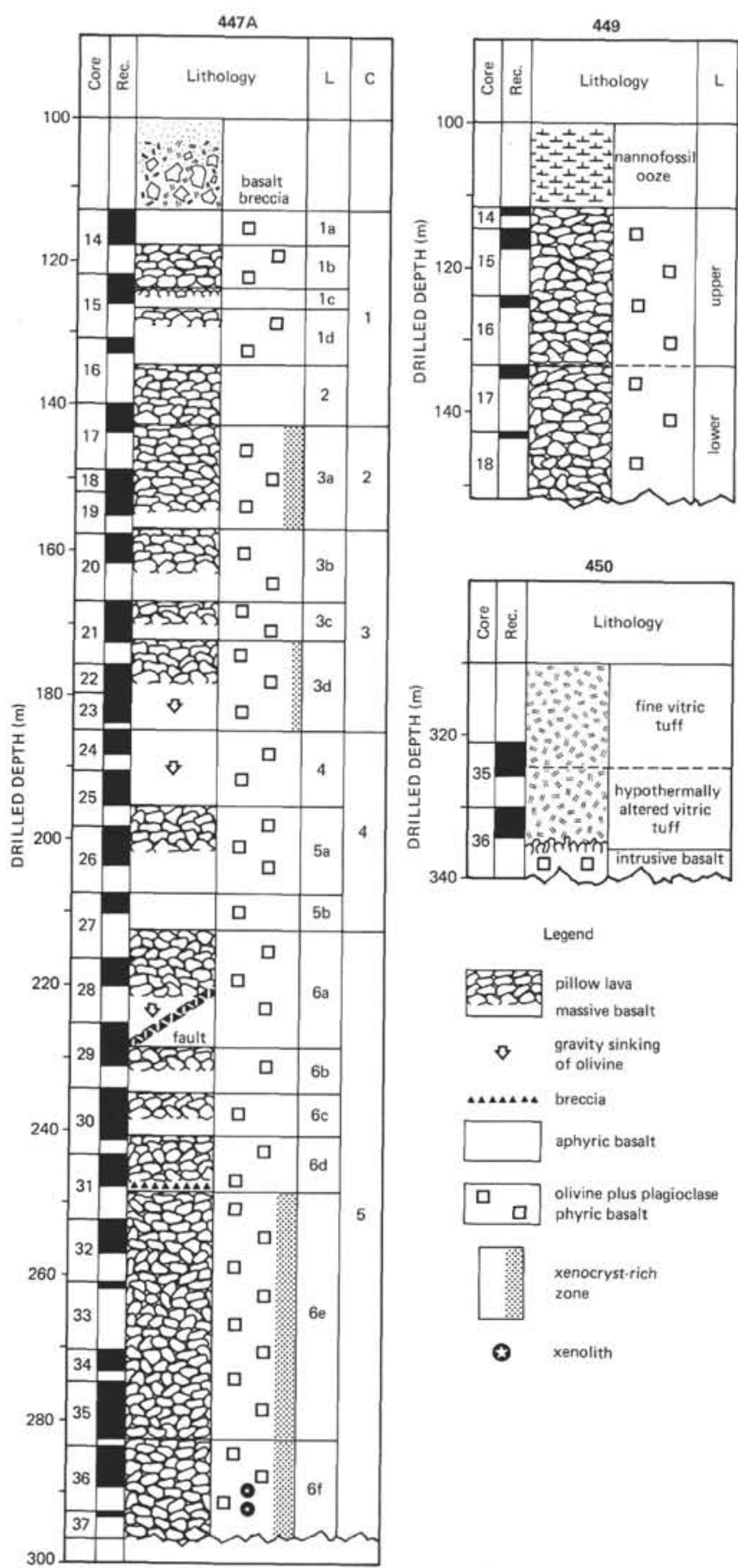

Figure 2. Stratigraphic sections of igneous basement penetrated at Holes 447A, 449, and 450. (Lithologic [L] and chemical [C] units are distinguished. In Hole $447 \mathrm{~A}$, the lithologic units correspond to Units 6-11 in the Site 447 report, this volume.)

and paleomagnetic data. Recovery averaged $60 \%$, and many long uninterrupted cores were obtained, notably through pillowed sequences. The stratigraphy of this site is relatively clear, and the positioning and thicknesses of the various units are considered to be fairly accurate.

The six major lithologic units are notated L1 and L6 (these numbers correspond to Units 6-11 in the site report), and each incorporates from 1 to 6 individual cooling units or flows (notated L1a, L1b, etc.). The cooling units are of three types:

1) massive lava flows characterized by aphanitic margins and doleritic cores (e.g., L1a, L4, and L5b);

2) pillowed lava flows (e.g., L1b, L2, and L6d-f); and

3) "pillowed massive flows." Many units appear to consist of an upper layer of pillow lava that grades downward into a petrographically and chemically indistinguishable lower massive flow (e.g., L1c, L3a-d, L4, L5a, and L6a-c). The rhythmic sequence of pillow lava plus massive basalt is a striking feature of the stratigraphy of this hole (Fig. 2).

Unit LI $(18.5 \mathrm{~m})$. This unit includes four cooling units of aphyric to plagioclase-olivine-spinel-phyric basalt. Plagioclase phenocrysts are generally euhedral to subhedral and average $1 \mathrm{~mm}$ in size. Crystals typically display marked oscillatory zoning, with cores ranging in composition from $\mathrm{An}_{81}$ to $\mathrm{An}_{75}$. Plagioclase and olivine also form glomerophyric clots, often with olivine partly enclosing the plagioclase. Olivine crystals show a small range in composition $\left(\mathrm{Fo}_{87-85}\right)$ and are slightly zoned (both normally and reversed). Reddish brown chrome spinels form small (50-150 $\mu \mathrm{m})$ octahedra and are usually found as inclusions in plagioclase crystals.

Unit L2 $(9.5 \mathrm{~m})$. This single flow is composed of rather uniform aphyric pillow basalt. Glassy margins, however, reveal rare phenocrysts of plagioclase and olivine. Plagioclase crystal cores range in composition from $\mathrm{An}_{91}$ to $\mathrm{An}_{76}$ and show strong oscillatory zoning. Olivine crystals are euhedral or partly skeletal, unzoned, and have compositions in the range $\mathrm{Fo}_{86}$ to $\mathrm{Fo}_{85}$.

Unit $L 3(44.0 \mathrm{~m})$ is a distinctive lithologic unit consisting of four flow units of plagioclase-olivine-clinopyroxene-spinel-phyric basalt. The uppermost flow unit (L3a) is the most porphyritic unit drilled at this site and contains single euhedral phenocrysts of plagioclase (0.5-3 mm in size, core compositions $\mathrm{An}_{90}-\mathrm{An}_{75}$ ), rare augite (up to $1 \mathrm{~mm}$ in size), and less common olivine (0.2-0.8 mm, core compositions $\mathrm{Fo}_{84}-\mathrm{Fo}_{81}$, averaging $\mathrm{Fo}_{82}$ ). Plagioclase and augite (Plate 3, Fig. 4) often form extensive glomerophyric clots 1 to $4 \mathrm{~mm}$ across, the augite granular and strained, with patchy extinction. Olivine phenocrysts are partly skeletal (Plate 1, Fig. 4) and appear to have crystallized later in the paregenetic sequence. The remainder of this unit (L3b-d) is considerably less porphyritic, containing only rare phenocrysts of augite, but is otherwise petrographically similar to Unit L3a. Phenocrysts are concentrated near the base of the lower massive portions of Units L3C and L3d as a result of gravitational settling.

In addition to the phenocrysts and glomerocrysts described above, Unit L3 contains many examples of crystals apparently markedly out of equilibrium with the host glass. These include:

1) Large (1-3 mm) ragged or rounded xenocrysts of plagioclase both more and less calcic than the euhedral plagioclase phenocrysts. The more calcic crystals (Plate 2, Fig. 5) fall in a narrow compositional range from 
$A n_{96}$ to $A n_{95}$, are unzoned, and have smooth rounded outlines, whereas the less calcic crystals are sometimes reversed zoned, with cores as sodic as $\mathrm{An}_{75}$, mantled by plagioclase of a similar composition to that of the euhedral phenocrysts $\left(\mathrm{An}_{90-75}\right)$. The latter crystals are often more ragged in outline.

2) Small $(0.2-0.5 \mathrm{~mm})$ oval grains of $\mathrm{Cr}$-rich endiopsidic augite $\left(\mathrm{Wo}_{42} \mathrm{En}_{50} \mathrm{Fs}_{8}\right)$, many of which are almost completely digested (Plate 1, Fig. 5; Plate 3, Figs. 1-3, 5). Several crystals contain small blebs of glass, possibly the result of magmatic corrosion.

3) A few plagioclase phenocrysts contain rounded grains of relatively $\mathrm{Al}$-rich chromium spinel (Plate 2, Fig. 7). These spinels are also tentatively interpreted as xenocrysts and will be discussed in more detail later in this report.

It is emphasized that the xenocrysts found in Unit L3 (most commonly in L3a) represent considerably less than $1 \%$ of the rock.

Unit $L 4(9.0 \mathrm{~m})$ consists of a single flow of massive sparsely phyric plagioclase-olivine basalt. No glass margins were recovered from this unit. Plagioclase phenocrysts, up to $1 \mathrm{~mm}$ in size, are euhedral and range in composition from approximately $\mathrm{An}_{85}$ to $\mathrm{An}_{75}$ (optical determination). Small subhedral olivine pseudomorphs $(0.5 \mathrm{~mm})$ are concentrated near the base of the unit, suggesting that posteruptional gravitational settling took place.

Unit L5 $(15.0 \mathrm{~m})$ comprises two "pillowed massive flows" of plagioclase-olivine-sparsely phyric basalt. Glassy pillow margins contain euhedral, slightly zoned phenocrysts of plagioclase $(0.3-1.0 \mathrm{~mm})$, with core compositions $\mathrm{An}_{82}$ to $\mathrm{An}_{80}$. The smaller subhedral or skeletal olivine phenocrysts are unzoned and are the most magnesian $\left(\mathrm{Fo}_{88}\right)$ olivines from this site.

Unit L6 (at least $89 \mathrm{~m}$ ) includes six flows of pillowed basalts, the three uppermost flows being of the compound "pillowed-massive" type. The basalts are all olivine-plagioclase-spinel-phyric with euhedral crystals of olivine (0.5-1.0 mm, $\mathrm{Fo}_{87}-\mathrm{Fo}_{86}$ ) (Plate 1, Fig. 1) and euhedral crystals of plagioclase (1 mm, $\left.A n_{90}-A n_{80}\right)$ (Plate 1, Fig. 2). Early-formed octahedra of reddish brown magnesiochromite are common as inclusions in olivine phenocrysts or as freely floating crystals (Plate 2, Figs. 1-6). Units L6e and L6f are petrographically similar to the four overlying units, except for the presence of xenocrysts and xenoliths. The xenocrysts are dominantly ragged (corroded or abraded) crystals of plagioclase $\left(\mathrm{An}_{85}-\mathrm{An}_{80}\right)$, often as large as $1.5 \mathrm{~mm}$ in size (Plate 1, Fig. 6, Plate 2, Fig. 6). Some crystals contain inclusions of reddish, relatively aluminous chromianspinel, sometimes as large as $0.5 \mathrm{~mm}$ (Plate 1, Fig. 6). Isolated crystals of corroded, relatively aluminous spinel (chromian-spinel) are sometimes found either as discrete crystals or as inclusions in olivine phenocrysts, often alongside equilibrium, less-aluminous, euhedral spinels (Plate 2, Fig. 4). At the base of Unit L6f, a few xenoliths of anorthosite were recovered; up to $5 \mathrm{~cm}$ in size, these are composed entirely of cumulate plagioclase of composition $\mathrm{An}_{82}$ to $\mathrm{An}_{80}$ (Plate 1, Fig. 7).

\section{Hole 449}

The 7 meters of pillowed basalt recovered at this site can be tentatively divided into two lithologic units (Fig. 2 ), which probably represent at least two separate lava flows.

The upper basalts (approximately $24 \mathrm{~m}$ ) contain phenocrysts of euhedral oscillatory zoned plagioclase, ranging in size from 0.5 to $2 \mathrm{~mm}$. Core compositions range from $A n_{86}$ to $A n_{72}$, and many crystals show strong reverse zoning. Olivine phenocrysts are restricted to these upper basalts and are euhedral to partly skeletal, with core compositions varying from $\mathrm{Fo}_{86}$ to $\mathrm{Fo}_{85}$. Rare glomerocrysts of augite occur, commonly in association with plagioclase (usually less calcic than the isolated phenocrysts). Reddish brown octahedra of spinel (magnesiochromite) are relatively common as inclusions in both olivine and plagioclase. These range in size from 100 to $200 \mu \mathrm{m}$.

The lower pillowed basalts (approximately $16 \mathrm{~m}$ ) are sparsely plagioclase-phyric; olivine, clinopyroxene, and spinel phenocrysts are rare.

\section{Hole 450}

Almost 2 meters of pillow basalt were recovered from this hole after penetration of a monotonous series of gray vitric tuffs. Approximately 8.5 meters of reddish brown hydrothermally altered tuffs overlie the basalt (Fig. 2), and the sediment/basalt contact is marked by a $1-\mathrm{cm}$-thick band of pale brown, baked tuff that has been intruded by minute blebs of basalt glass. Pockets of a similar baked tuff are also found between pillows. This basalt was interpreted by the shipboard party as a pillow lava that foundered into, or even intruded, soft wet sediment while sufficiently hot to thermally metamorphose the adjacent sediments (i.e., a subsediment flow).

The basalt contains phenocrysts of plagioclase and rare clinopyroxene. Plagioclase phenocrysts are generally large (1-3 mm) and euhedral, with core compositions of $\mathrm{An}_{95}$ to $\mathrm{An}_{85}$ for the larger isolated crystals and $\mathrm{An}_{85}$ to $\mathrm{An}_{73}$ for the smaller subhedral crystals that are glomerophyric with clinopyroxene.

\footnotetext{
Alteration

Most of the basalts recovered from Holes 447A, 449, and 450 have suffered moderate to extensive low-temperature seawater alteration (halmyrolysis). In hand specimen, the more holocrystalline interiors of pillows and massive flows are typically pale gray with frequent brown mottling. The brown coloration, in particular, is closely associated with veins and fracture surfaces. Less crystalline basalt forming the margins of flows and pillows has a more uniform brown appearance. This type of alteration appears to be related to the ease of access to seawater along cracks, joints, and generally more permeable areas. There is no clear relationship between the degree of alteration and depth of burial. The alteration is relatively uniform and never exceeds zeolite grade.
} 
A more pervasive type of alteration, not necessarily associated with weathered surfaces, veins, and cracks, results in the replacement of pyrogenic phases by secondary minerals. There is widespread replacement of olivine by brown smectites and granular opaque oxides.

Unaltered olivine is generally only preserved in fresh glass margins. Interstitial glass is similarly replaced by brown smectites, calcite, and sometimes zeolite. Plagioclase, although more resistant to alteration, may be veined or partly replaced by calcite and zeolites. Clinopyroxene, however, remains entirely fresh. Veins and vesicles are lined or filled with a variety of secondary minerals, including pale blue, green, and brown smectites, calcite, zeolites, and sometimes pyrite.

Fresh glass is preserved in cooling rinds of pillow basalts and in the chilled margins of more massive flows. In thin section, incipient hydration to honeyyellow palagonite is common, usually as veins, or as a transitional zone between the fresh glass and partly crystalline variolitic material. In more altered areas the entire glass rind is altered to a banded aggregate of deep green and brown smectites.

\section{Geochemical Results}

\section{Chemistry of the Residual Glasses}

Fresh-glass analyses are important for three reasons: (1) they provide information on the lower limit of $\mathrm{MgO}$, $\mathrm{CaO}$, and $\mathrm{Al}_{2} \mathrm{O}_{3}$ contents of primitive liquids; (2) chemical variation resulting from phenocryst accumulation is reduced; and (3) the chemical effects of seawater alteration are effectively eliminated. Fresh-glass margins were fortunately very common at all three "basin" sites drilled during Leg 59, and it was possible to determine the liquid compositions of all major lithologies.

The compositional range of the Leg 59 "'basin"'-glass analyses is illustrated in the form of oxide- $\mathrm{MgO}$ variation diagrams in Figure 3. Representative analyses from Hole 447A are listed in Table 3 . The data clearly fall into seven tightly clustered chemical groups: five from Hole 447A and one each from Holes 449 and 450. The lack of internal variation within Holes 449 and 450 compared to Hole $447 \mathrm{~A}$ is probably a consequence of the greater penetration at the latter site.

Each of the five compositional groups (chemical units) from Hole 447A is approximately equivalent to one of the lithologic units described earlier; a detailed chemical stratigraphy is presented in the following section, in conjunction with the whole-rock major- and trace-element data. These invariant liquid compositions, however, are representative of up to 80 meters of basalts, and the 18 flow units are in fact represented by only 5 magma compositions.

In terms of major elements, the data from Hole 447A form a relatively well-defined linear trend, with $\mathrm{Al}_{2} \mathrm{O}_{3}$ and $\mathrm{CaO}$ correlating positively and $\mathrm{TiO}_{2}, \mathrm{SiO}_{2}, \mathrm{FeO}$, and $\mathrm{Na}_{2} \mathrm{O}$ correlating negatively with $\mathrm{MgO}$. Considering the data as a whole, we note the following general intersite compositional differences. The basalts from Holes 449 and 450 are less magnesian $(\sim 7.5 \% \mathrm{MgO})$ than are the majority of basalts from Hole 447A

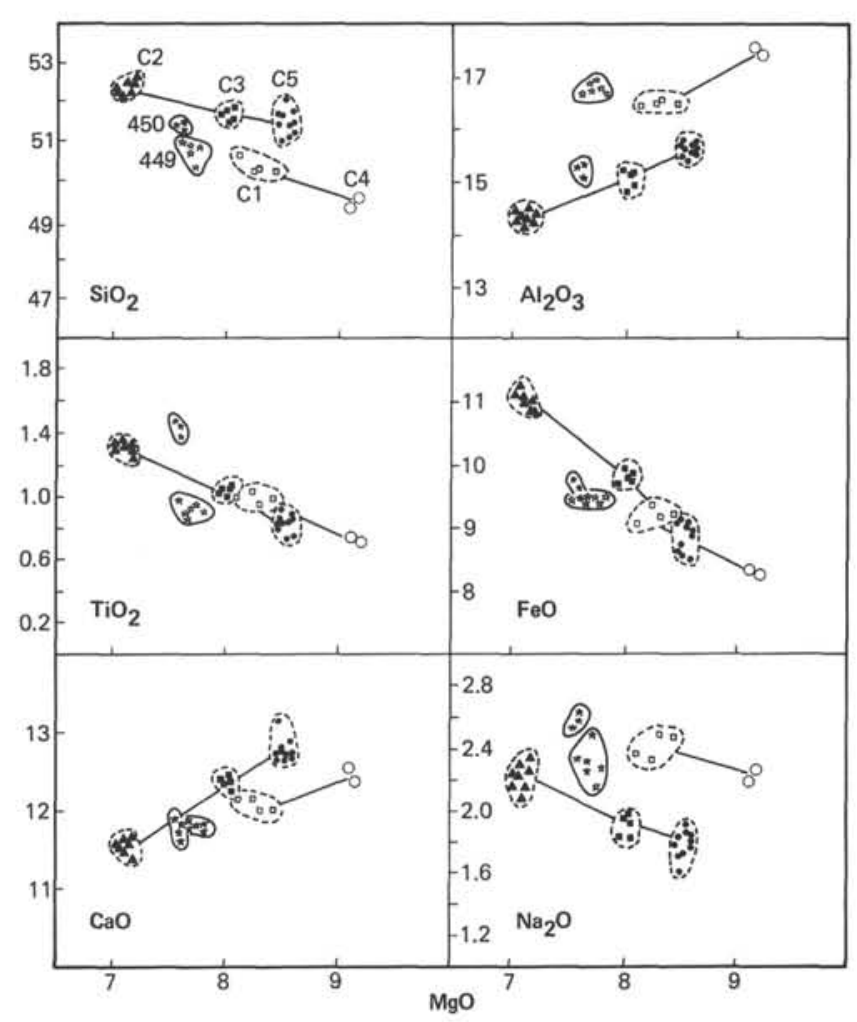

Figure 3. Major-element oxide versus $\mathrm{MgO}$ variation diagrams for glasses from Hole 447A (Chemical Units $\mathrm{C1}-\mathrm{C} 5$ are indicated) and Holes 449 and 450 .

$(8.0-8.5 \% \mathrm{MgO})$. Hole 450 glasses are broadly similar to those from Hole 449, with the exception of $\mathrm{TiO}_{2}$ and $\mathrm{Al}_{2} \mathrm{O}_{3}$, which are somewhat richer and poorer, respectively. A comparison of Hole 447A (West Philippine Basin) with Holes 449 and 450 (Parece Vela Basin) shows that the latter basalts are relatively poor in $\mathrm{SiO}_{2}$, $\mathrm{FeO}$, and $\mathrm{CaO}$, and Hole 449 basalts are notably richer than those of Hole $447 \mathrm{~A}$ in $\mathrm{Al}_{2} \mathrm{O}_{3}$.

\section{Whole-Rock Major- and Trace-Element Geochemistry}

\section{Hole 447A}

Forty-five whole-rock analyses of basalts from this hole are presented in Table 4. All the analyses are similar to typical mid-ocean ridge basalt (MORB). Compared to the glass analyses, however, these wholerock analyses show a considerably greater range of variation, particularly in $\mathrm{MgO}$, which varies from $5 \%$ to $11 \%$. Other major-element concentrations are broadly similar to those in the glasses, with the notable exception of $\mathrm{K}_{2} \mathrm{O}$. The abundance of $\mathrm{K}_{2} \mathrm{O}$ in the majority of glasses is below the limit of detection of the electronmicroprobe system, i.e., less than $0.05 \%$, a value typical of fresh MORB. In the whole-rock analyses, however, $\mathrm{K}_{2} \mathrm{O}$ is higher by an order of magnitude, reaching levels as high as $1.4 \%$ in some samples.

The major- and trace-element data conform to five coherent groups equivalent to the glass groups described in the previous section. To illustrate the down-hole chemical stratigraphy, representative data are plotted 


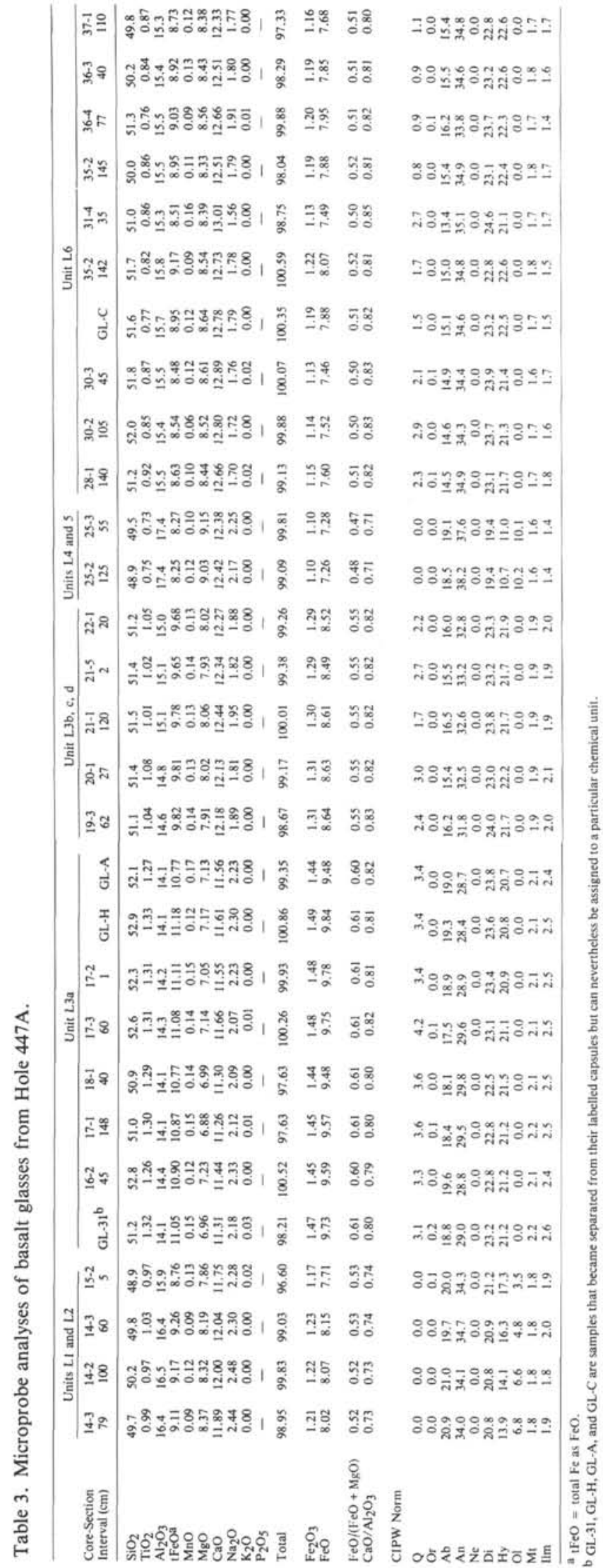

against stratigraphic height in Figure 4. Four chemical hiatuses are observed, marked both by differences in absolute abundances of elements such as $\mathrm{TiO}_{2}, \mathrm{Al}_{2} \mathrm{O}_{3}, \mathrm{Zr}$, $\mathrm{Y}, \mathrm{Sr}$, and $\mathrm{Cr}$ and by various inter-element ratios, including $\mathrm{Ca} / \mathrm{Al}, \mathrm{Ti} / \mathrm{Zr}$, and $\mathrm{Y} / \mathrm{Zr}$. These discontinuities, occurring at the base of Lithologic Units L2, L3a, L3d, and L5, indicate that from one to six chemically similar lava flows were erupted followed by a distinct change in magma composition. Thus five chemical units are clearly distinguished at this site, based on both whole-rock and residual glass analyses. These chemical units, notated $\mathrm{C} 1$ through $\mathrm{C} 5$ in downhole order of appearance, are related to the lithologic units as follows: $\mathrm{C} 1=\mathrm{L} 1, \mathrm{~L} 2 ; \mathrm{C} 2=\mathrm{L} 3 \mathrm{a} ; \mathrm{C} 3=\mathrm{L} 3 \mathrm{~b}$, c, d; C4 = L4, L5; C5 = L6 (see Fig. 2).

Whole-rock and glass average compositions for each chemical group are presented in Table 5. Although a slight systematic compositional shift is observable, each of the glass and whole-rock average pairs are similar. Glasses tend to be richer in $\mathrm{SiO}_{2}$ and $\mathrm{MgO}$ and poorer in $\mathrm{TiO}_{2}, \mathrm{Na}_{2} \mathrm{O}$, and $\mathrm{K}_{2} \mathrm{O}$. These systematic differences may be partly attributed to the different methods of analysis employed but can also be accounted for in terms of alteration and/or crystal accumulation.

Figure 4 shows that within each chemical unit there is a small range in the absolute abundances of many major and trace elements. Certain inter-element ratios, however, are strongly bimodal. In particular, ratios of hygromagmatophile (HYG) elements (i.e., those with low mineral/melt partition coefficients) fall into two groups (Fig. 4C). For example, Units $\mathrm{C} 1$ and $\mathrm{C} 4$ have $\mathrm{Ti} / \mathrm{Zr}$ 94, $\mathrm{Y} / \mathrm{Zr} \sim 0.39$, and $\mathrm{P} / \mathrm{Zr} \sim 4$, in contrast to Units $\mathrm{C} 2, \mathrm{C} 3$, and $\mathrm{C} 5$, which have ratios of $125,0.53$, and 8 , respectively (Table 5). These element pairs are plotted in Figures 5, 6, and 7, and the data clearly define two independent linear fractionation trends. Thus the basalts from Units $\mathrm{C} 1$ and $\mathrm{C} 4$ have lower $\mathrm{Ti} / \mathrm{Zr}, \mathrm{Y} / \mathrm{Zr}$, and $\mathrm{P} / \mathrm{Zr}$ ratios compared with those from Units C2, C3, and C5. Two magma types can therefore be distinguished.

Major-element differences between the more magnesian basalts of each magma type can be recognized in Figure 3 and Table 5; namely, for a given $\mathrm{MgO}$ content there are absolute differences in $\mathrm{SiO}_{2}(49.0-50.5 \%$ for $\mathrm{C} 1, \mathrm{C} 2 ; 51-52 \%$ for $\mathrm{C} 2, \mathrm{C} 3, \mathrm{C} 5)$ and in $\mathrm{Al}_{2} \mathrm{O}_{3}$ (16.5$17.5 \%$ for $\mathrm{C} 1, \mathrm{C} 2 ; 14.0-15.5 \%$ for $\mathrm{C} 2, \mathrm{C} 3, \mathrm{C} 5)$. Units $\mathrm{C} 1$, and $\mathrm{C} 4$ are also richer in $\mathrm{Na}_{2} \mathrm{O}$ and poorer in $\mathrm{CaO}$, but there are no differences in $\mathrm{FeO}$ or $\mathrm{TiO}_{2}$ contents.

Whole-rock and glass data are plotted in Figures 8 and 9 on the $\mathrm{Di}-\mathrm{Hy}-\mathrm{Ol}$ and the $\mathrm{Px}-\mathrm{Ol}-\mathrm{Pl}$ projections of the normative basalt tetrahedron of Yoder and Tilley (1962). The iron oxidation state (again, total iron is quoted as $\mathrm{FeO}$ unless otherwise stated) has been recalculated as $\mathrm{Fe}^{3+} / \mathrm{Fe}^{2+}+\mathrm{Fe}^{3+}=0.15$ for the calculation of the CIPW norms. On the Di-Ol-Hy (Fig. 8) projection, whole-rock analyses of basalts belonging to Units $\mathrm{C} 1$ and $\mathrm{C} 4$ plot on or close to the $\mathrm{Di}-\mathrm{Ol}$ join. Unit $\mathrm{C} 2, \mathrm{C} 3$, and $\mathrm{C} 5$ basalts are on average more $\mathrm{Hy}-$ 
Table 4. Analyses of basalts from Hole 447A.

\begin{tabular}{|c|c|c|c|c|c|c|c|c|c|c|c|c|c|c|c|c|c|c|c|c|c|c|}
\hline Core & 14 & 15 & 15 & 15 & 16 & 17 & 17 & 17 & 18 & 19 & 21 & 21 & 22 & 22 & 23 & 23 & 24 & 25 & 27 & 28 & 29 & 29 \\
\hline Section & 3 & 2 & 3 & 4 & 2 & 1 & 2 & 3 & 2 & 3 & $i$ & 2 & 1 & 3 & 1 & 4 & 2 & 3 & 1 & 1 & 2 & 3 \\
\hline Interval & 41 & 35 & 69 & 13 & 37 & 52 & 25 & 105 & 116 & 84 & 99 & 99 & 34 & 9 & 63 & 76 & 125 & 10 & 41 & 112 & 80 & 15 \\
\hline $\mathrm{Si}_{2}$ & 47.7 & 47.8 & 48.7 & 47.8 & 47.5 & 48.6 & 50.0 & 50.4 & 50.7 & 48.2 & 49.0 & 49.0 & 48.2 & 50.6 & 50.1 & 48.0 & 47.2 & 47.5 & 47.2 & 48.8 & 49.2 & 48.9 \\
\hline $\mathrm{TiO}_{2}$ & 1.09 & 1.05 & 1.07 & 1.00 & 0.99 & 1.05 & 1.44 & 1.42 & 1.41 & 1.27 & 1.12 & 1.10 & 1.14 & 1.13 & 1.16 & 1.05 & 0.83 & 0.91 & 0.87 & 1.01 & 0.94 & 0.92 \\
\hline $\mathrm{Al}_{2} \mathrm{O}_{3}$ & 16.4 & 16.3 & 16.3 & 15.9 & 15.4 & 16.1 & 14.2 & 14.3 & 14.6 & 15.3 & 14.8 & 15.1 & 14.7 & 14.5 & 14.7 & 14.8 & 15.7 & 16.9 & 17.0 & 15.3 & 15.7 & 15.1 \\
\hline $\mathrm{tFe}_{2} \mathrm{O}_{3} \mathrm{a}$ & 10.76 & 10.61 & 10.69 & 10.50 & 9.95 & 10.42 & 11.12 & 10.26 & 10.35 & 12.45 & 11.36 & 11.01 & 11.54 & 10.20 & 10.50 & 11.07 & 9.68 & 10.13 & 10.00 & 10.59 & 9.95 & 10.24 \\
\hline $\mathrm{MnO}$ & 0.19 & 0.19 & 0.19 & 0.18 & 0.16 & 0.16 & 0.17 & 0.17 & 0.15 & 0.13 & 0.16 & 0.16 & 0.16 & 0.18 & 0.17 & 0.18 & 0.16 & 0.19 & 0.17 & 0.17 & 0.17 & 0.17 \\
\hline $\mathrm{MgO}$ & 76 & 6.71 & 6.78 & 8.82 & 8.63 & 7.02 & 7.67 & 8.08 & 8.24 & 5.72 & 6.86 & 7.06 & & 9.13 & 9.32 & 6.86 & 11.61 & 7.4 & & 7.51 & & 8.08 \\
\hline $\mathrm{CaO}$ & 12.19 & 11.51 & 12.41 & 10.96 & 11.96 & 12.22 & 11.37 & 11.86 & 12.01 & 11.10 & 12.38 & 12.11 & 12.85 & 12.07 & 11.52 & 12.66 & 11.67 & 12.20 & 11.70 & 12.17 & 12.44 & 13.13 \\
\hline & & & & & 2.48 & 2.77 & 2.66 & 2.6 & 2.67 & 2. & 2. & 2. & 2. & 2.67 & 2.6 & 2.3 & 2.34 & 2. & 2.5 & 2. & 2. & 2.27 \\
\hline $\mathrm{K}_{2} \mathrm{O}$ & 0.45 & 0.50 & 0.39 & 0.38 & 0.51 & 0.45 & 0.41 & 0.57 & 0.39 & 1.12 & 0.64 & 0.57 & 0.99 & 0.06 & 0.06 & 0.59 & 0.05 & 0.58 & 0.46 & 1.03 & 0.44 & 0.57 \\
\hline $\mathrm{P}_{2} \mathrm{O}_{5}$ & 0.07 & 0.08 & 0.07 & 0.07 & 0.08 & 0.07 & 0.10 & 0.10 & 0.11 & 0.11 & 0.09 & 0.08 & 0.19 & 0.08 & 0.08 & 0.08 & 0.05 & 0.05 & 0.05 & 0.11 & 0.08 & 0.09 \\
\hline Total & 98.12 & 97,46 & 99.45 & 98.29 & 97.74 & 98.90 & 99.11 & 99.84 & 100.62 & 97.87 & 98.84 & 98.76 & 98.26 & 100.69 & 100.32 & 97.60 & 99.29 & 98.44 & 98.48 & 99.80 & 99.77 & 98.37 \\
\hline & & & & & & & & & & & & & & & & & & & & & & \\
\hline & 8.52 & 8.41 & 8.47 & 8.32 & 7.88 & 8.25 & 8.81 & 8.13 & 8.20 & 9.86 & 9.00 & 8.72 & 9.14 & 8.08 & 8.32 & 8.77 & 7.67 & 8.02 & 7.92 & 8.39 & 7.88 & 8.11 \\
\hline
\end{tabular}

Trace Elements (ppm)

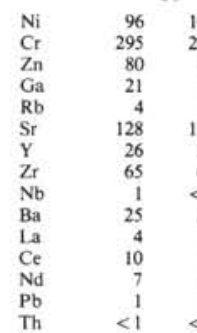

$\begin{array}{rr}104 & 108 \\ 278 & 294 \\ 81 & 69 \\ 19 & 14 \\ 4 & 4 \\ 130 & 126 \\ 25 & 25 \\ 65 & 64 \\ <1 & 1 \\ 30 & 29 \\ 5 & 5 \\ 11 & 7 \\ 8 & 7 \\ 4 & 3 \\ <1 & <1\end{array}$

$\begin{array}{rrr}129 & 163 & 126 \\ 298 & 274 & 300 \\ 94 & 72 & 63 \\ 18 & 20 & 19 \\ 6 & 5 & 4 \\ 127 & 127 & 139 \\ 25 & 25 & 26 \\ 64 & 62 & 67 \\ <1 & <1 & <1 \\ 18 & 28 & 16 \\ 2 & 4 & 4 \\ 12 & 8 & 5 \\ 8 & 7 & 6 \\ <1 & <1 & 5 \\ <1 & <1 & 1\end{array}$

$\begin{array}{rr}126 & 78 \\ 300 & 162 \\ 63 & 86 \\ 19 & 18 \\ 4 & 8 \\ 139 & 87 \\ 26 & 35 \\ 67 & 70 \\ <1 & 2 \\ 16 & 25 \\ 4 & 3 \\ 5 & 10 \\ 6 & 8 \\ 5 & 3 \\ 1 & 1\end{array}$

$\begin{array}{rr}152 & 159 \\ 163 & 175 \\ 89 & 82 \\ 16 & 18 \\ 4 & 6 \\ 85 & 85 \\ 37 & 35 \\ 69 & 68 \\ 1 & <1 \\ 13 & 26 \\ 4 & 4 \\ 11 & 8 \\ 9 & 9 \\ 4 & 5 \\ <1 & <1\end{array}$

$\begin{array}{rrrr}125 & 91 & 97 & 1 \\ 296 & 276 & 260 & 276 \\ 105 & 87 & 98 & \\ 19 & 19 & 19 & \\ 10 & 5 & 5 & \\ 83 & 73 & 73 & \\ 37 & 28 & 29 & \\ 59 & 54 & 53 & \\ <1 & <1 & <1 \\ 32 & 20 & 24 & \\ 7 & 4 & 5 & \\ 8 & 8 & 8 & \\ 8 & 6 & 7 & \\ 3 & 1 & 6 & \\ <1 & <1 & 2 & \end{array}$

$\begin{array}{rrr}113 & 143 & 112 \\ 276 & 253 & 226 \\ 94 & 69 & 70 \\ 20 & 17 & 17 \\ 9 & <1 & <1 \\ 78 & 69 & 69 \\ 30 & 26 & 27 \\ 54 & 51 & 54 \\ 1 & 1 & <1 \\ 25 & 22 & 21 \\ 3 & 3 & 4 \\ 6 & 6 & 7 \\ 7 & 6 & 6 \\ 3 & 2 & 4 \\ 1 & <1 & <1\end{array}$

$\begin{array}{rr}107 & 193 \\ 279 & 269 \\ 102 & 5 \\ 18 & 15 \\ 5 & < \\ 71 & 107 \\ 29 & 20 \\ 49 & 53 \\ <1 & < \\ 24 & 13 \\ 4 & \\ 4 & \\ 6 & \\ 3 & \\ <1 & \end{array}$

$\begin{array}{rrr}193 & 132 & 164 \\ 269 & 295 & 269 \\ 53 & 101 & 69 \\ 15 & 13 & 14 \\ <1 & 6 & 6 \\ 107 & 116 & 109 \\ 20 & 22 & 23 \\ 53 & 60 & 58 \\ <1 & <1 & <1 \\ 13 & 22 & 14 \\ 3 & 4 & 3 \\ 3 & 6 & 6 \\ 5 & 6 & 5 \\ 5 & <1 & 2 \\ 1 & <1 & <1\end{array}$

$\begin{array}{rrr}131 & 145 & 139 \\ 392 & 372 & 370 \\ 118 & 80 & 82 \\ 20 & 18 & 18 \\ 9 & 4 & 5 \\ 87 & 86 & 88 \\ 29 & 22 & 22 \\ 48 & 47 & 47 \\ 1 & 2 & 2 \\ 18 & 20 & 16 \\ 5 & 6 & 4 \\ 10 & 6 & 9 \\ 7 & 7 & 7 \\ 4 & 2 & 5 \\ <1 & <1 & <1\end{array}$

$\begin{array}{lrrrrr}\text { CIPW Norm } & & & & \\ \mathrm{Q} & 0.0 & 0.0 & 0.0 & 0.0 & 0.0 \\ \mathrm{Or} & 2.7 & 3.0 & 2.3 & 2.3 & 3.1 \\ \mathrm{Ab} & 22.3 & 23.9 & 23.1 & 23.1 & 20.8 \\ \mathrm{An} & 32.2 & 31.4 & 30.8 & 30.9 & 30.2 \\ \mathrm{Ne} & 0.1 & 0.0 & 0.6 & 0.0 & 0.4 \\ \mathrm{Di} & 23.8 & 21.9 & 25.2 & 19.8 & 24.4 \\ \mathrm{Hy} & 0.0 & 0.9 & 10.0 & 1.4 & 0.0 \\ \mathrm{Ol} & 13.8 & 13.8 & 13.0 & 17.8 & 16.4 \\ \mathrm{Mt} & 1.9 & 1.9 & 1.9 & 1.9 & 1.8 \\ \mathrm{IIm} & 2.1 & 2.0 & 2.0 & 1.9 & 1.9 \\ \mathrm{Ap} & 0.2 & 0.2 & 0.2 & 0.1 & 0.2 \\ & & & & & \\ \text { Unit } & \mathrm{L} 1 \mathrm{~b} & \text { LIc } & \text { L.1d } & \text { L.1d } & \text { L.2 }\end{array}$

$\begin{array}{rrr}0.0 & 0.0 & 0.0 \\ 2.7 & 2.5 & 3.4 \\ 23.6 & 22.7 & 22.7 \\ 30.5 & 25.8 & 25.4 \\ 0.0 & 0.0 & 0.0 \\ 24.9 & 25.1 & 26.8 \\ 0.0 & 12.7 & 8.4 \\ 13.4 & 5.4 & 7.7 \\ 1.8 & 1.9 & 1.8 \\ 2.0 & 2.8 & 2.7 \\ 0.2 & 0.2 & 0.2 \\ L .2 & L .3 a & L .3 a\end{array}$

\begin{tabular}{rrr}
0.0 & 0.0 \\
2.3 & 6.8 & 0.0 \\
22.5 & 20.8 & 20.6 \\
26.4 & 28.3 & 28.2 \\
0.0 & 0.0 & \\
26.2 & 22.6 & 2.0 \\
10.4 & 6.5 & \\
6.7 & 9.0 \\
1.8 & 2.2 \\
2.7 & 2.5 \\
0.2 & 0.3 \\
\hline L. & L.3b &
\end{tabular}

$\begin{array}{rrrr}0.0 & 0.0 & 0.0 & 0.0 \\ 3.8 & 3.4 & 5.9 & 0.4 \\ 20.6 & 22.0 & 19.3 & 22.4 \\ 28.2 & 28.4 & 27.8 & 27.3 \\ 0.0 & 0.0 & 0.0 & 0.0 \\ 27.4 & 26.1 & 29.6 & 25.7 \\ 5.9 & 4.6 & 1.7 & 11.1 \\ 8.7 & 10.2 & 10.0 & 8.1 \\ 2.0 & 1.9 & 2.0 & 1.8 \\ 2.2 & 2.1 & 2.2 & 2.1 \\ 0.2 & 0.2 & 0.5 & 0.2 \\ \mathrm{~L} 3 \mathrm{c} & \mathrm{L} 3 \mathrm{C} & \mathrm{L} \text {. } \mathrm{d} & \mathrm{L} 3 \mathrm{~d}\end{array}$

$\begin{array}{rrr}0.0 & 0.0 & \\ 0.4 & 3.6 & \\ 22.6 & 20.5 & 19.7 \\ 27.9 & 28.6 & 32.4 \\ 0.0 & 0.0 & \\ 23.2 & 28.9 & 20.7 \\ 11.2 & 2.2 & 0.0 \\ 9.6 & 11.0 & 22.6 \\ 1.8 & 2.0 & \\ 2.2 & 2.0 & \\ 0.2 & 0.2 & 0.1\end{array}$

$\begin{array}{rr}0.0 & 0.0 \\ 0.3 & 3.5 \\ 19.7 & 19.7 \\ 32.4 & 33.7 \\ 0.1 & 1.1 \\ 20.7 & 22.5 \\ 0.0 & 0.0 \\ 22.6 & 15.1 \\ 1.7 & 1.8 \\ 1.6 & 1.8 \\ 0.1 & 0.1\end{array}$

$\begin{array}{rrrr}0.0 & 0.0 & 0.0 & 0.0 \\ 2.7 & 6.2 & 2.6 & 3.4 \\ 20.2 & 18.6 & 19.6 & 19.3 \\ 34.3 & 29.2 & 31.2 & 29.4 \\ 0.7 & 0.0 & 0.0 & 0.0 \\ 19.8 & 25.5 & 24.5 & 29.0 \\ 0.0 & 4.6 & 6.3 & 1.8 \\ 17.8 & 11.0 & 11.2 & 12.4 \\ 1.8 & 1.9 & 1.7 & 1.8 \\ 1.7 & 1.9 & 1.8 & 1.8 \\ 0.1 & 0.3 & 0.2 & 0.2\end{array}$

Note: Samples A through $\mathrm{M}$ are the 13 samples that had become separated from their labelled capsules, so it is not known to which intervals they correspond.

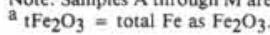

normative. These diagrams shows that basalts from Units $\mathrm{C} 1$ and $\mathrm{C} 4$ are less silica saturated than those from Units C2, C3, and C5. Glass compositions are plotted on the same diagram, and these also are either Ol-normative (Units C1, C4) or Qz-normative (Units C2, C3, C5). In the Px-Ol-Pl projection (Fig. 9), the whole-rock data all fall in the olivine-tholeiite field of Miyashiro (1970). Unit C1 and C4 basalts, however, are more Olnormative than those from Units $\mathrm{C} 2, \mathrm{C} 3$, or C5. The Hy-normative glasses of Units $\mathrm{C} 1$ and $\mathrm{C} 4$ basalts lie on the 1 bar plagioclase-olivine cotectic curve (Miyashiro, 1970). Thus the two magma types also follow two different major-element fractionation trends, namely, a $\mathrm{Si}-\mathrm{Ca}$ poor and $\mathrm{Al}-\mathrm{Na}$ rich trend (Units $\mathrm{C} 1$ and $\mathrm{C} 4$ ) and a Si-Ca rich and $\mathrm{Al}-\mathrm{Na}$ poor trend (Units $\mathrm{C} 2, \mathrm{C} 3$, and C5).

The behavior of the compatible trace elements $\mathrm{Ni}$, $\mathrm{Cr}$, and $\mathrm{Sr}$ relative to $\mathrm{HYG}$ elements such as $\mathrm{Ti}, \mathrm{Zr}, \mathrm{Y}$, and $\mathrm{P}$ also discriminates between the two magma types. To illustrate these relationships, each element is plotted against $\mathrm{Zr}$ in Figures 10, 11, and 12. Although Ni contents vary considerably within each chemical unit, a broad negative correlation is observed with $\mathrm{Zr}$ for both magma types (Fig. 10). It is difficult to distinguish between the two magma types on the basis of absolute $\mathrm{Ni}$ contents, because each has a similar range (100-160 $\mathrm{ppm}$, averaging $140 \mathrm{ppm}$ ), which is within that of typical depleted MORB (e.g., Nazca plate, Rhodes et al., 1976). The behavior of $\mathrm{Cr}$, however, is rather different. Cr shows a progressive depletion from Units C5 $(\sim 400 \mathrm{ppm})$ through $\mathrm{C} 3(\sim 250 \mathrm{ppm})$ to $\mathrm{C} 2(\sim 175$ $\mathrm{ppm})$. In contrast, $\mathrm{Cr}$ shows a small but significant increase between Units C4 (278 ppm) and C1 (289 ppm) (Fig. 11, Table 5).

The variation of $\mathrm{Sr}$ relative to $\mathrm{Zr}$ (Fig. 12) also characterizes each magma type. The $\mathrm{Sr}$ contents of Units $C 1$ and C4 are relatively high $(100-140 \mathrm{ppm}$, Table 5) and increase sympathetically with $\mathrm{Zr}$, with the $\mathrm{Sr} / \mathrm{Zr}$ ratio remaining constant at about 2 . Sr contents of Units C2, C3, and C5 are lower (60-90 ppm) and remain approximately constant with increasing $\mathrm{Zr}$. Within each chemical unit, however, $\mathrm{Sr}$ rises with $\mathrm{Zr}$, and each unit is defined by a unique $\mathrm{Sr} / \mathrm{Zr}$ ratio.

Both magma types have similar ranges of $\mathrm{Rb}$ and $\mathrm{Ba}$ and average approximately 5 and $20 \mathrm{ppm}$, respectively. Neither of these elements show any correlation with $\mathrm{Zr}$, and each element displays a considerable range within a chemical unit. Both elements are notably susceptible to seawater alteration, which probably accounts for much of the scatter. Similarly, Nb shows no discernible correlation with $\mathrm{Zr}$, which varies from 3 to $7 \mathrm{ppm}$. The cause of the scatter here is more likely the result of analytical imprecision at such low abundances. However, $\mathrm{Zr} / \mathrm{Nb}$ ratios for these basalts are relatively high, 
Table 4. (Continued).

\begin{tabular}{|c|c|c|c|c|c|c|c|c|c|c|c|c|c|c|c|c|c|c|c|c|c|c|}
\hline $\begin{array}{r}29 \\
3 \\
31\end{array}$ & $\begin{array}{r}29 \\
4 \\
86\end{array}$ & $\begin{array}{l}30 \\
1 \\
55\end{array}$ & $\begin{array}{r}30 \\
4 \\
91\end{array}$ & $\begin{array}{r}32 \\
1 \\
107\end{array}$ & $\begin{array}{r}34 \\
2 \\
119\end{array}$ & $\begin{array}{r}36 \\
2 \\
4\end{array}$ & $\begin{array}{r}36 \\
3 \\
62\end{array}$ & $\begin{array}{c}36 \\
5 \\
29\end{array}$ & $\begin{array}{r}37 \\
1 \\
80\end{array}$ & A & B & c & D & E & $\mathrm{F}$ & G & $\mathrm{H}$ & 1 & $J$ & K & L. & M \\
\hline 48.6 & 48.7 & 48.6 & 49.4 & 49.0 & 48,7 & 48.5 & 47.8 & 48.1 & 47.7 & 50.2 & 50.0 & 46.9 & 48.6 & 48.6 & 47.8 & 49.2 & 48.2 & & 48.7 & & & \\
\hline 0.95 & 0.93 & 0.89 & 0.89 & 0.79 & 0.90 & 0.87 & 0.98 & 0.90 & 0.92 & 1.16 & 1.38 & 0.83 & 1.10 & 0.93 & 1.04 & 1.13 & $\begin{array}{r}40.2 \\
0.90\end{array}$ & 0.82 & 0.86 & 1.11 & 1.15 & 0.83 \\
\hline 15.6 & 15.3 & 14.9 & 15.2 & 15.8 & 16.2 & 16.0 & 16.0 & 15.6 & 15.9 & 15.0 & 14.5 & 15.2 & 15.7 & 17.7 & 15.7 & 14.2 & 15.5 & 15.2 & 15.8 & 14.4 & 14.9 & 17.7 \\
\hline 10.26 & 9.82 & 9.92 & 9.66 & 9.50 & 10.49 & 10.10 & 11.24 & 10.56 & 10.75 & 10.41 & 10.84 & 10.65 & 10.42 & 10.25 & 10.59 & 11.40 & 10.60 & 9.98 & 10.36 & 10.92 & 10.93 & 10.22 \\
\hline 0.16 & 0,16 & 0.16 & 0.16 & 0.17 & 0.17 & 0.18 & 0.17 & 0.16 & 0.17 & 0.17 & 0.18 & 0.16 & 0.22 & 0.18 & 0.20 & 0.17 & 0.18 & 0.15 & 0.16 & 0.18 & 0.17 & 0.18 \\
\hline 6.57 & 8.04 & 8.13 & 9.23 & 8.63 & 6.86 & 7.58 & 6.63 & 7.04 & 6.10 & 8.01 & 7.43 & 12.64 & 7.84 & 5.26 & 6.44 & 7.50 & 7.53 & 7.89 & 7.65 & 8.52 & 7.98 & 8.10 \\
\hline 12.69 & 12.94 & 13.89 & 12.66 & 13.31 & 12.91 & 12.47 & 11.47 & 13.07 & 12.64 & 12.27 & 11.83 & 10.93 & 12.05 & 11.18 & 13.86 & 12.54 & 13.44 & 12.84 & 11.17 & 11.78 & 12.17 & 11.36 \\
\hline 2.21 & 2.29 & 2.15 & 2.37 & 2.12 & 2.32 & 2.36 & 2.24 & 2.25 & 2.15 & 2.70 & 2.63 & 2.24 & 2.59 & 2.80 & 2.70 & 2.50 & 2.27 & 2.17 & 2.16 & 2.63 & 2.51 & 2.61 \\
\hline 1.14 & 0.53 & 0.62 & 0.48 & 0.34 & 0.58 & 0.53 & 1.12 & 0.59 & 1.14 & 0.35 & 0.46 & 0.05 & 0.57 & 1.47 & 0.40 & 0.51 & 0.45 & 0.79 & 1.19 & 0.22 & 0.40 & 0.51 \\
\hline 0.10 & 0.09 & 0.09 & 0.07 & 0.05 & 0.07 & 0.07 & 0.06 & 0.06 & 0.09 & 0.08 & 0.11 & 0.05 & 0.07 & 0.06 & 0.07 & 0.09 & 0.06 & 0.08 & 0.07 & 0.08 & 0.07 & 0.05 \\
\hline 98.31 & 99.82 & 99.38 & 100.06 & 99.71 & 99.21 & 98.63 & 97,78 & 98.27 & 97.57 & 100.32 & 99.31 & 99.62 & 99.12 & 98.45 & 98.82 & 99.32 & 99.11 & 98.3 & 98.18 & 99.60 & 99.97 & 98.61 \\
\hline 1.23 & 1.18 & 1.19 & 1.16 & 1.14 & 1.26 & 1.21 & 1.35 & 1.27 & 1.29 & 1.25 & 1.30 & 1.16 & 1.25 & 1.23 & 1.27 & 1.37 & 1.27 & 1.20 & 1.24 & 1.31 & 1.31 & 1.23 \\
\hline 8.13 & 7.78 & 7.86 & 7.65 & 7.52 & 8.31 & 8.00 & 8.90 & 8.36 & 8.51 & 8.24 & 8.59 & 8.54 & 8.25 & 8.12 & 8.39 & 9.03 & 8.40 & 7.90 & 8.21 & 8.65 & 8.66 & 8.09 \\
\hline 125 & 140 & 150 & 153 & 123 & 108 & 148 & 155 & 161 & 170 & 186 & 96 & 246 & 120 & 103 & 107 & 102 & 133 & 127 & 122 & 121 & 149 & 157 \\
\hline 384 & 358 & 375 & 365 & 367 & 393 & 390 & 416 & 402 & 394 & 248 & 173 & 324 & 316 & 304 & 284 & 270 & 414 & 398 & 479 & 247 & 245 & 303 \\
\hline 85 & 73 & 71 & 62 & 59 & 107 & 89 & 76 & 80 & 79 & 72 & 84 & 44 & 123 & 99 & 72 & 82 & 74 & 69 & $\begin{array}{l}74 \\
18\end{array}$ & 72 & 71 & 86 \\
\hline 16 & 17 & 15 & 18 & 17 & 19 & 16 & 15 & 19 & 17 & 15 & 19 & 17 & 18 & 18 & 18 & 17 & 18 & 17 & 18 & 15 & 17 & 19 \\
\hline 13 & ${ }_{0<}^{5}$ & 5 & 4 & 2 & 5 & 6 & 7 & 4 & 8 & 4 & 6 & $<1$ & 5 & 12 & 4 & 7 & 3 & ${ }^{8}$ & 14 & 5 & $7^{5}$ & 6 \\
\hline 90 & 85 & 92 & 87 & 73 & 93 & 90 & 94 & 92 & 93 & 72 & 86 & 101 & 132 & 122 & 128 & 75 & 90 & 74 & 77 & 71 & 72 & 109 \\
\hline $\begin{array}{l}288 \\
47\end{array}$ & $\begin{array}{l}21 \\
45\end{array}$ & 22 & 21 & 20 & 25 & 24 & 24 & 22 & 25 & 29 & 34 & 20 & 27 & 23 & 25 & 28 & 21 & $\begin{array}{r}23 \\
23\end{array}$ & 21 & 27 & 28 & 22 \\
\hline $\begin{array}{l}47 \\
<1\end{array}$ & 45 & 46 & 48 & 37 & 45 & 43 & 45 & 43 & 45 & 55 & 61 & so & 66 & 54 & 61 & 55 & 47 & 39 & 40 & 52 & 51 & 52 \\
\hline $\begin{array}{l}<1 \\
31\end{array}$ & $\begin{array}{l}1 \\
16\end{array}$ & $\begin{array}{l}1 \\
19\end{array}$ & ${ }_{13}^{2}$ & $\begin{array}{l}<1 \\
14\end{array}$ & $<1$ & $<1$ & 1 & $<1$ & $<1$ & $<1$ & $<1$ & $<!$ & $<1$ & $\begin{array}{l}<1 \\
20\end{array}$ & 1 & 1 & $\begin{array}{l}<1 \\
17\end{array}$ & $\begin{array}{l}<1 \\
16\end{array}$ & $\begin{array}{l}<1 \\
20\end{array}$ & ${ }_{15}^{1}$ & $\begin{array}{l}1 \\
23\end{array}$ & $\begin{array}{l}<1 \\
12\end{array}$ \\
\hline 5 & $\begin{array}{r}16 \\
3 \\
3\end{array}$ & $\begin{array}{r}19 \\
3\end{array}$ & $\begin{array}{r}13 \\
4\end{array}$ & $\begin{array}{r}14 \\
3\end{array}$ & $\begin{array}{r}19 \\
5\end{array}$ & $\begin{array}{r}24 \\
2\end{array}$ & $\begin{array}{c}16 \\
4\end{array}$ & $\begin{array}{l}8 \\
3\end{array}$ & $\begin{array}{r}25 \\
3\end{array}$ & $\begin{array}{r}19 \\
4\end{array}$ & $\begin{array}{r}25 \\
5\end{array}$ & $\begin{array}{l}5 \\
2\end{array}$ & 20 & $\begin{array}{r}29 \\
4\end{array}$ & $\begin{array}{c}18 \\
3\end{array}$ & $\begin{array}{r}15 \\
2\end{array}$ & $\begin{array}{r}17 \\
3\end{array}$ & $\begin{array}{r}16 \\
1\end{array}$ & ${ }_{3}^{20}$ & 4 & $\begin{array}{r}23 \\
3\end{array}$ & 12 \\
\hline 7 & 9 & 7 & 6 & 4 & $\frac{5}{7}$ & $\frac{2}{7}$ & 8 & 5 & 4 & 6 & 10 & ${ }_{10}^{2}$ & 11 & $\begin{array}{l}4 \\
7\end{array}$ & $\begin{array}{l}3 \\
8\end{array}$ & $1_{11}^{2}$ & 8 & 6 & 4 & 7 & 6 & 8 \\
\hline 6 & 6 & 7 & 6 & 5 & 5 & 5 & 6 & 4 & 5 & 6 & 9 & 7 & 8 & 6 & 7 & 7 & 5 & 4 & 4 & 7 & 5 & $\begin{array}{l}8 \\
6\end{array}$ \\
\hline & 3 & 3 & 4 & 4 & 3 & $<i$ & i & 6 & 2 & 6 & 2 & 2 & 4 & 2 & 4 & 4 & 1 & $<1$ & 1 & $i$ & 4 & 2 \\
\hline$<1$ & 2 & $<1$ & $<1$ & $<1$ & $<1$ & 1 & 2 & $<1$ & $<1$ & 1 & $<1$ & $<1$ & $<1$ & $<1$ & $<1$ & $<1$ & 1 & $<1$ & 2 & $<1$ & $<1$ & $<1$ \\
\hline 0.0 & & & & & & 0. & & & & & & & & & & & & & & 0.0 & 0.0 & 0.0 \\
\hline $\begin{array}{l}0.0 \\
6.9\end{array}$ & $\begin{array}{l}0.0 \\
3.2\end{array}$ & 3. & 2 & $\begin{array}{l}0.0 \\
2.0\end{array}$ & 3 & $\begin{array}{l}0.0 \\
3.1\end{array}$ & $\begin{array}{l}0.0 \\
6.8\end{array}$ & $\begin{array}{l}0.0 \\
3.5\end{array}$ & $\begin{array}{l}0.0 \\
6.9\end{array}$ & $\begin{array}{l}0.0 \\
2.1\end{array}$ & $\begin{array}{l}0.0 \\
2.7\end{array}$ & 0 & $\begin{array}{l}0.0 \\
3.4\end{array}$ & $\begin{array}{l}0.0 \\
8.8\end{array}$ & $\begin{array}{l}0.0 \\
2.4\end{array}$ & & 2.7 & 4.8 & 7.2 & 1.3 & 2.4 & 3.0 \\
\hline 19.0 & 19.6 & 17.3 & 20 & $\begin{array}{r}2.00 \\
18.0\end{array}$ & 19.8 & 20.2 & $\begin{array}{l}6.8 \\
19.4\end{array}$ & $\begin{array}{l}3.3 \\
9.4\end{array}$ & $\begin{array}{l}6.9 \\
18.3\end{array}$ & 22.8 & 22.4 & $\begin{array}{l}19.3 \\
19.0\end{array}$ & 22.1 & $\begin{array}{r}8.6 \\
21.0\end{array}$ & 17.7 & 21.3 & 18.9 & 18.7 & 18.6 & 22.3 & 21.2 & 20.3 \\
\hline 29.7 & 30. & 29. & 29 & 32.7 & 32.4 & 31.9 & 31.1 & 31.2 & 31.2 & 27.7 & 26.5 & 31.4 & 29.7 & 32.0 & 29.9 & 26.3 & 31.1 & 29.8 & 30.5 & 27.0 & 28.3 & 35.5 \\
\hline 0.0 & 0. & 0 & & 0.0 & & 0.0 & 0 & 0.0 & 0.2 & 0.0 & 0.0 & 0.0 & 0.0 & 1.7 & 2.9 & 0.0 & 0.2 & 0.0 & & 0 & 0.0 & 1.1 \\
\hline 27.6 & 27.8 & 32. & 26 & 27 & 26 & 24.8 & 22.0 & 28.2 & 26 & 26.5 & & 18. & 24 & 19 & 32. & 29.2 & 29 & 28.1 & 20.8 & 25.4 & 25.8 & 17.4 \\
\hline 1.2 & 3.0 & 0 & 2 & 5.3 & 3 & 3.6 & 3.1 & 1.3 & 0 & 6. & 10.6 & 0 & 0 & 0 & 0 & 4 & 0 & & & & 7.8 & 0.0 \\
\hline 10.8 & 11.6 & 12.5 & 13.9 & 10.9 & 10.6 & 11.8 & 12.6 & 11.8 & 11.8 & 9.4 & 5.9 & 25.7 & 14.4 & 12. & 9.9 & 10.2 & 13.1 & 12.6 & 11.0 & 9.3 & 9.3 & 18.2 \\
\hline 1.8 & 1.7 & 1.7 & 1.7 & 1.7 & 1.8 & 1.8 & 2.0 & 1.9 & 1.9 & 1.8 & 1.9 & 1. & 1.8 & 1. & 1.9 & 2.0 & 1. & 1.8 & 1. & 9 & 1.9 & 1.8 \\
\hline $\begin{array}{l}1.8 \\
0.3\end{array}$ & 1.8 & 1.7 & 1.7 & 1.5 & 1.7 & 1.7 & 1.9 & 1.7 & 1.8 & 2.2 & 2.6 & 1.6 & 2.1 & 1.8 & 2.0 & 2.2 & 1.7 & 1.6 & 1.7 & 2.1 & 2.2 & 1.6 \\
\hline 0.3 & 0.2 & 0.2 & 0.2 & 0.1 & 0.2 & 0.2 & 0.1 & 0.1 & 0.2 & 0.2 & 0.3 & 0.1 & 0.2 & 0.1 & 0.2 & 0.2 & 0.1 & 0.2 & 0.2 & 0.2 & 0.2 & 0.1 \\
\hline L6b & L6b & LLC & $\mathrm{L} 6 \mathrm{~d}$ & Loc & $L \theta x$ & Lof & L6 & L6 & & & & & & & & & & & & & & \\
\hline CS & CS & C & 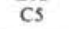 & C5 & C5 & C5 & C5 & CS & Cs & & & & & & & & & & & & & \\
\hline
\end{tabular}

ranging from 10 to 30 , and fall in the range of values for depleted N-type MORB (Erlank and Kable, 1976; Tarney et al., 1979, Sun et al., 1979). The HYG elements $\mathrm{La}, \mathrm{Ce}, \mathrm{Nd}, \mathrm{Pb}$, and $\mathrm{Th}$ are present in very low abundances (Tables 4,5 ), typical of depleted N-type MORB.

\section{Holes 449 and 450}

Because of the poor basement penetration and recovery at these two Parece Vela Basin sites, the available data are limited to only four whole-rock analyses. These are compared in Table 6 with the average glass analyses from each hole. The basalts from Hole 449 and 450 are rather similar in terms of $\mathrm{MgO}(\sim 7.5 \%), \mathrm{FeO} /(\mathrm{FeO}+$ $\mathrm{MgO}$ ) ratio $(\sim 0.52)$, and $\mathrm{Ni}$ contents $(\sim 110 \mathrm{ppm})$, but the basalt from Hole 450 is slightly richer in $\mathrm{CaO}$ and has a slightly higher $\mathrm{CaO} / \mathrm{Al}_{2} \mathrm{O}_{3}$ ratio. $\mathrm{K}_{2} \mathrm{O}$ in the whole-rock samples is again enriched relative to the values in the glasses (and in fresh MORB), but the difference is not so marked as at Hole 447A. Small but significant differences between the two holes are apparent for several incompatible elements. For instance, basalts from Hole 450 have higher $\mathrm{TiO}_{2}, \mathrm{Y}, \mathrm{Zr}$, and $\mathrm{Ce}$ but lower $\mathrm{Sr}, \mathrm{Ba}$ (and $\mathrm{K}_{2} \mathrm{O}$ ) than those from Hole 449 . Figures 3, 5, and 6 also suggest that the basalts from Holes 449 and 450 have parental magma compositions broadly similar to those of Units $\mathrm{C} 1$ and $\mathrm{C} 4$ from Hole $447 \mathrm{~A}$ in the Philippine Sea. In overall geochemical characteristics, the Parece Vela basalts are not very different from typical mid-ocean ridge basalts.

\section{Mineral Chemistry}

The composition of phenocrysts found in fresh glasses from Holes $447 \mathrm{~A}, 449$, and 450 have been studied using the electron microprobe. The number of analyses of each phase varied in accordance with its abundance; thus a total of 300 plagioclase crystals, 100 olivine crystals, 80 pyroxene crystals, and 50 chromespinels were analyzed. Included in this investigation were many examples of xenocrysts-crystals of plagioclase, olivine, pyroxene, and spinel-in marked disequilibrium with their host glasses. We particularly emphasized recognition of compositional differences between the phenocrysts and the resorbed phases in order to place constraints on their possible modes of origin.

\section{Plagioclase}

Plagioclase phenocrysts are ubiquitous in Leg 59 basalts; their compositional ranges are summarized in Figure 13. The phenocrysts are characterized by oscillatory zoning; within each sample studied, core compositions vary by 10 to $15 \mathrm{~mol} \mathrm{\%}$ of anorthite. General directions of zoning are indicated in Figure 13. The majority of phenocryst compositions fall in the range $\mathrm{An}_{90}$ to $\mathrm{An}_{80}$, but glomerophyric plagioclases (often associ- 
Table 5. Representative analyses of basalts and glasses from Chemical Units C1 through C5, Hole 447A.

\begin{tabular}{|c|c|c|c|c|c|c|c|c|c|c|}
\hline \multirow[b]{2}{*}{ Unit } & \multicolumn{2}{|c|}{$\mathrm{Cl}$} & \multicolumn{2}{|c|}{$\mathrm{C} 2$} & \multicolumn{2}{|c|}{ C3 } & \multicolumn{2}{|c|}{$\mathrm{C} 4$} & \multicolumn{2}{|c|}{ C5 } \\
\hline & $\mathrm{wr}^{\mathrm{a}}$ & $\mathrm{glb}^{\mathrm{b}}$ & wr & gl & wr & g1 & wr & gl & wr & gl \\
\hline $\mathrm{SiO}_{2}$ & 47.9 & 49.7 & 50.4 & 52.0 & 49.0 & 51.3 & 47.3 & 49.2 & 48.6 & 51.1 \\
\hline $\mathrm{TiO}_{2}$ & 1.04 & 0.99 & 1.42 & 1.30 & 1.14 & 1.04 & 0.87 & 0.74 & 0.92 & 0.84 \\
\hline $\mathrm{Al}_{2} \mathrm{O}_{3}$ & 16.0 & 16.3 & 14.4 & 14.2 & 14.9 & 14.9 & 16.5 & 17.4 & 15.6 & 15.5 \\
\hline $\mathrm{tFeO}^{\circ}$ & 9.40 & 9.08 & 9.52 & 10.07 & 8.94 & 9.75 & 8.94 & 8.26 & 9.22 & 8.79 \\
\hline $\mathrm{MnO}$ & 0.18 & 0.11 & 0.16 & 0.15 & 0.16 & 0.13 & 0.17 & 0.11 & 0.17 & 0.11 \\
\hline $\mathrm{MgO}$ & 7.59 & 8.19 & 8.00 & 7.07 & 7.30 & 7.99 & 9.19 & 9.09 & 7.61 & 8.48 \\
\hline $\mathrm{CaO}$ & 11.77 & 11.92 & 11.74 & 11.46 & 12.10 & 12.27 & 11.86 & 12.40 & 12.77 & 12.69 \\
\hline $\mathrm{Na}_{2} \mathrm{O}$ & 2.66 & 2.38 & 2.67 & 2.30 & 2.48 & 1.87 & 2.45 & 2.21 & 2.23 & 1.76 \\
\hline $\mathrm{K}_{2} \mathrm{O}$ & 0.46 & 0.02 & 0.46 & 0.02 & 0.58 & - & 0.36 & - & 0.72 & 0.02 \\
\hline $\mathrm{P}_{2} \mathrm{O}_{5}$ & 0.06 & - & 0.09 & 0.05 & 0.10 & - & 0.05 & - & 0.08 & - \\
\hline
\end{tabular}

Trace Elements (ppm)

$\begin{array}{lrr}\mathrm{Cr} & 289 & 16 \\ \mathrm{Ni} & 124 & 129 \\ \mathrm{Zn} & 78 & 86 \\ \mathrm{Ga} & 19 & 18 \\ \mathrm{Rb} & 5 & 8 \\ \mathrm{Sr} & 131 & 36 \\ \mathrm{Y} & 25 & 6 \\ \mathrm{Zr} & 65 & \\ \mathrm{Nb} & <1 & 2 \\ \mathrm{Ba} & 23 & 1 \\ \mathrm{La} & 4 & \\ \mathrm{Ce} & 9 & \\ \mathrm{Nd} & 7 & \\ \mathrm{~Pb} & 1 & \\ \mathrm{Th} & 1 & \end{array}$

$\begin{array}{rr}167 & 267 \\ 129 & 113 \\ 86 & 89 \\ 18 & 19 \\ 6 & 7 \\ 86 & 74 \\ 36 & 29 \\ 69 & 53 \\ 1 & <1 \\ 21 & 24 \\ 4 & 4 \\ 10 & 7 \\ 9 & 6 \\ 4 & 3 \\ 1 & 1\end{array}$

$\begin{array}{rr}278 & 382 \\ 163 & 142 \\ 74 & 81 \\ 14 & 17 \\ 6 & 5 \\ 111 & 88 \\ 22 & 24 \\ 57 & 46 \\ <1 & <1 \\ 16 & 19 \\ 3 & 4 \\ 5 & 6 \\ 5 & 6 \\ 2 & 3 \\ 1 & 1\end{array}$

Selected Element Ratios

$\begin{array}{lc}\mathrm{F} /(\mathrm{F}+\mathrm{M})^{\mathrm{c}} & 0.55 \\ \mathrm{Ca} / \mathrm{Al} & 0.74 \\ \mathrm{Zr} / \mathrm{Nb} & 65 \\ \mathrm{P} / \mathrm{Zr} & 4 \\ \mathrm{Ba} / \mathrm{Zr} & 0.35 \\ \mathrm{Ti} / \mathrm{Zr} & 96 \\ \mathrm{Y} / \mathrm{Zr} & 0.39 \\ \mathrm{Cr} / \mathrm{Ni} & 2.46\end{array}$

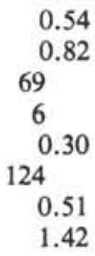

0.58
0.81
$>53$
8
0.45
128
0.55
2.42

$\begin{aligned} & 0.50 \\ & 0.72 \\ &>57 \\ & 4 \\ & 0.28 \\ & 92 \\ & 0.38 \\ & 1.75\end{aligned}$

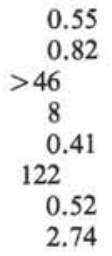

\footnotetext{
$\mathrm{a}_{\mathrm{wr}}=$ whole-rock average compositions.

$\mathrm{b}_{\mathrm{gl}}=$ glass average compositions.

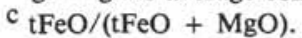

ated with clinopyroxene) are usually less calcic than isolated phenocrysts (Table 7, Analyses 7 and 8).

The range of plagioclase compositions in Holes 447A and 449 basalts are broadly similar: from $\mathrm{An}_{90}$ to $\mathrm{An}_{78}$ in Hole 447A (Table 7, Analyses 1, 2, 4, and 5) and from $\mathrm{An}_{87}$ to $\mathrm{An}_{78}$ in Hole 449 (Table 7, Analysis 7). Phenocrysts from Hole 450 are significantly more calcic, and compositions ranging from $\mathrm{An}_{94}$ to $\mathrm{An}_{84}$ are common (Table 7, Analysis 9).

Within Hole 447A, there is a general relationship between the compositions of the plagioclase phenocrysts and the host glasses. The two magma types found in Hole 447A are characterized by, among other things, different $\mathrm{Ca} / \mathrm{Al}$ ratios $(\sim 0.72$ in Units $\mathrm{C} 1$ and $\mathrm{C} 4$, $\sim 0.82$ in Units $\mathrm{C} 2, \mathrm{C} 3$, and $\mathrm{C} 5$ ). Although the data are limited, plagioclase phenocrysts from the former are less calcic $\left(\sim \mathrm{An}_{80}\right)$ than the average composition of phenocrysts from the latter $\left(\sim \mathrm{An}_{85}\right)$. Representative analyses of plagioclases from the two magma types are given in Table 7 (Analyses 1 and 2). In the magma type represented by the three Chemical Units C5, C3, and C2 (each progressively more evolved in terms of falling
$\mathrm{MgO}$ and $\mathrm{Ni}$ and rising $\mathrm{TiO}_{2}, \mathrm{Zr}$, etc.), the plagioclase phenocrysts also tend to become less calcic, falling from $A n_{91}$ to $A n_{80}$ in Unit C5, to $A n_{89}$ to $A n_{78}$ in Unit C3, and to $\mathrm{An}_{88}$ to $\mathrm{An}_{77}$ in Unit C2. It is emphasized that these correlations are only crude and could reflect equally well the greater influence of factors such as fluctuating $p_{\mathrm{H}_{2} \mathrm{O}}$ and degree of undercooling in the melt on the plagioclase-melt equilibria (Lofgroen et al., 1974; Drake, 1976).

Plagioclase crystals, interpreted as xenocrysts, are found at several horizons in Hole 447A basalts. These crystals differ from the equilibrium phenocrysts in that they are much larger, up to $2 \mathrm{~cm}$ in diameter, and have a smooth or corroded anhedral outline. Two types are recognized, based on differences in composition, style of zoning, and morphology. Representative analyses of both types of plagioclase xenocrysts are compared with associated phenocrysts in Table 7, Analyses 3, 4, 5, and 6.

Type 1. "More refractory" xenocrysts. These are considerably more calcic than associated equilibrium phenocrysts and are only found in Unit $\mathrm{C} 2$ basalts 

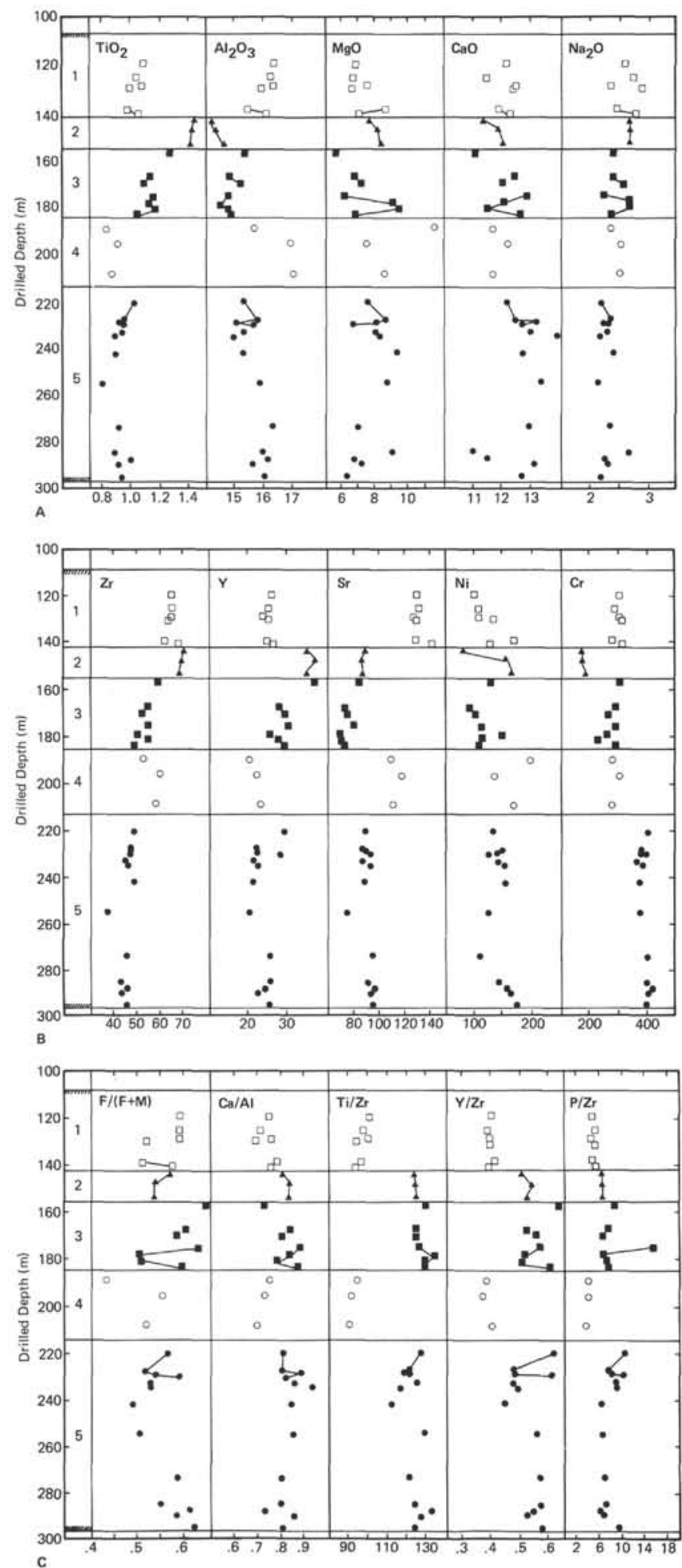

Figure 4. Down-hole geochemical variations (whole-rock XRF data) at Hole 447A, West Philippine Basin. (Selected major elements are shown in A, selected trace elements in B, and selected element ratios in C. Chemical Units C1-C5 are distinguished by a set of symbols consistent with the variation diagram in Fig. 3. F/(F + M) means $\mathrm{tFeO} /(\mathrm{FeO}+\mathrm{MgO})$.)

(Lithologic Unit L3a). Crystals range in size from 2 to 5 $\mathrm{mm}$ and are characterized by smoothly rounded or embayed outlines. They vary little in composition, from

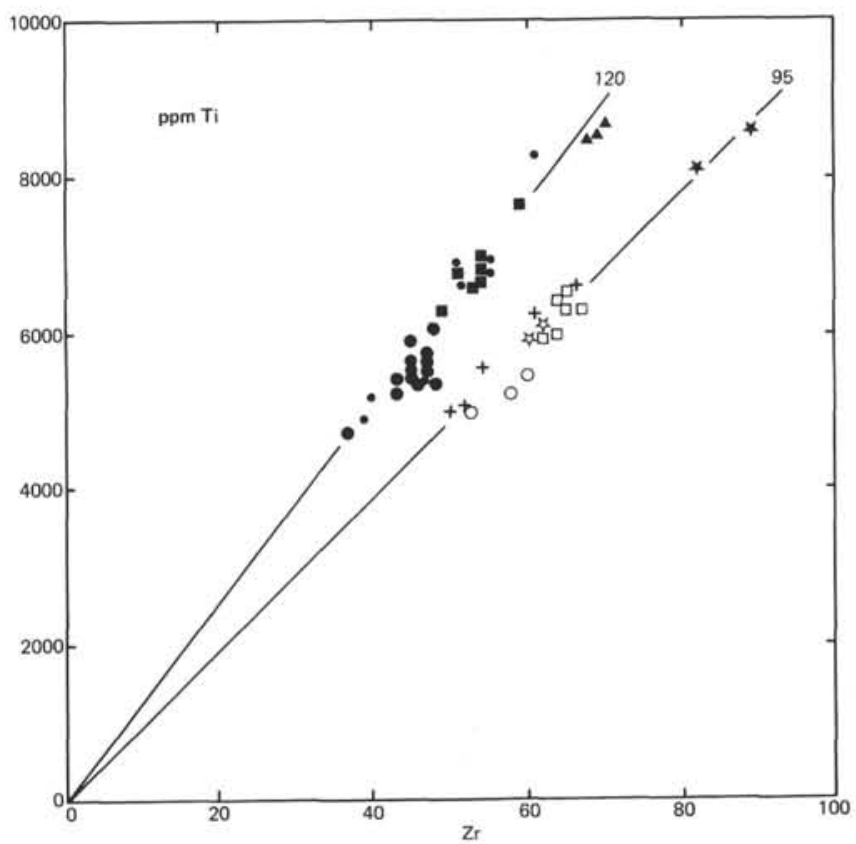

Figure 5. Titanium versus zirconium plot for basalts from Holes 449 (open stars), 450 (closed stars), and 447A (individual Chemical Units $\mathrm{C} 1-\mathrm{C} 5$ at Hole $447 \mathrm{~A}$ are distinguished as follows: open squares and circles $=$ Units $\mathrm{C} 1$ and $\mathrm{C} 4$, respectively [forming Magma Type 1]; closed triangles, squares, and large circles = Units $\mathrm{C} 2, \mathrm{C} 3$, and $\mathrm{C} 5$, respectively [forming Magma Type 2]. Crosses and small closed circles are unlabeled samples belonging to Magma Types 1 and 2 , respectively [see the preceding text on sampling techniques].)

$\mathrm{An}_{96}$ to $\mathrm{An}_{95}$ and are unzoned. Euhedral phenocrysts vary from $\mathrm{An}_{86}$ to $\mathrm{An}_{80}$ in the host basalts.

Type 2. "Less refractory" xenocrysts. These are typically similar to, or less calcic than, associated equilibrium phenocrysts and are found in two horizons in Hole 447A. The lower Unit C3 basalts (from Lithologic Unit L3d) contain relatively small $(1-3 \mathrm{~mm})$ xenocrysts ranging in composition from $\mathrm{An}_{83}$ to $\mathrm{An}_{74}$ and are partly mantled by a thin rim of plagioclase of similar composition to the euhedral phenocrysts $\left(A n_{89-81}\right)$. The lower basalts from Unit C5 (Lithologic Units L6e, f) contain more abundant and significantly larger (up to $2 \mathrm{~cm}$ ) crystals, which have a more ragged, abraded anhedral form. These xenocrysts are zoned by up to $5 \mathrm{~mol} \% \mathrm{An}$, with core compositions varying in the range $\mathrm{An}_{88}$ to $\mathrm{An}_{79}$; associated plagioclase phenocrysts are slightly more calcic $\left(\mathrm{An}_{90-80}\right)$. These xenocrysts are also associated with large (up to $5 \mathrm{~mm}$ ) aluminous chrome-spinels, and glomerophyric groups of both phases are sometimes found. Xenoliths of cumulate textured anorthosite, up to $5 \mathrm{~cm}$ in size, were recovered from the deepest basalts penetrated in Hole 447A. Individual crystals from the xenoliths are similar in appearance and composition to the isolated xenocrysts, hence the two may have been derived from the same source.

\section{Olivine}

Olivine is present as phenocrysts in the majority of glasses studied, except those from Hole 450. Composi- 


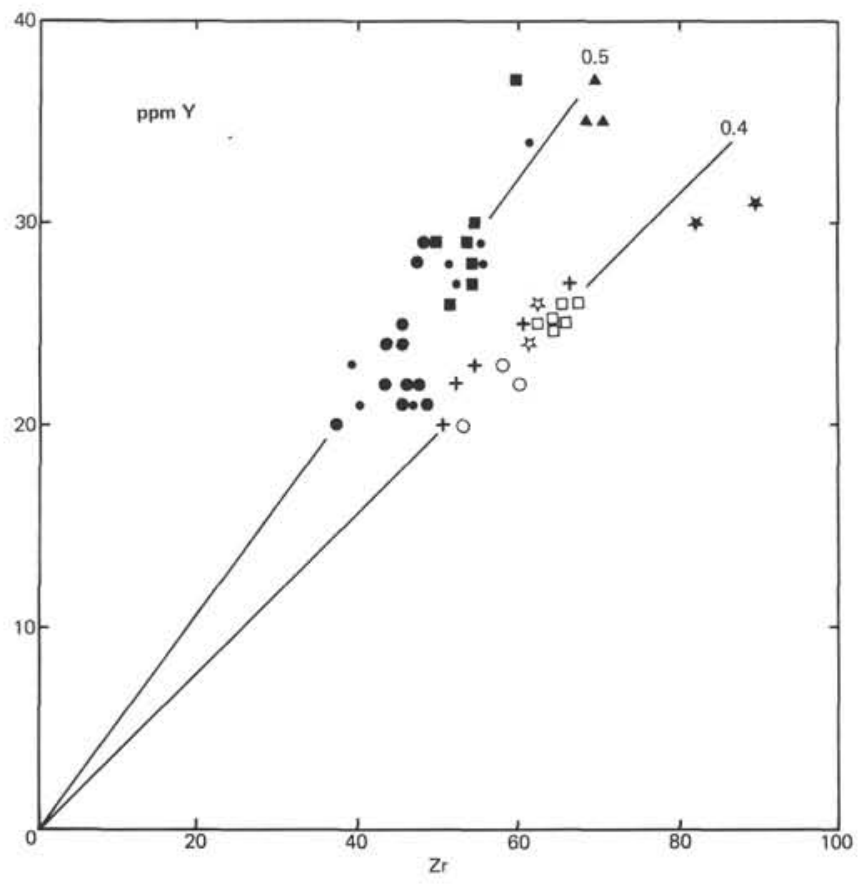

Figure 6. Yttrium versus zirconium plot for basalts from Holes 447A, 449 , and 450 (same symbols as in Fig. 5).

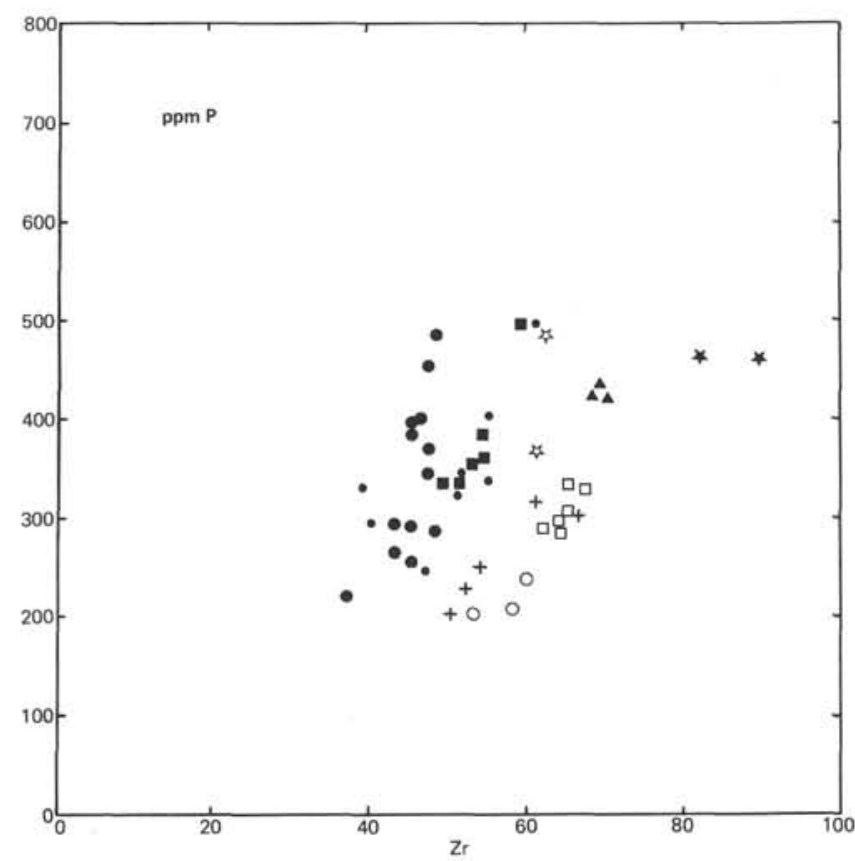

Figure 7. Phosphorus versus zirconium plot for basalts from Holes 447A, 449, and 450 (same symbols as in Fig. 5).

tional ranges are summarized in Figure 14. The overall variation extends from $\mathrm{Fo}_{88}$ to $\mathrm{Fo}_{81}$.

Compared to plagioclase, olivine phenocrysts portray a much more restricted range of core compositions (rarely exceeding $2 \mathrm{~mol} \mathrm{\%}$ of forsterite) and less extensive zoning (less than 1\% Fo). Unlike plagioclase, the olivine composition is closely related to the composition of the host glass, and each chemical unit is characterized

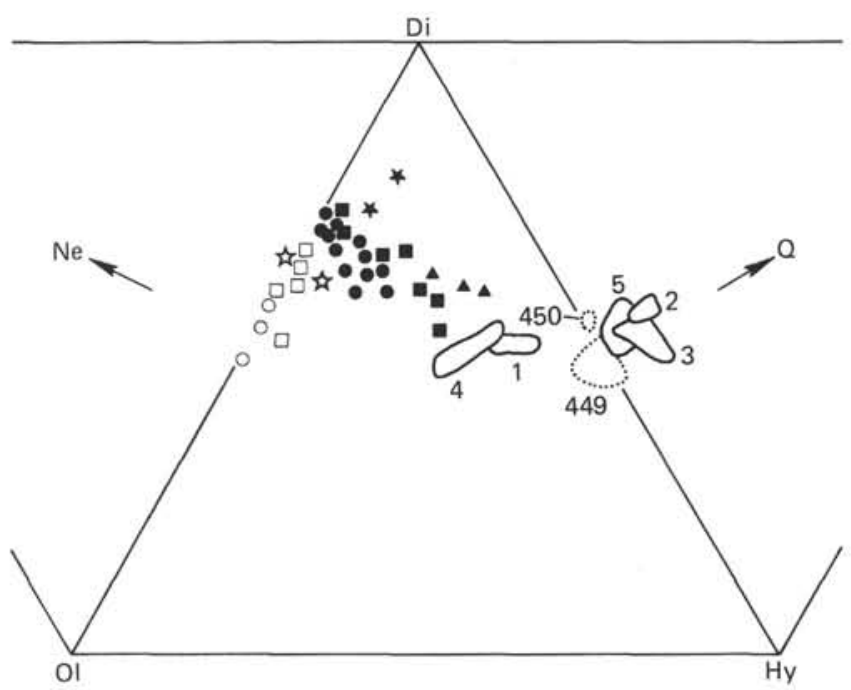

Figure 8. Basalt whole-rock analyses from Holes $447 \mathrm{~A}, 449$, and 450 plotted in the diopsite-olivine-hypersthene face of the basalt tetrahedron. (The symbols are the same as in Fig. 5. The fields of basalt glass compositions from the five chemical units from Hole 447A [labelled 1-5] and from Holes 449 and 450 are also plotted for comparison.)

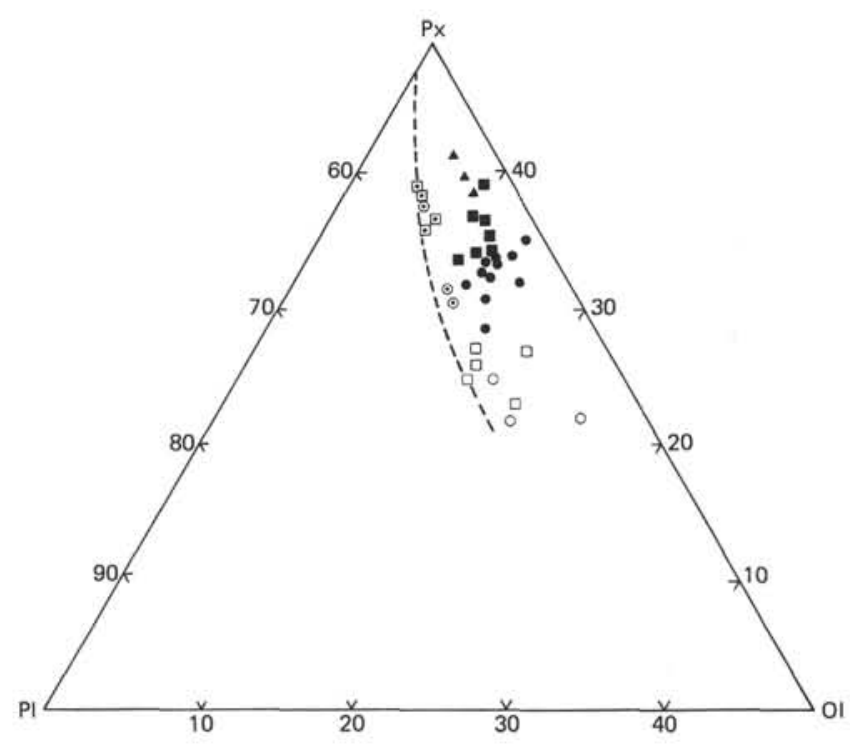

Figure 9. Basalt glasses and whole-rock samples from Hole 447A plotted in part of the pyroxene-plagioclase-olivine ternary diagram. (The symbols are the same as in Fig. 5. Glass analyses from Units C4 [partly filled circles] and C1 [partly filled squares] plot along the 1 bar cotectic curve of Miyashiro [1970].)

by a narrow range of olivine compositions. Table 8 compares the most magnesian olivine analysis from each unit in Hole 447A and in Hole 449. NiO varies from approximately $0.3 \%(\sim 2300 \mathrm{ppm})$ to below the detection limit of the electron-microprobe system $(0.15 \%, \sim 1000 \mathrm{ppm})$. $\mathrm{CoO}$ and $\mathrm{MnO}$ are also both close to the detection limit, and results are unreliable. $\mathrm{CaO}$ remains fairly constant at about $0.3 \%$, indicating that these olivines have equilibrated at low pressures (Simkin and Smith, 1970). 


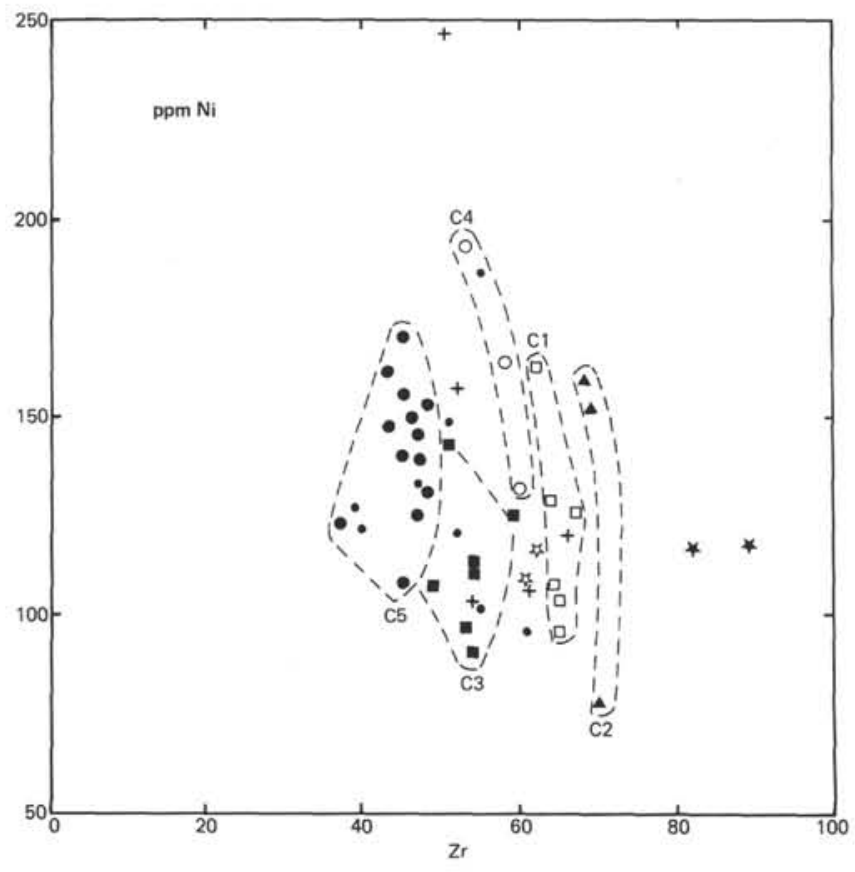

Figure 10. Nickel versus zirconium plot for basalts from Holes 447A, 449 , and 450 (same symbols as in Fig. 5).

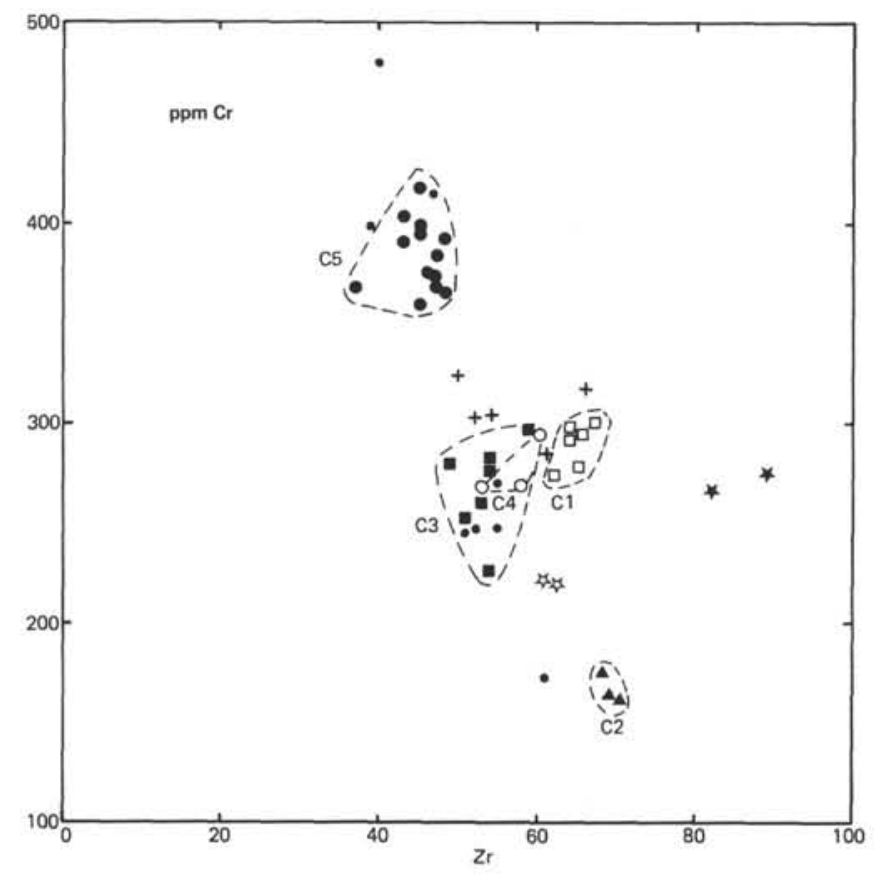

Figure 11. Chromium versus zirconium plot for basalt from Holes 447 A, 449, and 450 (same symbols as in Fig. 5).

The Fe-Mg distribution coefficient $K_{D}$ between olivine and liquid

$$
K_{D}=X_{\mathrm{FeO}}^{\mathrm{ol}} \cdot X_{\mathrm{MgO}}^{\mathrm{liq}} / X_{\mathrm{FeO}}^{\mathrm{liq}} \cdot X_{\mathrm{MgO}}^{\mathrm{ol}}
$$

(where $X_{\mathrm{FeO}}^{\mathrm{ol}}=$ the mole fraction of $\mathrm{FeO}$ in olivine, etc.) has been determined both experimentally and in natural

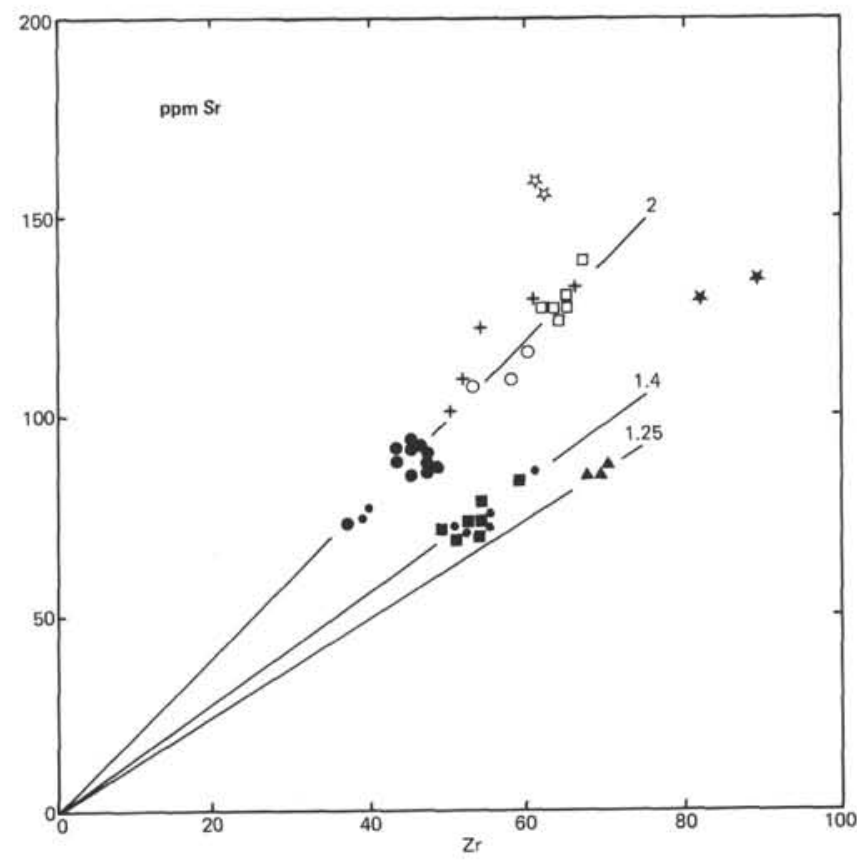

Figure 12. Strontium versus zirconium plot for basalts from Holes 447A, 449, and 450 (same symbols as in Fig. 5).

systems by a number of workers (Roeder and Emslie, 1970; Cawthorne et al., 1973; Thompson, 1975) and is found to remain approximately constant $(0.30-0.36)$ for a wide range of bulk compositions, pressures, and temperatures. The olivine data have been used to calculate apparent $K_{D}$ values for phenocryst-glass pairs to test whether all the phenocrysts are in equilibrium with the host glass. Larger anhedral crystals of olivine are also found in samples that contain uridoubted xenocrysts of plagioclase and pyroxene, and it is possible that these olivines may also be xenocrystic in origin.

The calculated $K_{D}$ values are plotted against the ironmagnesium ratio of the host glass in Figure 15. The glass analyses reflect the lower limit of $\mathrm{MgO}$ content of the primitive liquid, therefore the highest olivine-liquid $K_{D}$ values are the minimum true equilibrium $K_{D}$ value. Each chemical unit gives similar maximum $K_{D}$ values of 0.30 to 0.32 (Range A, Fig. 15). These are slightly lower than the value of 0.33 predicted by Cawthorne et al. (1973) and Thompson (1975), which probably suggests a higher $\mathrm{Fe}^{3+} / \mathrm{Fe}^{2+}$ ratio than the value of 0.15 used in the calculations. An assumed oxidation ratio of 0.20 in the glasses elevates the calculated $K_{D}$ values closer to the accepted value of 0.33 (e.g., Field B, Fig. 15).

The glasses from each chemical unit display a range of $K_{D}$ values extending as low as 0.25 . This array of values, all calculated from euhedral or skeletal olivine phenocryst compositions, is probably a result of earlyformed (magnesian) phenocrysts coming in contact with residual glass (i.e., more fractionated because of incipient groundmass crystallization). The larger anhedral olivines found in Units $\mathrm{C} 2$ and $\mathrm{C} 3$, however, give significantly lower $K_{D}$ values, ranging from 0.25 to 0.22 . In both of these units, considering all the $K_{D}$ values, the 
Table 6. Representative analyses of basalts and glasses from Holes 449 and 450 .

\begin{tabular}{|c|c|c|c|c|c|c|}
\hline \multirow{2}{*}{$\begin{array}{l}\text { Hole } \\
\text { Samplea }\end{array}$} & \multicolumn{3}{|c|}{449} & \multicolumn{3}{|c|}{450} \\
\hline & 1 & 2 & $\mathrm{gl}^{\mathrm{C}}$ & 3 & 4 & $\mathrm{gl}^{\mathrm{C}}$ \\
\hline $\mathrm{SiO}_{2}$ & 49.4 & 49.0 & 49.9 & 50.0 & 49.6 & 50.1 \\
\hline $\mathrm{TiO}_{2}$ & 0.99 & 1.02 & 0.91 & 1.43 & 1.35 & 1.43 \\
\hline $\mathrm{Al}_{2} \mathrm{O}_{3}$ & 14.3 & 14.9 & 16.5 & 15.2 & 15.4 & 14.9 \\
\hline $\mathrm{tFeO}^{\circ}$ & 9.36 & 9.84 & 9.30 & 8.20 & 8.38 & 9.43 \\
\hline $\mathrm{MnO}$ & 0.14 & 0.15 & 0.12 & 0.17 & 0.16 & 0.12 \\
\hline $\mathrm{MgO}$ & 9.14 & 7.74 & 7.59 & 7.58 & 7.40 & 7.47 \\
\hline $\mathrm{CaO}$ & 12.25 & 11.43 & 11.60 & 13.08 & 12.99 & 11.56 \\
\hline $\mathrm{Na}_{2} \mathrm{O}$ & 2.76 & 2.95 & 2.25 & 2.87 & 2.71 & 2.52 \\
\hline $\mathrm{K}_{2} \mathrm{O}$ & 0.46 & 0.39 & 0.15 & 0.23 & 0.37 & 0.08 \\
\hline $\mathrm{P}_{2} \mathrm{O}_{5}$ & 0.08 & 0.11 & & 0.11 & 0.11 & \\
\hline Total & 99.03 & 97.66 & - & 99.05 & 98.54 & - \\
\hline
\end{tabular}

Trace Elements (ppm)

$\begin{array}{lrrrr}\mathrm{Ni} & 108 & 116 & 118 & 117 \\ \mathrm{Cr} & 221 & 220 & 274 & 266 \\ \mathrm{Zn} & 63 & 92 & 71 & 69 \\ \mathrm{Ga} & 16 & 18 & 18 & 18 \\ \mathrm{Rb} & 5 & 4 & 2 & 4 \\ \mathrm{Sr} & 158 & 155 & 134 & 129 \\ \mathrm{Y} & 24 & 26 & 31 & 30 \\ \mathrm{Zr} & 61 & 62 & 89 & 82 \\ \mathrm{Nb} & 2 & 3 & 2 & 2 \\ \mathrm{Ba} & 32 & 29 & 23 & 23 \\ \mathrm{La} & 5 & 5 & 5 & 5 \\ \mathrm{Ce} & 9 & 7 & 10 & 13 \\ \mathrm{Nd} & 8 & 7 & 9 & 10 \\ \mathrm{~Pb} & <1 & 4 & 3 & 3 \\ \mathrm{Th} & <1 & 1 & <1 & 2\end{array}$

Selected Element Ratios

\begin{tabular}{lcccc}
$\mathrm{F} /(\mathrm{F}+\mathrm{M})^{\mathrm{b}}$ & 0.51 & 0.56 & 0.52 & 0.53 \\
$\mathrm{Ca} / \mathrm{Al}$ & 0.82 & 0.77 & 0.86 & 0.84 \\
$\mathrm{Zr} / \mathrm{Nb}$ & 30 & 21 & 45 & 41 \\
$\mathrm{Ba} / \mathrm{Zr}$ & 0.52 & 0.47 & 0.26 & 0.28 \\
$\mathrm{Ti} / \mathrm{Zr}$ & 97 & 99 & 96 & 99 \\
$\mathrm{Y} / \mathrm{Zr}$ & 0.39 & 0.42 & 0.35 & 0.37 \\
$\mathrm{Cr} / \mathrm{Ni}$ & 2.05 & 1.90 & 2.32 & 2.27 \\
\hline
\end{tabular}

a Samples: (1) $449-15-2,11 \mathrm{~cm}$, (2) $449-17-2,109 \mathrm{~cm}$, (3) $450-36-3,7 \mathrm{~cm}$, (4) $450-36-3,86 \mathrm{~cm}$.

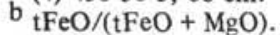

$\mathrm{c} \mathrm{gl}=$ average of glass analyses.

distribution is crudely bimodal. This evidence supports the postulate that these larger, anhedral olivines, which are clearly too magnesian to have crystallized from their host glasses, are xenocrysts.

\section{Pyroxene}

Clinopyroxene is found as glomerophyric intergrowths with plagioclase and as spectacularly resorbed xenocrysts in a few basalt samples from Hole 447A and as rare phenocrysts and glomerocrysts in the upper basalts from Hole 449. In Hole 447A, pyroxene-bearing basalts are limited to Lithologic Unit 3 and are most abundant (although subordinate to olivine and plagioclase) in Unit L3a (Chemical Unit C2). The resorbed grains of pyroxene are very small and rarely exceed 0.5 $\mathrm{mm}$ in size. Their morphology varies from examples that have irregular outlines with embayments to almost completely digested round grains less than $0.05 \mathrm{~mm}$ in diameter. In thin section, these pyroxenes are pale yellowish green in color, with frequent multiple twinning. No exsolution features are observed.

Glomerophyric clinopyroxenes are often found in the same samples as the resorbed crystals. These form intergranular or subophitic intergrowths with plagioclase (up to $2 \mathrm{~mm}$ in diameter), the latter usually being less calcic than the associated plagioclase phenocrysts. These clinopyroxenes are pale green in color, have a characteristic patchy extinction, and twinning is rare.

In Hole 449, both euhedral phenocrysts and glomerophyric clinopyroxenes are found in the upper basalts, associated with spinel-bearing plagioclase phenocrysts and rare olivine phenocrysts. These clinopyroxenes tend to be larger and more euhedral than their Hole 447A counterparts.

Four pyroxene-bearing glass margins from Hole $447 \mathrm{~A}$ and one from Hole 449 were studied by microprobe to elucidate the variation in pyroxene compositions. One sample, containing five resorbed crystals and three glomerophyric groups, was studied in detail (447A-18-1, $40 \mathrm{~cm}, 65$ analyses). The results are plotted in the pyroxene quadrilateral in Figure 16 (Hole 447A) and Figure 17 (Hole 449). Representative analyses are presented in Table 9. The glomerophyric pyroxenes and the resorbed pyroxenes from Hole 447A are compositionally different. Resorbed crystals are typically endiopsides and diopsidic augite ranging in composition from $\mathrm{Wo}_{43} \mathrm{En}_{50} \mathrm{Fs}_{7}$ to $\mathrm{Wo}_{36} \mathrm{En}_{55} \mathrm{Fs}_{9}$, with most variation in the Wo molecule at a constant $\mathrm{Mg} /(\mathrm{Mg}+\mathrm{Fe})(0.85)$. Although some crystals are slightly zoned (by a few mol $\%$ Wo), there is, in fact, a greater range in core compositions between crystals in the same sample. Glomerophyric crystals are slightly more iron-rich $[\mathrm{Mg} /(\mathrm{Mg}+$ $\mathrm{Fe})=0.82]$ and less calcic than the resorbed crystals and range in composition from $\mathrm{Wo}_{40} \mathrm{En}_{49} \mathrm{Fs}_{11}$ to $\mathrm{Wo}_{30} \mathrm{En}_{56}$ $\mathrm{Fs}_{14}$. Although there is variation in the Fs molecule, the dominant variation is again in Wo, but this time as zoning within single crystals.

The most important minor elements in these pyroxenes are $\mathrm{Cr}_{2} \mathrm{O}_{3}$ and $\mathrm{Al}_{2} \mathrm{O}_{3}$, followed by $\mathrm{TiO}_{2}$. The resorbed crystals are notably rich in $\mathrm{Cr}_{2} \mathrm{O}_{3}$, averaging $0.8 \%$ but sometimes reaching as high as $1.5 \%$; the glomerophyric pyroxenes are lower in $\mathrm{Cr}_{2} \mathrm{O}_{3}$, typically $0.15 \%$ to $0.4 \%$. No differences in $\mathrm{Al}_{2} \mathrm{O}_{3}$ contents are observed, and both equilibrium and nonequilibrium crystals average $2.5 \% \mathrm{Al}_{2} \mathrm{O}_{3}$ and range from $1 \%$ to $4 \%$. $\mathrm{TiO}_{2}$, however, is generally lower in the resorbed crystals (less than $0.5 \%$, average $0.2 \%$ ) than in the glomerocrysts (range $0.5-0.8 \%$ ).

Figures 18 and 19 show the results of a more detailed study of the differences and behavior of minor elements in resorbed and glomerophyric pyroxene crystals from one sample. The $\mathrm{Al}: \mathrm{Ti}$ relationships are illustrated in Figure 18, and it can be seen that the resorbed crystals are relatively more aluminous $(\mathrm{Al}: \mathrm{Ti}=15)$ compared with the glomerocrysts $(\mathrm{Al}: \mathrm{Ti}=10)$. The variation of $\mathrm{Al}, \mathrm{Ti}, \mathrm{Cr}$, and $\mathrm{Mg} /(\mathrm{Mg}+\mathrm{Fe})$ with $\mathrm{mol} \%$ Wo content suggests more of a continuous compositional trend linking resorbed and unresorbed crystals.

In general, the compositional difference between the resorbed grains and glomerophyric pyroxenes is small 

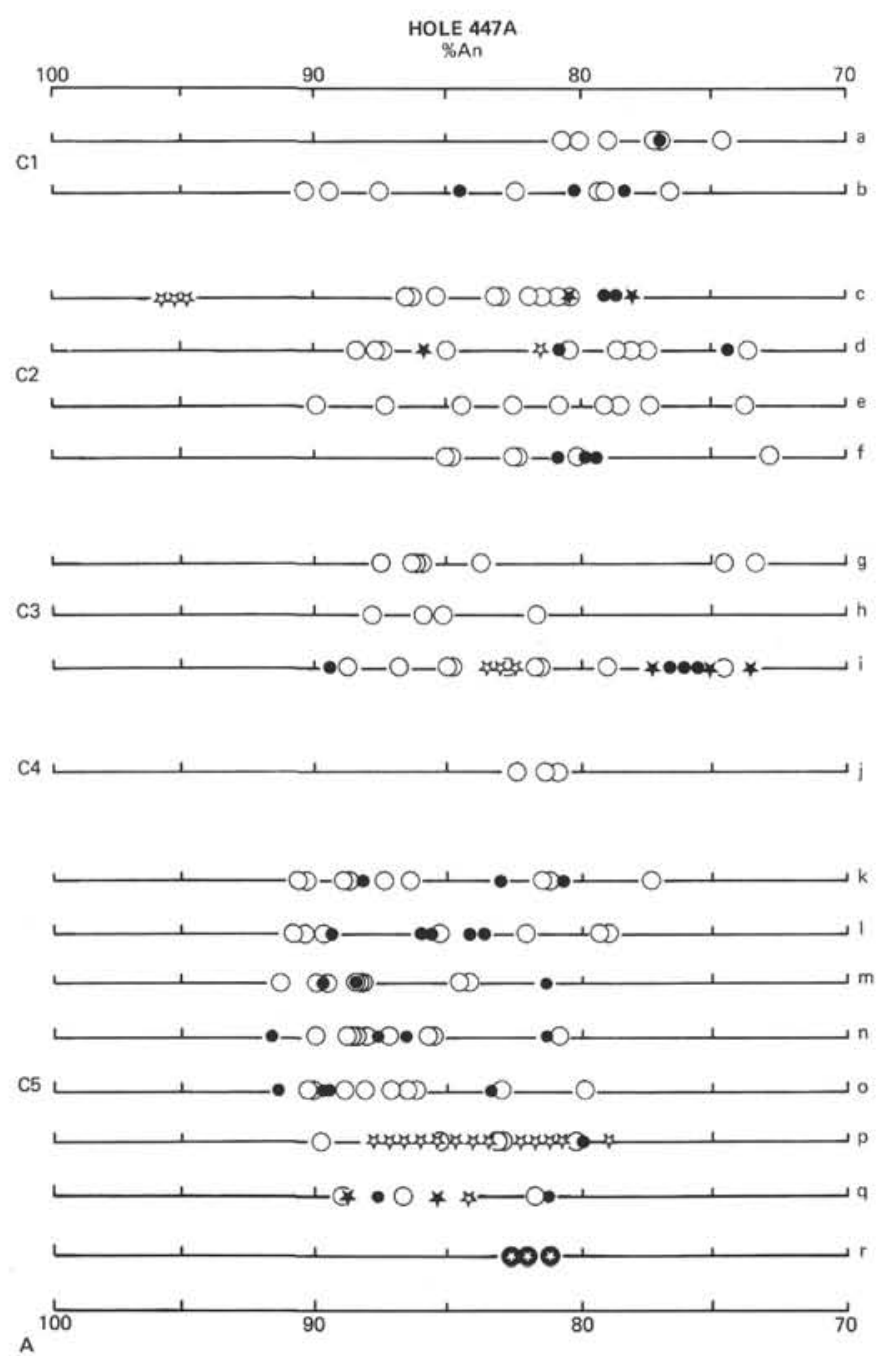

Figure 13. Summary of variation in composition of plagioclase phenocrysts (open circles = core analyses, closed circles $=$ rim analyses) and xenocrysts (open stars = core analyses, closed stars = rim analyses) from Holes 447A (A) and 449 and 450 (B). In A, samples [core-section, interval in $\mathrm{cm}$ ] from Hole 447A are designated by: $\mathrm{a}=14-3,60 \mathrm{~cm} ; \mathrm{b}=15-2,5 \mathrm{~cm} ; \mathrm{c}=16-2,45 \mathrm{~cm} ; \mathrm{d}=17-1,148 \mathrm{~cm} ; \mathrm{e}=18-1,40 \mathrm{~cm} ;(\mathrm{f}=\mathrm{GL}-31) ; \mathrm{g}$ $=19-3,62 \mathrm{~cm} ; \mathrm{h}=21-5,2 \mathrm{~cm} ; \mathrm{i}=22-1,20 \mathrm{~cm} ; \mathrm{j}=25-2,125 \mathrm{~cm} ; \mathrm{k}=28-1,140 \mathrm{~cm} ; \mathrm{l}=30-3,45 \mathrm{~cm} ; \mathrm{m}=31-4,35 \mathrm{~cm} ; \mathrm{n}=35-2,145 \mathrm{~cm} ; \mathrm{o}=$ $36-3,40 \mathrm{~cm} ; \mathrm{p}=36-4,77 \mathrm{~cm} ; \mathrm{q}=37-1,110 \mathrm{~cm}$; and $\mathrm{r}=$ anorthosite zenolith, 36-3, [R. B. Scott, personal communication]. In B, samples [hole-core, interval in $\mathrm{cm}$ ] from Hole 449 are designated by $\mathrm{s}=14-1,1 \mathrm{~cm}$ and $\mathrm{t}=15-1,130 \mathrm{~cm}$ and from $\mathrm{Hole} 450$ by $\mathrm{u}=36-3,1 \mathrm{~cm}$ and $\mathrm{v}=$ $36-3,133 \mathrm{~cm}$.)

though significant. This is surprising in view of the contrasting crystal forms present in the same samples.

In Hole 449, rare euhedral phenocrysts of endiopsidic augite are found that are very similar in composition to the resorbed pyroxene crystals in Hole 447A (Table 9, Fig. 17). The phenocrysts are up to $2 \mathrm{~mm}$ in size and display no evidence of resorption. These are associated with glomerocrysts of a less calcic, chrome-poor augite, similar in composition to those from Hole 447A.

\section{Spinel}

Spinel (magnesiochromite) is present as rare inclusions, microphenocrysts, and resorbed grains in the more magnesian lavas from Holes $447 \mathrm{~A}$ and 449 . The compositional variation found in the 50 spinels analyzed is summarized in Figure 20, a projection onto the $[\mathrm{Cr} /(\mathrm{Cr}+\mathrm{Al})] /\left[\mathrm{Mg} /\left(\mathrm{Mg}+\mathrm{Fe}^{2+}\right)\right]$ face of the spinel prism. Representative analyses are presented in Table 10.

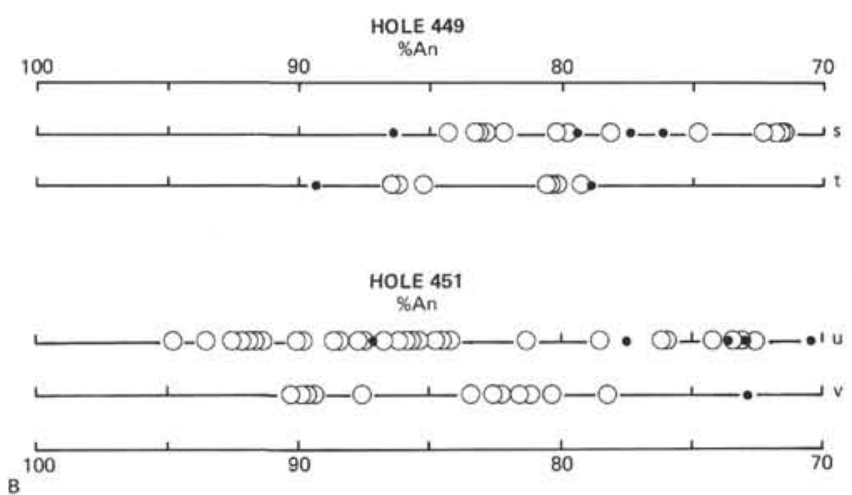

B (1) . 
Table 7. Representative analyses of plagioclase phenocrysts and xenocrysts.

\begin{tabular}{|c|c|c|c|c|c|c|c|c|c|}
\hline \multirow{2}{*}{$\begin{array}{l}\text { Hole } \\
\text { Anal.a }\end{array}$} & \multicolumn{6}{|c|}{$447 \mathrm{~A}$} & \multicolumn{2}{|c|}{449} & \multirow{2}{*}{$\frac{450}{9}$} \\
\hline & 1 & 2 & 3 & 4 & 5 & 6 & 7 & 8 & \\
\hline Typeb & p & p & $x$ & p & p & $x$ & D & $p$ & p \\
\hline $\mathrm{SiO}_{2}$ & 48.72 & 46.04 & 45.12 & 47.84 & 47.34 & 48.92 & 49.08 & 51.96 & 47.29 \\
\hline $\mathrm{Al}_{2} \mathrm{O}_{3}$ & 32.97 & 34.19 & 35.65 & 33.19 & 33.90 & 32.39 & 32.07 & 30.07 & 35.09 \\
\hline $\mathrm{FeO}$ & 0.41 & 0.37 & 0.26 & 0.29 & 0.35 & 0.46 & 0.49 & 0.65 & 0.29 \\
\hline $\mathrm{CaO}$ & 15.91 & 18.01 & 18.49 & 16.51 & 17.15 & 15.79 & 15.67 & 13.89 & 16.40 \\
\hline $\mathrm{Na}_{2} \mathrm{O}$ & 2.10 & 0.95 & 0.54 & 1.44 & 1.36 & 1.73 & 1.80 & 2.95 & 0.62 \\
\hline $\mathrm{K}_{2} \mathrm{O}$ & n.d. & n.d. & n.d. & n.d. & n.d. & n.d. & n.d. & 0.15 & n.d \\
\hline Total & 100.11 & 99.56 & 100.06 & 99.28 & 100.10 & 99.29 & 99.11 & 99.67 & 99.69 \\
\hline \multicolumn{10}{|c|}{ Cation Proportions on the Basis of 8 Oxygens } \\
\hline $\mathrm{Si}$ & 2.225 & 2.128 & 2.076 & 2.203 & 2.169 & 2.248 & 2.259 & 2.369 & 2.161 \\
\hline Al & 1.775 & 1.864 & 1.934 & 1.802 & 1.831 & 1.755 & 1.740 & 1.616 & 1.891 \\
\hline $\mathrm{Fe}^{2+}$ & 0.016 & 0.014 & 0.011 & 0.011 & 0.013 & 0.018 & 0.019 & 0.025 & 0.011 \\
\hline $\mathrm{Ca}$ & 0.779 & 0.892 & 0.912 & 0.815 & 0.842 & 0.778 & 0.773 & 0.679 & 0.803 \\
\hline $\mathrm{Na}$ & 0.186 & 0.085 & 0.048 & 0.129 & 0.121 & 0.154 & 0.161 & 0.260 & 0.055 \\
\hline K & - & - & - & - & - & - & - & 0.008 & - \\
\hline Sum & 4.981 & 4.983 & 4.981 & 4.960 & 4.976 & 4.953 & 4,952 & 4.957 & 4.921 \\
\hline An & 80.7 & 91.3 & 95.0 & 86.4 & 87.5 & 83.5 & 82.7 & 71.6 & 93.6 \\
\hline $\mathrm{Ab}$ & 19.3 & 8.7 & 5.0 & 13,6 & 12.5 & 16.5 & 17,3 & 27.5 & 6.4 \\
\hline Or & - & - & - & - & - & - & - & 0.9 & - \\
\hline $\mathrm{F} / \mathrm{F}+\mathrm{M})^{\mathrm{c}}$ & 0.48 & 0.50 & \multirow{2}{*}{\multicolumn{2}{|c|}{$\begin{array}{l}0.55 \\
0.82\end{array}$}} & \multicolumn{2}{|c|}{0.51} & \multicolumn{2}{|c|}{0.55} & 0.56 \\
\hline $\mathrm{Ca} / \mathrm{Al} \mathrm{C}$ & 0.71 & 0.85 & & & \multicolumn{2}{|c|}{0.82} & \multicolumn{2}{|c|}{0.70} & 0.77 \\
\hline
\end{tabular}

$a_{1}=$ Calcic phenocryst from LSa, (Chemical Unit C4), (Sample 447A-25-2, $125 \mathrm{~cm}$ );

$2=$ calcic phenocryst from L6e (CS), (Sample $447 \mathrm{~A} \cdot 31-4,35 \mathrm{~cm}$ );

$3=$ extremely calcic xenocryst from L3a (Sample 447A-16-2

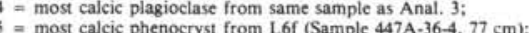

$6=$ core of less-caleic xenocryst from Lof (Sample $447 \mathrm{~A} \cdot 36-3,40 \mathrm{~cm})$

$7=$ most calcic phenocryst containing spinel inclusions (Sample 449-14-1, $1 \mathrm{~cm}$ );

= plagioclase glomerophyric with augite, from same sample as Anal, 7 ,

$9=$ most calcic phenocryst (Sample 450-36-3, $1 \mathrm{~cm}$ ).

$b p=$ phenocryst: $x=$ xenocryst (this notation will be used in the minetalogic tables that follow). Ratios in host glasses, $1 \mathrm{FeO} /(\mathrm{tFeO}+\mathrm{MgO})$

2) Significantly larger spinel crystals, characterized by an embayed or pitted appearance, are found in the lowest Unit C5 basalts (associated with plagioclase xenocrysts and xenoliths [anorthosite]), as inclusions within plagioclase phenocrysts in Unit $\mathrm{C} 2$ basalts, and in the upper basalts from Hole 449. These spinels are distinctly more aluminous $[\mathrm{Cr} /(\mathrm{Cr}+\mathrm{Al})=0.43-0.38]$ and are among the most magnesian $\left[\mathrm{Mg} /\left(\mathrm{Mg}+\mathrm{Fe}^{2+}\right)=\right.$ 0.74-0.66] spinels found in Leg 59 basalts (Fig. 20; Table 10, Analyses 6-9). Those found in Unit C5 basalts range from 200 to $1000 \mu \mathrm{m}$ in size, whereas those from Unit C2 and from Hole 449 basalts are somewhat smaller $(50-500 \mu \mathrm{m})$. In Unit C5 basalts, resorbed spinels are found as free-floating crystals or as inclusions in olivine phenocrysts, often side by side with equilibrium spinels. Noticeably light in color, these spinels are yellowish brown in comparison to the euhedral reddish brown microphenocrysts. The aluminous spinels from Unit C2 and from Hole 449 are less pitted and were probably protected from reaction by the plagioclase that now surrounds them. This armoring of the spinel by plagioclase would also account for the unusual coexistence of this phase with clinopyroxene phenocrysts in Hole 449. Spinel is generally absent from basalts bearing clinopyroxene phenocrysts; to explain this coexistence, a liquid-spinel-clinopyroxene reaction relation (at the expense of spinel) has been proposed by Irvine (1967) and by Hill and Roeder (1975).

Aluminous spinels with $\mathrm{Cr} /(\mathrm{Cr}+\mathrm{Al})$ as low as 0.20 have been reported from mid-ocean ridge basalts by Bryan (1972), Frey et al., (1974), Sigurdsson (1976), and Dick (1976). Most authors agree that aluminous spinels represent crystallization at elevated pressures, which probably commences at mantle pressures for the most

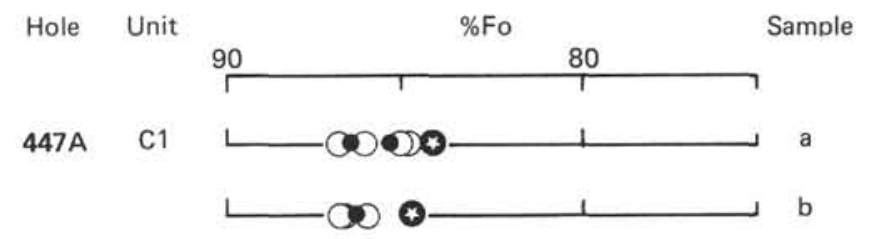

C2

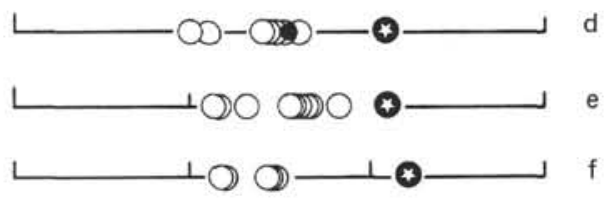

C3

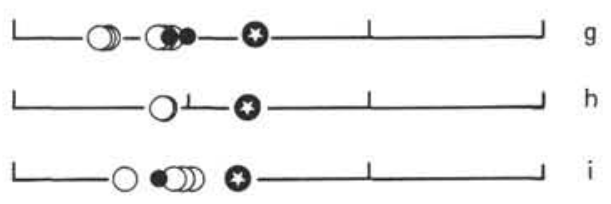

C4

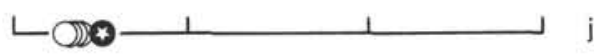

449
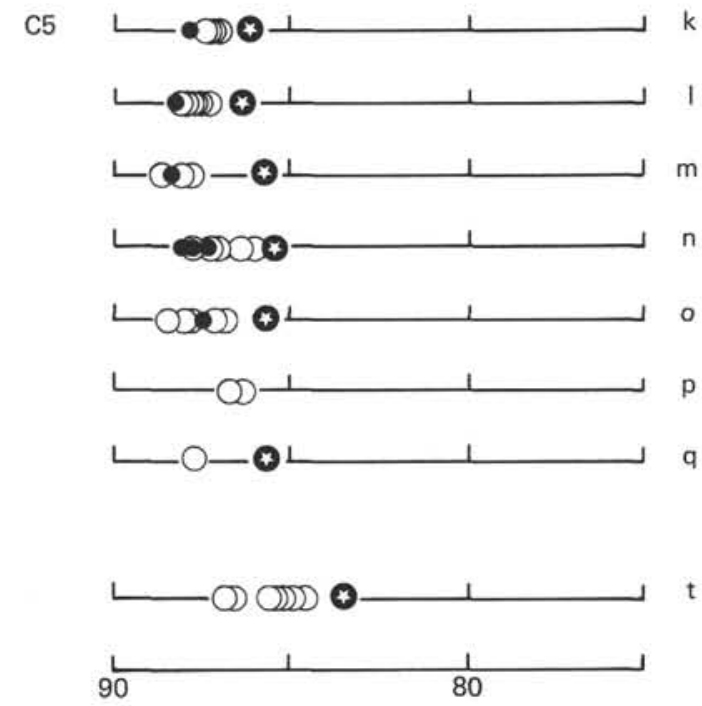

Figure 14. Summary of variation in composition of olivine phenocrysts in basalts from the different chemical units from Holes 447A and 449. (Samples are designated by the same letters as in Fig. 13. Open circles $=$ cores, closed circles $=$ rims, stars $=$ calculated olivine composition in equilibrium with host glass, using $K_{D}=0.33, \mathrm{Fe}^{3+} /\left(\mathrm{Fe}^{3+} \mathrm{Fe}^{2+}\right)=0.15$ [see text for details].)

aluminous compositions. The Leg 59 aluminous spinels plot toward the Cr-poor edge of the MORB magnesiochromite field and are not nearly as aluminous as the Atlantic chromian-spinels (Fig. 20). Nevertheless, they are significantly more aluminous than the equilibrium microphenocrysts in the same samples and probably crystallized in shallow-level reservoirs prior to eruption. 
Table 8. Representative analyses of olivine phenocrysts and a xenocryst.

\begin{tabular}{|c|c|c|c|c|c|c|c|}
\hline \multirow{3}{*}{$\begin{array}{l}\text { Hole } \\
\text { Anal.a } \\
\text { Type }\end{array}$} & \multicolumn{6}{|c|}{$447 \mathrm{~A}$} & \multirow{2}{*}{$\begin{array}{c}449 \\
7\end{array}$} \\
\hline & 1 & 2 & 3 & 4 & 5 & 6 & \\
\hline & $\mathrm{p}$ & p & $x$ & $\mathrm{p}$ & $\mathrm{p}$ & $\mathrm{p}$ & $\mathrm{p}$ \\
\hline $\mathrm{SiO}_{2}$ & 40.47 & 40.22 & 39.83 & 40.01 & 40.41 & 40.21 & 39.85 \\
\hline $\mathrm{FeO}$ & 12.53 & 16.46 & 14.07 & 13.95 & 10.80 & 11.85 & 14.31 \\
\hline $\mathrm{MnO}$ & n.d. & 0.16 & 0.25 & n.d. & 0.21 & 0.24 & 0.23 \\
\hline $\mathrm{MgO}$ & 45.82 & 42.89 & 44.48 & 44.40 & 46.88 & 46.92 & 44.70 \\
\hline $\mathrm{CaO}$ & 0.28 & 0.23 & 0.29 & 0.33 & 0.33 & 0.25 & 0.22 \\
\hline $\mathrm{NiO}$ & 0.33 & 0.23 & 0.21 & 0.30 & 0.28 & n.d. & 0.28 \\
\hline $\mathrm{CoO}$ & 0.19 & n.d. & n.d. & 0.25 & 0.30 & 0.23 & 0.32 \\
\hline Total & 99.61 & 100.22 & 99.11 & 99.24 & 99.21 & 99.70 & 99.91 \\
\hline \multicolumn{8}{|c|}{ Cation Proportions on the Basis of 4 Oxygens } \\
\hline $\mathrm{Si}$ & 1.011 & 1.014 & 1.006 & 1.009 & 1.006 & 1.000 & 1.001 \\
\hline $\mathrm{Fe}^{2+}$ & 0.262 & 0.347 & 0.297 & 0.294 & 0.225 & 0.246 & 0.301 \\
\hline Mn & - & 0.003 & 0.005 & - & 0.004 & 0.005 & 0.005 \\
\hline $\mathrm{Mg}$ & 1.706 & 1.611 & 1.674 & 1.668 & 1.739 & 1.738 & 1.674 \\
\hline $\mathrm{Ca}$ & 0.008 & 0.006 & 0.008 & 0.009 & 0.009 & 0.007 & 0.006 \\
\hline $\mathrm{Ni}$ & 0.007 & 0.005 & 0.004 & 0.006 & 0.006 & - & 0.006 \\
\hline Co & 0.004 & - & - & 0.005 & 0.006 & 0.005 & 0.006 \\
\hline Sum & 2.996 & 2.986 & 2.994 & 2.991 & 2.994 & 3.000 & 2.999 \\
\hline Fo & 86.7 & 82.3 & 84.9 & 85.0 & 88.6 & 87.6 & 84.8 \\
\hline$K_{D^{b}}^{\mathrm{b}}$ & 0.27 & 0.28 & 0.23 & 0.30 & 0.28 & 0.27 & 0.30 \\
\hline
\end{tabular}

$\mathrm{a}_{1}$ = Magnesian phenocryst from Cl (Sample 447A-14-3, $60 \mathrm{~cm}$ );

2 = magnesian phenocryst from C2 (Sample 447A-17-1, $148 \mathrm{~cm}$ )

3 = xenocryst(?) from same sample as Anal. 2;

4 = magnesian phenocryst from C3 (Sample 447A-22-1, $20 \mathrm{~cm}$ );

5 = magnesian phenocryst from C4 (Sample 447A-25-2, $125 \mathrm{~cm}$ );

6 = magnesian phenocryst from C5 (Sample 447A-36-3, $40 \mathrm{~cm}$ );

7 = magnesian phenocryst from Hole 449 (Sample 449-15-1, $130 \mathrm{~cm}$ )

$\mathrm{b}$ Olivine/glass iron-magnesium distribution coefficient (see text).

\section{Alteration Chemistry of Leg 59 Basalts}

All the basalts analyzed show slight to moderate lowtemperature seawater alteration. This type of alteration is generally characterized by hydration and an increase in the $\mathrm{Fe}^{3+} / \mathrm{Fe}^{2+}$ ratio. The behavior of major- and trace-elements during seawater alteration has been described by many authors (e.g., Hart, 1970; Nicholls and Islam, 1971; Hart et al., 1974; Pearce and Cann, 1973; Scott and Hajash, 1976; Thompson and Humphris, 1977; Floyd and Tarney, 1979). The resulting chemical changes generally involve increases in $\mathrm{H}_{2} \mathrm{O}$, $\mathrm{Fe}_{2} \mathrm{O}_{3}, \mathrm{~K}_{2} \mathrm{O}, \mathrm{Rb}, \mathrm{Ba}, \mathrm{Sr}, \mathrm{Th}, \mathrm{Pb}$, and $\mathrm{Ce}$, and decreases in $\mathrm{SiO}_{2}, \mathrm{Al}_{2} \mathrm{O}_{3}$, and $\mathrm{MgO}$. A few elements such as $\mathrm{Al}_{2} \mathrm{O}_{3}$ and $\mathrm{CaO}$ can increase or decrease. Although small increases in $\mathrm{TiO}_{2}, \mathrm{P}_{2} \mathrm{O}_{5}$, and $\mathrm{Zr}$ have been noted (Hart, 1970; Shido et al., 1974), these elements together with $\mathrm{Y}, \mathrm{Nb}, \mathrm{Cr}$, and $\mathrm{Ni}$ are generally considered to be stable (Pearce and Cann, 1973).

In this study, the chemical effects of alteration have been identified in two ways:

1) by comparing fresh glass and altered basalt from the same flow unit; and

2) by comparing the degree of scatter in binary plots of elements that would normally behave coherently in a comagmatic suite.

An altered pillow from Lithologic Unit L3d was studied in detail in order to estimate the relative mobility of the major elements. The pillow selvage is about $1.5 \mathrm{~cm}$ wide and grades into a brown oxidized variolytic zone $(\sim 1 \mathrm{~cm}$ wide). The interior of the pillow, $30 \mathrm{~cm}$ from the margin, is composed of pale brown sparsely phyric variolytic to intersertal basalt (approximately $60 \%$ crystalline). Olivine phenocrysts are replaced by brown smectites and amorphous oxides; plagioclase phenocrysts are partly replaced or veined with carbonates. Groundmass plagioclase and clinopyroxene are relatively fresh; the glassy mesostasis is replaced by clays, carbonates, and some zeolites. The outermost

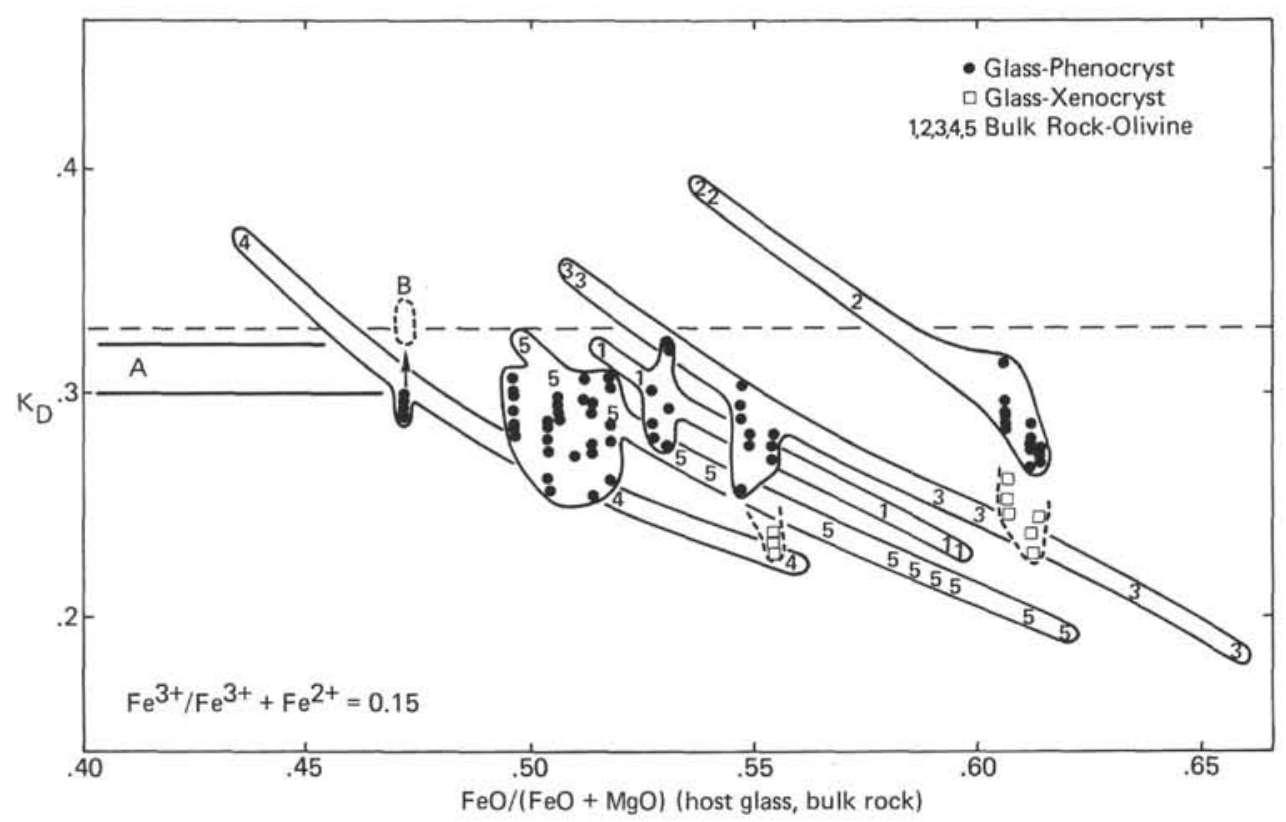

Figure 15. Plot of $K_{D}$ (Fe/Mg distribution coefficient between olivine and host glass or bulk rock versus the $\mathrm{FeO} /(\mathrm{FeO}+\mathrm{MgO})$ for host glass and bulk rock). Horizontal dotted line is accepted $K_{D}$ value of 0.33 [see text]. Range A is the range of maximum olivine-host glass calculated $K_{D}$ values for all sample pairs studied. Field B shows the effect of increasing the oxidation ratio of host glass from 0.15 to 0.20 .) 

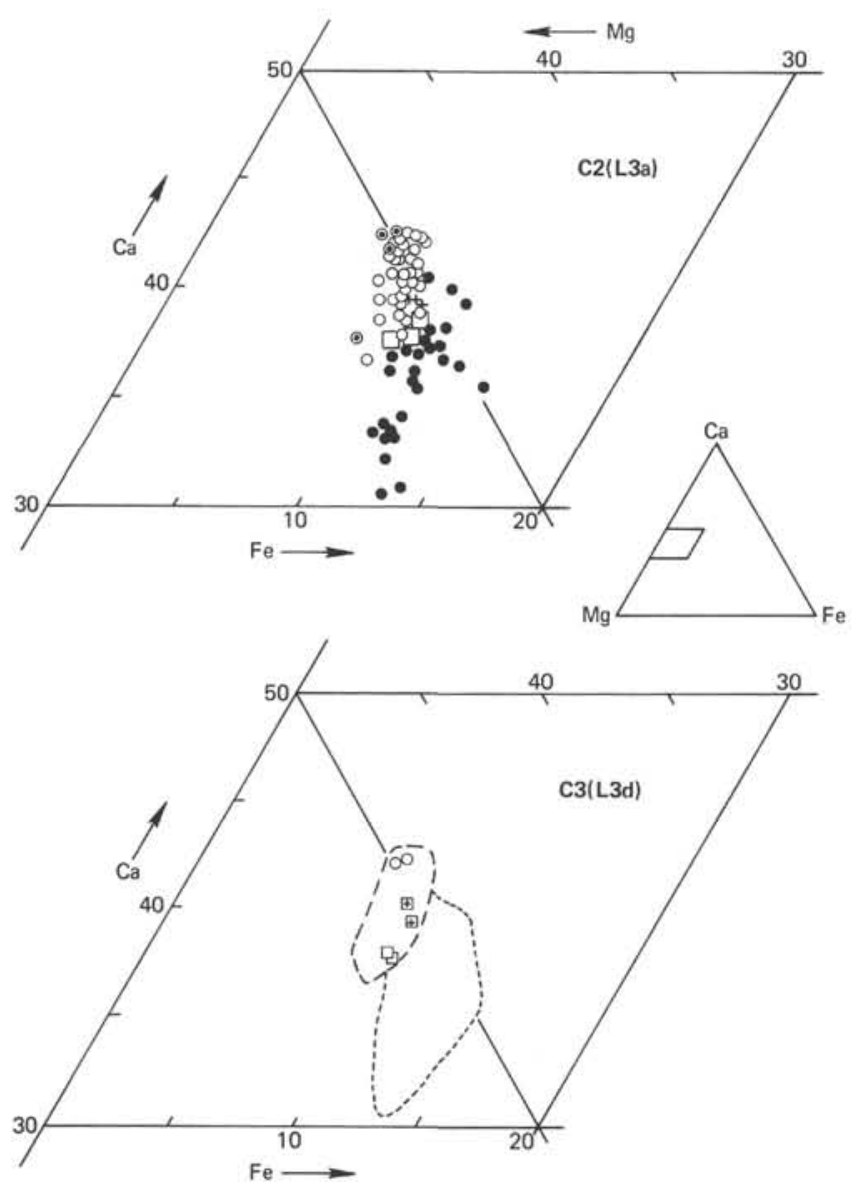

Figure 16. Pyroxene xenocrysts and glomerocryst compositions from Units C2 and C3, Hole 447A, plotted in pyroxene quadrilateral. (In the Unit $\mathrm{C} 2$ pyroxene quadrilateral, xenocrysts = open circles, squares $=$ crystals with glass inclusions, and closed circles $=$ glomerocrysts, of Sample 447A-18-1, $40 \mathrm{~cm}$ [Sample e, in Figs. 13 and 14); partly filled circles $=$ xenocrysts of Samples 447A-17-1, $148 \mathrm{~cm}$ [Sample d, Figs. 13 and 14]; crosses = xenocrysts of Sample 447A-96-3 [Sample f, Figs. 13 and 14]. In the Unit C3 pyroxene quadrilateral, circles and squares with crosses $=$ xenocryst cores, open squares $=$ xenocryst rim, Sample $447 \mathrm{~A}-22-1,20 \mathrm{~cm}$.)

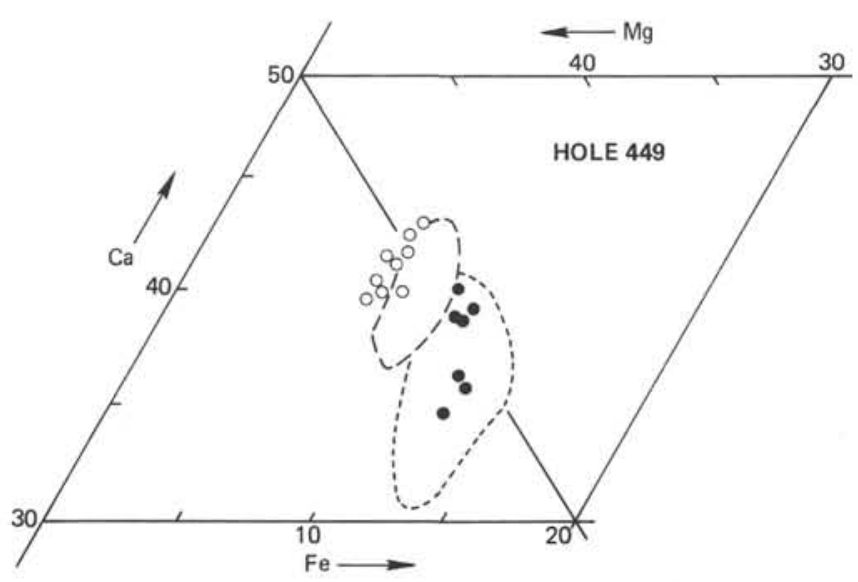

Figure 17. Pyroxene xenocryst and glomerocryst compositions from Hole 449 (Sample 449-15-1, $130 \mathrm{~cm}$, Sample t, Figs. 13, 14) plotted in a portion of the pyroxene quadrilateral (same as Fig. 16). (Open circles $=$ xenocrysts, closed circles $=$ glomerocrysts. $)$
Table 9. Representative analyses of resorbed and glomerophyric augites.

\begin{tabular}{lcccccccc}
\hline Hole & \multicolumn{9}{c}{$447 \mathrm{~A}$} \\
\hline Type & $\mathrm{x}$ & $\mathrm{x}$ & $\mathrm{x}(?)$ & $\mathrm{g}$ & $\mathrm{g}$ & $\mathrm{x}$ & $\mathrm{p}$ & $\mathrm{g}$ \\
\hline Anal. & 1 & 2 & 3 & 4 & 5 & 6 & 7 & 8 \\
\hline $\mathrm{SiO}_{2}$ & 52.78 & 52.94 & 54.76 & 53.45 & 54.49 & 52.22 & 53.67 & 52.20 \\
$\mathrm{TiO}_{2}$ & 0.31 & 0.28 & 0.30 & 0.50 & 0.67 & 0.23 & 0.17 & 0.52 \\
$\mathrm{Al}_{2} \mathrm{O}_{3}$ & 2.67 & 2.13 & 1.94 & 3.03 & 3.66 & 2.54 & 1.75 & 4.00 \\
$\mathrm{Cr}_{2} \mathrm{O}_{3}$ & 1.00 & 0.52 & 0.23 & 0.45 & 0.24 & 0.80 & 0.47 & 0.37 \\
$\mathrm{FeO}$ & 5.07 & 5.83 & 6.12 & 6.44 & 6.76 & 5.03 & 4.86 & 7.73 \\
$\mathrm{MnO}$ & - & - & 0.20 & - & - & - & - & - \\
$\mathrm{MgO}$ & 17.50 & 17.88 & 18.21 & 17.67 & 17.63 & 17.52 & 17.99 & 17.53 \\
$\mathrm{CaO}$ & 20.06 & 19.22 & 19.14 & 18.67 & 17.81 & 20.62 & 20.11 & 17.31 \\
$\mathrm{CoO}$ & - & 0.13 & - & - & - & - & 0.17 & - \\
$\mathrm{V}_{2} \mathrm{O}_{5}$ & - & - & - & - & 0.15 & 0.14 & - & 0.31 \\
$\mathrm{Total}$ & 99.39 & 99.93 & 100.90 & 100.21 & 100.41 & 99.10 & 99.19 & 100.07
\end{tabular}

Cation Proportions on the Basis of 6 Oxygens

\begin{tabular}{lclllllll}
$\mathrm{Si}$ & 1.934 & 1.950 & 1.971 & 1.941 & 1.911 & 1.924 & 1.966 & 1.906 \\
$\mathrm{Al} I V$ & 0.066 & 0.050 & 0.029 & 0.059 & 0.089 & 0.076 & 0.034 & 0.094 \\
$\mathrm{Al} V I$ & 0.049 & 0.043 & 0.054 & 0.071 & 0.068 & 0.034 & 0.041 & 0.082 \\
$\mathrm{Ti}$ & 0.009 & 0.008 & 0.008 & 0.014 & 0.018 & 0.006 & 0.005 & 0.014 \\
$\mathrm{Cr}$ & 0.029 & 0.015 & 0.006 & 0.013 & 0.007 & 0.023 & 0.014 & 0.011 \\
$\mathrm{Fe}^{2+}$ & 0.155 & 0.180 & 0.186 & 0.196 & 0.236 & 0.155 & 0.149 & 0.236 \\
$\mathrm{Mn}$ & - & - & 0.006 & - & - & - & - & - \\
$\mathrm{Mg}$ & 0.996 & 0.982 & 0.927 & 0.956 & 0.957 & 0.963 & 0.982 & 0.954 \\
$\mathrm{Ca}$ & 0.788 & 0.759 & 0.739 & 0.727 & 0.695 & 0.814 & 0.788 & 0.677 \\
$\mathrm{Co}$ & - & 0.004 & - & - & - & - & 0.005 & - \\
$\mathrm{V}$ & - & - & - & - & 0.005 & 0.004 & - & 0.009 \\
$\mathrm{X}$ & 2.000 & 2.000 & 2.000 & 2.000 & 2.000 & 2.000 & 2.000 & 2.000 \\
$\mathrm{Y}$ & 1.197 & 1.230 & 1.237 & 1.248 & 1.291 & 1.186 & 1.196 & 1.215 \\
$\mathrm{Z}$ & 0.788 & 0.759 & 0.739 & 0.727 & 0.695 & 0.814 & 0.788 & 0.677 \\
$\mathrm{Mg} /(\mathrm{Mg}+\mathrm{Fe})$ & 86.0 & 84.5 & 84.0 & 83.0 & 80.2 & 86.1 & 86.8 & 80.2 \\
$\mathrm{Ca}$ & & & & & & & & \\
$\mathrm{Mg}$ & 41.5 & 39.5 & 38.8 & 38.7 & 36.8 & 42.2 & 41.1 & 36.3 \\
$\mathrm{Fe}$ & 50.3 & 51.1 & 51.4 & 50.9 & 50.7 & 49.8 & 51.2 & 51.1 \\
& 8.2 & 9.4 & 9.8 & 10.4 & 12.5 & 8.0 & 7.7 & 12.6 \\
\hline
\end{tabular}

$\mathrm{a}_{1}=$ Chrome-rich endiopsidic augite, resorbed grain $(200 \mu \mathrm{m})$ from Unit L3a $(\mathrm{C} 2)$. Sample $447 \mathrm{~A}-18-1,40 \mathrm{~cm}$;

2 = less chrome-rich, less magnesian resorbed endiopsidic augite, from same sample as Anal. 1; 3 = resorbed "transitional" endiopsidic augite (see text) containing glass inclusions, from Unit L3a (C2), Sample 447A-16-2, $45 \mathrm{~cm}$ :

$4=$ glomerophyric diopsidic augite from same sample as Anals. 1 and 2

$5=$ least magnesian diopsidic augite from same sample as Anals. 1, 2, and 4

6 = chrome-rich endiopsidic augite, resorbed grain $(500 \mathrm{pm})$ from Unit L3d (C3), Sample $447 \mathrm{~A}-22-1,20 \mathrm{~cm}$

7 = phenocryst of magnesian endiopsidic augite, Sample 449-15-1, $130 \mathrm{~cm}$

$8=$ iron-rich glomerocryst of diopsidic augite (same sample as Anal. 7).

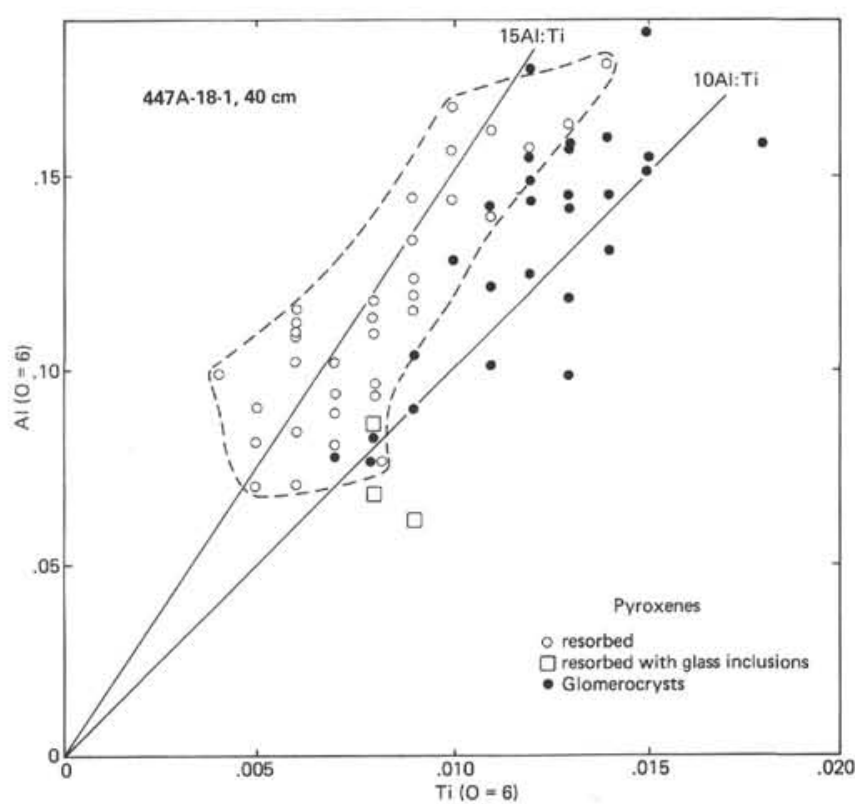

Figure 18. Comparison of aluminum and titanium contents (normalized to 6 oxygens) of pyroxene xenocrysts (open circles), glomerocrysts (closed circles), and crystals containing glass intrusions (squares) from Unit C2, Sample 447A-18-1, $40 \mathrm{~cm}$. 


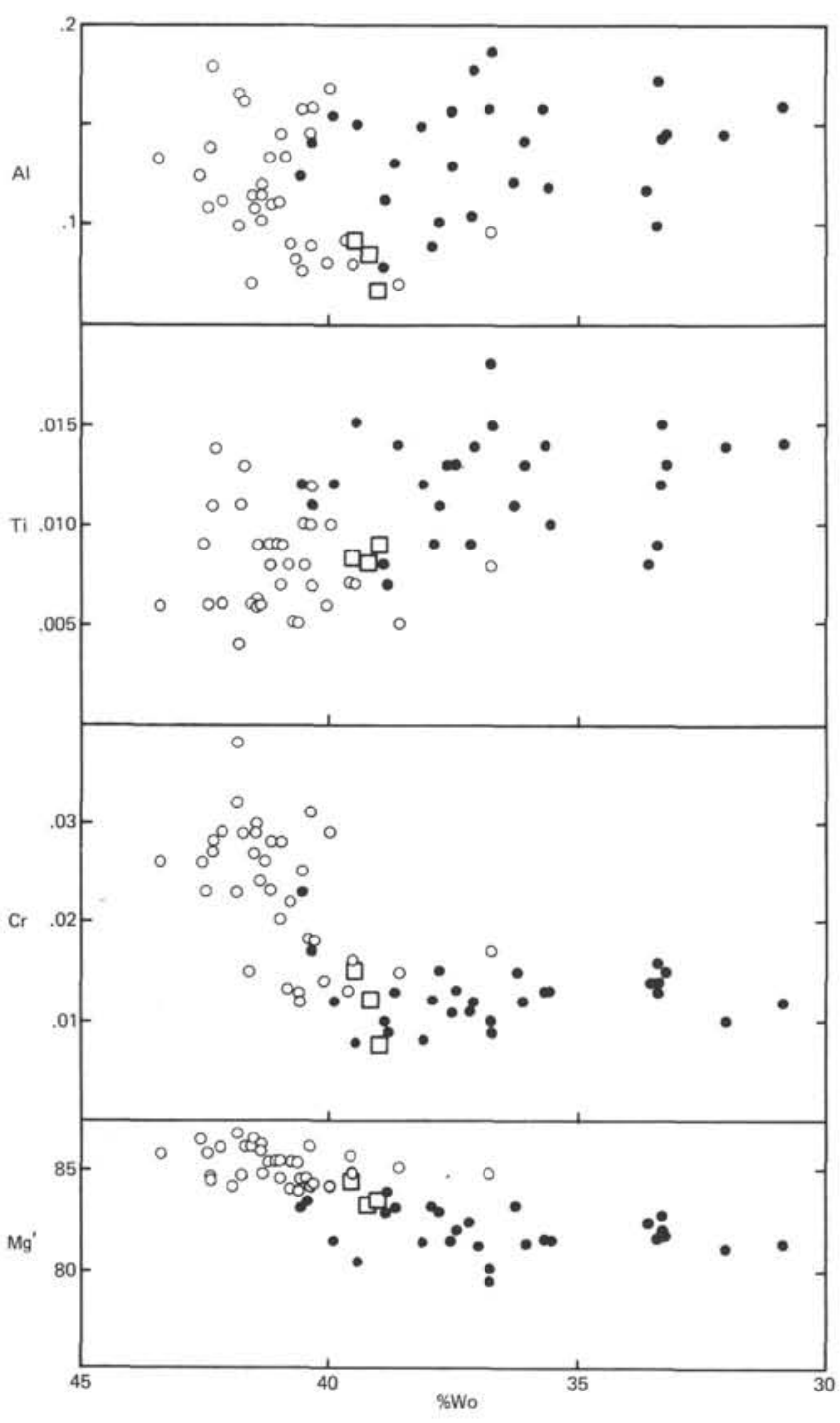

Figure 19. Variation in $\mathrm{Al}, \mathrm{Ti}, \mathrm{Cr}$, and $\mathrm{Mg}^{\prime}\left[\mathrm{Mg}^{2+} /\left(\mathrm{Mg}^{2+}+\mathrm{Fe}^{2+}\right)\right]$ (normalized to 6 oxygens) relative to wollastonite mole $\%$ in pyroxene xenocrysts and glomerocrysts. (The sample and symbols are the same as in Fig. 18.)

portion of the glassy selvage, however, contains colorless fresh glass veined by honey-yellow, slightly birefringent palagonite. Defocussed-beam microprobe analyses (Table 11) of the fresh glass (Analysis 1), palagonite (Analysis 2) and devitrification aureoles around microlites (Analyses 3, 4) are compared with the bulk-rock analysis of the pillow interior (Analysis 5). Comparing the fresh glass and bulk-rock analyses, the pillow interior is depleted in $\mathrm{SiO}_{2}$ and enriched $\mathrm{Na}_{2} \mathrm{O}^{2}$ and $\mathrm{K}_{2} \mathrm{O}$; smaller changes are observed in $\mathrm{FeO}$ (enriched) and in $\mathrm{MgO}$ and $\mathrm{CaO}$ (depleted). $\mathrm{TiO}_{2}$ and $\mathrm{Al}_{2} \mathrm{O}_{3}$ are essentially unchanged $\left(\mathrm{TiO}_{2}\right.$, in fact, is consistently about $10 \%$ lower in nearly all glasses relative to both fresh and altered whole-rock analyses; which may be a systematic analytic difference).

\footnotetext{
${ }^{2}$ Part of the $\mathrm{Na}_{2} \mathrm{O}$ difference may be the result of volatile loss during probe analysis.
}

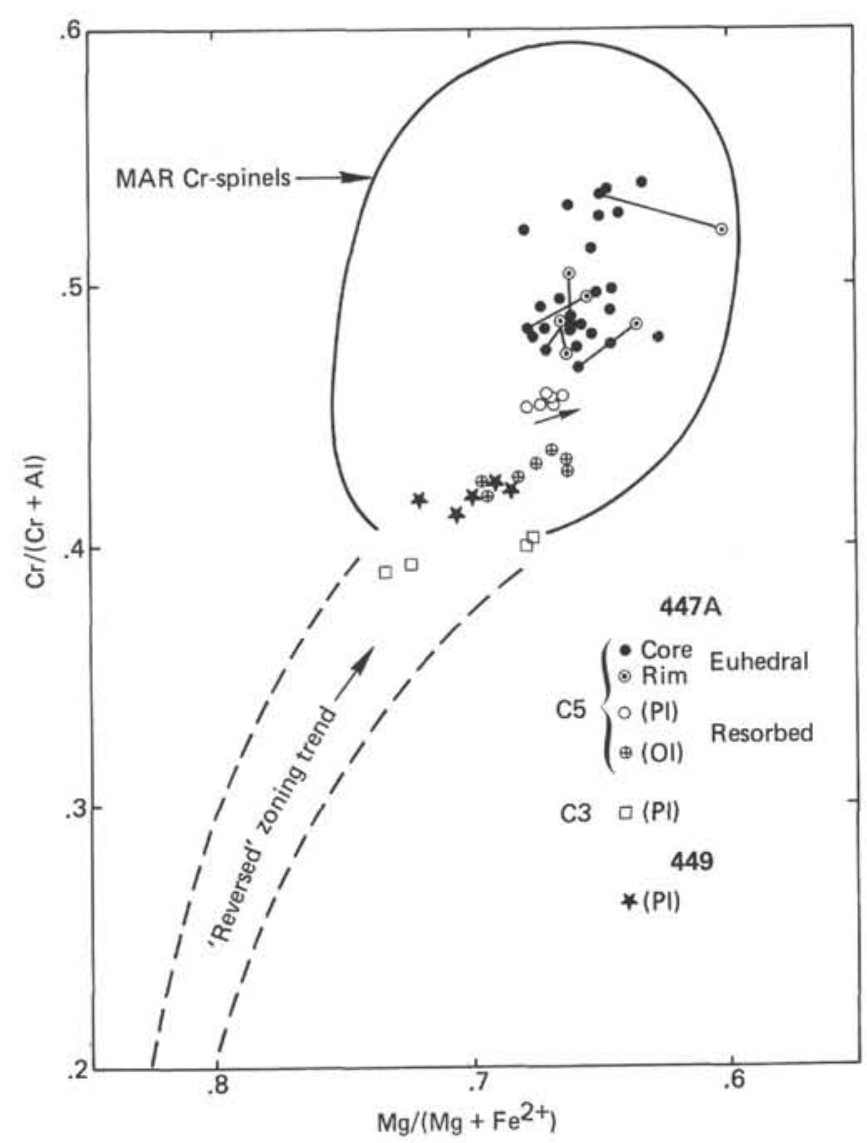

Figure 20. Composition of spinels in basalts from Holes 447A and 449 , plotted on the $[\mathrm{Cr} /(\mathrm{Cr}+\mathrm{Al})] /\left[\mathrm{Mg} /\left(\mathrm{Mg}+\mathrm{Fe}^{2+}\right)\right]$ face of the spinel prism. (The field of typical magnesiochromites from the Mid-Atlantic Ridge (MAR) is shown for comparison.)

The analyses of the devitrified glass are more variable, particularly in $\mathrm{MgO}$ (strongly depleted) and in $\mathrm{Al}_{2} \mathrm{O}_{3}$ and $\mathrm{CaO}$ (enriched). The inadvertent excitation of plagioclase microlites could also account for the increase of $\mathrm{Al}_{2} \mathrm{O}_{3}$ and $\mathrm{CaO}$ in these analyses. The greatest deviation in composition relative to the fresh glass is shown by the palagonite vein. The low total $(86 \%)$ suggests considerable hydration, and this is apparently accompanied by large losses in $\mathrm{CaO}$ and $\mathrm{Na}_{2} \mathrm{O}$. Smaller changes are shown by $\mathrm{MgO}$ and $\mathrm{SiO}_{2}$ (depleted), whereas $\mathrm{Al}_{2} \mathrm{O}_{3}$ and particularly $\mathrm{TiO}_{2}$ and $\mathrm{FeO}$ are enriched. The most dramatic change is shown by $\mathrm{K}_{2} \mathrm{O}$; enriched by a factor of 50 in the bulk-rock analysis, it is enriched by a factor of almost 200 in the palagonite vein. The chemical variations between fresh glass and palagonite are similar to those observed by Pritchard et al. (1979) for basalts from the Mid-Atlantic Ridge. They noted that the palagonite analyses recalculated to a dioctahedral illite composition and that the composition of the palagonite was probably controlled by crystal structure and depended on the chemistry of the fresh glass.

These results are probably typical of other glasswhole-rock major-element comparisons in Hole 447A basalts. The conclusion is that, with the notable excep- 
Table 10. Representative analyses of spinels.

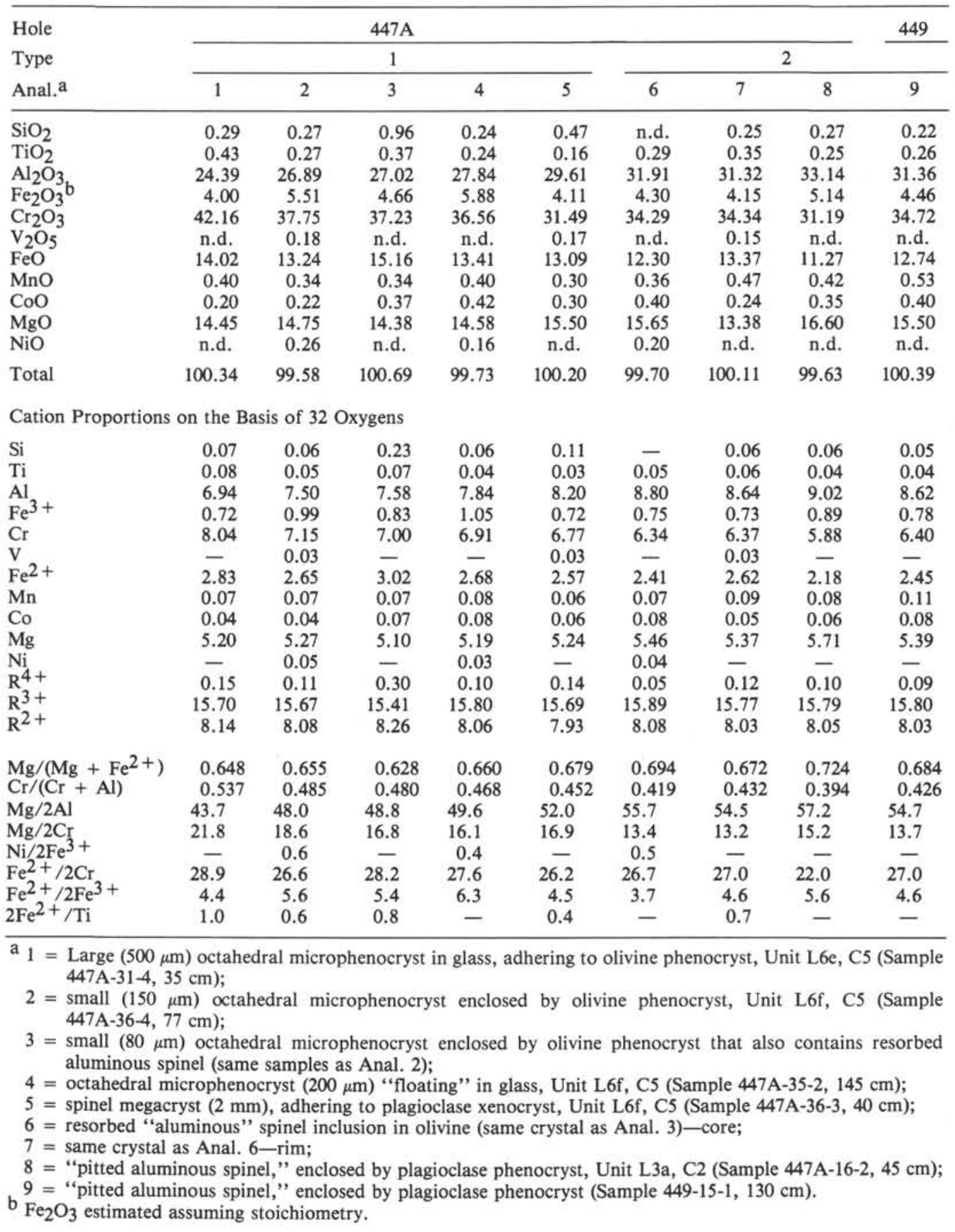

tion of $\mathrm{K}_{2} \mathrm{O}$ (and to a lesser extent $\mathrm{SiO}_{2}$ and $\mathrm{MgO}$, both of which are susceptible to alteration and varying proportions of cumulus phases), the XRF whole-rock major-element analyses are largely representative of the original pyrogenic compositions. Indeed, the XRF major-element data, when plotted on oxide- $\mathrm{MgO}$ variation diagrams (e.g., Fig. 19), form coherent trends with relatively little scatter.

It is generally agreed that $\mathrm{Cr}, \mathrm{Ni}, \mathrm{P}, \mathrm{Ti}, \mathrm{Zr}, \mathrm{Nb}$, and $\mathrm{Y}$ are relatively immobile during low-temperature alteration (Cann, 1970; Erlank and Kable, 1976), and these elements exhibit a strong covariance in basalts from Hole 447A (see Fig. 5, 6, 7, 10, and 11). However, there is no discernible correlation between these "immobile" elements and elements such as $\mathrm{Ba}$ and $\mathrm{Rb}$. Because these two elements do exhibit coherent variations with $\mathrm{Zr}, \mathrm{Nb}, \mathrm{Y}$, etc. in subaerial basalts (Weaver et al., 1979) and in less altered oceanic basalts (Tarney et al., 1979) it would appear that $\mathrm{Ba}$ and $\mathrm{Rb}$, like $\mathrm{K}$, have been mobile during alteration of Hole 447A basalts. Surprisingly, Sr varies coherently with $\mathrm{Zr}$ (Fig. 12) and appears to be relatively immobile (cf. Hart, 1970; Pearce and Cann, 1973), although this is not always the case during basalt alteration (Tarney et al., 1979). 
Table 11. Comparison of compositions of fresh glass, palagonite, devitrified glass, and crystalline interior of a single pillow.

\begin{tabular}{|c|c|c|c|c|c|}
\hline Anal. $^{\mathrm{a}}$ & 1 & 2 & 3 & 4 & 5 \\
\hline $\mathrm{SiO}_{2}$ & 51.2 & 42.3 & 50.5 & 51.5 & 48.8 \\
\hline $\mathrm{TiO}_{2}$ & 0.92 & 1.62 & 0.89 & 0.93 & 1.01 \\
\hline $\mathrm{Al}_{2} \overline{\mathrm{O}}_{3}$ & 15.5 & 17.1 & 18.9 & 16.7 & 15.3 \\
\hline $\mathrm{tFeO}^{\circ}$ & 8.63 & 13.97 & 9.11 & 7.95 & 9.53 \\
\hline $\mathrm{MnO}$ & 0.10 & 0.23 & 0.09 & 0.13 & 0.17 \\
\hline $\mathrm{MgO}$ & 8.44 & 5.52 & 3.05 & 7.96 & 7.51 \\
\hline $\mathrm{CaO}$ & 12.66 & 1.26 & 13.49 & 11.57 & 12.17 \\
\hline $\mathrm{Na}_{2} \mathrm{O}$ & 1.70 & 0.41 & 2.06 & 2.20 & 2.17 \\
\hline $\mathrm{K}_{2} \mathrm{O}$ & 0.02 & 3.82 & 0.41 & 0.76 & 1.03 \\
\hline $\mathrm{P}_{2} \mathrm{O}_{5}$ & - & - & - & - & 0.11 \\
\hline Total & 99.13 & 85.82 & 98.55 & 100.02 & 97.87 \\
\hline
\end{tabular}

$\mathrm{a}_{1}=$ Fresh glass;

2 = honey-yellow palagonite;

3 = mid-brown devitrified aureole around plagioclase microlite;

4 = dark brown devitrified pillow margin;

$5=$ whole-rock XRF analysis of pillow interior from Sample 447A-28-1, $140 \mathrm{~cm}$ (pillow margin), $112 \mathrm{~cm}$ (pillow interior).

The chemical changes resulting from seawater alteration of Hole 447A basalts are summarized in Table 12 and are compared qualitatively with the effects normally observed during low-temperature submarine weathering (Scott and Hajash, 1976; Thompson and Humphris, 1977).

\section{Discussion}

\section{Magmatic Processes at Site 447}

Clearly, basalts with a range of chemical and mineralogic compositions occur at Site 447. The results show, however, that on the basis of lithology, petrography, phenocryst compositions, glass compositions, and whole-rock major- and trace-element chemistry, the basalts can be grouped into five distinct chemical units. In this section we consider the nature of the magmatic processes that may have produced the chemical variations, both on an intra- and inter-unit scale.

\section{Intra-unit Chemical Variations}

Within each chemical unit, the XRF major-element analyses show a considerably greater dispersion than do the glasses. The whole-rock analyses are plotted on oxide-MgO variation diagrams together with the field of variation for each glass group in Figure 19. From these diagrams it is clear that the oxide deviating the most from the field of glass compositions for any particular group is $\mathrm{MgO}$. A significant, but smaller, spread of data is also observed for most other oxides. This blurring of the whole-rock analyses relative to the rather more consistent specific liquid composition is probably caused by two processes: (1) alteration, and (2) the uneven distribution and/or postextrusion gravitational settling of phenocrysts.

It is considered unlikely that alteration alone would modify, for example, the $\mathrm{MgO}$ content of these basalts by up to $3 \%$ (i.e., the same degree of leaching found in
Table 12. Chemical effects of low-temperature seawater alteration.

\begin{tabular}{lcc}
\hline & $\begin{array}{c}\text { Generally } \\
\text { observed }\end{array}$ & $\begin{array}{c}\text { Leg 59 } \\
\text { basalts }\end{array}$ \\
\hline $\mathrm{SiO}_{2}$ & -- & -- \\
$\mathrm{TiO}_{2}$ & $\mathrm{~N}+$ & $(+)$ \\
$\mathrm{Al}_{2} \mathrm{O}_{3}$ & +- & $(\mathrm{N})$ \\
$\mathrm{Fe}_{2} \mathrm{O}_{3}$ & + & $(+)$ \\
$\mathrm{FeO}$ & - & - \\
$\mathrm{MgO}$ & - & + \\
$\mathrm{CaO}$ & +- & +- \\
$\mathrm{Na} \mathrm{O}_{2}$ & + & -+ \\
$\mathrm{K}_{2} \mathrm{O}$ & ++ & ++ \\
$\mathrm{P}_{2} \mathrm{O}_{5}$ & $\mathrm{~N}$ & $\mathrm{~N}$ \\
$\mathrm{H} \mathrm{O}_{2}$ & + & + \\
$\mathrm{Cr}$ & $\mathrm{N}$ & $\mathrm{N}$ \\
$\mathrm{Ni}$ & $\mathrm{N}$ & $\mathrm{N}$ \\
$\mathrm{Rb}$ & ++ & ++ \\
$\mathrm{Sr}$ & ++ & $\mathrm{N}$ \\
$\mathrm{Y}$ & $\mathrm{N}$ & $\mathrm{N}$ \\
$\mathrm{Zr}$ & $\mathrm{N}$ & $\mathrm{N}$ \\
$\mathrm{Nb}$ & $\mathrm{N}$ & $\mathrm{N}$ \\
$\mathrm{Ba}$ & + & +- \\
$\mathrm{La}$ & $\mathrm{N}+$ & $\mathrm{N}$ \\
$\mathrm{Ce}$ & +- & $\mathrm{N}$ \\
$\mathrm{Nd}$ & $\mathrm{N}$ & $\mathrm{N}$ \\
$\mathrm{Pb}$ & + & + \\
$\mathrm{Th}$ & + & + \\
\hline
\end{tabular}

Note: $++=$ strong increase; $--=$ strong decrease; + $=$ slight increase; $-=$ slight decrease; ()$=$ slight change, within analytical error; $\mathrm{N}=$ no change.

${ }^{a}$ For data sources, see text.

the palagonitized glass, Table 9). Furthermore, intraunit variation is also observed in oxides $\left(\mathrm{TiO}_{2}, \mathrm{Al}_{2} \mathrm{O}_{3}\right)$ and elements $(\mathrm{Zr}, \mathrm{Y}, \mathrm{Sr})$ that are relatively insensitive to alteration.

The down-hole chemical stratigraphy diagrams (Fig. 4) show that a large proportion of the intra-unit variation is often found within a single flow. An additional source of intra-unit or, more particularly, intra-flow chemical variation would be caused by posteruptional gravitational settling of phenocrysts. This feature was noted by the shipboard scientists in the lower portions of the pillowed massive flows (e.g., Lithologic Units L3c, d; L4; L6a) and even within some of the larger pillows. Usually olivine (as smectite pseudomorphs) and, more rarely, plagioclase phenocrysts are asymmetrically distributed and are concentrated toward the base of the flow (or pillow). Analyses of basalts from various heights above the base of differentiated flow (L3d) are compared with the "parental" glass average for the chemical unit $(\mathrm{C} 3)$ in Table 13 . MgO increases from $6 \%$ at the top of the flow to over $9 \%$ in the central portion, where olivine phenocrysts (pseudomorphs) are concentrated, before falling to $\sim 7 \%$ at the base. $\mathrm{FeO}$ varies in the opposite sense, falling to a minimum at the center of the flow. The glass composition is intermediate relative to the two end members. Ni, which is strongly partitioned into olivine, covaries with $\mathrm{MgO}$, whereas ele- 
Table 13. Comparison of basalt compositions at four horizons (within flow Unit L3d, Hole 447A) with the "parental" glass average for Chemical Unit 3.

\begin{tabular}{lccccc}
\hline $\begin{array}{l}\text { Core-Section } \\
\text { Interval }(\mathrm{cm})\end{array}$ & $\begin{array}{c}22-1 \\
34\end{array}$ & $\begin{array}{c}22-3 \\
9\end{array}$ & $\begin{array}{c}23-1 \\
63\end{array}$ & $\begin{array}{c}23-4 \\
76\end{array}$ & Glass (av.), C3 \\
\hline $\mathrm{SiO}_{2}$ & 48.2 & 50.6 & 50.1 & 48.6 & 51.3 \\
$\mathrm{TiO}_{2}$ & 1.14 & 1.13 & 1.16 & 1.05 & 1.04 \\
$\mathrm{Al}_{2} \mathrm{O}_{3}$ & 14.7 & 14.5 & 14.7 & 14.8 & 14.9 \\
$\mathrm{tFeO}$ & 10.38 & 9.18 & 9.45 & 9.97 & 9.75 \\
$\mathrm{MnO}$ & 0.16 & 0.18 & 0.17 & 0.18 & 0.13 \\
$\mathrm{MgO}$ & 6.17 & 9.13 & 9.32 & 6.86 & 7.99 \\
$\mathrm{CaO}$ & 12.85 & 12.07 & 11.52 & 12.66 & 12.27 \\
$\mathrm{Na} 2 \mathrm{O}$ & 2.24 & 2.67 & 2.68 & 2.36 & 1.87 \\
$\mathrm{~K}_{2} \mathrm{O}$ & 0.99 & 0.06 & 0.06 & 0.59 & - \\
$\mathrm{P}_{2} \mathrm{O}_{5}$ & 0.19 & 0.08 & 0.08 & 0.08 & - \\
& & & & & -
\end{tabular}

Trace Elements (ppm)

\begin{tabular}{lrrrrl}
$\mathrm{Cr}$ & 276 & 253 & 226 & 279 & - \\
$\mathrm{Ni}$ & 113 & 143 & 112 & 107 & - \\
$\mathrm{Rb}$ & 9 & $<1$ & $<1$ & 5 & - \\
$\mathrm{Sr}$ & 78 & 69 & 69 & 71 & - \\
$\mathrm{Y}$ & 30 & 26 & 27 & 29 & - \\
$\mathrm{Zr}$ & 54 & 51 & 54 & 49 & - \\
$\mathrm{Nb}$ & 4 & 4 & 4 & 4 & - \\
$\mathrm{Ba}$ & 25 & 22 & 21 & 24 & - \\
$\mathrm{La}$ & 3 & 3 & 4 & 4 & - \\
$\mathrm{Ce}$ & 6 & 6 & 7 & 4 & - \\
$\mathrm{Nd}$ & 7 & 6 & 6 & 6 & - \\
$\mathrm{Th}$ & 1 & $<1$ & $<1$ & $<1$ & - \\
$\mathrm{Fe} /(\mathrm{Fe}+\mathrm{Mg})$ & 0.63 & 0.51 & 0.50 & 0.59 & 0.55 \\
$\mathrm{Ca} / \mathrm{Al}$ & 0.87 & 0.83 & 0.78 & 0.85 & 0.82 \\
$\mathrm{Ti} / \mathrm{Zr}$ & 127 & 133 & 129 & 128 & - \\
$\mathrm{Y} / \mathrm{Zr}$ & 0.55 & 0.51 & 0.51 & 0.59 & - \\
$\mathrm{Sr} / \mathrm{Zr}$ & 1.44 & 1.35 & 1.28 & 1.45 & - \\
$\mathrm{Cr} / \mathrm{Ni}$ & 2.4 & 1.8 & 2.0 & 2.6 & - \\
$\mathrm{Height}(\mathrm{m})^{\mathrm{a}}$ & 8.5 & 5.5 & 4.0 & 0.5 & - \\
\hline
\end{tabular}

${ }^{a}$ Height above base of flow unit.

ments with low distribution coefficients between olivine and melt (e.g., $\mathrm{Zr}, \mathrm{Y}, \mathrm{Sr}$, and $\mathrm{Cr}$ ) are diluted in the olivine cumulate zone.

In the major-element oxide- $\mathrm{MgO}$ variation diagrams (Fig. 21) for the whole-rock XRF data, it can be seen that the analyses from each unit form an overlapping series of subparallel trends which, in most diagrams, are related to an olivine control vector. Plots of Ti, Y, P (Figs. 5-7), and $\mathrm{Sr}$ versus $\mathrm{Zr}$ (Fig. 12) show that although ratios of these elements may differ between units, the variation within a particular chemical unit is characterized by a more or less constant ratio. Phenocryst/melt distribution coefficients $(D)$ for various minor and trace elements are compared in Table 14. Except for $\mathrm{Sr}, \mathrm{Ni}$, and $\mathrm{Cr}$, all these elements have $D \leqslant 1$, which means that the gravity differentiation of olivine or any other phenocrysts (except large quantities of clinopyroxene) will not significantly change ratios such as $\mathrm{Ti} / \mathrm{Zr}, \mathrm{Y} / \mathrm{Zr}$, or $\mathrm{P} / \mathrm{Y}$. Gravitational settling of olivine phenocrysts does, however, have a marked influence on $\mathrm{Ni}\left(D_{\mathrm{Ni}}^{\mathrm{O} / \text { iq }} \sim 10\right.$, Table 14$)$, which varies by as much as $50 \mathrm{ppm}$ within a single chemical unit (Fig. 10). On the other hand, $\mathrm{Sr}$, although controlled by plagioclase fractionation $\left(D_{\mathrm{S} r}^{\mathrm{PI}} /\right.$ iq $\sim 2$, Table 14), forms a linear positive correlation with $\mathrm{Zr}$ (Fig. 12) within each unit, which suggests that plagioclase settling was limited.
The existence of olivine cumulates can also be demonstrated using olivine-liquid $\mathrm{Fe}-\mathrm{Mg}$ equilibria. If the bulk-rock analyses are initially assumed to represent completely liquid compositions, then a set of apparent olivine-liquid $K_{D}$ values can be calculated using the expression given above. The representative (most magnesian) olivine-phenocryst compositions from each unit (Table 6) were used in the calculations and the results also plotted on Figure 15. It can be seen from the diagram that the apparent olivine-bulk-rock $K_{D}$ values form trends that pass through the field of olivine-glass $K_{D}$ values for that unit. Some whole-rock compositions from $\mathrm{Cl}$ and $\mathrm{C} 5$ have $K_{D}$ values in the same range as those of olivine glass. These rocks, although sparsely olivine and plagioclase phyric, could have been completely liquid at the time of eruption. Units $\mathrm{C} 2, \mathrm{C} 3$, and $\mathrm{C} 4$, however, contain whole-rock compositions that give anomalously high apparent $K_{D}$ values, ranging from 0.35 to 0.39 . These rocks are all relatively rich in olivine phenocrysts (or smectite pseudomorphs), and from lithologic evidence are interpreted as cumulates (because of gravitational settling after eruption). The high calculated $K_{D}$ values also support this interpretation, because the olivine phenocrysts found in the glasses are too low in Fo to be in equilibrium with a liquid of the composition of the whole rock.

It is suggested that the range of chemical variation found within each chemical unit in comparison to the glass analyses is caused mainly by the random sampling of slightly differentiated pillows and flows. Seawater alteration has also contributed to this variation, notably in the form of $\mathrm{K}_{2} \mathrm{O}, \mathrm{Rb}$, and $\mathrm{Ba}$ enrichment. Despite the altered nature of the samples analyzed, the XRF majorand trace-element data are remarkably coherent.

\section{Inter-unit Geochemical Variations}

The geochemical data show that essentially two independent fractionation trends link the five chemical groups of basalts in Hole $447 \mathrm{~A}$. The trends are principally defined by constant ratios of $\mathrm{Ti} / \mathrm{Zr}, \mathrm{Y} / \mathrm{Zr}$, and $\mathrm{P} / \mathrm{Zr}$. This implies that $\mathrm{C} 4$ basalts are comagmatic with $\mathrm{C} 1$ basalts and $\mathrm{C} 5$ basalts comagmatic with $\mathrm{C} 3$ and $\mathrm{C} 2$ basalts (Fig. 5-7). The abundances or behavior of many of the other elements analyzed characterize one or the other of these two fractionation trends. Thus the glasses of basalts with the lower $\mathrm{Ti} / \mathrm{Zr}, \mathrm{Y} / \mathrm{Zr}$, and $\mathrm{P} / \mathrm{Zr}$ ratios (i.e., Units $\mathrm{C} 1$ and $\mathrm{C} 4$ ), are less $\mathrm{Si}$-saturated, poorer in $\mathrm{SiO}_{2}$ and $\mathrm{CaO}$, and richer in $\mathrm{Al}_{2} \mathrm{O}_{3}$ and $\mathrm{Na}_{2} \mathrm{O}$ than are the glasses of basalts with the higher ratios (Units C2, $\mathrm{C} 3$, and $\mathrm{C} 5$ ). The XRF major-element variation is dominated by the effects of within-flow olivine settling, which tends to exaggerate the range of $\mathrm{MgO}$ contents found within each unit. Nevertheless the whole-rock major elements (e.g., $\mathrm{Al}, \mathrm{Ti}$, and $\mathrm{Na}$, Fig. 21) reflect the same inter-unit chemical differences as the glasses, despite some systematic discrepancies (caused by alteration or the different analytic methods used).

A good positive linear correlation that passes through zero between $\mathrm{Zr}$ and $\mathrm{Ti}$ or $\mathrm{Y}$ suggests that these elements are behaving as nearly ideal incompatible elements (Treuil and Varet, 1973). Basalt compositions that 


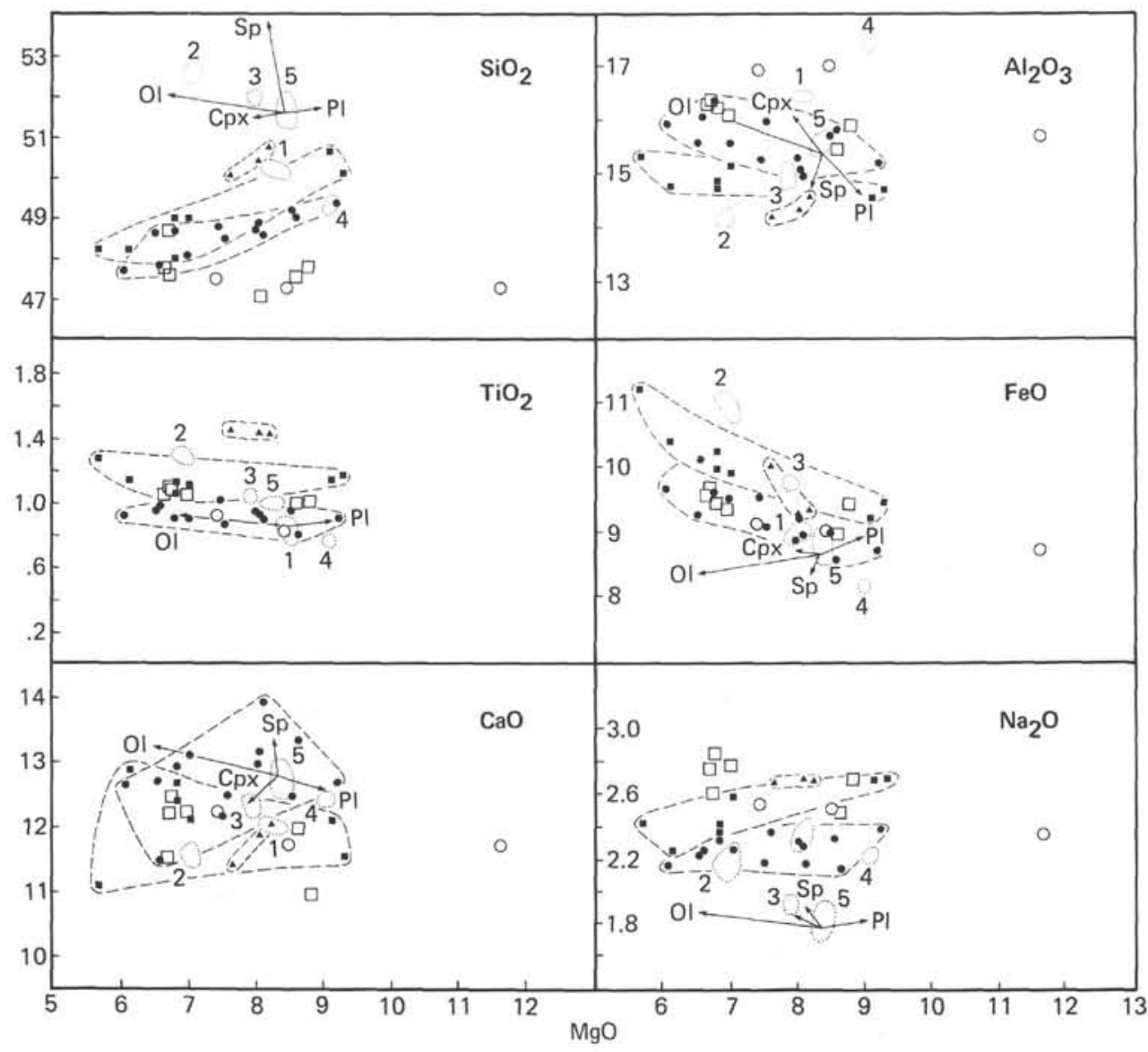

Figure 21. Major-element oxide-MgO variation diagrams for whole-rock XRF analyses from Hole 447A. (The symbols are identical to those in Fig. 5. The fields of basalt glass composition for each chemical unit are also plotted for comparison [labelled 1-5]. Heavy dashed lines emphasize the range of the compositions [XRF] found in Units C2, C3, and C5. Vectors illustrate the effect of removing $5 \%$ by weight of olivine $\left[\mathrm{Fo}_{85}\right]$, plagioclase $\left[\mathrm{An}_{85}\right]$, clinopyroxene $[\mathrm{Cr}$-rich endiopside, Table 9 , Analysis 2], and spinel [magnesiochromite, Table 10, Analysis 1].)

Table 14. Distribution coefficients $(D)$ for various minor and trace elements of phenocrysts and basaltic matrix and estimated coefficients for bulk mantle. ${ }^{\mathrm{a}}$

\begin{tabular}{lcccccccc}
\hline & $\mathrm{P}$ & $\mathrm{Ti}$ & $\mathrm{Zr}$ & $\mathrm{Y}$ & $\mathrm{Nb}$ & $\mathrm{Sr}$ & $\mathrm{Ni}$ & $\mathrm{Cr}$ \\
\hline Olivine & $0.01^{\mathrm{b}}$ & 0.01 & 0.01 & 0.01 & 0.01 & 0.01 & $10^{\mathrm{c}}$ & 0.2 \\
Plagioclase & $0.01^{\mathrm{b}}$ & 0.01 & 0.01 & 0.01 & 0.01 & 2.0 & 0.01 & 0.01 \\
Clinopyroxene & $0.1^{\mathrm{b}}$ & 0.5 & 0.1 & 0.7 & 0.01 & 0.12 & $2^{\mathrm{c}}$ & $2.5^{\mathrm{c}}$ \\
Garnet & $0.1^{\mathrm{b}}$ & - & 0.01 & 3.2 & 0.01 & 0.01 & - & - \\
Orthopyroxene & $0.01^{\mathrm{b}}$ & 0.1 & 0.03 & 0.2 & 0.15 & 0.02 & 3 & 5 \\
Bulk Mantle & 0.03 & 0.10 & 0.04 & 0.23 & 0.01 & 0.03 & 6.3 & 5.4 \\
\hline
\end{tabular}

a References: Arth and Hanson (1975); Drake (1976); Philpotts and Schnetzler (1970); Schnetzler and Philpotts (1970); and Pearce and Norry (1979).

$b$ Assumed values.

c Calculated for $T=1300^{\circ} \mathrm{C}$

$\mathrm{d} \mathrm{Ol}=50 \%, \mathrm{Cpx}=25 \%, \mathrm{Opx}=25 \%$.

define such a trend can realistically only be related by fractional crystallization of low-pressure basalt liquidus phases with very small distribution coefficients for these elements, such as olivine and plagioclase or minor clinopyroxene. Ti and $\mathrm{Y}$ are elements that are partitioned into clinopyroxene to a much greater extent than is $\mathrm{Zr}$ (Table 14), and more substantial precipitation of this phase (say greater than $10 \%$ ) produces a convex curvature to the $\mathrm{Ti} / \mathrm{Zr}$ and $\mathrm{Y} / \mathrm{Zr}$ trends (e.g., Deception Volcano, Tarney et al., 1977). The occurrence of $t w o$ such fractionation trends in a series of basalts closely related in space and time is particularly interesting. Clearly they cannot be derived from a common parent by the low-pressure fractional crystallization of the observed phenocryst phases. It is only possible to modify the $\mathrm{Ti} / \mathrm{Zr}, \mathrm{Y} / \mathrm{Zr}$, or $\mathrm{P} / \mathrm{Zr}$ ratios by substantial fractionation of clinopyroxene or, at high pressure, by fractionation of garnet.

The presence of partly redigested clinopyroxene xenocrysts in the more evolved basalts from the high $\mathrm{Ti} / \mathrm{Zr}$ trend is strong evidence that fractional crystallization of this phase indeed took place. We consider it unlikely, however, that basalts from each of the two trends are directly related by the fractionation of clinopyroxene. To change the $\mathrm{Ti} / \mathrm{Zr}$ ratio from 125 to 95 (Fig. 5) or the $\mathrm{Y} / \mathrm{Zr}$ ratio from 0.5 to 0.4 (Fig. 6) requires from $30 \%$ to $50 \%$ fractionation of clinopyroxene (calculated using the Rayleigh equation and the appropriate partition coefficients from Table 14). Furthermore, least-squares petrologic mixing calculations (see the material following) fail to account for differences in the major elements shown by the two magma types. The 
$\mathrm{SiO}_{2}$ - and $\mathrm{CaO}$-rich, $\mathrm{Al}_{2} \mathrm{O}_{3}$ - and $\mathrm{Na}_{2} \mathrm{O}$-poor basalts from Units $\mathrm{C} 2, \mathrm{C}_{1}$, and $\mathrm{C} 5$ cannot in any way be related to the $\mathrm{SiO}_{2^{-}}$and $\mathrm{CaO}$-poor, $\mathrm{Al}_{2} \mathrm{O}_{3}$ - and $\mathrm{Na}_{2} \mathrm{O}$-rich basalts from Units $\mathrm{C} 1$ and $\mathrm{C} 4$ by fractional crystallization of clinopyroxene. Garnet fractionation is also unsatisfactory, as even minor precipitation of garnet would severely deplete an element such as $\mathrm{Y}$, which, like the heavy rare-earth elements, is strongly partitioned into this phase (Table 14).

Alternatively, a partial melting process could generate parental compositions with different initial traceelement abundances, either as a result of melting of different source compositions or through different degrees of partial melting of the same source. In the absence of isotope and rare-earth element data it is difficult to constrain these two models. The behavior of elements with extremely small bulk solid/liquid partition coefficients (i.e., $D<0.01$, such as $\mathrm{La}, \mathrm{Ce}, \mathrm{Ta}, \mathrm{Nb}, \mathrm{Hf}$, Th) has proved effective in recognizing varying scales of mantle -inhomogeneity in the North Atlantic (Wood, Tarney et al., 1979; Tarney et al., 1979). Without precise data for these elements, the possibility of local mantle heterogeneity cannot be excluded.

If clinopyroxene were to remain as a residual phase during partial melting, then elements such as $\mathrm{Ti}$ and $\mathrm{Y}$ would be progressively retained in the source with smaller degrees of melting. Residual clinopyroxene in the mantle source region beneath the spreading axis is not an unreasonable assumption. Thus different degrees of melting of the same source could generate parental basalts with different $\mathrm{Ti} / \mathrm{Zr}, \mathrm{Y} / \mathrm{Zr}$, and $\mathrm{P} / \mathrm{Zr}$ ratios. Bulk mantle/liquid distribution coefficients for a selection of elements for a hypothetical three-phase mantle $(50 \%$ olivine $+25 \%$ clinopyroxene $+25 \%$ orthopyroxene) are also listed in Table 14. Although the values are only approximate, the important point is that the bulk mantle distribution coefficients for Ti and $\mathrm{Y}$ would almost certainly be larger than that for $\mathrm{Zr}$. Therefore the locus of a series of liquids generated by variable partial melting of a mantle containing residual clinopyroxene would be a curved line on a plot of Y (or Ti) versus $\mathrm{Zr}$ (Fig. 22). Subsequent fractional crystallization of olivine, plagioclase, or minor clinopyroxene would then produce the two linear trends extending away from the origin (Treuil and Varet, 1973; Tarney et al., 1979).

The least-squares petrologic mixing equation of Wright and Doherty (1970) has been used to test whether basalts from different units lying along these trends could be related by closed-system low-pressure fractional crystallization. Mixing problems were set up that attempted to relate a primitive parental basalt unit with a more evolved unit by the subtraction of reasonable phenocryst assemblages. For any result to be valid, it is critical that the compositions used in the calculations were entirely liquid prior to eruption. For this reason, and for their superior freshness, the average glass compositions from each chemical unit (Table 5) were used (recalculated to total $100 \%, \mathrm{~K}_{2} \mathrm{O}$-free). Relevant phenocryst compositions were selected from the microprobe data. A solution is considered potentially valid if the oxide residuals are less than 0.1 (especially

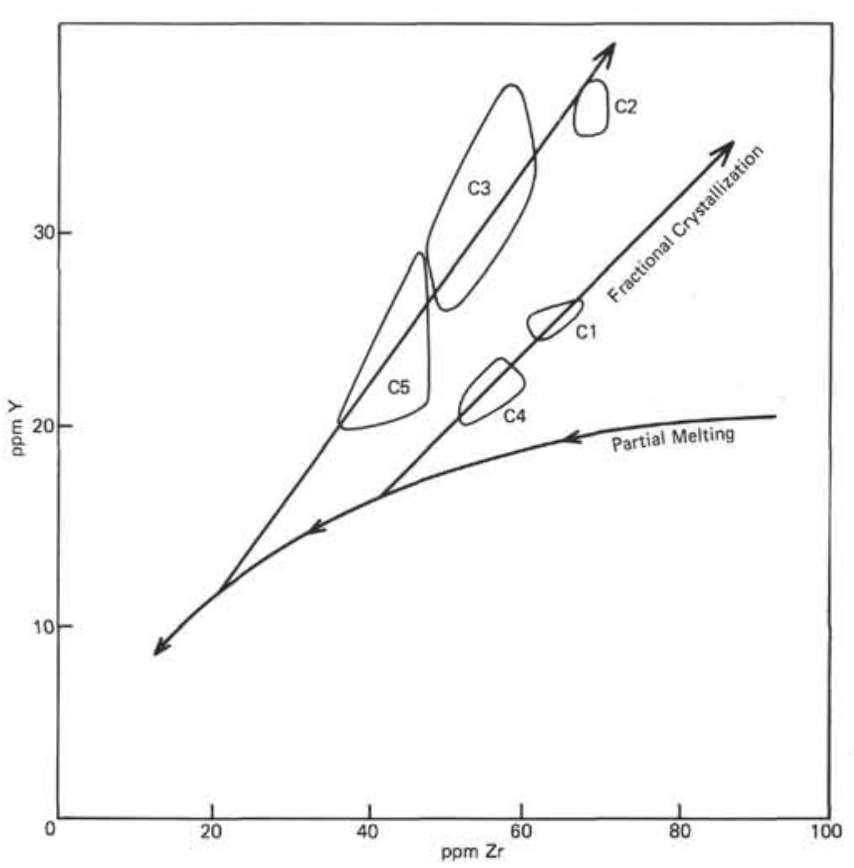

Figure 22. Compositional fields of the five chemical units from Hole $447 \mathrm{~A}$ plotted on a yttrium-zirconium diagram to illustrate possible inter-unit relationships by partial melting and fractional crystallization.

for $\mathrm{TiO}_{2}$ ), the sum of the squares of the residuals is close to or less than 0.1 (Wright, 1974), and above all, if the amounts and compositions of the subtracted phases are compatible with the petrographic data.

The most primitive basalts, in terms of $\mathrm{FeO} /(\mathrm{FeO}+$ $\mathrm{MgO}$ ) and low abundances of the incompatible elements, belong to Unit $\mathrm{C} 4$ for the low $\mathrm{Y} / \mathrm{Zr}$ magma type and Unit $\mathrm{C} 5$ for the higher $\mathrm{Y} / \mathrm{Zr}$ magma type.

The derivation of $\mathrm{Cl}$ basalts from the more-primitive C4 basalts can be satisfactorily accomplished by $16 \%$ crystallization of plagioclase $\left(\mathrm{An}_{85}\right)$, olivine $\left(\mathrm{Fo}_{88}\right)$, and minor clinopyroxene in the proportions $5: 1.5: 1$. The results of this calculation are set out in Table 15. The amount of crystallization can also be calculated from the enrichment or depletion of elements such as $\mathrm{Ti}, \mathrm{Y}$, $\mathrm{Zr}, \mathrm{Ni}$, and $\mathrm{Sr}$ in the derived basalts using the Rayleigh fractionation law:

$$
\frac{C^{1}}{C^{0}}=(1-F)^{(1-D)}
$$

(where $C^{\circ}=$ concentration in parent liquid, $C^{1}=$ concentration in derived liquid, $F=$ fraction of solids removed, and $D=$ bulk distribution coefficient). A bulk partition coefficient was calculated for the fractionating assemblage using the phase proportions predicted by the major-element fractionation model. The average abundances (from Table 5) of the elements listed above in the parental and derived units were used to calculate the quantity of solid phases removed to satisfy the observed enrichment or depletion. These results are compared with those from the major-element mixing calculations in Table 16. 
Table 15. Least-squares crystal fractionation solution between Chemical Units $\mathrm{C} 1$ and $\mathrm{C} 4$.

\begin{tabular}{lcccrrrr}
\hline & $\begin{array}{c}\text { Derivative } \\
\mathrm{Cl}\end{array}$ & $\begin{array}{c}\text { Plag } \\
\text { An85 }\end{array}$ & $\begin{array}{c}\text { Ol } \\
\text { Fo88 }\end{array}$ & \multicolumn{1}{c}{$\mathrm{Cpx}$} & $\begin{array}{c}\text { Parent } \\
\mathrm{C} 4\end{array}$ & $\begin{array}{c}\text { Calc. } \\
\mathrm{C} 4\end{array}$ & Residuals \\
\hline $\mathrm{SiO}_{2}$ & 50.20 & 47.28 & 40.11 & 53.86 & 49.60 & 49.64 & 0.04 \\
$\mathrm{TiO}_{2}$ & 1.00 & - & - & 0.31 & 0.73 & 0.84 & 0.11 \\
$\mathrm{Al}_{2} \mathrm{O}_{3}$ & 16.60 & 32.98 & - & 2.49 & 17.43 & 17.41 & -0.01 \\
$\mathrm{tFeO}$ & 9.21 & - & 11.40 & 4.36 & 8.29 & 8.21 & -0.08 \\
$\mathrm{MnO}$ & 0.09 & - & 0.23 & 0.19 & 0.10 & 0.09 & -0.01 \\
$\mathrm{MgO}$ & 8.46 & - & 47.00 & 17.54 & 9.16 & 9.15 & -0.01 \\
$\mathrm{CaO}$ & 12.02 & 16.93 & 0.27 & 20.69 & 12.39 & 12.32 & -0.07 \\
$\mathrm{Na}_{2} \mathrm{O}$ & 2.47 & 1.68 & - & - & 2.25 & 2.24 & -0.01 \\
Solution & 0.837 & 0.105 & 0.035 & 0.023 & & & \multicolumn{2}{c}{$\mathrm{rr}^{2}=0.03$} \\
\hline
\end{tabular}

Note: The solution suggests that Unit $\mathrm{Cl}$ may be derived from Unit $\mathrm{C} 4$ by $16.3 \%$ crystal fractionation of a mineral assemblage-plagioclase $64.4 \%$, olivine $21.5 \%$, clinopyroxene $14.1 \%$.

In the $\mathrm{C} 4$ to $\mathrm{C} 1$ fractionation step, the amounts of crystallization predicted by the enrichment of $\mathrm{Ti}, \mathrm{Zr}$, and $\mathrm{Y}$ and the depletion of $\mathrm{Ni}$ are in good agreement with the amount predicted by the difference in majorelement compositions of the glasses. However, $\mathrm{Sr}$ increases from $111 \mathrm{ppm}$ in Unit C4 to $131 \mathrm{ppm}$ in Unit C1 and correlates positively with $\mathrm{Zr}$ (Fig. 12). Because $\mathrm{Si}$ is usually thought to partition strongly into plagioclase $\left(D_{\mathrm{Sr}}^{\mathrm{pl} / \mathrm{iq}} \sim 1.87\right.$, Drake and Weill, 1975), plagioclasedominated fractional crystallization, as suggested by the least-squares calculation, should deplete the melt in $\mathrm{Sr}$ to a greater extent than is observed. The enrichment of $\mathrm{Sr}$ in the more fractionated basalts would require $D_{\mathrm{Sr}}^{\mathrm{pl} / \mathrm{iq}}$ to be $\sim 0.05$. The validity of the fractionation model is then questioned by the unexpected behavior of Sr. The results of the least-squares calculations on undoubted liquid compositions are good, with low-oxide residuals. Also, the modal proportions of plagioclase, olivine, and minor clinopyroxene are similar to the abundances of these phases found as phenocrysts in the basalts. The weakest point of the model lies in the use of the average trace-element abundances measured in whole-rock samples that may not have been completely liquid when erupted. Minor accumulation of plagioclase could significantly increase the whole-rock $\mathrm{Sr}$ in liquids with such low $\mathrm{Sr}$ contents $(\sim 120 \mathrm{ppm})$. Fe-Mg olivine-liquid equilibria suggest that this may be true in the case of one sample from C4 (see Fig. 15 and related text). Biased sampling of olivine-rich basalts (resulting from gravitational settling) from Unit C4 and/or plagioclase-rich basalts from Unit $\mathrm{C} 1$ may account for the approximately $20 \%$ enrichment of $\mathrm{Sr}$ observed in whole-rock analyses of Unit $\mathrm{C} 1$ relative to Unit $\mathrm{C} 4$.

Tables 17 and 18 present results of least-squares fractionation calculations between pairs of the three chemical units that have the high $\mathrm{Ti} / \mathrm{Zr}-\mathrm{Y} / \mathrm{Zr}$ fractionation trend (see Figs. 5 and 6). Using the average glass composition from Unit $\mathrm{C} 5$ as a prospective parental composition, fractionation steps to $\mathrm{C} 3$ and $\mathrm{C} 2$ basalts give numerically satisfactory results. The differences in major elements between these units can be related by fractional crystallization of plagioclase, olivine, and clinopyroxene (in proportions approximately $5: 1: 4$ ) in two steps of $17 \%$. The fractionation of clinopyroxene appears to be more important in the evolution of the basalts from this magma type.

Comparing the degrees of fractionation calculated from the trace elements with those predicted by the major elements within this magma type reveals some variance, notably for $\mathrm{Sr}$ and $\mathrm{Ni}$. The Rayleigh fractionation results for $\mathrm{Ti}, \mathrm{Y}$, and $\mathrm{Zr}$ between $\mathrm{C} 5$ and $\mathrm{C} 3$ and between C5 and C2 (Table 16) are in fairly good agreement with the degree of fractionation required to account for the differences in major elements. The $17 \%$ subtraction of plagioclase, olivine, and clinopyroxene (in proportions 5:1:4) to derive $\mathrm{C} 3$ from $\mathrm{C} 5$ basalts explains the observed depletion of $\mathrm{Ni}$, but the observed depletion of $\mathrm{Sr}$, as indicated by the average abundances in each unit, is too severe. On the other hand, the differences in $\mathrm{Ni}$ and $\mathrm{Sr}$ between $\mathrm{C} 5$ and $\mathrm{C} 2$ basalts are too small to be satisfactorily explained by $34 \%$ fractionation of the assemblage predicted by the least-squares calculations. Again, the accumulation of olivine or plagioclase phenocrysts in the whole-rock samples could account for anomalous inter-unit differences in $\mathrm{Sr}$ and $\mathrm{Ni}$. Moreover, many flows of this magma type contain xenocrysts, particularly basalts from the lower parts of Unit $\mathrm{C} 5$ and from Unit C2.

The presence of these xenocrysts could contribute to unsatisfactory fractional crystallization model in two ways. The actual analysis of xenocrystic rock may result in chemical bias. A more fundamental implication is that the presence of xenocrysts reflects the possibility that magmatic processes other than closed-system fractional crystallization may have taken place, such as magma mixing.

Table 16. Fractional crystallization models for Site 447 basalts.

\begin{tabular}{|c|c|c|c|c|c|c|c|c|c|c|c|c|c|c|}
\hline \multirow{3}{*}{$\begin{array}{l}\text { Parent } \\
\text { magma } \\
\text { type }\end{array}$} & \multirow{3}{*}{$\begin{array}{c}\text { Derivative } \\
\text { magma } \\
\text { type }\end{array}$} & \multicolumn{8}{|c|}{$\underline{\text { Least-squares models for major elements }}$} & \multirow{2}{*}{\multicolumn{5}{|c|}{$\begin{array}{c}F^{\mathrm{b}} \text { from Rayleigh } \\
\text { fractionation models }\end{array}$}} \\
\hline & & \multicolumn{4}{|c|}{ Glass } & \multicolumn{4}{|c|}{ Whole rock } & & & & & \\
\hline & & Ol & Plag & Pyx & $\mathrm{F}^{\mathrm{a}}$ & $\mathrm{Ol}$ & Plag & Pyx & $\mathrm{F}^{\mathrm{a}}$ & $\mathrm{Ti}$ & $\mathrm{Zr}$ & $\mathrm{Y}$ & $\mathrm{Ni}$ & $\mathrm{Sr}$ \\
\hline $\mathrm{C} 4$ & $\mathrm{Cl}$ & 3.5 & 10.5 & 2.3 & $16.3 \%$ & 5.4 & 8.3 & 0.8 & & 15.0 & 12.5 & 13.2 & 17.0 & - \\
\hline C5 & $\mathrm{C} 3$ & 1.7 & 8.9 & 6.9 & $17.6 \%$ & 1.3 & 8.3 & 4.1 & $13.7 \%$ & 23.5 & 13.8 & 23.1 & 25.2 & - \\
\hline C5 & $\mathrm{C} 2$ & 4.0 & 17.9 & 12.5 & $34.3 \%$ & 0.5 & 8.9 & 2.4 & $11.8 \%$ & 41.3 & 34.5 & 43.0 & 9.0 & 25.8 \\
\hline
\end{tabular}

${ }^{\mathrm{a}} \mathrm{F}$ refers to the percentage fractional crystallization (of the mineral proportions indicated) calculated to relate derivative and parent-magma major-element compositions, based on glass and whole-rock analyses, respectively.

b $F$ refers to the percentage fractional crystallization necessary to produce the observed changes in the trace-element abundances, based on the Rayleigh fractionation equation. For Ti, Zr, Y, Ni, and $\mathrm{Sr}$, bulk distribution coefficients have been calculated for the mineral assemblages predicted by the respective glass analyses (see Table 14). 
Table 17. Least-squares crystal fractionation solution between Chemical Units C3 and C5.

\begin{tabular}{|c|c|c|c|c|c|c|c|}
\hline & $\begin{array}{c}\text { Derivative } \\
\text { C3 }\end{array}$ & $\begin{array}{l}\text { Plag } \\
\text { An80 }\end{array}$ & $\begin{array}{c}\text { Ol } \\
\text { Fo85 }\end{array}$ & Cpx & $\begin{array}{c}\text { Parent } \\
\text { C5 }\end{array}$ & $\begin{array}{c}\text { Calc. } \\
\text { C5 }\end{array}$ & Residuals \\
\hline $\mathrm{SiO}_{2}$ & 51.50 & 49.87 & 40.01 & 53.86 & 51.80 & 51.65 & -0.15 \\
\hline $\mathrm{TiO}_{2}$ & 1.01 & - & - & 0.31 & 0.87 & 0.86 & -0.01 \\
\hline $\mathrm{Al}_{2} \mathrm{O}_{3}$ & 15.10 & 32.08 & - & 2.49 & 15.50 & 15.59 & -0.09 \\
\hline $\mathrm{FeO}$ & 9.78 & 0.50 & 13.94 & 4.36 & 8.48 & 8.71 & 0.23 \\
\hline $\mathrm{MnO}$ & 0.13 & - & - & 0.19 & 0.12 & 0.12 & 0.00 \\
\hline $\mathrm{MgO}$ & 8.06 & - & 40.40 & 17.54 & 8.61 & 8.67 & 0.06 \\
\hline $\mathrm{CaO}$ & 12.44 & 15.57 & 0.32 & 20.69 & 12.89 & 13.16 & 0.27 \\
\hline $\mathrm{Na}_{2} \mathrm{O}$ & 1.95 & 2.11 & - & - & 1.76 & 1.81 & 0.05 \\
\hline Solution & 0.830 & 0.089 & 0.017 & 0.069 & & & $\Sigma r^{2}=0.16$ \\
\hline
\end{tabular}

Note: The solution suggests that Unit C 3 may be derived from Unit C 5 by $17 \%$ crystal fractionation of a mineral assemblage-plagioclase $50.9 \%$, olivine $9.5 \%$, clinopyroxene $39.4 \%$.

Table 18. Least-squares crystal fractionation solution between Chemical Units $\mathrm{C} 2$ and $\mathrm{C} 5$.

\begin{tabular}{lccccrrr}
\hline & $\begin{array}{c}\text { Derivative } \\
\mathrm{C} 2\end{array}$ & $\begin{array}{c}\text { Plag } \\
\text { An80 }\end{array}$ & $\begin{array}{c}\text { Ol } \\
\text { Fo85 }\end{array}$ & \multicolumn{1}{c}{ Cpx } & $\begin{array}{c}\text { Parent } \\
\text { C5 }\end{array}$ & $\begin{array}{c}\text { Calc. } \\
\text { C5 }\end{array}$ & Residuals \\
\hline $\mathrm{SiO}_{2}$ & 52.50 & 49.87 & 39.40 & 53.86 & 51.80 & 51.80 & 0.00 \\
$\mathrm{TiO}_{2}$ & 1.25 & - & - & 0.31 & 0.87 & 0.86 & -0.01 \\
$\mathrm{Al}_{2} \mathrm{O}_{3}$ & 14.33 & 32.08 & - & 2.49 & 15.50 & 15.49 & -0.01 \\
$\mathrm{FeO}$ & 10.84 & 0.50 & 16.89 & 4.36 & 8.48 & 8.45 & -0.03 \\
$\mathrm{MnO}$ & 0.12 & - & 0.22 & 0.19 & 0.12 & 0.11 & -0.01 \\
$\mathrm{MgO}$ & 7.19 & - & 42.61 & 17.54 & 8.61 & 8.62 & 0.01 \\
$\mathrm{CaO}$ & 11.38 & 15.57 & 0.29 & 20.69 & 12.89 & 12.88 & -0.01 \\
$\mathrm{Na} 2 \mathrm{O}$ & 2.32 & 2.11 & - & - & 1.76 & 1.91 & 0.15 \\
Solution & 0.659 & 0.178 & 0.040 & 0.125 & & & $2 \mathrm{r}^{2}=0.02$ \\
\hline
\end{tabular}

Note: The solution suggests that Unit C2 may be derived from Unit C5 by $34.1 \%$ crystal fractionation of a mineral assemblage-plagioclase $51.9 \%$, olivine $11.7 \%$, clinopyroxene $36.4 \%$.

\section{Origin of the Xenocrysts}

Xenocrysts are found only in basalts corresponding to the high $\mathrm{Ti} / \mathrm{Zr}$ and high $\mathrm{Y} / \mathrm{Zr}$ magma type and are most common in the lower basalts from Unit $\mathrm{C} 5$ and in Unit $\mathrm{C} 2$ basalts. Examples of olivine, plagioclase, clinopyroxene, and spinel xenocrysts have been recognized, although not all of these phases are necessarily found in the same basalt flow. Unit C5 basalts are characterized by chromian-spinel xenocrysts that are more aluminous than the magnesiochromite phenocrysts and by plagioclase xenocrysts (usually less calcic than associated plagioclase phenocrysts). Unit $\mathrm{C} 2$ basalts contain xenocrysts similar to those found in C5 basalts as well as olivines that are more magnesian than the associated phenocrysts, plagioclase more calcic than the plagioclase phenocrysts, and $\mathrm{Cr}$-rich endiopsides.

Many occurrences of similar xenocrysts or megacrysts have been reported in drilled basalts from the Mid-Atlantic Ridge (e.g., Leg 2, Frey, Bryan et al., 1974; Leg 37, Donaldson, Brown et al., 1977; Legs 45 and 46, Dungan and Rhodes, 1978; FAMOUS Area, Melson, 1979). Megacrysts are rare in the evolved Ferich basalts from the East Pacific Rise. Hypotheses put forward to explain the origin of these exotic phases include:

1) accidental disturbance of cumulate material within a magma chamber (Muir and Tilley, 1964);

2) resorption of cognate low-pressure phenocrysts caused by rapid changes in conditions, such as pressure or volatile content (Aumento, 1964; Melson et al., 1968);

3) resorption of cognate crystals carried down to hotter portions of magma chambers by convective overturns (Melson and Thompson, 1971); and

4) accidental or cognate fragments of the upper mantle (Blanchard et al., 1976).

The xenocrysts from Hole 447A can be classified into two types, according to the type of liquid from which they might originally have crystallized: (1) "morerefractory" xenocrysts, crystallized from a more primitive (Mg-, Ca-rich) liquid than the host rock, and (2) "less-refractory" xenocrysts, crystallized from a more evolved (Mg-, Ca-poor) liquid than the host rock. The more-refractory xenocrysts include magnesian olivines (C2), calcic plagioclases (C2), and aluminum chromianspinels (C2, C5); less-refractory xenocrysts include lesscalcic plagioclase $(\mathrm{C} 2, \mathrm{C} 5)$ and $\mathrm{Cr}$-rich endiopsides $(\mathrm{C} 2$, rarely in C3).

There is no evidence that any of these phases crystallized at high (mantle) pressures. Shearing, kinkbanding, or any other physical deformations are notably absent, particularly in the olivine crystals. With the exception of the less-calcic plagioclase xenocrysts, all other crystals are single grains. Thus the xenocrysts are not thought to have originated as accidental inclusions of upper-mantle or lower oceanic-crust material. The $\mathrm{CaO}$ contents of the olivines are typical of olivine crystallized at relatively low pressures (Simkin and Smith, 1970); the endiopsides have low $\mathrm{Al}_{2} \mathrm{O}_{3}$ contents and do not in any way resemble the highly aluminous clinopyroxenes $\left(6-10 \% \quad \mathrm{Al}_{2} \mathrm{O}_{3}\right)$ crystallized from tholeiitic basalts at 10 to $18 \mathrm{~kb}$ (Thompson, 1974). The resorbed chromian-spinel xenocrysts, however, are similar to the aluminous spinels from Mid-Atlantic Ridge basalts interpreted by Dick (1976) and Sigurdsson (1976) as having crystallized at elevated pressures, possibly during residence in subcrustal magma chambers.

Xenoliths of cumulate anorthosite are also present in the lower basalts from Unit C5 and are associated with xenocrysts of less-calcic plagioclase. The abraded morphology of these less-calcic plagioclases and their similarity to those that make up the anorthosite xenoliths suggest that they are both derived from the same source. It seems likely that the less-calcic plagioclase, the olivine, and the endiopside xenocrysts (i.e., the lessrefractory xenocrysts) have resulted from accidental disturbance of crystal cumulates within a sub-axis magma chamber. The chromian-spinels and the more-calcic plagioclase may have crystallized at slightly higher pressures, perhaps prior to injection into a sub-axis magma chamber.

The association of more-refractory xenocrysts with less-refractory xenocrysts in the $\mathrm{C} 2$ basalts suggests that the new influx of Ca-plagioclase- and $\mathrm{Al}$-spinel-bearing primitive magma disturbed cumulate material that had separated from a more evolved magma already resident in the magma chamber. The resultant hybrid magma must have erupted before the two sets of xenocrysts had 
time to equilibrate fully with the new host magma composition.

\section{Summary of Magmatic History at Site 447}

The magmatic history of the basalts erupted at Hole 447A can be interpreted as follows:

1) Eruption of $\mathrm{C} 5$ basalt from a magma chamber that had been fractionating plagioclase. The eruption was probably triggered by an influx from below of primitive $\mathrm{Al}$-spinel-bearing magma (with high $\mathrm{Ti} / \mathrm{Zr}$, etc.). Early basalts contained xenocrysts of $\mathrm{Al}$-rich spinel (chromian spinel) and xenoliths of cumulate anorthosite. As the magma chamber became more quiescent, later basalts were xenocryst- and xenolithfree.

2) Eruption of $\mathrm{C} 4$ basalts (with lower $\mathrm{Ti} / \mathrm{Zr}$ ) as a separate magma batch from the mantle. This event represented either a smaller degree of partial melting of the same magma source or derivation from a slightly different source composition. The magmatic plumbing system must have been quite separate from the one used for the passage and storage of $\mathrm{C} 5$ basalts.

3) Eruption of C3 basalts derived from a C5-type magma by fractional crystallization of $8.9 \%$ plagioclase, $1.7 \%$ olivine, and $6.9 \%$ clinopyroxene.

4) Eruption of $\mathrm{C} 2$ basalts, probably triggered by a fresh influx of $\mathrm{Al}$-spinel- and Ca-plagioclase-bearing primitive magma. Resulting magma contained these xenocrysts and less-calcic plagioclase, olivine(?), and $\mathrm{Cr}$-rich endiopside as disturbed cumulates and was more fractionated than the C3-basalts magma batch.

5) Eruption of basalts derived from C4 magmas by the fractional crystallization of $10.5 \%$ plagioclase, $3.5 \%$ olivine, and $2.3 \%$ clinopyroxene. The magma chamber must have been distinct from the storage chamber for $\mathrm{C} 5, \mathrm{C} 3$, and $\mathrm{C} 2$ magmas.

\section{PART 2: THE “ARC SITES”}

\section{The Palau-Kyushu Ridge}

The Palau-Kyushu Ridge (PKR) extends over 2000 $\mathrm{km}$, separating the West Philippine Basin from the Parece Vela Basin. The ridge rises up to 2000 meters above the floor of the West Philippine Basin. Rocks dredged from a steep west face in the Site 448 area (including sub-alkalic basalts and basaltic andesites with island-arc-tholeiite affinities) are extremely vesicular and suggest eruption at shallow marine depths or even sub-aerially (International Working Group on the IGCP Project "'Ophiolites," 1977).

Site 448 is located on the west edge of the ridge $\left(16^{\circ} 20.48^{\prime} \mathrm{N}, 143^{\circ} 52.45^{\prime} \mathrm{E}\right)$ in 3483 meters of water (Fig. 1). Two holes were drilled at the same location. The first hole successfully penetrated 584.5 meters before drilling problems necessitated that the hole be abandoned. A second hole was washed down for 527 meters and was then continually cored to a final depth of 914 meters. Core recovery from both holes averaged $50 \%$. Hole $448 \mathrm{~A}$ is tied stratigraphically to Hole 448 by lithologic and paleontologic horizons, but with a vertical displacement of 19 meters.

\section{Lithology and Petrography}

The combined lithostratigraphic column can be divided into 319.5 meters of middle-Miocene to middleOligocene oozes, chalk, and tuffs ( 5 units) underlain by 624 meters of volcanic "basement" (46 units). The volcanic "basement" is markedly different from typical ocean (Layer 2) crust (e.g., Hole 447A) and is characterized by igneous units (flows, sills, and dikes) interbedded with volcaniclastic breccias. A systematic account of the lithology and petrography is given in the site report, but the more important features are summarized in the following section (see Table 19).

The upper part of the "basement" section consists of relatively thick ( 20 to $50 \mathrm{~m}$ ) volcanic units (Units $6,8,9$, 11,13 , and 14), each of which consist of up to 7 individual flows. Pillowed basalts are common. Interbedded volcaniclastic breccias vary from 15 to 30 meters thick. The lower half of the "basement" section consists of more numerous volcanic units (Units 16-51) that are considerably thinner $(0.5-3 \mathrm{~m})$ and are often single flows. Pillow basalts are absent. In addition, in the deepest part of the section (below $700 \mathrm{~m}$ ), as many as 10 dikes and sills were recognized.

Nearly all the igneous units are sparsely plagioclase phyric, but sharp distinctions can be made on the basis of mafic phenocryst assemblages among plagioclaseolivine, plagioclase-clinopyroxene-orthopyroxene, and plagioclase-clinopyroxene basalts. These three petrographic types, although sometimes distinguished by trace amounts of a particular phenocryst phase, are confined to well-defined stratigraphic horizons (Table 19).

1) Olivine-bearing basalts, with few exceptions, are restricted to the uppermost units (Units 6, 8, and 11), which span 150 meters of the "basement" section. These basalts contain up to $2 \%$ of plagioclase phenocrysts $\left(\mathrm{An}_{60-70}\right)$, subordinate olivine phenocrysts (as smectite pseudomorphs), and rare phenocrysts of clinopyroxene. These flows are typically highly vesicular and oxidized.

2) Orthopyroxene (bronzite)-bearing basalts are, with one exception, restricted to Units 13 and 14. These units are relatively porphyritic and contain up to $15 \%$ plagioclase phenocrysts with minor clinopyroxene, bronzitic orthopyroxene, and rare olivine. These two units are not separated by volcaniclastic breccias and represent successive eruptions of at least 7 separate flows with a total thickness of about 50 meters.

3) Basalts containing plagioclase (up to $20 \%$ ) and minor clinopyroxene dominate the remainder of the volcanic units in Holes 448 and 448A (approximately $50 \%$ of the total volcanic basement penetrated). These thinner and often single flows are separated by relatively thick volcaniclastic breccia units. A few units from the lower part of the section are not of the plagioclaseclinopyroxene-phyric type: Unit 22 is olivine-phyric $(5 \%)$, with minor plagioclase and clinopyroxene; Unit 28 contains minor olivine in addition to plagioclase $(10 \%)$ and minor clinopyroxene; Unit 49 is extremely porphyritic, still containing $30 \%$ plagioclase, $5 \%$ clinopyroxene, and $4 \%$ orthopyroxene. The remaining sills 
Table 19. Igneous lithology of Holes 448 and 448A.

\begin{tabular}{|c|c|c|c|c|c|c|c|c|c|c|c|}
\hline \multirow[b]{2}{*}{ Hole } & \multirow[b]{2}{*}{ Unit } & \multirow[b]{2}{*}{ Type $^{a}$} & \multirow[b]{2}{*}{$D^{\mathrm{b}}$} & \multirow[b]{2}{*}{$T^{\mathrm{c}}$} & \multirow[b]{2}{*}{$N^{\mathrm{d}}$} & \multicolumn{3}{|c|}{ Phenocrysts $\mathrm{e}$} & \multirow[b]{2}{*}{ Opx } & \multirow[b]{2}{*}{ Texture } & \multirow[b]{2}{*}{ Comments } \\
\hline & & & & & & Ol & $\mathrm{Pl}$ & $\mathrm{Cpx}$ & & & \\
\hline \multirow[t]{5}{*}{448} & L6 & $\mathrm{P}$ & 319.5 & 38.5 & 1 & tr & 1 & - & - & Hyalopilitic to subophitic & Highly vesicular, oxidized \\
\hline & L8 & $\mathrm{P} / \mathrm{F}$ & 376.5 & 27.5 & $6 ?$ & $<2$ & 2 & $\operatorname{tr}$ & - & Pilotaxitic to ophitic & Highly vesicular, oxidized \\
\hline & L9 & $\mathrm{P} / \mathrm{F}$ & 404.0 & 23.0 & 1 & - & - & - & - & Hyalopilitic to subophitic & Moderately vesicular \\
\hline & L11 & $\mathrm{F}$ & 456.0 & 33.5 & 5 & $\operatorname{tr}$ & $<1$ & - & - & Hyalopilitic & Moderately vesicular \\
\hline & L13 & $\mathrm{F}$ & 521.0 & 35.5 & $8 ?$ & $\operatorname{tr}$ & $10-15$ & 2 & $<1$ & Hyalopilitic & \\
\hline \multirow[t]{21}{*}{$448 \mathrm{~A}$} & $\begin{array}{l}\text { L13 } \\
\text { L14 }\end{array}$ & $\begin{array}{l}\mathrm{P} \\
\mathrm{P}\end{array}$ & $\begin{array}{l}537.5 \\
575.0\end{array}$ & 38.0 & $2 ?$ & $\operatorname{tr}$ & $7-15$ & 2 & $<1$ & Intersertal & Extremely vesicular \\
\hline & L16 & $\mathrm{F}$ & 613.5 & 1.5 & 1 & - & 1 & 1 & - & Intersertal & Highly vesicular \\
\hline & L18 & $\mathrm{F}$ & 623.0 & 9.0 & 1 & - & tr & 1 & - & Intersertal & Highly vesicular \\
\hline & L20 & F & 660.5 & 9.5 & 1 & - & $\operatorname{tr}$ & - & - & Intersertal & No vesicles, very altered, native $\mathrm{Cu}$. \\
\hline & L22 & $\mathrm{F}$ & 694.0 & 5.5 & 1 & 5 & 3 & 1 & - & Intersertal & \\
\hline & L23 & B & 699.5 & 15.0 & $1 ?$ & & \multicolumn{2}{|c|}{ no data } & & - & Autobreccia? \\
\hline & L24 & $\mathrm{F}$ & 714.5 & 3.5 & 1 & - & 10 & 2 & - & Intersertal & \\
\hline & L26 & $\mathrm{D} / \mathrm{S}$ & 727.0 & 1.0 & 1 & - & 5 & - & - & Hyalopilitic & Relatively fresh \\
\hline & L27 & $\mathrm{D}$ & 728.0 & 3.5 & 1 & - & - & - & - & Vitryophyric & Similar to L26 \\
\hline & L28 & D & 731.5 & 5.0 & 1 & 1 & 10 & 1 & - & Intersertal & Slightly vesicular \\
\hline & L31 & F/B & 757.0 & 11.5 & 2 & - & 5 & 1 & - & Subophitic & Flows and flow breccias \\
\hline & L33 & $\mathrm{F}$ ? & 769.5 & 14.0 & 1 & - & $1-20$ & 1 & - & Intersertal & Slightly vesicular \\
\hline & L35 & S? & 792.5 & 2.0 & 1 & - & 10 & 2 & - & Hyalopilitic & No vesicles \\
\hline & L37 & D & 802.0 & 4.0 & 1 & - & 6 & 1 & - & Intersertal & Fresh \\
\hline & L39 & $\mathrm{F}$ & 810.5 & 3.0 & $2 ?$ & - & 10 & 1 & - & Intersertal & Two flows with interflow breccia \\
\hline & L41 & F & 832.0 & 11.5 & 1 & - & 15 & 1 & - & Intersertal & No vesicles \\
\hline & L43 & $\mathrm{F}$ & 843.0 & 5.0 & 1 & - & $\operatorname{tr}$ & $\operatorname{tr}$ & - & Intersertal & Slightly vesicular \\
\hline & L45 & S & 858.5 & 6.0 & 1 & - & 10 & 1 & - & Intersertal & Slightly vesicular \\
\hline & L47 & $\mathrm{S}$ & 866.5 & 1.0 & 1 & & \multicolumn{2}{|c|}{ no data } & & - & Slightly vesicular \\
\hline & L49 & S & 887.0 & 9.0 & 1 & - & 30 & 5 & 4 & Subophitic & Very porphyritic \\
\hline & L51 & D & 902.0 & 12.0 & 1 & & \multicolumn{2}{|c|}{ no data } & & - & Pyrite-rich \\
\hline
\end{tabular}

${ }^{a} \mathrm{P}=$ pillow lava $\mathrm{F}=$ massive flow; $\mathrm{B}=$ flow breccia; $\mathrm{D}=$ dike; and $\mathrm{S}=$ sill.

b $D=$ sub-bottom depth (m) to top of unit.

c $T=$ unit thickness $(\mathrm{m})$.

d $N=$ number of cooling units.

e Estimated modal abundances (\%).

and dikes are all plagioclase-clinopyroxene-phyric basalts.

Thus, with a few exceptions, the three major petrographic types occur down-hole in this sequence: plagioclase-olivine basalts, plagioclase-clinopyroxene orthopyroxene basalts, and plagioclase-clinopyroxene basalts. The relative importance of each petrographic type is misleading in terms of the numbers of "units." The cumulative thicknesses of the three types are, in fact, broadly similar (Table 20), considering the widely different depth ranges that they span.

\section{Alteration}

The basalts and the volcaniclastic rocks from Holes 448 and $448 \mathrm{~A}$ are extensively altered. Throughout the entire section, pyrogenic phases are replaced by clays, zeolites, carbonates, and sulphides. Fresh olivine is found only rarely in unaltered glassy margins (Scott, this volume); elsewhere it is completely replaced by smectites and opaque oxides. Plagioclase is usually replaced by clays, except in fresh glassy margins. Clinopyroxene, however, is relatively fresh, except in the most intensely altered areas of the section.

Two zones of alteration are recognized. The uppermost 150 meters of vesicular basalts and breccias (Units 6 to 10 ) are yellow or yellowish brown in color, suggesting oxidative and probably low-temperature alteration. Below 150 meters (approximately 500 meters sub-
Table 20. Cumulative thickness of the three major petrographic types in Holes 448 and 448A.

\begin{tabular}{lrrrc}
$\begin{array}{l}\text { Petrographic } \\
\text { Group }\end{array}$ & $T^{\mathrm{a}}$ & $N_{\mathrm{L}}{ }^{\mathrm{b}}$ & $N_{\mathrm{c}}{ }^{\mathrm{c}}$ & Depth Interval (m) \\
\hline Ol-basalts & 104.5 & 3 & 12 & $337-427$ \\
Opx-basalts & 73.5 & 3 & 7 & $511-575$ \\
Cpx-basalts & 132.5 & 20 & 22 & $613-914$ \\
\hline
\end{tabular}

$\mathrm{a}_{T}=$ cumulate thickness $(\mathrm{m})$.

$\mathrm{b}_{N_{\mathrm{L}}}=$ number of lithologic units.

$\mathrm{c}_{N_{\mathrm{c}}}=$ number of cooling units.

bottom), beginning in breccia Unit 11, the yellow oxidized matrices give way to greenish gray or greenish blue matrices. Disseminations and veins of native copper along with copper and iron sulphides point to hydrothermal activity under more reducing conditions than those in the upper zone. Aldrich et al. (this volume) recognize a hydrothermal metamorphic gradient in Holes 448 and 448A, which suggests a geothermal gradient characteristic of an island-arc environment.

\section{The West Mariana Ridge}

The West Mariana Ridge (WMR) separates the Parece Vela Basin from the young and currently spreading Mariana Trough. Karig (1975) interpreted this north-south trending ridge as a remnant island arc 
that was left behind when the active volcanic Mariana arc broke away during spreading of the Mariana Trough. The ridge itself is somewhat shallower than the PKR, usually less than 2000 meters below sea level, but rising in parts to only 55 meters below sea level. Vesicular dacites were dredged from the deeper sections of the ridge (3000-4000 meters); to account for their present depth, Karig and Glassley (1970) suggest that subsidence of the ridge must have begun in the Quaternary.

Site 451 is located on the eastern edge of the West Mariana Ridge $\left(18^{\circ} 00.88^{\prime} \mathrm{N}, 143^{\circ} 16.57^{\prime} \mathrm{E}\right)$ in 2600 meters of water (Fig. 1). Hole 451 successfully penetrated 930.5 meters of massive coarse volcaniclastic sediments before scheduling considerations terminated drilling operations.

\section{Lithology and Petrography}

No igneous units (i.e., lava flows, sills, or dikes) were penetrated in Hole 451. With the exception of the last 4 meters (see the forthcoming material), sediments and volcaniclastic rocks only were recovered. These are divided into three major units, which range from late Quaternary to late Miocene (see the site report for details). Units 1 and 2 consist of foraminifer or nannofossil oozes and carbonate-rich vitric ash, respectively. Unit 3 consists of 861 meters of repetitious, coarse, angular, volcanic breccias that grade into bioturbated vitric tuffs. The least-altered volcanic clasts from this unit were sampled for petrographic study and chemical analysis. These consist predominantly of basalts and rare andesites, divided into five petrographic groups by the shipboard scientists:

1) plagioclase-clinopyroxene-orthopyroxene-magnetite-olivine andesites,

2) plagioclase-clinopyroxene-magnetite-olivine andesites,

3) plagioclase-clinopyroxene basalt,

4) clinopyroxene-plagioclase basalt, and

5) aphyric basalt.

Andesite clasts contain abundant phenocrysts of strongly zoned plagioclase (up to $30 \%, \mathrm{An}_{50-60}$ ), with subordinate clinopyroxene (up to $10 \%$ ) and magnetite (up to $5 \%$ ). Rare olivine or orthopyroxene phenocrysts are present in some samples, usually replaced by green and brown smectites. The groundmasses are notably poor in mafic minerals. The basaltic clasts contain variable quantities of more-calcic plagioclase phenocrysts (aphyric to 40\%) and clinopyroxene (0-20\%), with rare phenocrysts of olivine (replaced by smectite).

In the last 4 meters of drilling, a resistant basaltic unit was penetrated. There is no clear evidence to determine whether the small quantity of basalt recovered from the bottom of the hole represents a large clast or an igneous unit, such as a lava flow or a sill. The basalt is extremely altered to green clays and contains numerous small pockets of native copper. Circumstantial evidence (see the site report) suggests that the basalt may represent an igneous unit marking the beginning of a sequence of interbedded flows and breccias similar to the basement of Holes 448 and 448A.

\section{Geochemical Results}

Fifty-three analyses of igneous units and of leastaltered clasts from the interbedded breccias from the Palau-Kyushu Ridge (Holes 448 and 448A) are presented in Tables 21 and 22 . In general terms, the basalts and basaltic andesites from the PKR are quartz-normative tholeiites containing $48 \%$ to $56 \% \mathrm{SiO}_{2}, 13 \%$ to $17 \% \mathrm{Al}_{2} \mathrm{O}_{3}, 7.5 \%$ to $10.0 \% \mathrm{CaO}$, and $10 \%$ to $15 \%$ iron as total $\mathrm{FeO}$. When plotted on the AFM diagram (Fig. 23 ), the PKR basalts are thus significantly more ironrich than most MORB (including the basalts from the West Philippine Basin and Parece Vela Basin) and have $\mathrm{FeO} / \mathrm{MgO}$ ratios ranging from 1.5 to 4.0 . The "fractionated" character of these basalts is emphasized by a relatively high content of $\mathrm{TiO}_{2}(1.0-1.8 \%)$ and by extremely low abundances of $\mathrm{Ni}(0-20 \mathrm{ppm})$ and $\mathrm{Cr}(20-50$ ppm). Abundances of the low-field-strength (LFS) trace elements (i.e., with a radius/charge ratio over 2.0 [Saunders et al., in press])-Th (1-2 ppm), $\mathrm{Pb}(4 \mathrm{ppm})$, $\mathrm{Ba}(30-80 \mathrm{ppm}), \mathrm{Sr}(150-200 \mathrm{ppm})$, and $\mathrm{Rb}$ - are slightly greater than, for example, in MORB. However, abundances of the REE and a number of high-fieldstrength (HFS) elements (Saunders et al., in press) such as $\mathrm{Zr}$ and $\mathrm{Nb}$-are remarkably low for basalts with fractionated major elements and low $\mathrm{Cr}$ and $\mathrm{Ni}$ contents. Concentrations of $\mathrm{La} \mathrm{(3-8} \mathrm{ppm),} \mathrm{Ce}$ (5-15 ppm), $\mathrm{Zr}(35-80 \mathrm{ppm})$, and $\mathrm{Nb}$ (less than $1 \mathrm{ppm}$ ) are more typical of primitive $\mathrm{Mg}$-Ca-rich MORB than these apparently fractionated iron-rich tholeiites. These basalts are essentially identical to basalts that form the IslandArc Tholeiite Series (IATS) of Jakeš and Gill (1970) (see Table 23).

Nine analyses of the least-altered clasts from the tuffs and breccias from Hole 451 on the West Mariana Ridge (WMR) are presented in Table 24 . The clasts from the WMR are geochemically different from the basaltic island-arc tholeiites from the PKR, despite a wide range of compositional variation on each side. These differences are illustrated in various plots of major elements versus $\mathrm{FeO} / \mathrm{MgO}$ ratio (Figs. 24-30) and in plots of selected minor and trace elements versus $\mathrm{Zr}$ (Fig. 31-38).

The basalt and andesite clasts from the WMR are characterized by low $\mathrm{FeO} / \mathrm{MgO}$ ratios (1.0-2.0), with a wide range of $\mathrm{SiO}_{2}$ contents (48-58\%) (Fig. 24). At equivalent $\mathrm{FeO} / \mathrm{MgO}$ ratios, it is clear from Figures 25 to 29 that the WMR rocks are poorer in both $\mathrm{FeO}$ and $\mathrm{MgO}$ and richer in $\mathrm{Al}_{2} \mathrm{O}_{3}(18-20 \%)$ and $\mathrm{CaO}(9-13 \%)$. The WMR rocks, similar to those from the PKR, have very low abundances of $\mathrm{Ni}$ (usually less than $25 \mathrm{ppm}$ ) and $\mathrm{Cr}$ (usually less than $50 \mathrm{ppm}$ ) (Figs. 31 and 32), coupled with low abundances of HFS ions such as $\mathrm{Zr}$ (30-80 ppm), $\mathrm{Nb}$ (less than $1 \mathrm{ppm})$, and Y (12-15 ppm) (e.g., Fig. 34). The most important geochemical feature of the WMR basalts and andesites is the relatively high abundances of low field strength (LFS) ions such as Th, $\mathrm{Pb}, \mathrm{Ba}, \mathrm{Sr}$, and $\mathrm{Rb}$ and enrichment of light rare-earth elements such as $\mathrm{La}$ or $\mathrm{Ce}$ relative to high field strength (HFS) ions such as $\mathrm{Y}$ or $\mathrm{Zr}$. For example, $\mathrm{Ba}$ and $\mathrm{Sr}$ contents of the PKR arc tholeiites are slightly higher 
Table 21. Analyses of basalts from Hole 448 .

\begin{tabular}{|c|c|c|c|c|c|c|c|c|c|c|c|c|c|c|c|c|c|c|c|c|}
\hline Core & 37 & 39 & 39 & 40 & 43 & 44 & 46 & 48 & 48 & 48 & 48 & 51 & 52 & 53 & 57 & 58 & 58 & 59 & 59 & 61 \\
\hline Section & 1 & 1 & 2 & 1 & 1 & 1 & 1 & 1 & 2 & 2 & 3 & 4 & 1 & 2 & 2 & 3 & 4 & 2 & 3 & 3 \\
\hline Interval & 32 & 116 & 32 & 82 & 119 & 103 & 135 & 77 & 43 & 93 & 22 & 38 & 80 & 59 & 120 & 77 & 138 & 61 & 74 & 55 \\
\hline $\mathrm{SiO}_{2}$ & 29.2 & 49.4 & 49.3 & 49.8 & 48.5 & 49.6 & 49.1 & 47.9 & 49.1 & 47.7 & 49.8 & 49.4 & 49.2 & 49.2 & 48.9 & 49.9 & 48.0 & 50.7 & 50.0 & 50.2 \\
\hline $\mathrm{TiO}_{2}$ & 1.54 & 1.64 & 1.63 & 1.52 & 1.60 & 1.54 & 1.57 & 1.60 & 1.58 & 1.55 & 1.52 & 1.28 & 1.21 & 1.15 & 0.81 & 1.12 & 1.02 & 1.09 & 1.10 & 1.12 \\
\hline $\mathrm{Al}_{2} \mathrm{O}_{3}$ & 14.2 & 13.8 & 14.0 & 12.7 & 13.4 & 14.0 & 13.2 & 14.6 & 13.9 & 14.1 & 14.3 & 13.4 & 13.9 & 14.7 & 17.1 & 14.5 & 14.2 & 16.8 & 16.4 & 15.0 \\
\hline $\mathrm{tFe}_{2} \mathrm{O}_{3}$ & 14.73 & 15.09 & 15.26 & 15.02 & 16.14 & 15.56 & 16.58 & 16.23 & 16.52 & 15.84 & 15.48 & 15.98 & 14.07 & 13.46 & 11.63 & 12.52 & 11.38 & 12.01 & 11.64 & 12.24 \\
\hline $\mathrm{MnO}$ & 0.22 & 0.22 & 0.22 & 0.24 & 0.28 & 0.23 & 0.28 & 0.23 & 0.28 & 0.25 & 0.23 & 0.22 & 0.24 & 0.20 & 0.22 & 0.19 & 0.17 & 0.19 & 0.17 & 0.15 \\
\hline $\mathrm{MgO}$ & $\begin{array}{l}4.67 \\
\end{array}$ & 4.64 & 4.14 & 4.67 & 3.59 & 4.63 & 2.98 & 3.24 & 3.02 & 3.73 & 4.48 & 5.11 & 4.56 & 5.19 & 5.37 & 4.52 & 3.88 & 4.47 & 4.28 & 6.30 \\
\hline $\mathrm{CaO}$ & 10.27 & 9.96 & 9.60 & 8.82 & 8.63 & 9.54 & 8.21 & 9.45 & 8.08 & 10.29 & 9.53 & 9.29 & 9.69 & 10.23 & 10.56 & 9.24 & 12.74 & 9.80 & 10.27 & 8.84 \\
\hline $\mathrm{Na}_{2} \mathrm{O}$ & 2.93 & 2.90 & 3.17 & 2.72 & 2.81 & 2.95 & 2.76 & 3.11 & 2.79 & 3.00 & 2.85 & 2.40 & 2.80 & 3.33 & 2.45 & 3.39 & 4.56 & 2.98 & 3.58 & 3.44 \\
\hline $\mathrm{K}_{2} \mathrm{O}$ & 0.72 & 0.79 & 0.80 & 1.61 & 1.31 & 0.57 & 1.51 & 0.86 & 0.96 & 0.61 & 0.68 & 1.10 & 1.14 & 0.47 & 0.56 & 1.65 & 1.20 & 0.83 & 1.19 & 1.41 \\
\hline $\mathrm{P}_{2} \mathrm{O}_{5}$ & 0.24 & 0.25 & 0.23 & 0.14 & 0.21 & 0.19 & 0.10 & 0.26 & 0.21 & 0.76 & 0.29 & 0.07 & 0.14 & 0.12 & 0.03 & 0.08 & 0.20 & 0.09 & 0.12 & 0.13 \\
\hline Total & 98.65 & 98.62 & 98.31 & 97.23 & 96.48 & 98.80 & 96.35 & 97.49 & 96.38 & 97.44 & 99.16 & 98.30 & 96.94 & 98.04 & 97.55 & 97.10 & 97.31 & 98.96 & 98.75 & 98.79 \\
\hline
\end{tabular}

$\begin{array}{lrr}\text { Trace } & \text { Elements } & \text { (ppm) } \\ \mathrm{Ni} & 12 & 11 \\ \mathrm{Cr} & 32 & 29 \\ \mathrm{Zn} & 113 & 123 \\ \mathrm{Ga} & 20 & 18 \\ \mathrm{Rb} & 8 & 6 \\ \mathrm{Sr} & 157 & 153 \\ \mathrm{Y} & 30 & 40 \\ \mathrm{Zr} & 46 & 42 \\ \mathrm{Nb} & 1 & <1 \\ \mathrm{Ba} & 27 & 37 \\ \mathrm{La} & 6 & 6 \\ \mathrm{Ce} & 14 & 10 \\ \mathrm{Nd} & 9 & 9 \\ \mathrm{~Pb} & 3 & 4 \\ \mathrm{Th} & 2 & <1\end{array}$

$\begin{array}{rr}10 & 12 \\ 27 & 25 \\ 110 & 110 \\ 20 & 17 \\ 11 & 20 \\ 154 & 143 \\ 30 & 45 \\ 27 & 43 \\ 1 & <1 \\ 68 & 64 \\ 5 & 7 \\ 11 & 9 \\ 9 & 12 \\ 2 & 4 \\ <1 & 1\end{array}$

$\begin{array}{rr}8 & 2 \\ 11 & 13 \\ 128 & 117 \\ 22 & 19 \\ 15 & 5 \\ 171 & 160 \\ 56 & 29 \\ 52 & 47 \\ 1 & <1 \\ 78 & 37 \\ 8 & 6 \\ 13 & 10 \\ 11 & 9 \\ 4 & 4 \\ 3 & <1\end{array}$

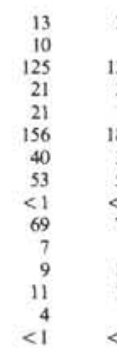

$\begin{array}{rrr}21 & 14 & 15 \\ 12 & 10 & 23 \\ 124 & 123 & 124 \\ 24 & 21 & 24 \\ 10 & 13 & 8 \\ 180 & 174 & 192 \\ 36 & 32 & 40 \\ 57 & 56 & 48 \\ <1 & <1 & <1 \\ 78 & 68 & 55 \\ 6 & 5 & 7 \\ 13 & 8 & 11 \\ 11 & 9 & 9 \\ 2 & 4 & 6 \\ <1 & <1 & <1\end{array}$

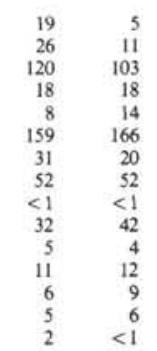

30
12
99
19
13
187
26
65
$<1$
50
6
12
10
6
$<1$

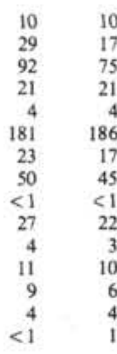

14
25
92
19
15
167
29
68
$<1$
40
4
16
10
4
$<1$

$\begin{array}{rrrr}9 & 19 & 16 & 17 \\ 18 & 25 & 28 & 25 \\ 82 & 81 & 91 & 83 \\ 19 & 15 & 19 & 19 \\ 12 & <1 & 8 & 13 \\ 175 & 170 & 177 & 172 \\ 29 & 25 & 27 & 29 \\ 68 & 70 & 72 & 74 \\ <1 & <1 & <1 & <1 \\ 48 & 39 & 57 & 63 \\ 5 & 6 & 5 & 6 \\ 13 & 10 & 11 & 11 \\ 10 & 10 & 9 & 9 \\ 5 & 3 & 3 & 5 \\ <1 & <1 & 1 & 2\end{array}$

\begin{tabular}{|c|c|c|c|c|c|c|c|c|c|c|c|c|c|c|c|c|c|c|c|c|}
\hline Q & 0.0 & 0.0 & 0.0 & 0.0 & 0.0 & 0.0 & 0.8 & 0.0 & 2.3 & 0.0 & 0.3 & 0.0 & 0.0 & 0.0 & 0.0 & 0.0 & 0.0 & 0.0 & 0.0 & 0.0 \\
\hline Or & 4.3 & 4.7 & 4.8 & 9.8 & 8.0 & 3.4 & 9.3 & 5.2 & 5.9 & 3.7 & 4.0 & 6.6 & 6.9 & 2.8 & 3.4 & 10.0 & 7.3 & 5.0 & 7.1 & 8.4 \\
\hline$A b$ & 25.1 & 24.9 & 27.3 & 23.7 & 24.6 & 25.3 & 24.2 & 27.0 & 24.5 & 26.1 & 24.3 & 20.7 & 24.4 & 28.7 & 21.3 & 29.5 & 15.3 & 25.5 & 28.8 & 29.5 \\
\hline An & 23.7 & 22.5 & 21.9 & 18.3 & 20.8 & 23.5 & 20.0 & 24.0 & 23.3 & 23.7 & 24.5 & 23.0 & 22.7 & 24.2 & 34.8 & 20.0 & 15.0 & 30.4 & 25.6 & 21.6 \\
\hline $\mathrm{Ne}$ & 0.0 & 0.0 & 0.0 & 0.0 & 0.0 & 0.0 & 0.0 & 0.0 & 0.0 & 0.0 & 0.0 & 0.0 & 0.0 & 0.0 & 0.0 & 0.0 & 13.2 & 0.0 & 1.0 & 0.0 \\
\hline Di & 22.2 & 21.8 & 21.1 & 21.7 & 18.9 & 19.5 & 18.6 & 19.1 & 14.4 & 20.1 & 18.0 & 19.7 & 21.8 & 22.4 & 15.6 & 22.4 & 40.7 & 15.2 & 21.2 & 18.2 \\
\hline $\mathrm{Hy}$ & 12.9 & 15.9 & 12.9 & 17.4 & 18.1 & 19.9 & 19.4 & 9.9 & 21.5 & 14.7 & 21.2 & 22.5 & 14.0 & 6.2 & 17.7 & 0.8 & 0.0 & 18.1 & 0.0 & 1.5 \\
\hline OI & 4.3 & 2.5 & 4.2 & 1.8 & 1.5 & 0.9 & 0.0 & 6.7 & 0.0 & 2.6 & 0.0 & 0.6 & 3.6 & 9.5 & 2.6 & 11.5 & 2.9 & 0.4 & 10.9 & 15.2 \\
\hline Mt & 2.6 & 2.7 & 2.7 & 2.7 & 2.9 & 2.7 & 3.0 & 2.9 & 3.0 & 2.8 & 2.7 & 2.8 & 2.5 & 2.4 & 2.1 & 2.2 & 2.0 & 2.1 & 2.1 & 2.2 \\
\hline IIm & 3.0 & 3.2 & 3.1 & 3.0 & 3.1 & 3.0 & 3.1 & 3.1 & 3.1 & 3.0 & 2.9 & 2.5 & 2.4 & 2.2 & 1.6 & 2.2 & 2.0 & 2.1 & 2.1 & 2.2 \\
\hline$A p$ & 0.6 & 0.6 & 0.6 & 0.3 & 0.5 & 0.5 & 0.2 & 0.6 & 0.5 & 1.8 & 0.7 & 0.2 & 0.4 & 0.3 & 0.1 & 0.2 & 0.5 & 0.2 & 0.3 & 0.3 \\
\hline Unit & L6 & L6 & L6 & L6 & L8 & L8 & L8 & L8 & L8 & L8 & L8 & L10 & L10 & L10 & L12 & L12 & L12 & L12 & L12 & L12 \\
\hline
\end{tabular}

than typical MORB, ranging from $30-80 \mathrm{ppm}$ and $150-200 \mathrm{ppm}$, respectively. Substantially higher abundances of these elements characterize the WMR rocks that contain 110 to $450 \mathrm{ppm} \mathrm{Ba}$ and 450 to $600 \mathrm{ppm} \mathrm{Sr}$ (Figs. 37 and 38). Plots of $\mathrm{Ce}$ and $\mathrm{La}$ versus $\mathrm{Zr}$ (Figs. 35 and 36) show the WMR basalts and andesites to have higher $\mathrm{La} / \mathrm{Zr}$ and $\mathrm{Ce} / \mathrm{Zr}$ ratios than the PKR arc tholeiites. A plot of Ce versus Y (normalized to chondrites [Nakamura, 1974]) suggests that the WMR rocks would have light REE-enriched REE patterns with $\mathrm{Ce}_{\mathrm{N}} / \mathrm{Y}_{\mathrm{N}}$ ratios $\sim 2$, in contrast to the flat or slightly light REE-depleted REE patterns that characterize the PKR arc tholeiites (Fig. 39).

The basalt and andesite clasts that constitute the volcanic breccias from the WMR are clearly different in composition from the typical island-arc tholeiites drilled on the Palau-Kyushu Ridge. The $\mathrm{SiO}_{2}$-rich, iron-poor fractionation trend, coupled with relatively high concentrations of $\mathrm{CaO}, \mathrm{Al}_{2} \mathrm{O}_{3}, \mathrm{Th}, \mathrm{Pb}, \mathrm{Ba}, \mathrm{Sr}$, and $\mathrm{Rb}$ and a light REE-enriched REE pattern, strongly suggests that the rocks drilled on the WMR have affinities with the calc-alkalic magma series (see Table 23).

\section{Chemical Variation within Holes 448 and 448A Arc Tholeiites}

The 46 igneous units penetrated on the Palau-Kyushu Ridge have been divided into three major petrographic groups according to the occurrence of olivine or orthopyroxene as a phenocryst phase. Basalts containing olivine (but not orthopyroxene) phenocrysts are restricted to the youngest pillow lavas and flows forming Units L6, L8, and L11 and an isolated, relatively olivine-phyric flow (Unit L22) deeper in the section. Orthopyroxene phenocrysts are found in the relatively plagioclase-phyric (with clinopyroxene and rare olivine) basalts that form Units L13 and L14. The remaining igneous units below these distinctive four-phase basalts contain only clinopyroxene as a mafic phenocryst phase. For convenience, basalts belonging to these three major petrographic groups will be referred to as olbasalts, $o p x$-basalts, and $c p x$-basalts, respectively.

Many inter-element plots reveal that the petrographic groups are chemically distinct, particularly in terms of degree of iron enrichment and in ratios of "lesscompatible" to "more-compatible" elements, such as $\mathrm{Ti} / \mathrm{Zr}, \mathrm{Y} / \mathrm{Zr}$, or $\mathrm{Ce} / \mathrm{Y}$. On the $\mathrm{Ti} / \mathrm{Zr}$ diagram (Fig. 33), the arc tholeiites from Holes 448 and $448 \mathrm{~A}$ are widely scattered with $\mathrm{Ti} / \mathrm{Zr}$ ratios ranging from less than 100 to over 200. This is in marked contrast to most MORB, which usually has a narrow range of $\mathrm{Ti} / \mathrm{Zr}$ ratios around 110 (e.g., Sun et al., 1979). The youngest basalts from the PKR, the ol-basalts, fall into two groups. Units 6 and 8 have the highest $\mathrm{Ti} / \mathrm{Zr}$ ratios of all the PKR arc tholeiites (ranging from 200 to 220 ). $\mathrm{Ol}$-basalts from Unit 11 have significantly lower $\mathrm{Ti} / \mathrm{Zr}$ ratios of $\sim 125$. The relatively olivine-phyric ol-basalt from Unit $\mathrm{L} 22$ has a $\mathrm{Ti} / \mathrm{Zr}$ ratio similar to the $\mathrm{L} 11$ ol-basalts. The distinctive four-phase $o p x$-basalts are characterized by 
low $\mathrm{Ti} / \mathrm{Zr}$ ratios $(\sim 100)$ and form a relatively tight group. The $c p x$-basalts, which dominate the remaining igneous units found in the lower half of Holes 448 and $448 \mathrm{~A}$, have a relatively wide range of $\mathrm{Ti} / \mathrm{Zr}$ ratios (from 120 to 200 ). Adjacent units with similar $\mathrm{Ti} / \mathrm{Zr}$ ratios are rare. Other plots of elements such as $\mathrm{Y} / \mathrm{Zr}, \mathrm{La} / \mathrm{Zr}$, $\mathrm{Ce} / \mathrm{Zr}$, or $\mathrm{Ce}_{\mathrm{N}} / \mathrm{Y}_{\mathrm{N}}$ (Figs. 34-36 and 39) show similar relationships between the petrographic groups but with poorer resolution than is shown in the $\mathrm{Ti}$ versus $\mathrm{Zr}$ diagram. The $o p x$-basalts, geochemically "more distinct" than either the $o l$-basalts or the $c p x$-basalts, are more enriched in $\mathrm{Zr}$, with a similar range of $\mathrm{Y}, \mathrm{Ce}$, or La contents. On the $\mathrm{Ce}_{\mathrm{N}} / \mathrm{Y}_{\mathrm{N}}$ diagram (Fig. 39), the majority of PKR arc tholeiites have chondritic to moderately depleted REE patterns, however, the opxbasalts are slightly more light REE enriched than the olor $c p x$-basalts.

Geochemical differences between the petrographic groups are not only restricted to the incompatible trace elements. In terms of iron-enrichment, the $c p x$-basalts are least evolved, with low $\mathrm{FeO} / \mathrm{MgO}$ ratios ranging from 1.3 to 2.5 . The $o p x$-basalts are slightly more evolved $(\mathrm{FeO} / \mathrm{MgO}$ ranges from $1.8-2.6)$ but with lower contents of $\mathrm{FeO}$ and $\mathrm{MgO}$ ratios (Figs. 27 and 28). The $o l$-basalts display a wide range of $\mathrm{FeO} / \mathrm{MgO}$ ratios, but the majority of analyses are considerably more iron-rich than either the opx-or $c p x$-basalts. The ol-basalt from the isolated Unit L22 is one of the least-differentiated arc tholeiites from the Palau-Kyushu Ridge, with an $\mathrm{FeO} / \mathrm{MgO}$ ratio of 1.4 and relatively high levels of $\mathrm{Cr}$ and $\mathrm{Ni}(309$ and $111 \mathrm{ppm}$, respectively. The ol-basalts from Unit L11 are somewhat evolved, with $\mathrm{FeO} / \mathrm{MgO}$ ratios similar to the $o p x$-basalts. The upper ol-basalts from Units L6 and L8, however, are the most evolved arc tholeiites from the $\mathrm{PKR}$, with $\mathrm{FeO} / \mathrm{MgO}$ ratios from 2.6 to 4.2 .

Plots of other major elements versus the $\mathrm{FeO} / \mathrm{MgO}$ ratio show that the distinctive $o p x$-basalts are different from both the $c p x$-basalts and the moderately evolved (e.g., L11) ol-basalts. At equivalent $\mathrm{FeO} / \mathrm{MgO}$ ratios, the opx-basalts are notably richer in $\mathrm{Al}_{2} \mathrm{O}_{3}$ and poorer not only in both $\mathrm{FeO}$ and $\mathrm{MgO}$ but also in $\mathrm{TiO}_{2}$ (Figs. $25-28$ ). The opx-basalts contain up to $15 \%$ plagioclase phenocrysts (Table 19), in contrast to the sparsely phyric $o l$ - and $c p x$-basalts. It is possible to account for the chemical differences between the opx-and the cpxor ol-basalts in terms of the higher modal abundances of plagioclase in the opx-basalts.

\section{Discussion}

\section{Genesis of Island-Arc Tholeiite Magmas}

The geochemical features of the PKR arc tholeiites and the WMR calc-alkalic basalts are summarized in Table 23. Petrographic group averages from Holes 448 and 448A and average clast composition from Hole 451 are normalized to a typical N-MORB (Sun et al., 1979) and compared in Figure 40. Although variable in composition, arc tholeiites from young arc systems are geochemically more evolved than MORB (higher $\mathrm{SiO}_{2}$ mode, high $\mathrm{FeO} / \mathrm{MgO}$ ratios, low $\mathrm{Cr}$ and $\mathrm{Ni}$ contents, etc.), but contents of HFS ions ( $\mathrm{Ti}, \mathrm{Zr}, \mathrm{Y}$, and the heavy
REE) are often more similar to primitive MORB. Nevertheless, because arc tholeiites have LFS-element abundances comparable to those of MORB (see the following material) and flat or depleted REE patterns, they are closer in composition to MORB than any other terrestrial magma type. A fairly similar source or the possibility of one magma type being derived from the other is therefore indicated.

Young oceanic island arcs such as the Palau-Kyushu Ridge, the West Mariana Ridge, or the active Mariana arc have formed in areas without continental crust, and their volcanic rocks must be derived from the subducted lithospheric crust or from the superjacent mantle wedge. The relative contribution of the subducted slab or the overlying mantle wedge remains controversial. It is generally agreed, however, that the introduction of water into the upper mantle via the subduction of hydrous mineral phases (i.e., secondary alteration minerals, amphibolites, serpentinite) plays a vital role in island-arc magmatism. In a popular model for the genesis of island-arc tholeiites, water, released by dehydration reactions in the descending slab, lowers the solidus of the overlying mantle, resulting in partial melting and magma formation (Green, 1972; Ewart et al., 1973; Ringwood, 1977). Experiments performed by Nichols and Ringwood (1973) and Nichols (1974) show that the water-saturated partial melting of pyrolite results in tholeiitic liquids close to silica saturation. They have proposed extensive fractional crystallization of olivine to explain depletion of $\mathrm{Mg}, \mathrm{Cr}$, and $\mathrm{Ni}$ and unfractionated REE patterns in arc tholeiites. The relatively high $P_{\mathrm{O}_{2}}$ expected under wet melting conditions might also inhibit the enrichment of iron during subsequent fractionation.

More recently, trace-element and isotope data for island-arc volcanics have suggested that the hydrous fluids driven off the descending slab transfer the more mobile LFS elements ( $\mathrm{Th}, \mathrm{Pb}, \mathrm{Rb}, \mathrm{Ba}$, and $\mathrm{K}$ and radiogenic $\mathrm{Sr}$ ) into the overlying mantle wedge (Best, 1975; Hawkesworth et al., 1977, Saunders et al., in press). Possible sources for these mobile LFS elements and radiogenic $\mathrm{Sr}$ are the hydrous secondary minerals found in altered ocean crust or subducted sediments. The role of subducted sediment (rich in elements such as $\mathrm{Pb}, \mathrm{Th}$, $\mathrm{Rb}, \mathrm{Ba}$, and radiogenic $\mathrm{Sr}$ ) in island-arc magma genesis remains problematic. Many authors have invoked some degree of sediment involvement during magma genesis at a number of island arcs (e.g., Armstrong, 1968; 1971; Ewart and Stipp, 1968; Tatsumoto, 1969; Armstrong and Cooper, 1971; Donnelly et al., 1971; Pushkar et al., 1973; Whitford and Jezek, 1979). At the Mariana arc, where a thick accretionary sedimentary prism is absent (Leg 60 Scientific Party, 1979), it is difficult to imagine that the 0.5 to $1 \mathrm{~km}$ of sediment on the descending Pacific plate can be anything other than subducted. Nevertheless, recent $\mathrm{Pb}, \mathrm{Sr}$, and $\mathrm{Nd}$ isotope data for the Mariana arc (Meijer, 1976; Dixon and Batiza, 1979) and from Fiji (Gill, 1974) and the Tonga-Kermadek arc (Oversby and Ewart, 1972) suggest that sediment contamination at these intra-oceanic arcs is minimal $(<2 \%)$. Hawkesworth et al. (1979) recognize isotope features characteristic of altered oceanic crust in silica- 
Table 22. Analyses of basalts from Hole 448A.

\begin{tabular}{|c|c|c|c|c|c|c|c|c|c|c|c|c|c|c|c|c|}
\hline $\begin{array}{l}\text { Core } \\
\text { Section } \\
\text { Interval }\end{array}$ & $\begin{array}{r}12 \\
1 \\
19\end{array}$ & $\begin{array}{r}15 \\
1 \\
123\end{array}$ & $\begin{array}{r}15 \\
3 \\
143\end{array}$ & $\begin{array}{r}16 \\
3 \\
10\end{array}$ & $\begin{array}{r}17 \\
1 \\
87\end{array}$ & $\begin{array}{r}18 \\
1 \\
77\end{array}$ & $\begin{array}{r}20 \\
1 \\
118\end{array}$ & $\begin{array}{r}20 \\
4 \\
4\end{array}$ & $\begin{array}{r}25 \\
1 \\
23\end{array}$ & $\begin{array}{r}26 \\
2 \\
60\end{array}$ & $\begin{array}{r}28 \\
1 \\
52\end{array}$ & $\begin{array}{r}32 \\
1 \\
47\end{array}$ & $\begin{array}{r}36 \\
4 \\
130\end{array}$ & $\begin{array}{r}37 \\
2 \\
145\end{array}$ & $\begin{array}{r}39 \\
2 \\
140\end{array}$ & $\begin{array}{r}41 \\
1 \\
17\end{array}$ \\
\hline $\mathrm{SiO}_{2}$ & 49.1 & 49.4 & 50.2 & 50.0 & 49.7 & 50.8 & 51.2 & 49.8 & 49.8 & 47.7 & 48.2 & 51.2 & 50.6 & 50.0 & 49.8 & 49.7 \\
\hline $\mathrm{TiO}_{2}$ & 1.49 & 1.11 & 1.08 & 1.09 & 1.15 & 1.12 & 1.08 & 1.29 & 1.28 & 1.22 & 1.01 & 1.41 & 0.95 & 1.63 & 1.36 & 1.25 \\
\hline $\mathrm{Al}_{2} \mathrm{O}_{3}$ & 14.0 & 15.9 & 16.4 & 15.9 & 15.5 & 14.5 & 14.2 & 14.0 & 14.1 & 13.2 & 12.9 & 13.4 & 13.5 & 12.6 & 13.2 & 13.6 \\
\hline $\mathrm{tFe}_{2} \mathrm{O}_{3}$ & 14.23 & 12.25 & 11.89 & 12.23 & 12.76 & 12.72 & 13.66 & 12.61 & 12.61 & 13.02 & 13.59 & 14.07 & 12.84 & 14.52 & 14.25 & 13.44 \\
\hline $\mathrm{MnO}$ & 0.23 & 0.20 & 0.18 & 0.19 & 0.20 & 0.21 & 0.21 & 0.21 & 0.21 & 0.37 & 0.26 & 0.18 & 0.26 & 0.22 & 0.22 & 0.21 \\
\hline $\mathrm{MgO}$ & 4.42 & 4.68 & 4.02 & 4.96 & 4.11 & 4.14 & 4.66 & 4.41 & 6.21 & 6.47 & 9.22 & 6.19 & 8.18 & 6.43 & 5.61 & 6.70 \\
\hline $\mathrm{CaO}$ & 10.64 & 10.12 & 10.16 & 9.79 & 9.72 & 8.93 & 8.32 & 8.88 & 9.32 & 9.93 & 6.38 & 8.29 & 10.33 & 9.01 & 9.21 & 9.15 \\
\hline $\mathrm{Na}_{2} \mathrm{O}$ & 2.69 & 3.47 & 3.16 & 3.17 & 3.00 & 3.14 & 2.99 & 3.04 & 3.52 & 3.48 & 2.58 & 3.10 & 2.62 & 2.76 & 4.55 & 2.64 \\
\hline $\mathrm{K}_{2} \mathrm{O}$ & 0.69 & 0.94 & 1.39 & 1.05 & 1.33 & 1.82 & 2.14 & 1.66 & 0.63 & 1.63 & 2.03 & 1.47 & 0.16 & 1.16 & 1.11 & 1.28 \\
\hline $\mathrm{P}_{2} \mathrm{O}_{5}$ & 0.12 & 0.13 & 0.21 & 0.12 & 0.26 & 0.11 & 0.07 & 0.16 & 0.29 & 0.32 & 0.33 & 0.10 & 0.08 & 0.12 & 0.16 & 0.17 \\
\hline Total & 97.63 & 98.21 & 98.68 & 98.57 & 97.70 & 97.43 & 98.45 & 96.04 & 97.87 & 97.34 & 96.48 & 99.45 & 99.53 & 98.43 & 99.37 & 98.11 \\
\hline
\end{tabular}

\section{Trace Elements (ppm)}

$\begin{array}{lrrr}\mathrm{Ni} & 11 & 18 & 16 \\ \mathrm{Cr} & 32 & 25 & 33 \\ \mathrm{Zn} & 106 & 90 & 89 \\ \mathrm{Ga} & 20 & 19 & 22 \\ \mathrm{Rb} & 6 & 8 & 12 \\ \mathrm{Sr} & 146 & 178 & 179 \\ \mathrm{Y} & 29 & 29 & 32 \\ \mathrm{Zr} & 47 & 71 & 73 \\ \mathrm{Nb} & <1 & <1 & <1 \\ \mathrm{Ba} & 33 & 34 & 70 \\ \mathrm{La} & 7 & 5 & 5 \\ \mathrm{Ce} & 10 & 12 & 11 \\ \mathrm{Nd} & 8 & 10 & 8 \\ \mathrm{~Pb} & 3 & 4 & 6 \\ \mathrm{Th} & 1 & <1 & <1\end{array}$

$\begin{array}{rrr}19 & 16 & 14 \\ 29 & 38 & 18 \\ 89 & 93 & 95 \\ 21 & 19 & 19 \\ 6 & 12 & 21 \\ 175 & 181 & 167 \\ 28 & 36 & 36 \\ 68 & 69 & 70 \\ <1 & <1 & <1 \\ 34 & 39 & 48 \\ 5 & 6 & 6 \\ 12 & 15 & 11 \\ 9 & 11 & 12 \\ 5 & 3 & 5 \\ <1 & 1 & 2\end{array}$

$\begin{array}{rrrr}17 & 15 & 12 & 15 \\ 13 & 20 & 46 & 29 \\ 98 & 122 & 134 & 87 \\ 18 & 19 & 21 & 21 \\ 21 & 20 & 2 & 13 \\ 144 & 169 & 198 & 167 \\ 30 & 36 & 64 & 32 \\ 68 & 78 & 72 & 46 \\ <1 & <1 & <1 & <1 \\ 54 & 38 & 33 & 60 \\ 5 & 7 & 8 & 5 \\ 13 & 13 & 23 & 9 \\ 11 & 11 & 15 & 7 \\ 1 & 3 & 3 & 4 \\ <1 & 1 & <1 & <1\end{array}$

16
41
88
19
16
137
25
35
$<1$
35
5
9
6
4
2

$\begin{array}{rrr}5 & 111 & 25 \\ 17 & 309 & 36 \\ 111 & 89 & 118 \\ 19 & 21 & 20 \\ 19 & <1 & 14 \\ 155 & 173 & 157 \\ 27 & 19 & 27 \\ 49 & 40 & 52 \\ <1 & <1 & <1 \\ 62 & 23 & 38 \\ 4 & 5 & 6 \\ 8 & 8 & 9 \\ 8 & 6 & 8 \\ 3 & 5 & 4 \\ <1 & <1 & <1\end{array}$

$\begin{array}{rr}6 & 10 \\ 19 & 23 \\ 100 & 99 \\ 20 & 20 \\ 10 & 11 \\ 212 & 157 \\ 29 & 25 \\ 62 & 39 \\ <1 & <1 \\ 46 & 29 \\ 6 & 6 \\ 12 & 11 \\ 9 & 7 \\ 2 & 4 \\ 1 & <1\end{array}$

CIPW Norm

\begin{tabular}{|c|c|c|c|c|c|c|c|c|c|c|c|c|c|c|c|c|}
\hline Q & 0.1 & 0.0 & 0.0 & 0.0 & 0.0 & 0.0 & 0.0 & 0.0 & 0.0 & 0.0 & 0.0 & 0.0 & 0.0 & 0.0 & 0.0 & 0.0 \\
\hline Or & 4.2 & 5.6 & 8.3 & 6.3 & 8.0 & 11.0 & 12.8 & 19.2 & 3.8 & 9.9 & 12.4 & 8.7 & 1.0 & 7.0 & 6.6 & 7.7 \\
\hline $\mathrm{Ab}$ & 23.1 & 29.9 & 27.1 & 27.2 & 26.0 & 27.3 & 25.7 & 26.8 & 30.4 & 20.7 & 22.6 & 26.4 & 22.3 & 23.7 & 27.9 & 22.8 \\
\hline An & 24.9 & 25.5 & 26.8 & 26.5 & 25.4 & 20.5 & 19.2 & 20.3 & 21.1 & 16.0 & 18.2 & 18.5 & 24.8 & 18.8 & 12.3 & 21.9 \\
\hline $\mathrm{Ne}$ & 0.0 & 0.0 & 0.0 & 0.0 & 0.0 & 0.0 & 0.0 & 0.0 & 0.0 & 5.2 & 0.0 & 0.0 & 0.0 & 0.0 & 5.8 & 0.0 \\
\hline Di & 23.9 & 20.7 & 19.2 & 18.3 & 18.7 & 20.3 & 18.7 & 20.5 & 20.0 & 27.0 & 10.2 & 18.4 & 21.5 & 21.4 & 27.3 & 19.3 \\
\hline Hy & 16.9 & 0.1 & 5.6 & 8.4 & 10.9 & 10.3 & 11.7 & 11.9 & 8.4 & 0.0 & 12.3 & 15.1 & 21.8 & 17.5 & 0.0 & 15.4 \\
\hline Ol & 0.0 & 12.5 & 7.3 & 7.7 & 4.7 & 4.6 & 6.0 & 3.9 & 9.7 & 14.7 & 17.8 & 6.2 & 3.3 & 4.2 & 13.3 & 6.6 \\
\hline $\mathrm{Mt}$ & 2.5 & 2.2 & 2.1 & 2.2 & 2.3 & 2.3 & 2.4 & 2.3 & 2.2 & 2.3 & 2.4 & 2.5 & 2.2 & 2.6 & 2.5 & 2.4 \\
\hline II & 2.9 & 2.1 & 2.1 & 2.1 & 2.2 & 2.2 & 2.1 & 2.6 & 2.5 & 2.4 & 2.0 & 2.7 & 1.8 & 3.1 & 2.6 & 2.4 \\
\hline Ap & 0.3 & 0.3 & 0.5 & 0.3 & 0.6 & 0.3 & 0.2 & 0.4 & 0.7 & 0.8 & 0.8 & 0.2 & 0.2 & 0.3 & 0.4 & 0.4 \\
\hline Unit & & L12 & L12 & L13 & L13 & L14 & L14 & L14 & L15 & L16 & L18 & L20 & L22 & L23 & L24 & L26 \\
\hline
\end{tabular}

undersaturated volcanics from the Lesser Antilles. Because these rocks are highly unlikely to have been derived by actual melting of the subducted oceanic crust, enrichment of $\mathrm{Sr}^{87}$ and LFS elements is most likely to have been caused by the release of these components during dehydration of the subducted lithosphere. Saunders et al. (in press) believe that transportation of LFS ions from the descending slab into the overlying mantle wedge results in the high LFS/HFS element ratios characteristic of orogenic magmas.

There is a strong argument that island-arc tholeiites may be generated by the partial melting of "wet" mantle peridotite. Melting would be triggered by the lowering of the solidus accompanying the influx of fluids driven off the descending slab. These fluids would enrich the overlying peridotite source with LFS elements and radiogenic $\mathrm{Sr}$ derived mainly by the breakdown of hydrous secondary minerals in altered oceanic crust. Subsequent fractional crystallization initially of olivine and, later, plagioclase, clinopyroxene, and amphibole would generate a spectrum of radiogenic and LFSelement-enriched basalts and andesites with depleted or flat REE patterns.
However, there remain a number of problems with a "mantle-source" model for island-arc tholeiites. The evolved nature of IATs (i.e., higher $\mathrm{FeO} / \mathrm{MgO}$, and low $\mathrm{Cr}$ and $\mathrm{Ni}$ contents) is compatible with derivation from an upper mantle source only if considerable lowpressure fractionation has occurred. Extensive crystal fractionation, however, is not supported by the extremely low abundances of HFS elements such as $\mathrm{Zr}, \mathrm{Y}$, $\mathrm{Nb}$, and the REE that characterize arc tholeiites. Furthermore, $\mathrm{Cr}$ and $\mathrm{Ni}$ contents of arc tholeiites are substantially lower than mantle-derived ferrobasalts, which are similar in composition to IATs in terms of $\mathrm{FeO} / \mathrm{MgO}, \mathrm{CaO}$, and $\mathrm{Al}_{2} \mathrm{O}_{3}$ contents. To illustrate this, a MOR ferrobasalt from the East Pacific Rise (Mattey and Muir, in press) with a similar $\mathrm{FeO} / \mathrm{MgO}$ ratio to the $o l$-basalts from the PKR is plotted on Figure 40. Although the PKR arc tholeiites are similar to the MOR ferrobasalt in terms of the elements $\mathrm{Ca}$ to $\mathrm{Mg}$ on Figure 40 , abundances of $\mathrm{Cr}, \mathrm{Ni}$, and the HFS elements Ti to $\mathrm{P}$ are all signficantly lower in the arc tholeiites. The extremely low $\mathrm{Cr}$ and $\mathrm{Ni}$ contents of IATs could be at least in part a function of the high $\mathrm{FeO} / \mathrm{MgO}$ ratios. Yet compared to other basalt magmas, initially formed as 


\begin{tabular}{|c|c|c|c|c|c|c|c|c|c|c|c|c|c|c|c|c|}
\hline 41 & 41 & 44 & 45 & 46 & 47 & 47 & 50 & 51 & 52 & 52 & 54 & 57 & 58 & 59 & 62 & 65 \\
\hline 2 & 4 & 2 & 2 & 2 & 1 & 2 & 2 & 2 & 1 & 2 & 3 & 1 & 3 & 2 & 1 & 1 \\
\hline 58 & 4 & 55 & 22 & 82 & 108 & 106 & 35 & 134 & 77 & 46 & 115 & 96 & 50 & 85 & 84 & 81 \\
\hline 49.9 & 50.5 & 54.5 & 52.1 & 54.7 & 48.3 & 55.0 & 53.3 & 54.8 & 51.1 & 53.8 & 54.1 & 55.2 & 48.3 & 51.5 & 50.6 & 52.2 \\
\hline 1.14 & 1.43 & 1.49 & 1.36 & 1.21 & 1.55 & 1.23 & 1.45 & 1.27 & 1.48 & 1.55 & 1.25 & 1.28 & 1.66 & 1.68 & 1.00 & 1.17 \\
\hline 12.6 & 13.1 & 13.0 & 13.9 & 13.5 & 13.9 & 13.5 & 12.8 & 12.8 & 12.9 & 13.2 & 13.6 & 12.9 & 11.9 & 13.5 & 15.9 & 13.3 \\
\hline 14.35 & 14.16 & 12.92 & 12.51 & 13.19 & 15.91 & 13.77 & 13.87 & 13.63 & 14.35 & 13.56 & 13.00 & 13.46 & 15.94 & 13.28 & 11.07 & 13.39 \\
\hline 0.20 & 0.22 & 0.22 & 0.19 & 0.18 & 0.25 & 0.18 & 0.24 & 0.20 & 0.22 & 0.25 & 0.21 & 0.18 & 0.19 & 0.21 & 0.15 & 0.22 \\
\hline 7.46 & 7.26 & 5.85 & 6.16 & 5.71 & 3.84 & 5.59 & 5.44 & 5.97 & 6.48 & 4.66 & 5.78 & 6.01 & 7.39 & 5.80 & 5.76 & 5.91 \\
\hline 9.02 & 8.94 & 7.55 & 9.48 & 7.75 & 9.52 & 7.74 & 8.33 & 7.69 & 8.76 & 8.43 & 8.58 & 7.76 & 8.91 & 9.54 & 10.71 & 9.04 \\
\hline 2.79 & 3.02 & 2.94 & 2.46 & 2.81 & 2.92 & 2.84 & 2.55 & 2.58 & 2.48 & 2.69 & 2.61 & 2.63 & 2.53 & 2.92 & 2.29 & 2.63 \\
\hline 0.81 & 0.50 & 0.36 & 0.20 & 0.34 & 0.79 & 0.32 & 0.30 & 0.25 & 0.10 & 0.34 & 0.31 & 0.37 & 0.20 & 0.28 & 0.20 & 0.19 \\
\hline 0.10 & 0.12 & 0.12 & 0.09 & 0.10 & 0.41 & 0.10 & 0.11 & 0.09 & 0.11 & 0.12 & 0.09 & 0.10 & 0.18 & 0.12 & 0.08 & 0.08 \\
\hline 98.34 & 99.27 & 99.00 & 98.49 & 99.48 & 97.35 & 100.25 & 98.38 & 99.22 & 97.90 & 98.65 & 99.54 & 99.85 & 97.19 & 98.99 & 97.78 & 98.06 \\
\hline 16 & 9 & 6 & 12 & 2 & 11 & 3 & 10 & 1 & 13 & 9 & 11 & 2 & 13 & 16 & 16 & 16 \\
\hline 69 & 17 & 18 & 31 & 13 & 14 & 13 & 25 & 12 & 34 & 31 & 21 & 11 & 110 & 40 & 31 & 34 \\
\hline 99 & 113 & 110 & 95 & 93 & 128 & 91 & 105 & 119 & 96 & 113 & 113 & 104 & 112 & 122 & 75 & 99 \\
\hline 18 & 18 & 17 & 19 & 21 & 19 & 20 & 20 & 20 & 18 & 19 & 19 & 19 & 20 & 19 & 20 & 22 \\
\hline 10 & 3 & 2 & 1 & 3 & 9 & 1 & $<1$ & 2 & $<1$ & 1 & 2 & 2 & $<1$ & 2 & $<1$ & $<1$ \\
\hline 169 & 207 & 212 & 163 & 154 & 177 & 152 & 152 & 153 & 153 & 152 & 165 & 161 & 164 & 172 & 225 & 169 \\
\hline 22 & 28 & 24 & 23 & 26 & 47 & 27 & 30 & 30 & 28 & 32 & 25 & 29 & 33 & 31 & 20 & 24 \\
\hline 42 & 60 & 73 & 43 & 53 & 56 & 53 & 47 & 50 & 44 & 54 & 51 & 58 & 58 & 57 & 56 & 44 \\
\hline$<1$ & $<1$ & $<1$ & $<1$ & $<1$ & $<1$ & $<1$ & $<1$ & $<1$ & $<1$ & $<1$ & $<1$ & $<1$ & $<1$ & $<1$ & 1 & $<1$ \\
\hline 41 & 38 & 79 & 49 & 57 & 52 & 60 & 57 & 60 & 50 & 61 & 58 & 70 & 31 & 72 & 55 & 51 \\
\hline 5 & 6 & 8 & 5 & 7 & 8 & 8 & 6 & 6 & 4 & 4 & 6 & 7 & 7 & 6 & 4 & 5 \\
\hline 6 & 13 & 11 & 7 & 9 & 11 & 9 & 11 & 8 & 8 & 10 & 6 & 8 & 9 & 6 & 9 & 8 \\
\hline 6 & 11 & 9 & 5 & 8 & 11 & 7 & 10 & 8 & 9 & 10 & 7 & 8 & 10 & 8 & 6 & 7 \\
\hline 5 & 5 & 2 & 3 & 3 & 3 & 4 & 3 & 6 & 1 & 3 & 4 & 4 & 4 & 3 & 4 & 5 \\
\hline 1 & 1 & $<1$ & 4 & $<1$ & $<1$ & 1 & $<1$ & $<1$ & 1 & 1 & 2 & $<1$ & 2 & $<1$ & $<1$ & $<1$ \\
\hline 0.0 & 0.0 & 7.9 & 5.3 & 8.1 & 0.0 & 8.0 & 8.0 & 9.4 & 4.4 & 8.8 & 7.5 & 9.0 & 0.0 & 2.4 & 3.3 & 5.1 \\
\hline 4.8 & 3.0 & 2.2 & 1.2 & 2.0 & 4.8 & 1.9 & 1.8 & 1.5 & 0.6 & 2.0 & 1.9 & 2.2 & 1.2 & 2.3 & 1.2 & 1.1 \\
\hline 24.0 & 25.7 & 25.1 & 21.1 & 23.9 & 25.4 & 24.0 & 21.9 & 22.0 & 21.4 & 23.1 & 22.2 & 22.3 & 22.0 & 25.0 & 19.8 & 22.7 \\
\hline 19.8 & 20.9 & 21.5 & 26.8 & 23.3 & 23.0 & 23.0 & 22.9 & 22.7 & 24.2 & 23.4 & 24.7 & 22.3 & 21.2 & 22.9 & 33.4 & 24.3 \\
\hline 0.0 & 0.0 & 0.0 & 0.0 & 0.0 & 0.0 & 0.0 & 0.0 & 0.0 & 0.0 & 0.0 & 0.0 & 0.0 & 0.0 & 0.0 & 0.0 & 0.0 \\
\hline 20.7 & 19.1 & 13.0 & 16.9 & 12.3 & 19.3 & 12.2 & 15.3 & 12.6 & 16.2 & 15.3 & 14.6 & 13.0 & 19.7 & 20.0 & 16.9 & 17.4 \\
\hline 17.5 & 20.4 & 23.9 & 22.5 & 24.5 & 16.8 & 24.7 & 23.2 & 25.6 & 26.2 & 20.6 & 23.2 & 25.0 & 25.8 & 20.4 & 20.3 & 23.3 \\
\hline 6.9 & 4.2 & 0.0 & 0.0 & 0.0 & 2.4 & 0.0 & 0.0 & 0.0 & 0.0 & 0.0 & 0.0 & 0.0 & 2.3 & 0.0 & 0.0 & 0.0 \\
\hline 2.5 & 2.5 & 2.3 & 2.2 & 2.3 & 2.8 & 2.4 & 2.5 & 2.4 & 2.6 & 2.4 & 2.3 & 2.3 & 2.9 & 2.3 & 2.0 & 2.4 \\
\hline 2.2 & 2.7 & 2.9 & 2.6 & 2.3 & 3.0 & 2.3 & 2.8 & 2.4 & 2.9 & 3.0 & 2.4 & 2.4 & 3.2 & 3.2 & 1.9 & 2.3 \\
\hline 0.2 & 0.3 & 0.3 & 0.2 & 0.2 & 1.0 & 0.2 & 0.3 & 0.2 & 0.3 & 0.3 & 0.2 & 0.2 & 0.2 & 0.3 & 0.2 & 0.2 \\
\hline L27 & L27 & L31 & L31 & L31 & L33 & L33 & L35 & L37 & L39 & L39 & L41 & L43 & L45 & L47 & L49 & L51 \\
\hline
\end{tabular}

partial melts of an upper mantle source that have undergone extensive fractional crystallization, $\mathrm{Cr}$ and $\mathrm{Ni}$ contents of arc tholeiites appear to be anomalously low.

Another feature of the PKR island-arc tholeiites (which is not entirely compatible with extensive fractional crystallization required to generate high $\mathrm{FeO} /$ $\mathrm{MgO}$ ratios and low $\mathrm{Cr}$ and $\mathrm{Ni}$ contents) is the wide range of $\mathrm{Ti} / \mathrm{Zr}, \mathrm{Y} / \mathrm{Zr}$, and $\mathrm{Ce} / \mathrm{Yb}$ ratios (Figs. 33, 34, and 39) that characterize these rocks. Unless $\mathrm{Ti}-, \mathrm{Zr}-$, or Y-bearing phases were involved during fractional crystallization the wide range of these inter-element ratios implies that the main petrochemical groups recognized in Holes 448 and $448 \mathrm{~A}$ cannot be comagmatic. Relatively few igneous units drilled on the PKR can be related by fractional crystallization.

If the PKR arc tholeiites are derived from a mantle source, then either the peridotite source must have been previously depleted in HFS elements (particularly $\mathrm{Nb}$, $\mathrm{Ta}$, and $\mathrm{Zr}$ ) or these elements were retained in a minor phase during melting. The possibility of residual minor phases during partial melting of eclogite to form calc-alkalic andesite was discussed by Gill (1974).
Phases such as apatite, rutile, sphene, zircon, perovskite, titanoclinohumite, or pyrrhotite-pentlandite solid solution may exist at upper-mantle pressures and temperatures. Hellman and Green (1979) have suggested that rutile and sphene may be stabilized during hydrous melting at mantle pressures and may explain the low abundances of $\mathrm{Ti}, \mathrm{Zr}, \mathrm{Hf}, \mathrm{Nb}$, and the REE in arc tholeiites. Refractory zircon would likewise affect $\mathrm{Zr}$, Hf, P, and REE contents. The pyrrhotite-pentlandite solid-solution group of sulphides can remain stable above the basalt solidus (e.g., MacLean, 1969). If this phase were present and stable during melting, it could possibly provide an interesting explanation for low $\mathrm{Ni}$ (and $\mathrm{Cr}$ ?) abundances in arc tholeiites.

In many ways, the gross geochemical characteristics of the subducted oceanic lithosphere provides a more acceptable source material for arc-tholeiite magmas. Low abundances of HFS elements and typically flat or light (L)REE depleted REE patterns typical of MORB could be directly transferred by partial melting. Studies of ophiolite complexes (e.g., Bonatti et al., 1976; Spooner et al., 1974) and direct observation at oceanic spreading centers (e.g., Hoffert et al., 1978; Natland et 


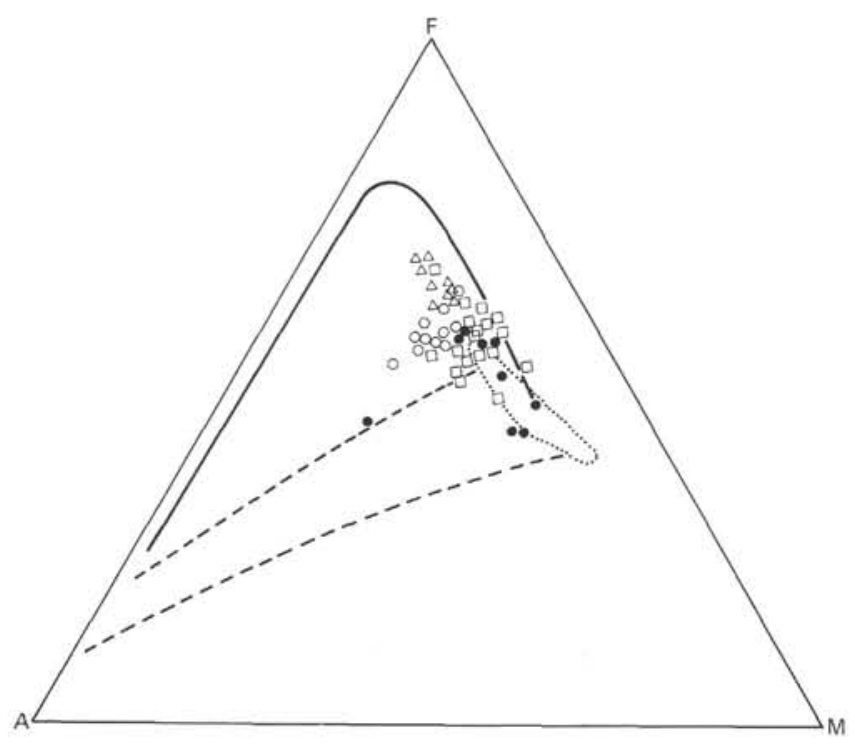

Figure 23. AFM $\left(\mathrm{Na}_{2} \mathrm{O}+\mathrm{K}_{2} \mathrm{O}-\mathrm{FeO} * / \mathrm{MgO}\right)$ plot for representative data from Site 448 (open symbols) and from Site 451 (closed symbol). (Open triangles $=O l$-basalts; open circles $=O p x-$ basalts; open squares $=C p x$-basalts; closed circles $=$ all Site 451 basalts. Site 447 [West Philippine Basin] basalts plot in the dotted field; the solid line represents the Skaergaard fractionation trend; dashed lines represent the Cascades fractionation trend.)

al., 1979) have provided strong evidence for large hydrothermal convection cells at ridge crests. These result in the relatively uniform alteration of Oceanic Layer 2 and Layer 3 to greenschist or amphibolite facies and enrichment of rock in radiogenic (seawater) $\mathrm{Sr}$ (Dasch et al., 1973; Hart et al., 1974). Sr-isotope ratios for altered ocean-floor basalts overlap those of islandarc tholeiites; direct remelting of hydrous altered basalt or gabbro would also account for the more radiogenic nature of IATs and the overall enrichment of LFS elements. Additional LFS-element input may also be derived from a small quantity of trapped sediment in the descending slab. High degrees of melting of ocean-floor basalt would also result in relatively iron-rich melts containing low abundances of $\mathrm{Cr}$ and $\mathrm{Ni}$.

Fitton (1971) has suggested that subducted oceanic crust (amphibolite) could be a source for arc-tholeiite magmas. He argues that reactions involving the dehydration and breakdown of amphibole might persist to depths approaching $120 \mathrm{~km}$ below island arcs. Geochemical and isotopic studies of the Banda arc (Magaritz et al., 1978; Whitford and Jezek, 1979) have indicated that subducted sediments have melted during magma genesis at Benioff zone depths of $\sim 150 \mathrm{~km}$. This implies that the temperature at the top of the subducted slab at this depth is probably at least $750^{\circ} \mathrm{C}$. This is close to the wet solidus of amphibolite at such pressures, and temperatures are probably high enough to melt basaltic crust at the top surface of the slab at depths $\sim 150 \mathrm{~km}$. Anderson et al. (1978) has suggested that frictional heating may occur in the subduction zone at young island arcs, particularly during the early stages of subduction. Attainment of high degrees of partial melting might be assisted by the stripping-off of rheologically weak Layer 2 (and Layer 3 ?) and intimate mixing of relatively small blocks of ocean crust (on a 10-100 m scale?) with hot mantle peridotite. Many amphiboles contain $\mathrm{Ti}$, and because $\mathrm{Zr}^{4+}, \mathrm{Nb}^{4+}$, (and $\mathrm{Ta}^{4+}$ ) would follow $\mathrm{Ti}^{4+}$, perhaps amphiboles contain significant quantities of these elements. Partition coefficients quoted in the literature for these highly charged ions vary from 0.5 to $\sim 1$ (e.g., Pearce and Norry, 1979) and would probably be even higher under hydrous conditions (Saunders et al., in press). Thus residual amphibole, during partial melting, is a posssible explanation for low abundances of HFS elements in IATs. Other minor phases likely to be present in amphibolitized oceanic crust include rutile, sphene, and possibly zircon. Hellman and Green (1979) have demonstrated that rutile and sphene are stable during hydrous melting and would thus retain $\mathrm{Ti}, \mathrm{Nb}, \mathrm{Ta}$, and $\mathrm{Zr}(?)$ in the source. Residual zircons found in many granites and ortho-gneisses (e.g., Buma et al., 1971; McCarthy and Kable, 1978; Watson, 1979) testify to the stability of this phase (which may retain $\mathrm{Nb}$ and $\mathrm{Ta}$ as well as $\mathrm{Zr}$ ) during partial melting.

To conclude, two alternative models for the genesis of IATs have been discussed. The more orthodox model requires IATs to be produced as hydrous partial melts of the superjacent mantle wedge, accompanied by an influx of LFS elements and radiogenic $\mathrm{Sr}$ during dehydration of the descending lithospheric slab. Extensive fractional crystallization is required to generate dominantly Fe-rich, $\mathrm{Cr}$ - and Ni-poor IATs. Relatively few of the $\mathbf{4 6}$ igneous units drilled on the PKR are comagmatic, however, which implies that partial melting is the dominant process in the genesis of these basalts. Anomalous concentrations of many HFS elements and low abundances of REEs can only be explained if the superjacent mantle was previously depleted in these elements or if unusual residual minor phases were present and stabilized (rutile, sphene, titanoclinohumite, zircon, apatite, etc.). Furthermore, abundances of $\mathrm{Cr}$ and $\mathrm{Ni}$ appear to be anomalously low compared to other fractionated mantle-derived basalts with similar major-element chemistry ( $\mathrm{FeO} / \mathrm{MgO}$ ratio etc.).

Alternatively, many geochemical and isotopic properties of island-arc tholeiites would perhaps be better explained if they had been generated by the direct remelting of descending lithospheric slab material. Moderate to high degrees of melting of basaltic crust might produce relatively iron-rich magmas with low abundances of $\mathrm{Cr}$ and $\mathrm{Ni}$. Involvement of hydrothermally altered crust could result in slightly higher abundances of LFS elements and radiogenic Sr, whereas abundances of the REEs and other minor and trace elements would be similar to those of MORB. Minor phases such as rutile, sphene, and zircon may be residual during melting and would explain the anomalously low abundances of $\mathrm{Zr}, \mathrm{Nb}$ in IATs (and Ta, see Wood et al., this volume). This model relieves the necessity of extensive fractional crystallization and explations many of the geochemical properties of IATs without resorting to special mantle source compositions or mineralogies. 
Table 23. Representative analyses of basalts from the Philippine Sea active and remnant island arcs.

\begin{tabular}{|c|c|c|c|c|c|c|c|c|c|c|c|}
\hline \multirow[b]{2}{*}{ Samples } & \multicolumn{3}{|c|}{$\begin{array}{l}\text { Palau-Kyushu } \\
\text { Ridge }\end{array}$} & \multirow{2}{*}{$\frac{\text { WMR }}{4^{d}}$} & \multicolumn{3}{|c|}{ Mariana Arc } & \multicolumn{2}{|l|}{ Japan } & \multicolumn{2}{|c|}{ Jakeš and Gill } \\
\hline & $1^{\mathrm{a}}$ & $2^{b}$ & $3 \mathrm{c}$ & & GU-1e & $9-1 A^{f}$ & $1-3 \mathrm{~g}$ & Thol.h & $\mathrm{CA}^{\mathrm{i}}$ & IATSj & CASj \\
\hline $\mathrm{SiO}_{2}$ & 49.0 & 50.0 & 51.7 & 49.9 & 50.9 & 48.7 & 50.9 & 50.0 & 53.8 & $45-70$ & $53-70$ \\
\hline $\mathrm{TiO}_{2}$ & 1.57 & 1.11 & 1.34 & 0.71 & 0.76 & .49 & 0.80 & 0.84 & 0.95 & $0.5-1.5$ & $0.5-1.2$ \\
\hline $\mathrm{Al}_{2} \mathrm{O}_{3}$ & 14.1 & 15.3 & 13.2 & 18.2 & 19.4 & 20.0 & 16.6 & 15.71 & 17.79 & $14-19$ & $16-19$ \\
\hline $\mathrm{tFeO}^{\mathrm{s}}$ & 13.93 & 11.09 & 12.80 & 8.71 & 9.57 & 8.47 & 11.02 & 11.46 & 8.80 & - & - \\
\hline $\mathrm{MnO}$ & 0.24 & 0.19 & 0.22 & 0.25 & 0.16 & 0.16 & 0.22 & 0.27 & 0.19 & - & - \\
\hline $\mathrm{MgO}$ & 4.16 & 4.54 & 6.57 & 5.75 & 4.67 & 6.19 & 5.10 & 7.37 & 5.87 & - & - \\
\hline $\mathrm{CaO}$ & 9.57 & 9.73 & 8.58 & 10.88 & 11.42 & 13.32 & 10.46 & 11.95 & 8.79 & - & - \\
\hline $\mathrm{Na}_{2} \mathrm{O}$ & 2.94 & 3.55 & 2.86 & 2.44 & 2.37 & 1.57 & 2.57 & 1.47 & 2.76 & - & - \\
\hline $\mathrm{K}_{2} \mathrm{O}$ & 0.88 & 1.38 & 0.70 & 0.73 & 0.40 & 0.37 & 0.73 & 0.24 & 0.62 & - & - \\
\hline $\mathrm{P}_{2} \mathrm{O}_{5}$ & 0.23 & 0.14 & 0.15 & 0.14 & 0.13 & 0.12 & 0.17 & 0.09 & - & & \\
\hline $\mathrm{FeO} / \mathrm{MgO}$ & 3.34 & 2.44 & 1.97 & 1.51 & 1.95 & 1.37 & 2.16 & 1.55 & 1.50 & & \\
\hline $\mathrm{Ni}$ & 13 & 16 & 10 & 8 & - & 26 & 13 & - & - & $0-30$ & 18 \\
\hline $\mathrm{Cr}$ & 2 & 25 & 26 & 33 & 30 & 28 & 14 & - & - & $0-50$ & 56 \\
\hline $\mathrm{Rb}$ & 10 & 13 & 7 & 9 & 6 & 8 & 14 & 5 & 14 & $3-10$ & 30 \\
\hline $\mathrm{Sr}$ & 163 & 171 & 167 & 478 & - & 305 & 342 & 200 & 550 & $100-200$ & 380 \\
\hline $\mathrm{Y}$ & 37 & 31 & 28 & 19 & - & - & - & 12 & 15 & - & - \\
\hline $\mathrm{Zr}$ & 48 & 71 & 57 & 45 & - & 45 & 51 & 22 & 40 & - & - \\
\hline $\mathrm{Nb}$ & 1 & 1 & 1 & 3 & - & - & - & 0.7 & 1.4 & - & - \\
\hline $\mathrm{Ba}$ & 53 & 47 & 59 & 184 & 134 & 86 & 142 & 110 & 300 & $50-150$ & 270 \\
\hline $\mathrm{La}$ & 6 & 5 & 6 & 8 & 2.7 & - & - & 1.3 & 10 & $1-6$ & 12 \\
\hline $\mathrm{Ce}$ & 11 & 13 & 9 & 15 & 4.8 & - & - & 3.7 & 23 & - & - \\
\hline Nd & 9 & 10 & 8 & 10 & - & - & - & 3.4 & 13 & - & - \\
\hline $\mathrm{Pb}$ & 4 & 4 & 4 & 5 & - & - & - & 1.9 & 6 & $2-4$ & $3-7$ \\
\hline Th & 1.3 & 1 & 2 & 2 & - & - & - & 0.3 & 1 & 0.5 & 2 \\
\hline $\mathrm{Ti} / \mathrm{Zr}$ & 196 & 93 & 141 & 95 & - & 65 & 94 & 228 & 142 & - & - \\
\hline $\mathrm{Ba} / \mathrm{Zr}$ & 1.1 & 0.7 & 1.0 & 4.1 & - & 1.9 & 2.8 & 5.0 & 7.5 & - & - \\
\hline
\end{tabular}

a 1 = average $o$-basalt from Units L6, L8, Hole 448.

b $2=$ average opx-basalt from Units L12, L13, L14, Holes 448 and 448A.

c $3=$ average $c p x$-basalt, Hole $448 \mathrm{~A}$.

$\mathrm{d}_{4}=$ average WMR (West Mariana Ridge) basalt, Hole 451.

e GU-1 = primitive recent lava, Gugan, N. Marianas (Dixon and Batiza, 1979).

f 9-1A = primitive recent lava, Agrigan, N. Marianas (Stern, 1979).

g 1-3 = recent basalt lava, Agrigan, N. Marianas (Stern, 1979).

h Thol. = average of five aphyric tholeitic (pigeonitic series) basalts from Japan (Aramaki and Ui, in press).

$\mathrm{i}$ CA $=$ average of eight aphyric calc-alkalic (hypersthenic series) basalts (Aramaki and Ui, in press).

$\mathrm{j}$ IATS and CAS = tholeiite series and the calc-alkalic series (Jakeš and Gill, 1970).

The "slab-source" model is perhaps geochemically more realistic, but its main weakness lies in the thermal feasibility of generating large partial melts of Layer 2 or upper Layer 3 crust. Temperatures at the portion of the Benioff zone directly beneath the volcanic line are probably high enough for at least some partial melting of the descending slab, especially during the early stages of the subduction-when the cooler lithosphere has not chilled the hotter overlying peridotite. Additional thermal input might also be obtained at this stage by frictional heating. High degrees of partial melting might be aided by mixing of relatively small blocks of basaltic crust with hot peridotite.

\section{Chemical Evolution of Island-Arc Volcanism in the Philippine Sea}

A detailed synthesis of the tectonic and petrologic history of the South Philippine Sea will not be attempted in this chapter (see Kroenke, Scott et al., this volume). However, it is pertinent to comment on the geochemical differences between the volcanic sections drilled on the Palau-Kyushu and West Mariana ridges and recent lavas from the active Mariana arc.

Clear chemical differences have been demonstrated between the volcanic units from the PKR and WMR (see Table 23 and Figure 41). The older Palau-Kyushu Ridge is found to be a complex structure consisting of pillow lavas and massive lavas, interbedded with thick volcanic breccia. Sills and dikes become common deeper in the section. The sparsely phyric basalts and rare basaltic andesites belong to the Island-Arc Tholeiite Series of Jakeš and Gill (1970) and develop a strong trend of iron enrichment. Rare-earth element contents of these basalts are similar to those of MORB, with flat or slightly LREE depleted patterns. LFS trace and minor elements are enriched (relative to N-MORB) as a result of either remelting altered oceanic crust (in the "slab-source" model) or by enrichment of the overlying mantle wedge by fluid transfer from the slab during dehydration (in the "mantle-source" model). HFS trace and minor elements are depleted in IATs, possibly being retained in the source in minor phases. LFS elements are thus 
Table 24. Analyses of basalts from Hole 451 .

\begin{tabular}{|c|c|c|c|c|c|c|c|c|c|}
\hline Core & 38 & 38 & 45 & 45 & 46 & 53 & 54 & 59 & 102 \\
\hline Section & 1 & 2 & 1 & i & 1 & 2 & 1 & 1 & $\mathrm{CC}$ \\
\hline Interval & 137 & 27 & 29 & 70 & 24 & 3 & 22 & 54 & 11 \\
\hline $\mathrm{SiO}_{2}$ & 50.3 & 49.7 & 48.1 & 48.3 & 50.6 & 48.2 & 48.4 & 57.2 & 48.6 \\
\hline $\mathrm{TiO}_{2}^{2}$ & 0.70 & 0.63 & 0.59 & 0.60 & 0.77 & 0.76 & 0.78 & 0.65 & 0.94 \\
\hline $\mathrm{Al}_{2} \mathrm{O}_{3}$ & 19.0 & 19.0 & 19.8 & 19.8 & 15.8 & 19.4 & 18.4 & 17.7 & 15.3 \\
\hline $\mathrm{tFe}_{2} \mathrm{O}_{3}$ & 10.31 & 10.58 & 9.99 & 10.07 & 11.13 & 8.27 & 8.90 & 7.18 & 10.69 \\
\hline $\mathrm{MnO}^{\circ}$ & 0.18 & 0.19 & 0.18 & 0.18 & 0.17 & 0.11 & 0.13 & 0.15 & 0.28 \\
\hline $\mathrm{MgO}$ & 4.31 & 4.41 & 4.86 & 5.50 & 6.70 & 7.02 & 7.76 & 3.03 & 5.58 \\
\hline $\mathrm{CaO}$ & 10.83 & 11.16 & 12.60 & 12.46 & 9.58 & 11.76 & 10.99 & 8.60 & 9.97 \\
\hline $\mathrm{Na}_{2} \mathrm{O}$ & 2.16 & 2.42 & 2.37 & 2.13 & 2.52 & 2.26 & 2.40 & 3.27 & 2.49 \\
\hline $\mathrm{K}_{2} \mathrm{O}$ & 0.72 & 0.46 & 0.26 & 0.22 & 0.62 & 0.93 & 0.85 & 2.13 & 0.38 \\
\hline $\mathrm{P}_{2} \mathrm{O}_{5}$ & 0.06 & 0.11 & 0.10 & 0.11 & 0.23 & 0.25 & 0.11 & 0.14 & 0.17 \\
\hline Total & 98.57 & 98.65 & 98.89 & 98.91 & 98.18 & 98.91 & 98.73 & 100.12 & 97.33 \\
\hline
\end{tabular}

Trace Elements (ppm)

$\begin{array}{lrrrrrrrrr}\mathrm{Ni} & { }^{3} & <1 & 3 & <1 & 5 & 7 & 13 & 2 & 37 \\ \mathrm{Cr} & 12 & 10 & 11 & 7 & 23 & 20 & 26 & 11 & 174 \\ \mathrm{Zn} & 71 & 84 & 68 & 71 & 66 & 61 & 89 & 68 & 65 \\ \mathrm{Ga} & 20 & 19 & 21 & 20 & 20 & 23 & 21 & 21 & 19 \\ \mathrm{Rb} & 11 & 6 & 2 & 2 & 8 & 4 & 5 & 43 & 4 \\ \mathrm{Sr} & 493 & 484 & 495 & 400 & 539 & 621 & 500 & 520 & 455 \\ \mathrm{Y} & 16 & 18 & 13 & 13 & 22 & 46 & 14 & 25 & 25 \\ \mathrm{Zr} & 38 & 37 & 31 & 31 & 66 & 39 & 34 & 83 & 42 \\ \mathrm{Nb} & 1 & <1 & <1 & <1 & 1 & <1 & <1 & 1 & <1 \\ \mathrm{Ba} & 176 & 162 & 114 & 130 & 186 & 182 & 161 & 446 & 99 \\ \mathrm{La} & 6 & 6 & 4 & 3 & 12 & 13 & 5 & 12 & 11 \\ \mathrm{Ce} & 11 & 12 & 11 & 10 & 23 & 20 & 10 & 21 & 20 \\ \mathrm{Nd} & 9 & 9 & 6 & 8 & 15 & 14 & 5 & 13 & 11 \\ \mathrm{~Pb} & 5 & 6 & 3 & 1 & 7 & 6 & 4 & 6 & 3 \\ \mathrm{Th} & 1 & 2 & <1 & 1 & 4 & 1 & 1 & <1 & <1\end{array}$

\begin{tabular}{lrrrrrrrrr}
\multicolumn{2}{l}{ CIPW Norm } & & & & & & & & \\
Q & 2.5 & 0.7 & 0.0 & 0.0 & 0.7 & 0.0 & 0.0 & 6.5 & 0.0 \\
Or & 4.3 & 2.8 & 1.6 & 1.3 & 3.7 & 5.6 & 5.1 & 12.9 & 2.3 \\
$\mathrm{Ab}$ & 18.5 & 20.8 & 20.3 & 18.2 & 21.7 & 19.3 & 20.6 & 27.6 & 21.6 \\
$\mathrm{An}$ & 40.6 & 40.1 & 43.1 & 44.3 & 30.7 & 40.4 & 37.5 & 27.3 & 30.2 \\
$\mathrm{Ne}$ & 0.0 & 0.0 & 0.0 & 0.0 & 0.0 & 0.0 & 0.0 & 0.0 & 0.0 \\
$\mathrm{Di}$ & 11.4 & 12.9 & 16.2 & 14.6 & 13.5 & 14.0 & 13.9 & 12.2 & 16.0 \\
$\mathrm{Hy}$ & 18.85 & 18.5 & 8.0 & 14.5 & 24.7 & 4.3 & 5.2 & 10.4 & 16.3 \\
$\mathrm{OI}$ & 0.0 & 0.0 & 6.8 & 3.1 & 0.0 & 12.2 & 13.7 & 0.0 & 8.5 \\
$\mathrm{Mt}$ & 1.8 & 1.9 & 1.8 & 1.8 & 2.0 & 1.5 & 1.6 & 1.2 & 1.9 \\
II & 1.3 & 1.2 & 1.1 & 1.1 & 1.5 & 1.5 & 1.5 & 1.2 & 1.8 \\
$\mathrm{Ap}$ & 0.1 & 0.3 & 0.2 & 0.3 & 0.6 & 0.6 & 0.3 & 0.3 & 0.4 \\
\hline
\end{tabular}

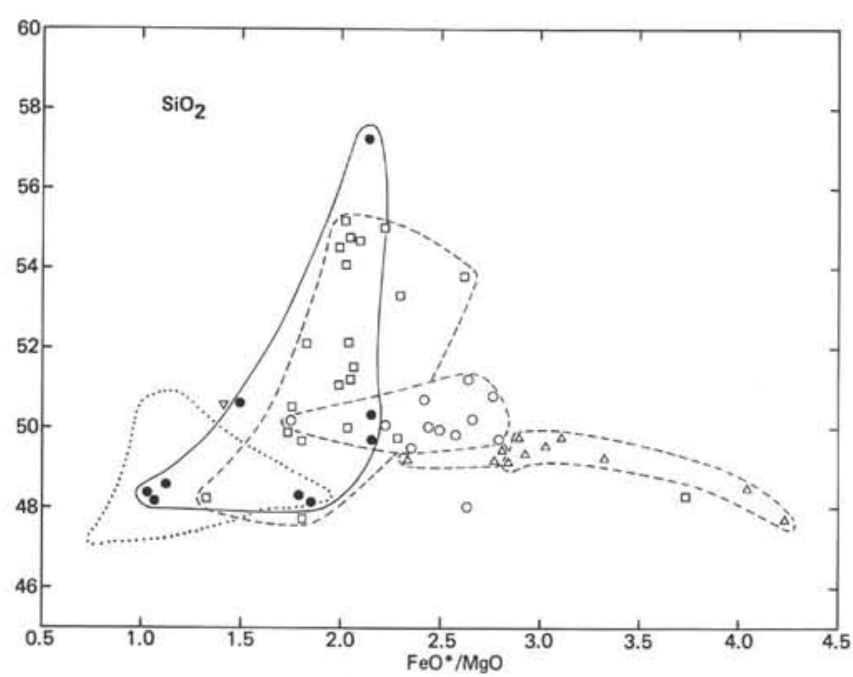

Figure 24. Plot of $\mathrm{SiO}_{2}(\%)$ versus $\mathrm{FeO}^{*} / \mathrm{MgO}$ for basalts from Site 448 on the Palau-Kyushu Ridge (open symbols) and from the West Mariana Ridge (Site 451) (closed symbol). (Open triangles [2 groups] $=\mathrm{Ol}$-basalts from Units $\mathrm{L} 6$ and $\mathrm{L} 8$ [highest $\mathrm{FeO}^{*} / \mathrm{MgO}$ ratios] and from Unit $\mathrm{L} 10$ [lower $\mathrm{FeO}^{*} / \mathrm{MgO}$ ratios]; open circles $=O p x$-basalts [Units L12-L14]; open squares $=C p x$-basalts; upside-down triangle-Ol-basalt from Unit L22. Closed circles [enclosed by solid line] = "calc-alkalic" basalts from Hole 451 (West Mariana Ridge). Site 447 (West Philippine Basin) basalts plots in dotted field. $\mathrm{FeO}^{*}=$ total $\mathrm{Fe}$ as $\mathrm{FeO}$.)

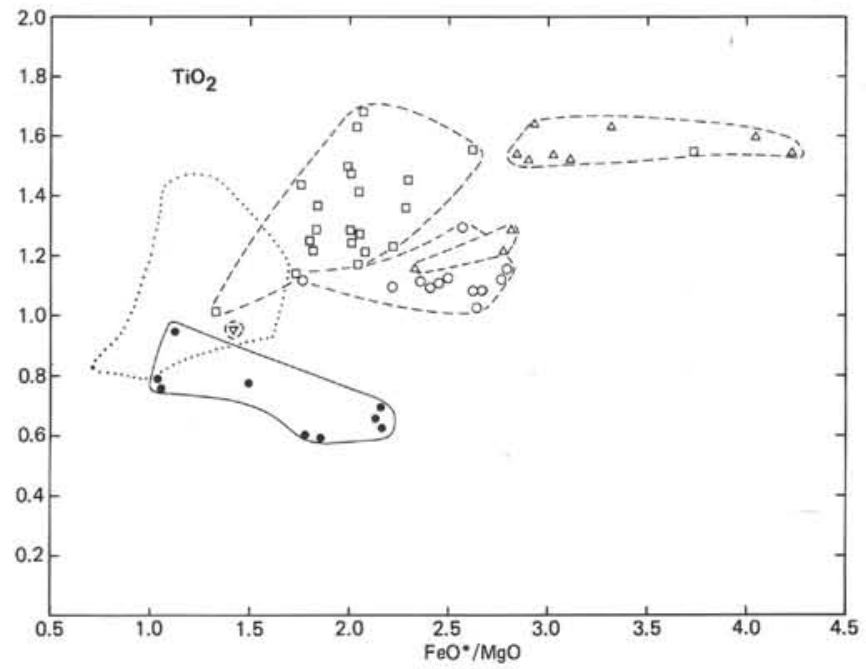

Figure 25. Plot of $\mathrm{TiO}_{2}(\%)$ versus $\mathrm{FeO}^{*} / \mathrm{MgO}$ for basalts from Sites 448 and 451 . (Symbols are the same as those in Fig. 24.)

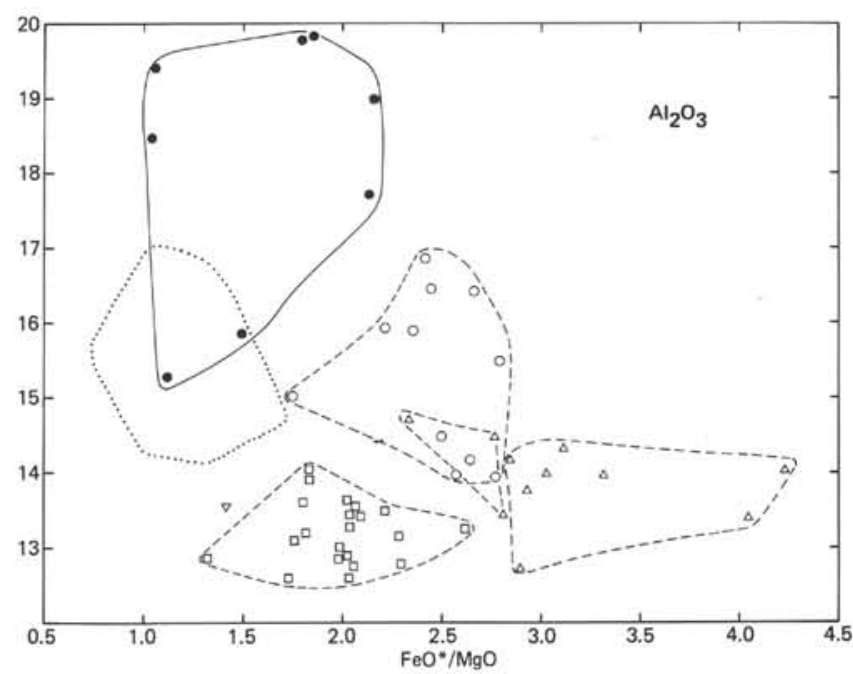

Figure 26. Plot of $\mathrm{Al}_{2} \mathrm{O}_{3}(\%) \mathrm{FeO} * / \mathrm{MgO}$ for basalts from Sites 448 and 451 (same symbols as in Fig. 24).

"decoupled" from HFS elements in the PKR island-arc tholeiites.

The drilled section of the younger West Mariana Ridge revealed a monotonous succession of volcanic tuffs and breccias. Although no igneous units were presented, many clasts from the volcanic breccias were fresh and large enough for analysis. The majority of these clasts were highly porphyritic and contained phenocrysts of magnetite in addition to plagioclase, clinopyroxene, orthopyroxene, and rare olivine. Chemically, these basalts and andesites develop less extensive iron enrichment and are notably richer in aluminum and calcium (Table 23). With light rare-earth-element enriched patterns $\left(\mathrm{Ce}_{\mathrm{N}} / \mathrm{Yb}_{\mathrm{N}} \sim 2\right)$, these rocks show 


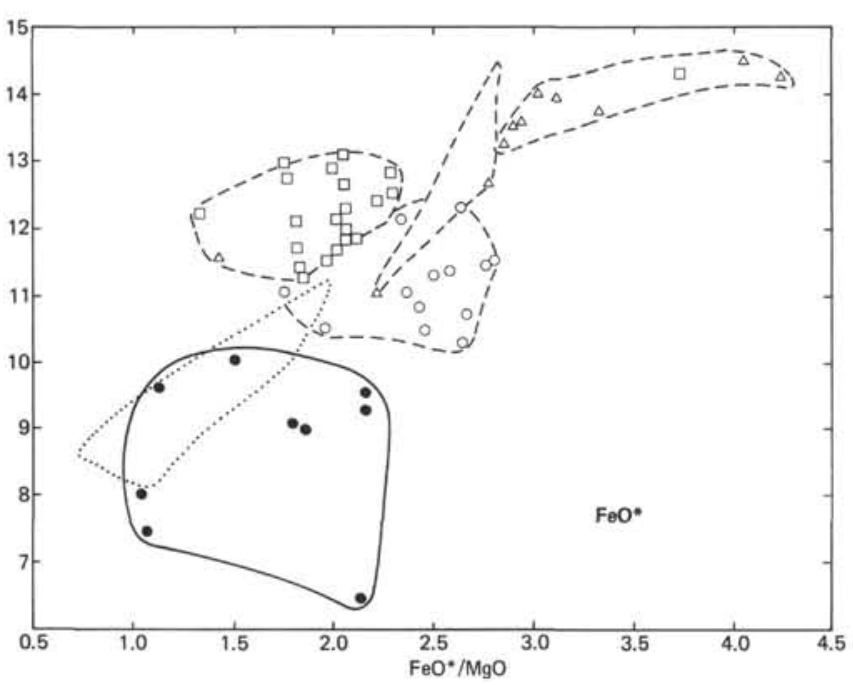

Figure 27. Plot of $\mathrm{FeO}^{*}(\%)$ versus $\mathrm{FeO}^{*} / \mathrm{MgO}$ for basalts from Sites 448 and 451 (same symbols as in Fig. 24).

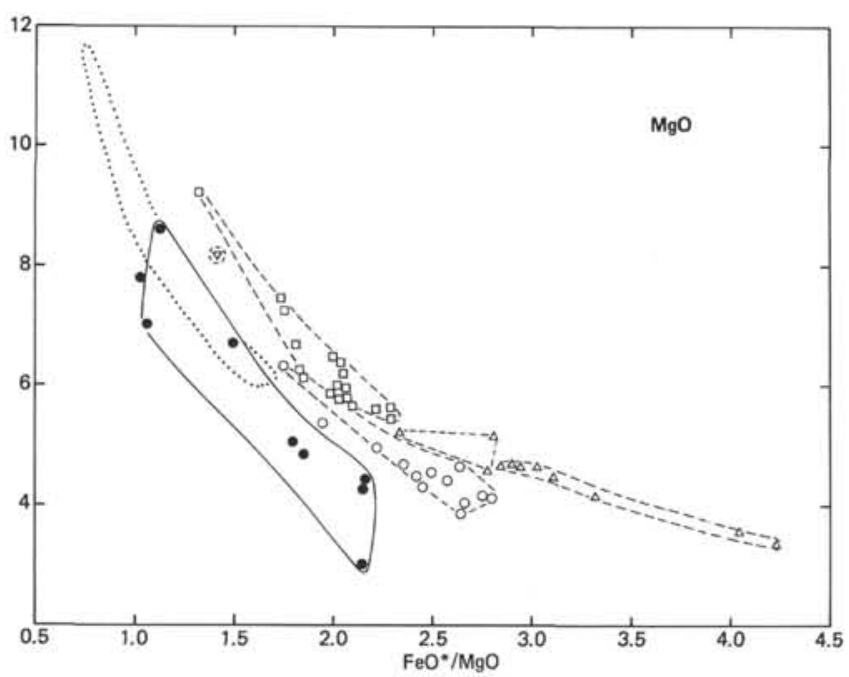

Figure 28. Plot of $\mathrm{MgO}(\%)$ versus $\mathrm{FeO}^{*} / \mathrm{MgO}$ for basalts from Sites 448 and 451 (same symbols as in Fig. 24).

even more pronounced "decoupling" of LFS from HFS elements. The abundances of HFS elements in these rocks are similar to those in the KPR arc tholeiites. However, the LFS elements (notably $\mathrm{Ba}$ and Sr, Figs. 37 and 38) are strongly enriched relative to the PKR arc tholeiites. These clasts from the WMR are therefore not typical island-arc tholeiites but have affinities with the calc-alkaline magma series.

Recent lavas from the active Mariana arc (MA) are dominantly basalts and basaltic andesites, petrographically similar to those from the WMR (Dixon and Batiza, 1979). Characterized by only moderate ironenrichment and relatively $\mathrm{Al}_{2} \mathrm{O}_{3}$ - and $\mathrm{CaO}$-rich, these magmas are similar to (but not typical of) continental calc-alkaline magma series such as Japan or the Cascades. Isotope data suggest a mantle origin for these high-alumina basalts with negligible input from the sub-

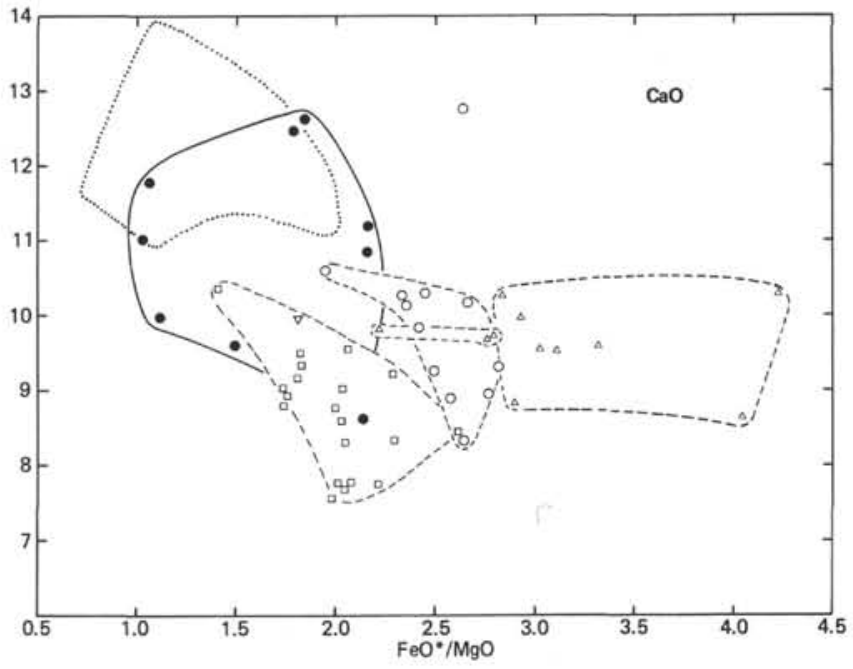

Figure 29. Plot of $\mathrm{CaO}(\%)$ versus $\mathrm{FeO} * / \mathrm{MgO}$ for basalts from Sites 448 and 451 (same symbols as in Fig. 24).

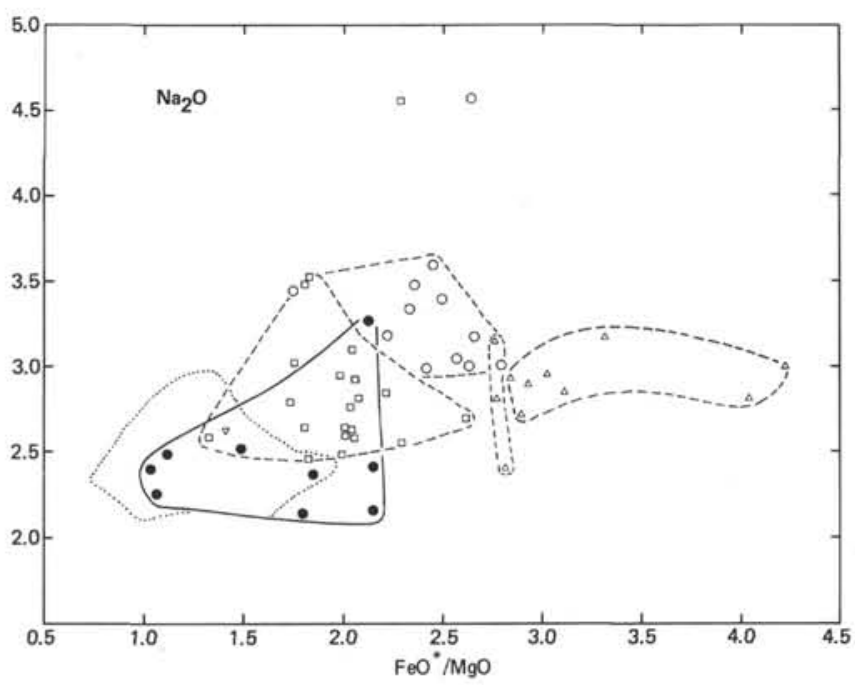

Figure 30. Plot of $\mathrm{Na}_{2} \mathrm{O}(\%)$ versus $\mathrm{FeO} * / \mathrm{MgO}$ for basalts from Sites 448 and 451 (same symbols as in Fig. 24).

ducted slab. Low abundances of HFS elements (similar to the WMR and PKR basalts) again characterize the recent Mariana lavas. LFS elements vary widely but are, on the average, considerably more enriched than the WMR basalts.

The abundances of a typical HFS element (Zr) and an LFS element $(\mathrm{Ba})$ along with the silica mode for available analyses of igneous rocks from the PKR, WMR, and Mariana arc (MA) are compared in Figure 41. The silica mode for all three island arcs is basaltic, slightly higher in the Mariana arc $(52 \%)$ than the WMR $(48 \%)$ or KPR $(49 \%)$. Andesites are more abundant in the MA, with $\mathrm{SiO}_{2}$ contents up to $60 \%$. A slight difference in the range of $\mathrm{Zr}$ contents is observed at each arc. The PKR arc tholeiites have a $\mathrm{Zr}$ mode of 40 to 60 ppm. The "LFS-enriched" island-arc volcanics from the WMR have slightly low $\mathrm{Zr}$ contents, with a mode 


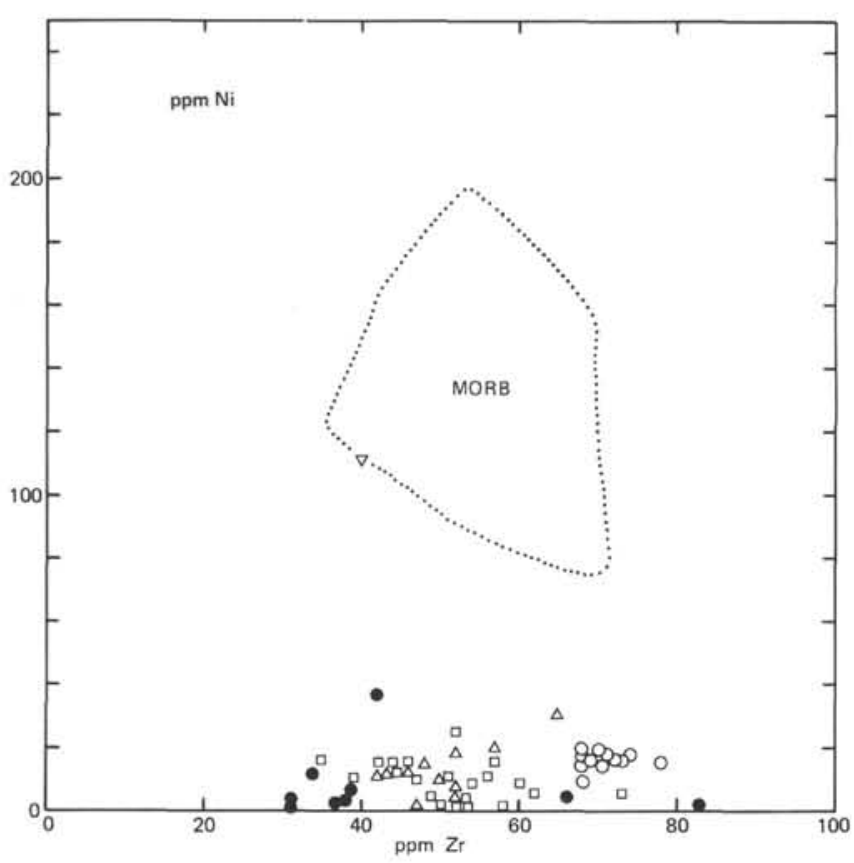

Figure 31. Plot of $\mathrm{Ni}(\mathrm{ppm})$ versus $\mathrm{Zr}$ for basalts from Sites 448 and 451 (same symbols as in Fig. 24).

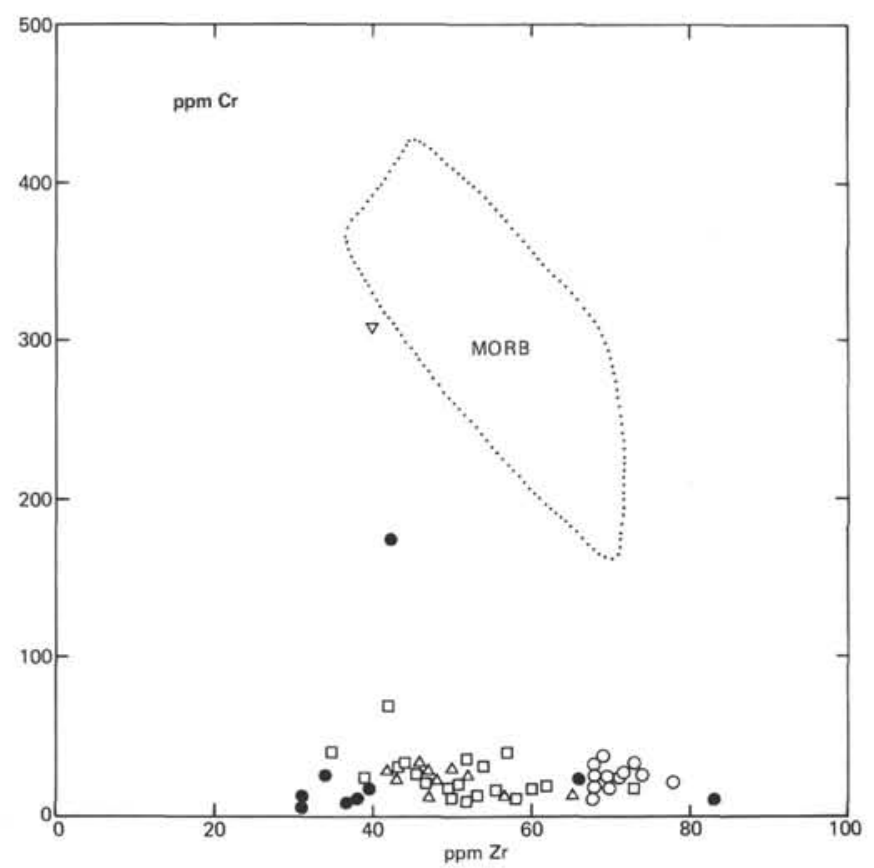

Figure 32. Plot of $\mathrm{Cr}(\mathrm{ppm})$ versus $\mathrm{Zr}$ for basalts from Sites 448 and 451 (same symbols as in Fig. 24).

around $35 \mathrm{ppm}$. Mariana arc volcanics have a relatively wide range of $\mathrm{Zr}$ contents (40-110 ppm) with a slightly higher mode $\sim 80 \mathrm{ppm}$, probably the result of a greater proportion of evolved rocks (andesites). The range in $\mathrm{Ba}$ contents of the volcanics at each arc, however, varies considerably. Whereas all the PKR arc tholeiites fall in

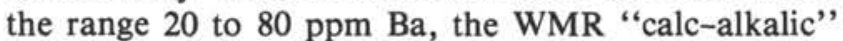
volcanics contain 90 to $180 \mathrm{ppm} \mathrm{Ba}$. The Mariana arc

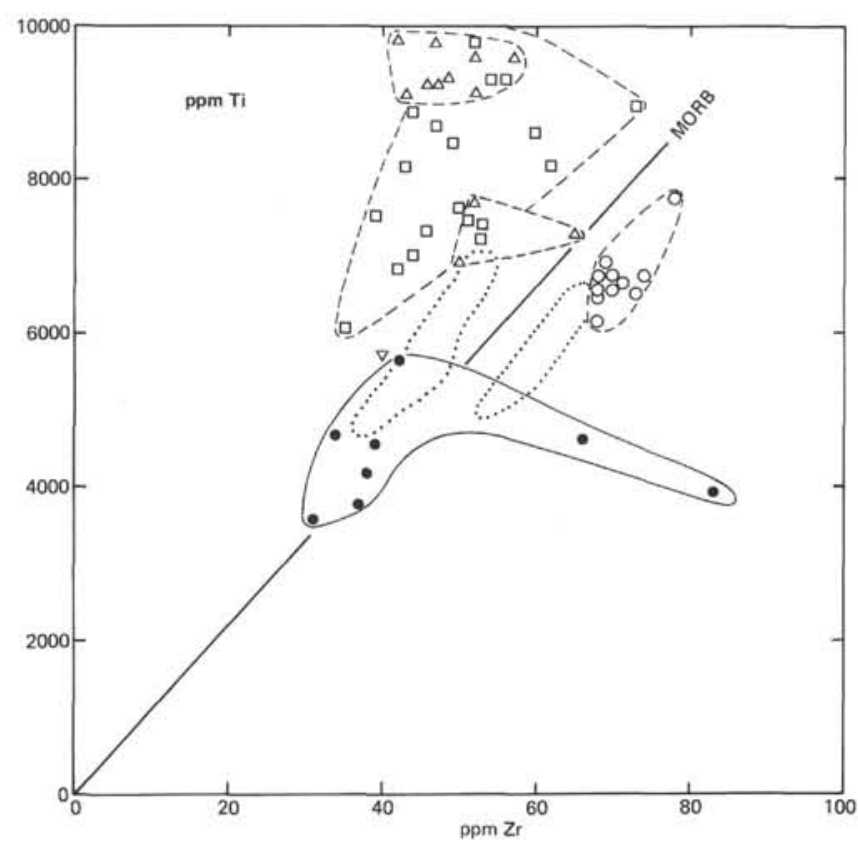

Figure 33. Plot of $\mathrm{Ti}(\mathrm{ppm})$ versus $\mathrm{Zr}$ for basalts from Sites 448 and 451. (Symbols are the same as those in Fig. 24. Most N-MORB have $\mathrm{Ti} / \mathrm{Zr}$ ratios $\sim 110$.)

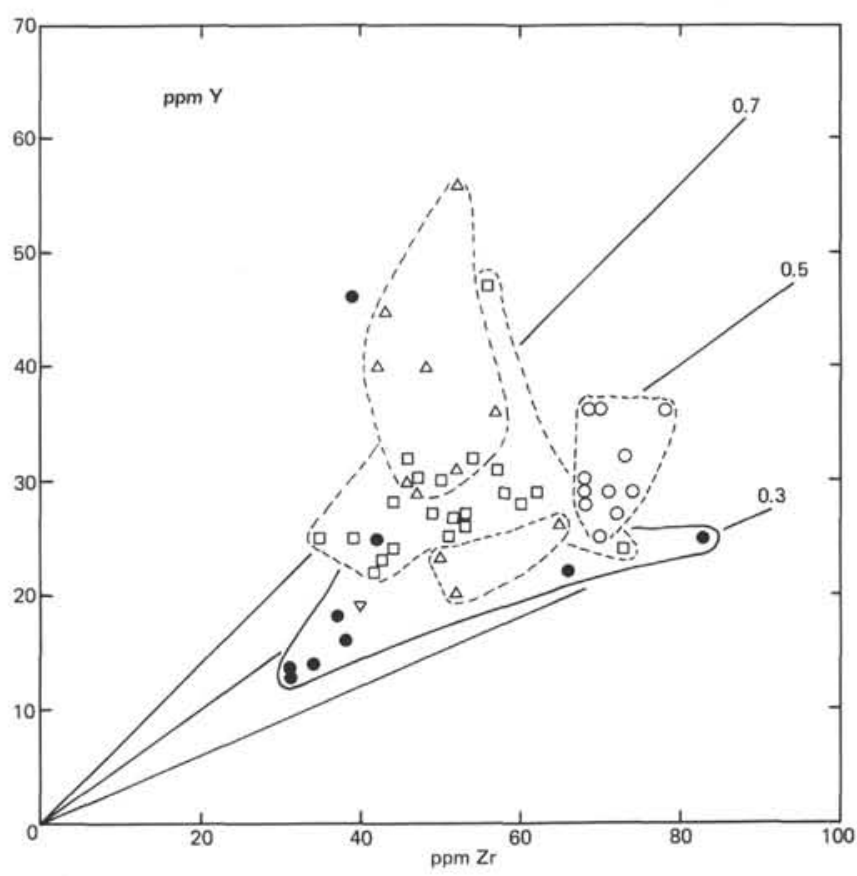

Figure 34. Plot of $\mathrm{Y}$ (ppm) versus $\mathrm{Zr}$ for basalts from Sites 448 and 451. (Symbols are the same as those in Fig. 24. Most N-MORB have $\mathrm{Y} / \mathrm{Zr}$ ratios $\sim 0.5$.)

lavas are characterized by $\mathrm{Ba}$ contents that range widely from 80 to over $600 \mathrm{ppm}$. However, the majority of basalts fall in the range 150 to $350 \mathrm{ppm} \mathrm{Ba}$. The $\mathrm{Ba}$ range (and that of other LFS elements such as $\mathrm{Th}, \mathrm{Pb}$, $\mathrm{Sr}$, and $\mathrm{Rb}$ ) is clearly greater in the recent volcanics, and the volcanic products of the active MA in general are 


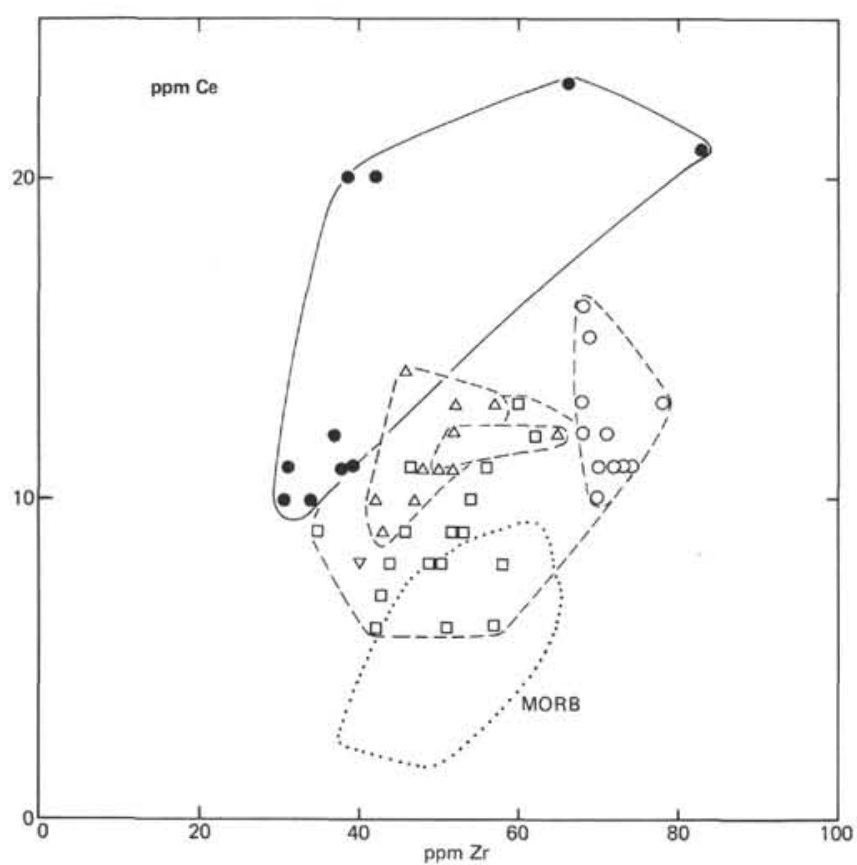

Figure 35. Plot of $\mathrm{Ce}(\mathrm{ppm})$ versus $\mathrm{Zr}$ for basalts from Sites 448 and 451 (same symbols as in Fig. 24).

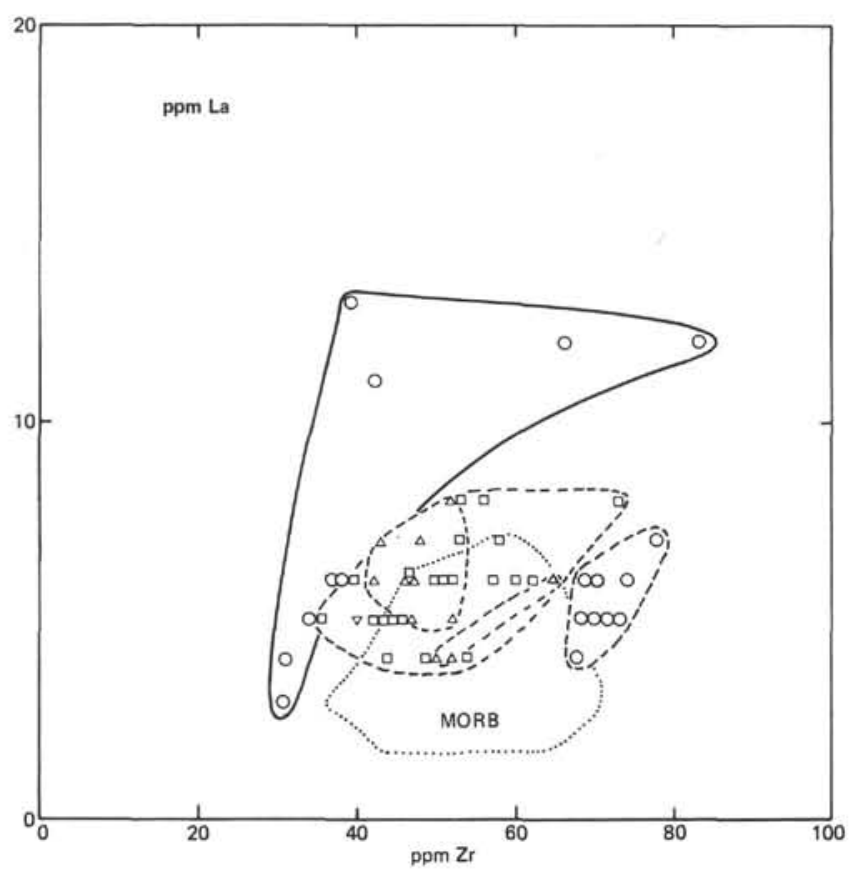

Figure 36. Plot of $\mathrm{La}(\mathrm{ppm})$ versus $\mathrm{Zr}$ for basalts from Sites 448 and 451 (same symbols as in Fig. 24).

characterized by higher LFS/HFS ratios than those from the remnant WMR. Thus remnant arcs preserved in the Philippine Sea were rifted from the active arc by two phases of marginal-basin spreading (which formed the Parece Vela Basin and the Mariana Trough, respectively). Presumably rifting occurs close to the volcanic line where the crust would be hotter and weaker, although it is not clear what proportion of the original

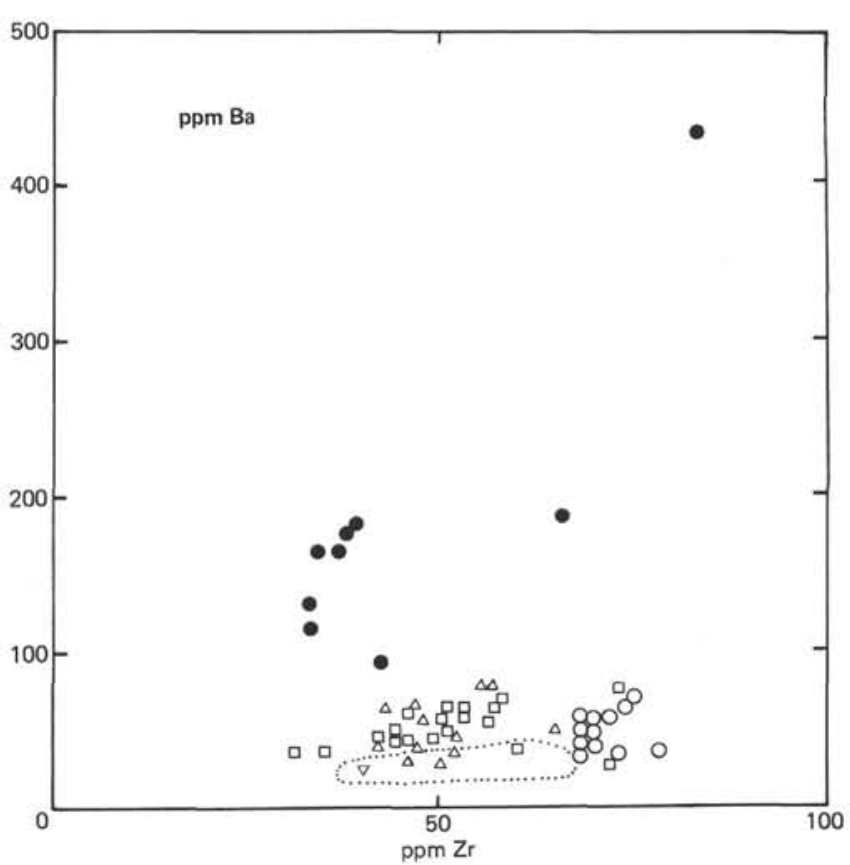

Figure 37. Plot of $\mathrm{Ba}(\mathrm{ppm})$ versus $\mathrm{Zr}$ for basalts from Sites 448 and 451 (same symbols as in Fig. 24).

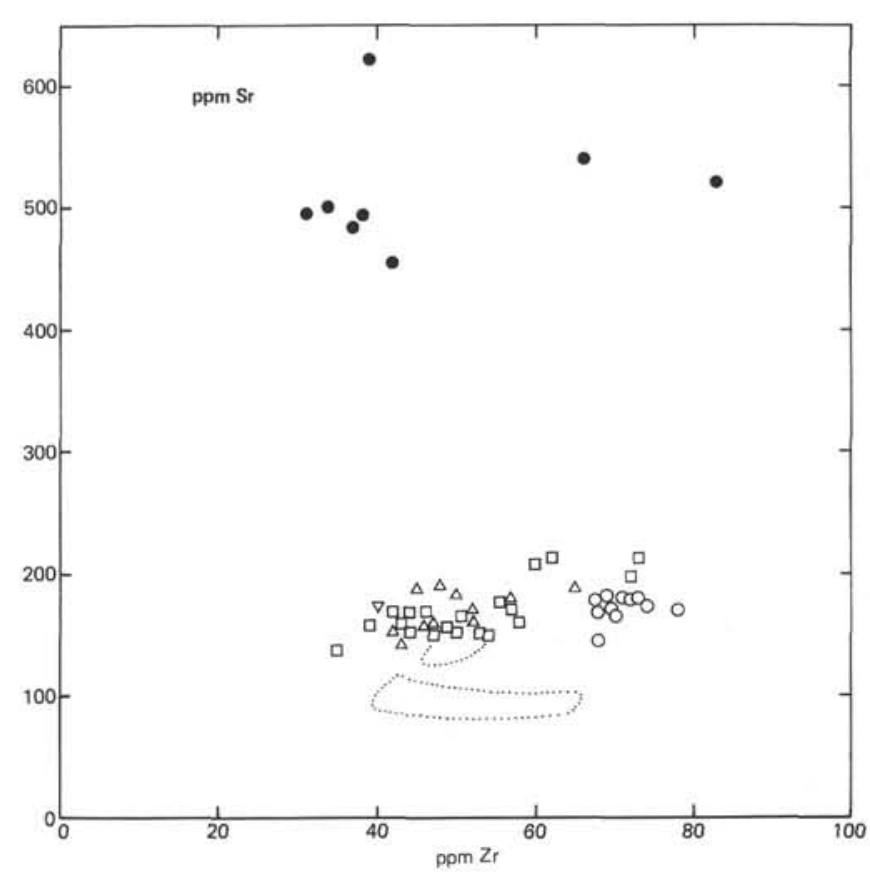

Figure 38. Plot of $\mathrm{Sr}(\mathrm{ppm})$ versus $\mathrm{Zr}$ for basalts from Sites 448 and 451 (same symbols as in Fig. 24).

arcs, if any, remains coupled to the trench. Sampling the PKR and WMR could be regarded as monitoring the evolution of essentially one single arc, which would have grown in place of the active Mariana arc if marginal basin spreading had not taken place. The amount of geochemical "evolution" recorded in the volcanic pile at each arc, however, would depend on where the arc rifted. As an extreme example, if the en- 


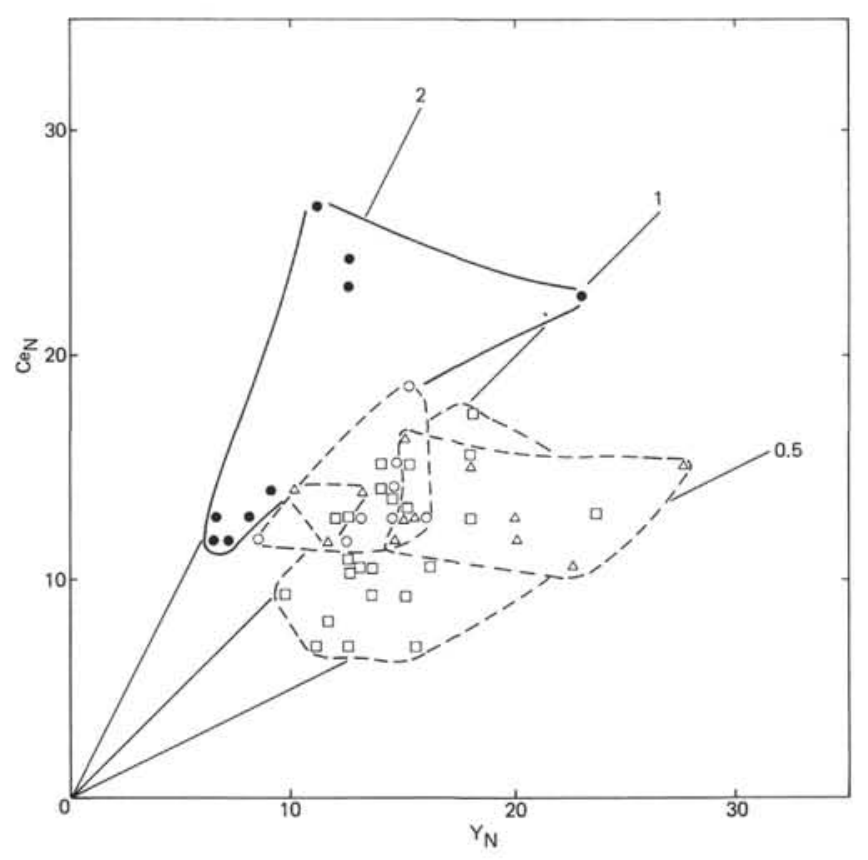

Figure 39. Plot of $C e_{N}$ versus $Y_{N}$ for basalts from Sites 448 and 451 . (Symbols are the same as those in Fig. 24. Normalizing values for chondrites are taken from Nakamura [1974].)

tire arc were removed from the subduction zone during marginal-basin spreading, then the range of magmas found in a complete section of the new frontal arc would be more limited than, say, if rifting had taken place along the volcanic line. In the latter case an early formed "root zone" might be expected, overlain by later, more calc-alkaline magmas. Boynton et al. (1979) suggest that such an island-arc tholeiite "root zone" exists beneath the calc-alkalic province of the Lesser Antilles arc.

Returning to the chemical differences between the two remnant arcs in the Philippine Sea, it is possible that the PKR and the WMR reached similar stages of "maturity" (i.e., an LFS-enriched "calc-alkaline" stage), but erosion of the older PKR has removed material to expose an early island arc-tholeiite "root zone." This explanation seems unsatisfactory, as the dikes and sills found deep in the section from the PKR are island-arc tholeiites with no calc-alkaline affinities. Alternatively, arc sundering and marginal-basin spreading might have been initiated earlier in the Parece Vela Basin (after the formation of PKR), characterized by typical island-arc tholeiite magmas; volcanism at the remnant WMR, and, to an even greater extent, on the active MA might have shifted toward magmas with increasingly marked calc-alkaline affinities (i.e., becoming richer in $\mathrm{Al}_{2} \mathrm{O}_{3}$ and $\mathrm{CaO}$, with a less pronounced trend toward iron enrichment and increased LFS/HFS ratios).

Transverse chemical variation across mature island arcs, such as Japan (e.g., Kuno, 1968), or at continental margins is well documented. Time-dependent chemical variation, as apparently seen in the South Philippine Sea, however, is less well understood. Comparing the older (Eocene) calc-alkaline Lesser Antilles arc with the younger ( 8 m.y.) tholeiitic South Sandwich arc, Baker (1968) suggested that after early arc building, magmas change in composition from tholeiitic to calc-alkaline as the arc matures. Jakeš and Gill (1970) and Jakeš and White (1972) incorporated these observations and developed a generalized model of island-arc evolution, combining both temporal and spatial variations in magma composition. The potentially large number of variables involved in island-arc magma genesis prompted Arculus and Johnson (1978) to criticize "generalization" at island arcs and to advocate the "uniqueness" of each subduction system. In particular, they revoke evidence for temporal variation at several island-arc systems, including the Lesser Antilles, Fiji, and New Guinea arcs. Nevertheless, chemical variation in the South Philippine remnant- and active-arc systems appear to be time-dependent, provided that Karig's (1972) model for arc sundering and marginal-basin spreading remains valid (i.e., that at some stage during the growth of the island arc, the arc was rifted by a phase of marginal-basin spreading, thus preventing the PalauKyushu Ridge from evolving beyond a tholeiitic phase).

Modern opinions on calc-alkaline magma genesis hold that these magmas fractionate from a parental LFS-enriched high-alumina basalt melted from a mantle metasomatized by LFS-rich fluid driven off the slab (e.g., Hawkesworth et al., 1977; Saunders et al., in press). The genesis of island-arc tholeiitic magmas remains controversial (see the proceeding section) but could be derived from a mantle source that is considerably less metasomatized than is the source for calc-alkaline magmas or possibly by direct remelting of the downgoing slab. However, the WMR "calcalkalic" basalts appear to be similar to recent Mariana arc lavas except for generally lower LFS/HFS ratios. Although there are many possible reasons for this difference in LFS content, during magma generation it is thought that both HFS and LFS elements are extracted from the overlying mantle wedge. Subsequent metasomatism by LFS-rich fluids increases the LFS/HFS element ratio of the now more-refractory mantle wedge. Further magma extraction from this source might result in liquids with higher LFS/HFS element ratios. And the change in LFS/HFS ratios might be further enhanced by the greater fluid input (hence greater LFS replenishment) required to lower the peridotite solidus sufficiently to melt the now more-refractory mantle wedge. If the overlying mantle wedge remains coupled with the subduction zone for both the WMR and active MA phases of arc volcanism, then the difference in LFS content might be explained by the continued replenishment of these elements derived from the subducted slab.

\section{A Speculation on the Genesis of the Philippine Sea}

Uyeda and Kanamori (1979) have defined two end members characterizing subduction boundaries found at plate margins. "Chilean subduction"' is characterized by a shallow trench, a shallow dipping Benioff zone, an 


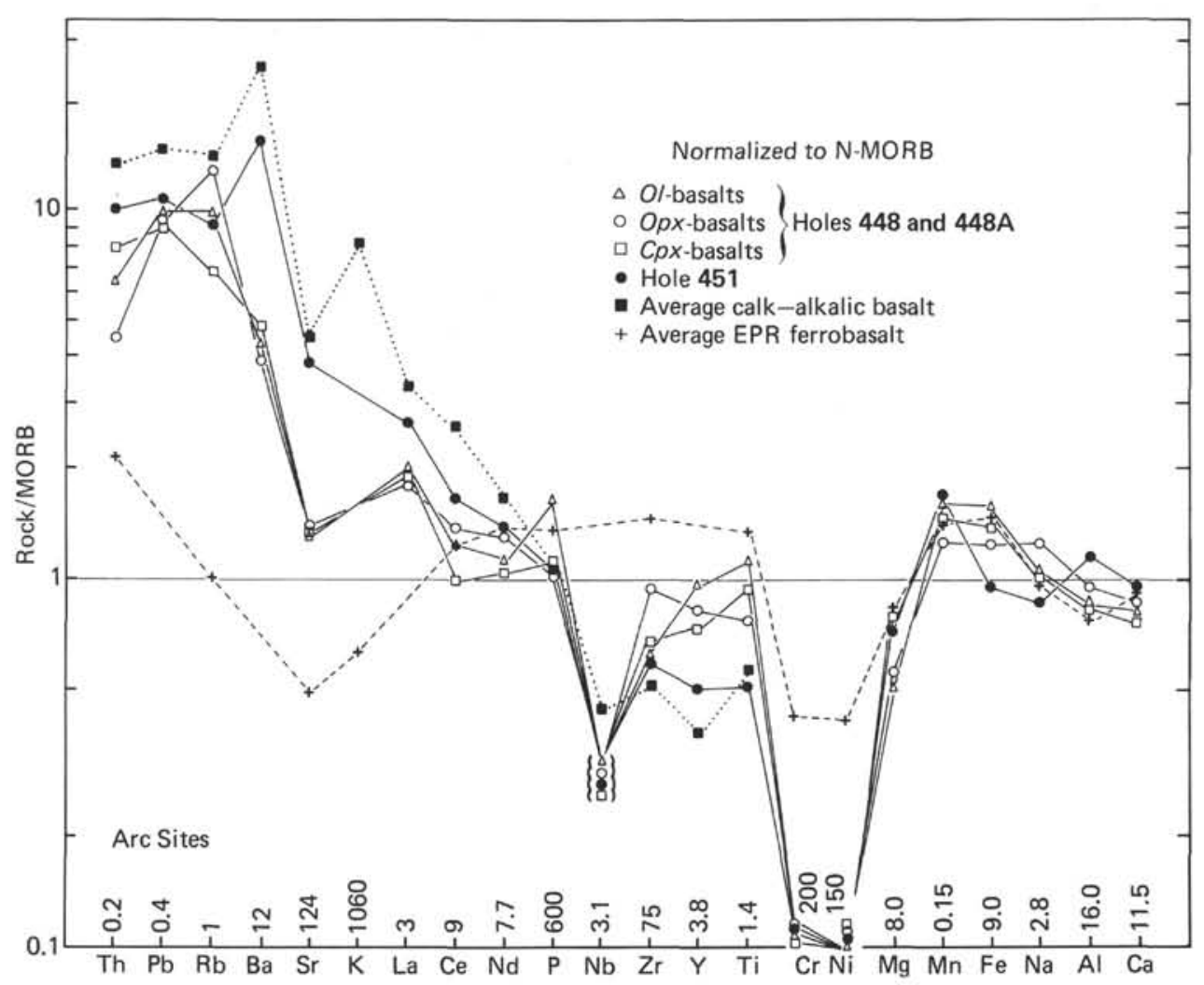

Figure 40. Representative basalt analyses from Holes 448, 448A, and 451 normalized to N-MORB. (Average compositions of the three major petrochemical groups from the Palau-Kyushu Ridge and of the basalts from the West Mariana Ridge are taken from Table 3. An average calc-alkalic basalt from Japan [Aramaki and Ui, in press] and a ferrobasalt from the East Pacific Rise [EPR, Mattey and Muir, in press] are plotted for comparison. The normalizing values [taken from Sun et al., 1979 and Wood et al., 1979a] are for a typical Mid-Atlantic Ridge N-MORB and are given at the bottom of the figure. The elements Th to Ti are arranged in an approximately increasing order of distribution coefficients for a mantle-melt system having a liquid in equilibrium with olivine \pm orthopyroxene \pm clinopyroxene.)

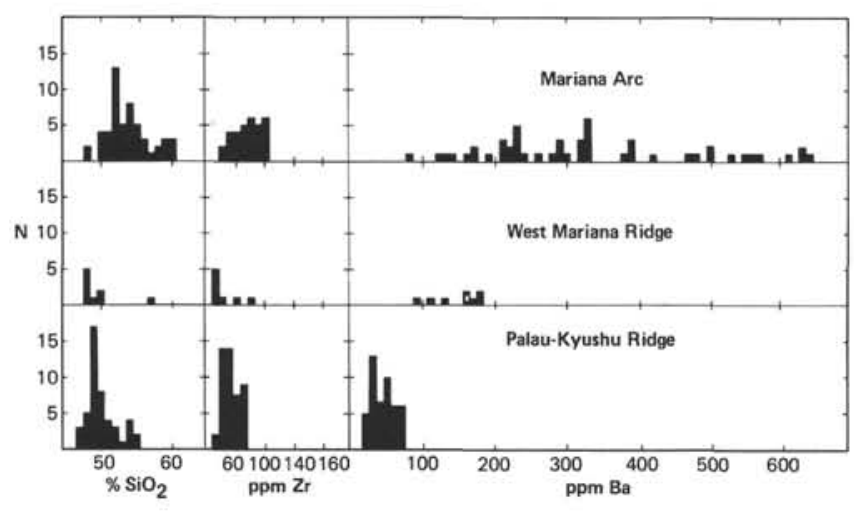

Figure 41. Histograms of silica content and the abundances of $\mathrm{Zr}$ (an HFS element) and $\mathrm{Ba}$ (an LFS element) in rocks from the PalauKyushu (island-arc tholeiites) and West Mariana ridges (calc-alkalic basalts) compared with available data from the active Mariana arc (Dixon and Batiza, 1979; Stern, 1979; P. Freyer, personal communication, 1980).

accretionary sedimentary prism, uplift and compression of the continental margin, and a high degree of coupling between the upper and lower plates. "Mariana-type subduction" is characterized by a deep trench, a steep or vertical Benioff zone, a barren trench wall, marginal- basin formation, and a low degree of coupling between the two plates. Chilean subduction is interpreted as forward continental motion overriding the oceanic lithosphere, whereas the oceanic lithosphere is thought to sink spontaneously into the mantle at a Mariana-type boundary. The Mariana-type boundary is essentially a tensional feature.

Kanamori $(1971,1977)$ had initially linked the two modes of subduction in a single "evolutionary" process. In this process, subduction begins as low-angle thrusting (e.g., the Alaska Trench), and as the dense lithospheric slab penetrates the mantle, increased intraplate tension within the downgoing slab reduces coupling between the two plates (e.g., in the Kurile and Japan arcs). It is possible that extreme decoupling may eventually result in the oceanic plate beginning to sink before it reaches the trench. Kanamori (1977) suggested that the formation of marginal basins was a result of the trench "retreating" from the landward plate.

An alternative to this "evolutionary"' model was proposed in 1979 by Uyeda and Kanamori: at the Marianatype boundary, the downgoing slab is anchored to the mantle. Thus the position of the trench, relative to the mantle, is fixed, because it would be difficult for the slab to move perpendicularly to the strike of the trench. 
The motion of the landward plate (i.e., the Eurasian plate in the Philippine Sea area) then controls the opening of marginal basins, and tensional tectonics in the back-arc region are not a direct result of subduction.

Various attempts to determine the "absolute" motions of plates relative to the mantle (e.g., Fitch, 1972; Minister et al., 1974) indicate westward motion of the Philippine Sea plate and of other landward plates at subduction boundaries. It is therefore more likely that marginal basins will develop behind anchored "Mariana-type subduction" boundaries with steep westwarddipping Benioff zones (as is clearly the case in the Mariana, Tonga-Kermadec, or the South Sandwich arcs).

In the light of Leg 59 results, the "anchored-slab" model has several attractions over the evolutionary, or "retreating-trench," model. In the anchored-slab model, the same mantle wedge would remain essentially coupled with the Benioff zone for the two phases of marginal-basin spreading observed in the Philippine Sea. (For the trench to retreat during marginal-basin spreading, as in the evolutionary model, it would be necessary for mantle material to flow back around the descending slab as it sinks obliquely through the mantle.) The superjacent mantle wedge, enriched in LFS elements during the first phase of arc building, would probably be replenished with material from elsewhere that is poor in LFS-elements.

The spatial geochemistry of the Philippine Sea island arcs may be interpreted in terms of the anchored-slab model; Figure 42, a cartoon illustrating a possible history of the Philippine Sea, is based on these principles. The Palau-Kyushu Ridge, built by island-arc tholeiite volcanism, would be associated with a trenchsubduction zone system in essentially the same position (relative to the upper mantle) as the present day Mariana Trench (Stage A, Fig. 42). The Parece Vela Basin would be formed by rifting along the PKR volcanic line as a response to westerly movement of the West Philippine Basin (Stage B, Fig. 42). During marginal-basin formation, the mantle wedge above the descending Pacific plate may be partly replenished by mantle material from the low-velocity zone. However, the bulk of the mantle wedge remains coupled with the subduction zone and is likely to be replenished with LFS elements derived from the dehydration of the Pacific plate. Renewed arc building on the edge of the Parece Vela Basin would be derived from a relatively LFSenriched (or HFS-depleted) source compared to the PKR volcanics (Stage C, Fig. 42). The West Mariana arc, built by more calc-alkalic volcanism, then sunders (in a similar fashion to the PKR during Stage B) to form the Mariana Trough (Stage D, Fig. 42). Meanwhile, the mantle source for the present-day Mariana arc is now likely to be highly variable but is probably characterized by relatively high LFS/HFS element ratios, owing to the continued replenishment of LFS elements from the descending slab and depletion of HFS elements during the continuous extraction of magma. Thus modern Mariana arc calc-alkaline volcanics display a very wide range of LFS/HFS element ratios (see Table 23) that are

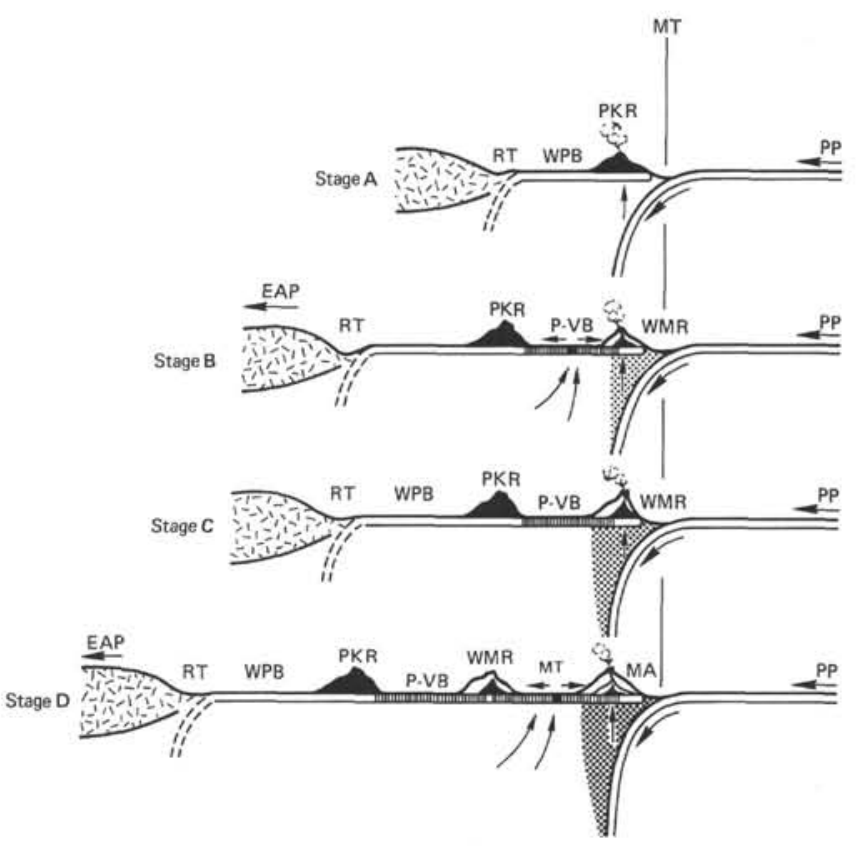

Figure 42. Cartoon illustrating a possible history of the Philippine Sea. (See text for full explanation. The position of the Mariana Trench [MT] is fixed, relative to the mantle, and the superjacent mantle wedge remains coupled to the descending slab from the time of formation of the Palau-Kyushu Ridge [PKR] to the present day. The stippled area indicates the region affected by the removal of HFS elements during magma extraction and replenishment of LFS elements by LFS-rich fluids driven off the descending slab. RT-Ryukyu Trench; WPB-West Philippine Basin; P-VBParece-Vela Basin; WMR - West Mariana Ridge; MT [small capital letters in Stage D]-Mariana Trough: MA-Mariana Arc; $\mathrm{PP}-$ Pacific plate; EAP-Eurasian plate.)

generally higher than those of the WMR ridge volcanics. The initial spreading of the marginal basins might also be expected to sample LFS-enriched mantle material. It is interesting to note that marginal-basin basalts with calc-alkaline affinities have been drilled in the Mariana Trough during Leg 60 (Tarney et al., in press) and dredged from the Scotia Sea (Saunders et al., in press).

\section{CONCLUSIONS}

1) The basalts drilled in the West Philippine (Site 447) and Parece Vela (Sites 449 and 450) marginal basins are similar to typical N-MORB.

2) Site 447 basalts have undergone a complex magmatic history. At least two separate magma chambers and feeder systems, tapping two chemically distinct primary magma sources, must have existed simultaneously to account for the observed chemical variations in Hole 447A. Each magma chamber was also periodically replenished with a porphyritic primitive magma followed by mixing and a phase of fractional crystallization prior to eruption.

3) The holes drilled on the Palau-Kyushu Ridge (at Site 448) reveal a complex sequence of pillow lavas, flows, sills, and dikes interbedded with volcanic breccia and tuffs. The basalts and basaltic andesites from this section are typical island-arc tholeiites characterized by 
high $\mathrm{FeO} / \mathrm{MgO}$ ratios, low abundances of $\mathrm{Cr}, \mathrm{Ni}$, and HFS elements such as $\mathrm{Zr}, \mathrm{Nb}$, or $\mathrm{Y}$, and enriched (relative to N-MORB) in LFS elements such as Th, $\mathrm{Pb}$, $\mathrm{Rb}, \mathrm{Sr}$, and $\mathrm{Ba} . \mathrm{Ce}_{\mathrm{N}} / \mathrm{Y}_{\mathrm{N}}$ ratios of these rocks are similar to MORB.

4) Many geochemical features of the Site 448 islandarc tholeiites are not wholly compatible with derivation from a mantle source followed by extensive fractional crystallization. An alternative model, in which these arc tholeiites are generated as remelts of subducted oceanic (basaltic) crust, might be geochemically, if not thermodynamically, more realistic.

5) Igneous clasts from the breccias drilled on the West Mariana Ridge (Site 451), which have affinities with the calc-alkaline magma series, are petrographically and geochemically different from the Site 448 (PKR) island-arc tholeiites. The WMR basalts and rare andesites from this site are characterized by higher contents of $\mathrm{Al}_{2} \mathrm{O}_{3}$, higher $\mathrm{Ce}_{\mathrm{N}} / \mathrm{Y}_{\mathrm{N}}$ ratios $(\sim 2)$, and are more enriched in LFS elements relative to HFS elements.

\section{ACKNOWLEDGMENTS}

We are grateful to Dr. G. L. Hendry for providing XRF facilities and to Nigel Donellan for help with data processing. D. P. Mattey is also grateful to Dr. J. V. Long for the use of the electron-microprobe facilities at the Department of Mineralogy and Petrology, Cambridge, and to Dr. P. Trelaur for assistance in operating these facilities. Financial support for this work was provided by the Natural Environment Research Council.

\section{REFERENCES}

Anderson, R. N., DeLong, S. E., and Schwarz, W. H., 1978. Thermal model for subduction with dehydration in the downgoing slab. $J$. Geol., 86:731-739.

Aramaki, S., and Ui, T., in press. Andesite volcanism in Japan, Kurile, Kamchatka, Izu, and Mariana Areas. In Thorpe, R. S. (Ed.), Orogenic Andesites: London (Wiley).

Arculus, R. J., and Johnson, R. W., 1978. Criticism of generalized models for the magmatic evolution of trench-arc systems. Earth Planet. Sci. Lett., 39:118-126.

Armstrong, R. L., 1968. A model for the evolution of strontium and isotopes in a dynamic earth. Rev. Geophysics, 6:175-199.

1971. Isotopic and chemical constraints on models of magma genesis in volcanic arcs. Earth Planet. Sci. Lett., 12:137142.

Armstrong, R. L., and Cooper, J. A., 1971. Lead isotopes in island arcs. Bull. Volcanol., 35:27-63.

Arth, J. G., and Hanson, G. N., 1975. Geochemistry and origin of the early Precambrian crust of north-eastern Minnesota. Geochim. Cosmochim. Acta, 39:325-362.

Aumento, F., 1964. The Mid-Atlantic Ridge near $45^{\circ} \mathrm{N}$, II. Basalts from the Area of Confederation Peak. Can. J. Earth Sci., 5:1.

Baker, P. E., 1968. Comparative volcanology and petrology of Atlantic island arcs. Bull. Volcanol., 32:189-206.

Barker, P. F., 1970. A spreading centre in the east Scotia Sea. Earth Planet. Sci. Lett., 15:123-132.

Ben-Avraham, Z., Bown, C., and Segawa, J., 1972. An extinct spreading center in the Philippine Sea. Nature, 240:435-455.

Best, M. G., 1975. Migration of hydrous fluids in the upper mantle and potassium variation in calc-alkalic rocks. Geology, 3:492432.

Blanchard, D. P., Rhodes, J. M., Dungan, M. A., et al., 1976. The chemistry and petrology of basalts from Leg 37 of DSDP. $J$. Geophys. Res., 81:4231.

Bonatti, E., Zerbi, M., Kay, R., et al., 1976. Metalliferous deposits from the Appennine ophiolites: Mesozoic equivalents of modern deposits from oceanic spreading centers. Bull. Geol. Soc. Am., 87:83-98.

Boynton, C. H., Westbrook, G. K., Bott, M. H. P., et al., 1979. A seismic refraction investigation of crustal structure beneath the Lesser Antilles Arc. Geophys. J. Roy. Astron. Soc., 58:371-393.

Bryan, W. B., 1972. Mineralogical studies of submarine basalts. Carnegie Inst. Wash. Yr. Book, 71:396-403.

Bryan, W. B., and Moore, J. G., 1977. Compositional variation of young basalts in the Mid-Atlantic rift valley near Latitude $36^{\circ} 49^{\prime}$ N. Bull. Geol. Soc. Am., 88:556-570.

Buma, G., Frey, F. A., and Wones, D. R., 1971. New England granites: trace element evidence regarding their origin and differentiation. Contrib. Mineral. Petrol., 31:300-320.

Cann, J. R., 1970. Rb, Sr, Y, Zr, and $\mathrm{Nb}$ in some ocean floor basaltic rocks. Earth Planet. Sci. Lett., 10:7-11.

Cawthorne, R. G., Ford, C. E., Biggar, G. M., et al., 1973. Determination of the liquid composition in experimental samples: discrepancies between microprobe and other methods. Earth Planet. Sci. Lett., 21:1-5.

Dasch, E. J., Hedge, C. E., and Dymond, J., 1973. Effect of seawater interaction on strontium isotope compositions of deep sea basalts. Earth Planet. Sci. Lett., 19:177-183.

Dick, H. J. B., 1976. Spinel in Fracture Zone "B" and median valley basalts, FAMOUS area, Mid-Atlantic Ridge. EOS, 57:341.

Dietrich, V., Emmerman, R., Oberhansli, R., et al., 1978. Geochemistry of basaltic and gabbroic rocks from the West Mariana Basin and Mariana Trench. Earth Planet. Sci. Lett., 39:127-144.

Dixon, T. H., and Batiza, R., 1979. Petrology and chemistry of recent lavas in the northern Marianas: implications for the origin of island arc basalts. Contrib. Mineral. Petrol., 70:167-181.

Donaldson, C. H., and Brown, R. W., 1977. Refractory megacrysts and magnesium rich melt inclusions with spinel in oceanic tholeiites: indicators of margin mixing and parental magma composition. Earth Planet. Sci. Lett., 37:81-89.

Donaldson, C. H., Brown, R. W., and Reid, A. M., 1976. Petrology and chemistry of basalts from the Nazca Plate. 1. Petrography and mineral chemistry. In Hart, S. R., Yeats, R. S., et al., Init. Repts. DSDP, 34: Washington (U.S. Govt. Printing Office), 227-238.

Donelly, T. W., Rodgers, J. J. W., Puskar, P., et al., 1971. Chemical evolution of the igneous rocks from the eastern West Indies: an investigation of $\mathrm{Th}, \mathrm{U}$, and $\mathrm{K}$ distributions and lead and strontium isotopic ratios. Geol. Soc. Am. Mem., 130:181-224.

Drake, M. J., 1976. Plagioclase-melt equilibria. Geochim. Cosmochim. Acta, 40:457-466.

Drake, M. J., and Weill, D. F., 1975. Partition of Sr, Ba, Ca, Y, $\mathrm{Eu}^{2+}, \mathrm{Eu}^{3+}$, and other REE between plagioclase feldspar and magmatic liquid: an experimental study. Geochim. Cosmochim. Acta, 39:689-712.

Dungan, M. A., and Rhodes, J. M., 1978. Residual glasses and melt inclusions in basalts from DSDP Legs 45 and 46: evidence of magma mixing. Contrib. Mineral. Petrol., 87:417-431.

Erlank, A. J., and Kable, E. J. D., 1976. The significance of incompatible elements in mid-Atlantic Ridge basalts from $45^{\circ} \mathrm{N}$ with particular reference to $\mathrm{Zr} / \mathrm{Nb}$. Contrib. Mineral. Petrol., 54:281291.

Ewart, A., Bryan, W. B., and Gill, J. B., 1973. Mineralogy and geochemistry of the younger volcanic islands of Tonga, S.W. Pacific. J. Petrol., 14:429-436.

Ewart, A., and Stipp, J. J., 1968. Petrogenesis of the volcanic rocks of the central North Island, New Zealand, as indicated by a study of ${ }^{87} \mathrm{Sr} /{ }^{86} \mathrm{Sr}$ ratios, and $\mathrm{Sr}, \mathrm{Rb}, \mathrm{K}, \mathrm{U}$, and $\mathrm{Th}$ abundances. Geochim. Cosmochim. Acta, 32:699-736.

Fischer, A. G., Heezen, B. C., et al., 1971. Init. Repts. DSDP, 6: Washington (U.S. Govt. Printing Office).

Fitch, T., 1972. Plate convergence, transcurrent faults and internal deformation adjacent to southeast Asia and the Western Pacific. Bull. Seismol. Soc. Am., 60:565-591.

Fitton, J. G., 1971. The generation of magmas in island arcs. Earth Planet. Sci. Lett., 11:63-67.

Floyd, P. A., and Tarney, J., 1979. First order alteration chemistry of Leg 49 basement rocks. In Luyendyk, B. P., Cann, J. R., et al., Init. Repts. DSDP, 49: Washington (U.S. Govt. Printing Office), 693-708. 
Frey, F. A., Bryan, W. B., Thompson, G., 1974. Atlantic Ocean floor: geochemistry and petrology of basalts from Legs 2 and 3 of the DSDP. J. Geophys. Res., 81:5507-5527.

Gill, J. B. 1974. Role of underthrust oceanic crust in the genesis of a Fijian calc-alkaline suite. Contrib. Mineral. Petrol., 43:29-45.

Green, D. H., 1972. Magmatic activity as the major process in chemical evolution of the earth's crust and mantle. Tectonophysics, 13:47-51.

Hanson, G. N., 1977. Geochemical evolution of suboceanic mantle. J. Geol. Soc. London, 134:235-253.

Hart, R. A., 1970. Chemical exchange between seawater and deep ocean basalts. Earth Planet. Sci. Lett., 9:269-279.

Hart, S. R., 1969. K, Rb, Cs contents and K/Rb and K/Cs ratios of fresh and altered submarine basalts. Earth Planet. Sci. Lett., 6:295-303.

Hart, S. R., Erlank, A. J., and Kable, E. D. J., 1974. Sea floor basalt alteration: some chemical and $\mathrm{Sr}$ isotopic effects. Contrib. Mineral. Petrol., 44:219-230.

Hart, S. R., Glassley, W. E., and Karig, D. E., 1972. Basalts and seafloor spreading behind the Mariana Island Arc. Earth Planet. Sci. Lett., 15:12-18.

Hawkesworth, C. J. O'Nions, R. K., and Arculus, R. J., 1979. Nd and $\mathrm{Sr}$ isotope geochemistry of island arc volcanics, Grenada, Lesser Antilles, Earth Planet. Sci. Lett., 45:237-248.

Hawkesworth, C. J., O'Nions, R. K., Pankhurst, R. J., et al., 1977. A geochemical study of island-arc and back-arc tholeiites from the Scotia Sea. Earth Planet. Sci. Lett., 36:253-269.

Hawkins, J. W., 1976. Petrology and geochemistry of basaltic rocks of the Lau Basin. Earth Planet. Sci. Lett., 28:283-297.

Hellman, P., and Green, T. H., 1979. The role of sphene as an accessory phase in the high pressure partial melting of hydrous mafic compositions. Earth Planet. Sci. Lett., 42:38-40.

Hilde, T. W. G., Uyeda, S., and Kroenke, L., 1977. Evolution of the Western Pacific and its margin. Tectonophysics, 38:145-165.

Hill, R., and Roeder, P., 1974. The crystallization of spinel from a basaltic liquid as a function of oxygen fugacity. J. Geol., 82:709-729.

Hoffert, M., Perseil, A., Kekimian, R., et al., 1978. Hydrothermal deposits sampled by diving saucer in transform fault "A" near $37^{\circ} \mathrm{N}$ on the Mid-Atlantic Ridge, FAMOUS Area. Oceanol. Acta, $1: 73-86$.

International Working Group on the IGCP Project "Ophiolites," 1977. Initial Report of the Geological Study of Oceanic Crust of the Philippine Sea Floor: Bolletino del Gruppo di Lavoro aulle Ofioliti Mediterranee (Vol. 2): Bologna, (Estratto da Ofioliti), 137-168.

Irvine, T. N., 1967. Chromian spinel as a petrogenetic indicator, Part 2: Petrologic applications. J. Earth Sci., 4:71-103.

Jakeš, P., and Gill, J., 1970. Rare earth elements and the island arc tholeiite series. Earth Planet. Sci. Lett., 9:17-28.

Jakeš, P., and White, A. J. R., 1972. Major and trace element abundances in volcanic rocks of orogenic areas. Bull. Geol. Soc. Am., $83: 29-40$

Kanamori, H., 1971. Great earthquakes at island arcs and the lithosphere. Tectonophysics, 12:187-198.

1977. Seismic and aseismic slip along subduction zones and their tectonic implications. In Talwani, M., and Pitmann, W. C. (Eds.), Island Arcs, Deep Sea Trenches, and Back Arc Basins: Washington (Am. Geophys. Union), pp. 62-174.

Karig, D. E., 1971. Origin and development of marginal basins in the Western Pacific. J. Geophys. Res., 76:2542-2561.

1972. Remnant arcs. Bull. Geol. Soc. Am., 83: 1057-1068.

1975. Basin genesis in the Philippine Sea. In Karig, D. E. Ingle, J. C., et al., Init. Repts. DSDP, 31: Washington (U.S. Govt. Printing Office), 857-879.

Karig, D. E., Anderson, R. N., and Bibee, L. D., 1978. Characteristics of back-arc spreading in the Mariana Trough. J. Geophys. Res., 83:1213-1226.

Karig, D. E., and Glassley, W. E., 1970. Dacite and related sediment from the West Mariana Ridge, Philippine Sea. Bull. Geol. Soc. Am., 81:2143-2146.

Karig, D. E., Ingle, J. C., Jr., et al., 1975. Site 296. In Karig, D. E., Ingle, J. C., Jr., et al., Init. Repts. DSDP, 31: Washington (U.S. Govt. Printing Office), 191-296.
Kuno, H., 1968. Origin of andesite and its bearing on the island-arc structure. Bull. Volcanol., 32:141-176.

Leg 60 Scientific Party, 1979. Near the Philippines, Leg 60 ends in Guam. Geotimes, 23-10:19-22.

Lofgroen, G., Donaldson, C. H., Williams, R. J., et al., 1974. Experimentally produced textures and mineral chemistry of Apollo 15 quartz-normative basalts. Geochim. Cosmochim. Acta, Suppl. 5 , $1: 549-567$.

Louden, K. E., 1976. Magnetic anomalies in the West Philippine Basin. In Sutton, G. H., Manghnani, M. H., Moberly, R. (Eds.), The Geophysics of the Pacific Ocean Basin and its Margin: Geophys. Monograph. Ser. (Vol. 19): Washington (Am. Geophys. Union), 253-267.

MacLean, W. H., 1969. Liquidus-phase relationships in the FeS-FeO$\mathrm{Fe}_{3} \mathrm{O}_{4}-\mathrm{SiO}_{2}$ system and their application in geology. Econ. Geol., 64:865-884.

Magaritz, M., Whitford, D. J., and James, D. E., 1978. Oxygen isotopes and the origin of high ${ }^{87} \mathrm{Sr}^{86} \mathrm{Sr}$ andesites. Earth Planet. Sci. Lett., 40:220-230.

Marsh, N. G., Tarney, J., Saunders, A. D., et al., in press. Geochemistry of Shikoku Basin basalts recovered during Leg 58 of the International phase of Ocean Drilling. In Klein, G. deV., Kobayashi, K., et al., Init. Repts. DSDP, 58: Washington (U.S. Govt. Printing Office).

Masuda, Y., and Aoki, K-I., 1979. Trace-element variations in the volcanic rocks from the Nasu Zone, Northeast Japan. Earth Planet. Sci. Lett., 44:139-149.

Mattey, D. P., and Muir, I. D., in press. The geochemistry and mineralogy of basalts from the Galapagos spreading center, IPOD Leg 54. In Hekinian, R., Rosendahl, B., et al., Init. Repts. DSDP, 54: Washington (U.S. Govt. Printing Office).

McCarthy, T. S., and Kable, E. J. D., 1978. On the behavior of rareearth elements during partial melting of a granitic rock. Chem. Geol., 22:21-29.

Meijer, A., 1976. $\mathrm{Pb}$ and $\mathrm{Sr}$ isotopic data bearing on the origin of volcanic rocks from the Mariana island-arc system. Bull. Geol. Soc. Am., 87:1358-1369.

Melson, W. G., 1979. Regional variation and petrogenesis of basalt glasses from the FAMOUS area, Mid-Atlantic Ridge. J. Petrol., 20:293-325.

Melson, W. G., and Thompson, G., 1971. Petrology of a transform fault zone and adjacent ridge segments. Phil. Trans. Roy. Soc. London, A, 268:423.

Melson, W. G., Thompson, G., and van Andel, Tj. H., 1968. Volcanism and metamorphism in the Mid-Atlantic Ridge, $22^{\circ} \mathrm{N}$ latitude. J. Geophys. Res., 73:5925.

Minister, J. B., Jordan, T. H., Molnar, P., et al., 1974. Numerical modelling of instantaneous plate tectonics. Geophys. J. Roy. Astron. Soc., 36:541-576.

Miyashiro, A., Shido, F., and Ewing, M., 1970. Diversity and origin of abyssal tholeiites from the Mid-Atlantic Ridge near $24^{\circ}$ and $30^{\circ} \mathrm{N}$ latitude. Contrib. Mineral. Petrol., 23:38-52.

Muir, J. D., and Tilley, C. E., 1964. Basalts from the N. part of the rift zone of the Mid-Atlantic Ridge. J. Petrol., 5:409-434.

Natland, J., Rosendahl, B., Hekinian, R., et al., 1979. Galapagos hydrothermal mounds: stratigraphy and chemistry revealed by Deep Sea Drilling. Science, 204:613-616.

Nicholls, G. D., and Islam, M. R., 1971. Geochemical investigations of basalts and associated rocks from the ocean floor and their implications. Philos. Trans. R. Soc. London, 268A:469-486.

Nichols, I. A., 1974. Liquids in equilibrium with peridotitic mineral assemblages at high water pressures. Contrib. Mineral. Petrol., 45: 289-316.

Nichols, I. A., and Ringwood, A. E., 1973. Effect of water on olivine stability in tholeiites and the production of silica-saturated magmas in island arcs. J. Geol., 81:285-300.

Oversby, V. M., and Ewart, A., 1972. Lead isotopic compositions of Tonga-Kermadek volcanics and their petrogenetic significance. Contrib. Mineral. Petrol., 37:181-210.

Pearce, J. A., and Cann, J., 1973. Tectonic setting of basic volcanic rocks using trace element analyses. Earth Planet. Sci. Lett. 19:290-300. 
Pearce, J. A., and Norry, M. J., 1979. Petrogenetic implications of $\mathrm{Ti}, \mathrm{Zr}, \mathrm{Y}$, and $\mathrm{Nb}$ variations in volcanic rocks. Contrib. Mineral. Petrol., 69:33-47.

Philpotts, J. A., and Schnetzler, C. C., 1970. Phenocryst matrix partition coefficients for $\mathrm{K}, \mathrm{Rb}, \mathrm{Sr}$ and $\mathrm{Ba}$ with applications to anorthosite and basalt genesis. Geochim. Cosmochim. Acta, 34: 307-322.

Pritchard, R. G., Cann, J. R., and Wood, D. A., 1979. Low temperature alteration of ocean basalts, DSDP Leg 49. In Luyendyk, B. P., Cann, J. R., et al., Init. Repts. DSDP, 49: Washington (U.S. Govt. Printing Office), 709-714.

Pushkar, P., Steuber, A. M., Tomblin, J. F., et al., 1973. Strontium isotopic ratios in volcanic rocks from St. Vincent and St. Lucia, Lesser Antilles, J. Geophys. Res., 78:1279-1287.

Rhodes, J. M., Blanchard, D. P., Rodgers, K. V., et al., 1976. Petrology and chemistry of basalts from the Nazca Plate: Part 2-major and trace element chemistry. In Hart, S. R., Yeats, R. S., et al., Init. Repts. DSDP, 34: Washington (U.S. Govt. Printing Office), 239-244.

Ringwood, A. E., 1977. Petrogenesis in island arc systems. In Talwani, M., and Pitman, W., III (Eds.), Island Arcs, Deep Sea Trenches, and Back-arc Basins: Washington (Am. Geophys. Union), pp. 311-324.

Roeder, P. L., and Emslie, R. F., 1970. Olivine-liquid equilibrium. Contrib. Mineral. Petrol., 29:275-289.

Saunders, A. D., and Tarney, J., 1979. The geochemistry of basalts from a back-arc spreading center in the East Scotia Sea. Geochim. Cosmochim. Acta, 43:555-572.

Saunders, A. D., Tarney, J., Weaver, S. D., in press. Transverse geochemical variations across the Antarctic Peninsula: implications for the genesis of calc-alkaline magmas. Earth Planet. Sci. Lett..

Schnetzler, C. C., and Philpotts, J. A., 1970. Partition coefficients of rare-earth elements between igneous matrix material and rockforming mineral phenocrysts, II. Geochim. Cosmochim. Acta, 34: 886-888.

Scott, R. B., and Hajash, A., Jr., 1976. Initial submarine weathering of basaltic pillow lavas: a microprobe study. Am. J. Sci., 276: 480-501.

Shido, F., Myashiro, A. F., and Ewing, M., 1971. Crystallization of abyssal tholeiites. Contrib. Mineral. Petrol., 31:251-266. 1974. Compositional variations in pillow lavas from the Mid-Atlantic Ridge. Mar. Geol., 16:177-190.

Sigurdsson, J., 1976. Spinels in Leg 37 basalts and peridotites; phase chemistry and zoning. In Aumento, F., Melson, W. G., et al., Init. Repts. DSDP, 37: Washington (U.S. Govt. Printing Office), 883-891.

Simkin, T., and Smith, J. V., 1970. Minor element distribution in olivine. J. Geol., 78:304-325.

Spooner, E. T. C., Beckinsale, R. D., Fyfe, W. S., et al., 1974. O18 enriched ophiolitic metabasic rocks from E. Liguria (Italy), Pindos (Greece) and Troodos (Cyprus). Contrib. Mineral. Petrol., 47: 41-51.

Stern, R. J., 1979. On the origin of andesite in the northern Mariana Island Arc: implications from Agrigan. Contrib. Mineral. Petrol., 68:207-219.

Sun, S.-S., Nesbit, R. W., Sharaskin, A., 1979. Chemical characteristics of mid-ocean ridge basalts. Earth Planet. Sci. Lett., 45 119-138.

Tarney, J., Marsh, N., Wood, D., in press. Geochemistry of igneous rocks from the Mariana Trough, Ridge and Forearc: IPOD Leg 60. In Hussong, D., Uyeda, S., et al., Init. Repts. DSDP, 60: Washington (U.S. Govt. Printing Office).
Tarney, J., Saunders, A. D., and Weaver, S. D., 1977. Geochemistry of volcanic rocks from the island arcs and marginal basins of the Scotia Sea Region. In Talwani, M., and Pitman, W. C., III (Eds.), Island Arcs, Deep Sea Trenches, and Back-arc Basins (Vol. I): Washington (Am. Geophys. Union), 367-377.

Tarney, J., Saunders, A. D., Weaver, S. D., et al., 1979. Minor element geochemistry of basalts from Leg 49, North Atlantic Ocean. In Luyendyk, B., Cann, J. R., et al., Init. Repts. DSDP, 49: Washington (U.S. Govt. Printing Office), 657-691.

Tatsumoto, M., 1969. Lead isotopes in volcanic rocks and possible ocean floor thrusting beneath island arcs. Earth Planet. Sci. Lett., 6:369-376.

Thompson, R. N., 1974. Some high pressure pyroxenes. Mineral. Mag., 39:786-787.

1975. Primary basalts and magma genesis, II, Snake River Plane, Idaho. Contrib. Mineral. Petrol., 52:213-232.

Thompson, G., and Humphris, S., 1977. Seawater-rock interactions in the oceanic basement. In Parquet, H., and Tardy, Y. (Eds.), Proceedings 2nd International Symposium on Water-Rock Interaction (Vol. III): Strasbourg (Science Geologique, Université Louis Pasteur), 3-8.

Treuil, M., and Varet, J., 1973. Critères volcanologiques, pétrologiques, et geochimiques de la différentiation des magmas basaltiques; exemple de l'Afar. Bull. Soc. Geol. Fr. 15:506-540.

Uyeda, S., and Kanamori, H., 1979. Back-arc opening and the mode of subduction. J. Geophys. Res., 84:1049-1061.

Watanabe, T., Langseth, M. G., and Anderson, R. N., 1977. Heat flow in back-arc basins of the western Pacific. In Talwani, M., and Pitman, W. C., III (Eds.), Island Arcs, Deep Sea Trenches, and Back-arc Basins (Vol. I): Washington (Am. Geophys. Union) 137-161.

Watson, E. B., 1979. Zircon saturation in Felsic Liquids: experimental results and applications to trace element geochemistry. Contrib. Mineral. Petrol., 70:407-419.

Watts, A. B., and Weissel, J. K., 1975. Tectonic history of the Shikoku marginal basin. Earth Planet. Sci. Lett., 25:239-250.

Watts, A. B., Weissel, J. K., and Larson, R. L., 1977. Sea-floor spreading in marginal basins of the W. Pacific. Tectonophysics, 37:167-187.

Weaver, S. D., Saunders, A. D., Pankhurst, R. J., et al., 1979. A geochemical study of magmatism associated with the initial stages of back-arc spreading: the Quaternary volcanics of Bransfield Strait from South Shetland Islands. Contrib. Mineral. Petrol., 68: 151-169.

Whitford, D. J., and Jezek, P. A., 1979. Origin of Late-Cenozoic Lavas from the Banda arc, Indonesia: the role of subducted sediments in petrogenesis. Geology, 5:571-575.

Wood, D. A., Tarney, J., Varet, J., et al., 1979. Geochemistry of basalts drilled in the North Atlantic by IPOD Leg 49: implications for mantle heterogeneity. Earth Planet. Sci. Lett., 42:77-97.

Wood, D. A., Varet, J., Bougault, H., et al., 1979. The petrology, mineralogy, and geochemistry of North Atlantic basalts: a discussion based on IPOD Leg 49. In Luyendyk, B. P., Cann, J. R., et al., Init. Repts. DSDP, 49: Washington (U.S. Govt. Printing Office) 597-655.

Wright, T. L., 1974. Presentation and interpretation of chemical data for igneous rocks. Contrib. Mineral. Petrol., 48:235-248.

Wright, T. L., and Doherty, P. C., 1970. A linear programming and least-squares computer method for solving petrological mixing problems. Bull. Geol. Soc. Am., 81:1995-2008.

Yoder, H. S., and Tilley, C. E., 1962. Origin of basalt magmas, an experimental study of natural and synthetic rock systems. J. Petrol., $3: 342-532$. 

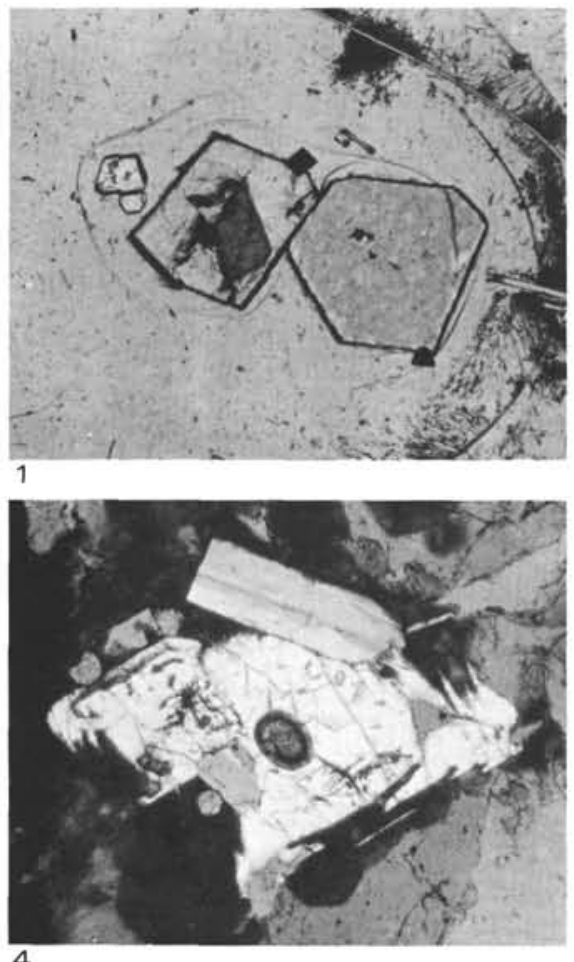

4

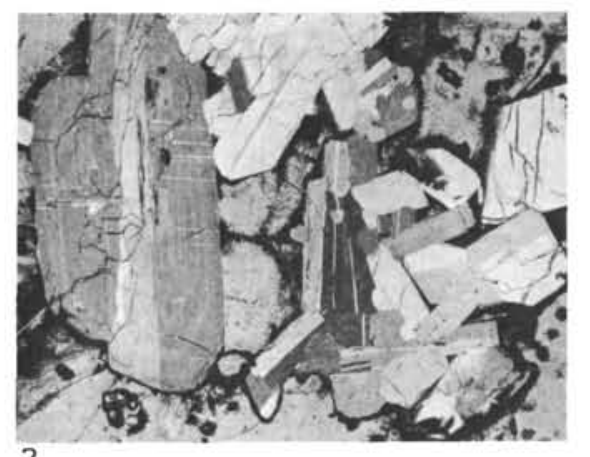

2
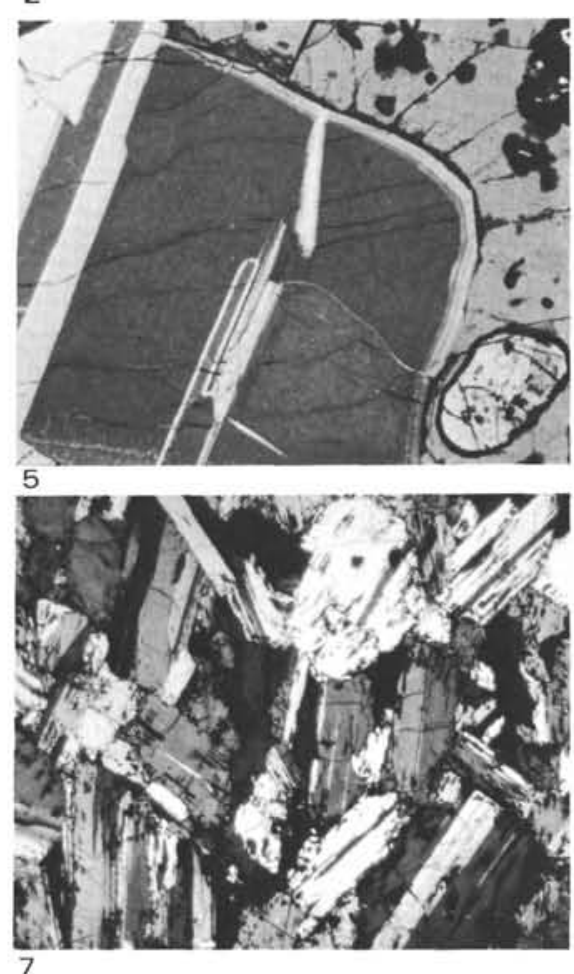
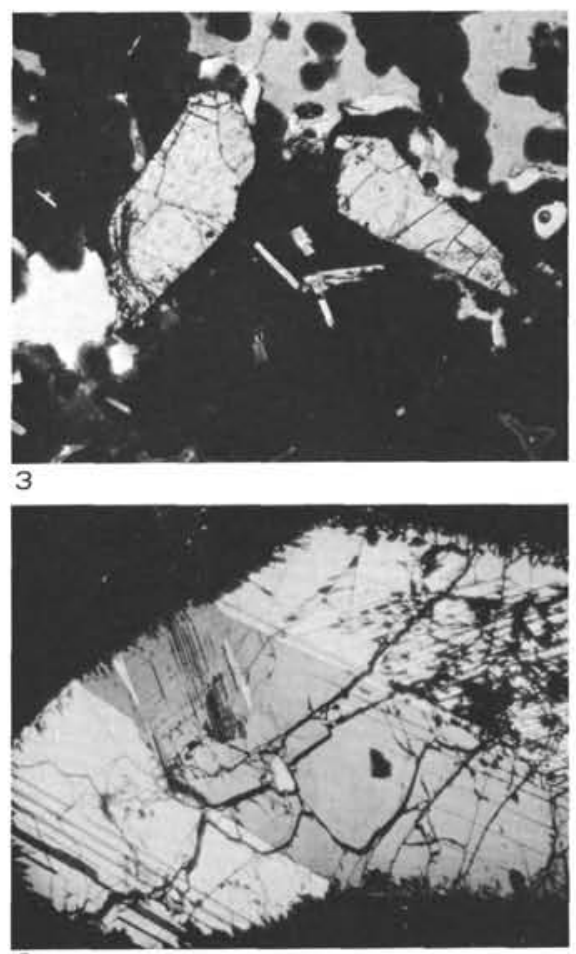

6
Plate 1. Photomicrographs of olivine and plagioclase phenocrysts and xenocrysts and an anorthosite xenolith, Hole 447A.

Figure 1. Typical unzoned euhedral olivine phenocrysts in glassy margin from Unit L6e (C5), Sample 447A-35-2, $145 \mathrm{~cm}$. Note octahedra of magnesiochromite $(\mathrm{Cr} / \mathrm{Cr}+\mathrm{Al} \sim 0.53)$ adhering to surfaces of the olivine phenocrysts. Olivine composition $\mathrm{Fo}_{88}$; partially crossed polarizers; width of photograph $1 \mathrm{~mm}$.

Figure 2. Glomerophyric group of euhedral, oscillatory-zoned plagioclase phenocrysts, with rare olivine (the sample is the same as in Fig. 1); plagioclase composition $\mathrm{An}_{88-82}$, partly crossed polarizers; width of photograph $2.5 \mathrm{~mm}$.

Figure 3. Anhedral resorbed xenocrysts(?) of olivine $\left(\mathrm{Fo}_{85}\right.$, Table 8 , Anal. 3) in glassy margin from Unit L3a (C2), Sample 447A-17-1, $146 \mathrm{~cm}$; plane polarized light; width of photograph $2 \mathrm{~mm}$.
Figure 4. Skeletal, quench-textured olivine $\left(\mathrm{Fo}_{82}\right)$ from the same sample as Figure 3; partly crossed polarizers; width of photograph $1 \mathrm{~mm}$.

Figure 5. Calcic plagioclase xenocryst $\left(\mathrm{An}_{95}\right.$, Table 7, Anal. 3) from Unit L3a (C2), Sample 447A-16-2, $45 \mathrm{~cm}$; unzoned core with thin oscillatory-zoned overgrowth of more sodic plagioclase $\left(\sim \mathrm{An}_{80}\right)$. Note smooth subhedral outline, and strongly resorbed endiopsidic augite, containing glass inclusions, in lower right-hand corner of photograph. Partly crossed polarizers; width of photograph $3.5 \mathrm{~mm}$.

Figure 6. Less-calcic plagioclase xenocryst $\left(\mathrm{An}_{84}\right.$, Table 7, Anal. 6) from Unit L6f (C5), Sample 447A-36-3, $40 \mathrm{~cm}$. Note more ragged outline. Crossed polarizers; width of photograph $5 \mathrm{~mm}$.

Figure 7. Anorthosite xenolith from Unit L6f (C5); plagioclase composition $\mathrm{An}_{82-80}$; crossed polarizers; width of photograph $5 \mathrm{~mm}$. 

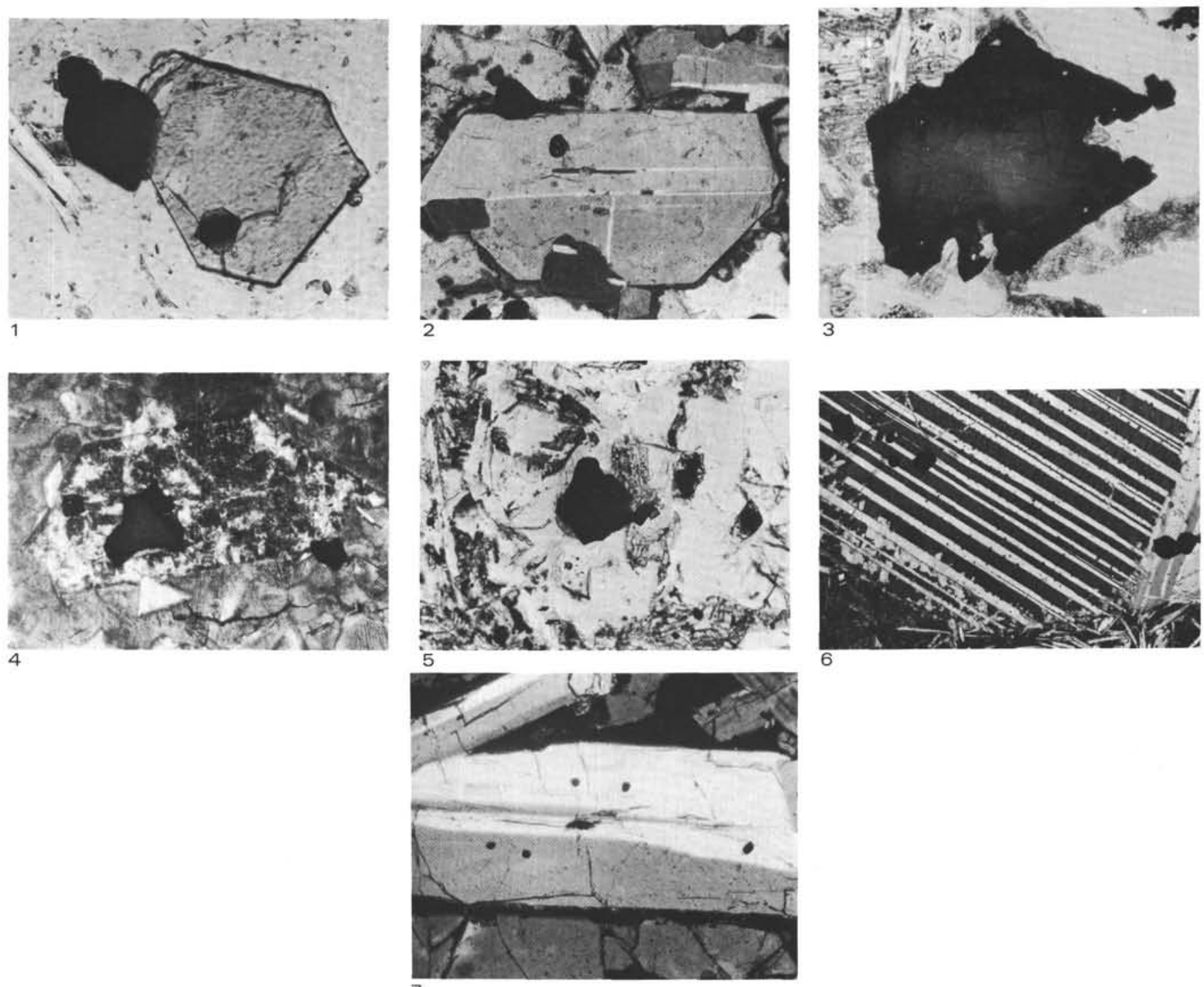

6

Plate 2. Photomicrographs of spinel phenocrysts and xenocrysts from Hole 447A.

Figure 1. Euhedral octahedral magnesiochromites embedded or adhering to olivine microphenocryst $\left(\mathrm{Fo}_{87}\right)$ from Unit L6f (C5), Sample $447 \mathrm{~A}-36-4,77 \mathrm{~cm}$; partly crossed polarizers width of photograph $0.5 \mathrm{~mm}$.

Figure 2. Euhedral magnesiochromite adhering to plagioclase phenocryst from Unit L6e (C5), Sample 447A-31-4, $35 \mathrm{~cm}$; partly crossed polarizers; width of photograph $1 \mathrm{~mm}$.

Figure 3. Etched translucent chromian-spinel, free floating in Unit L6f (C5), Sample 447A-36-1, $95 \mathrm{~cm}$; plane polarized light; width of photograph $0.5 \mathrm{~mm}$.

Figure 4. Smectite pseudomorph after olivine phenocryst containing resorbed anhedral chromian-spinel from Unit L6f (C5), same sam- ple as Plate 1, Figure 6. Spinel adhering to phenocryst is unresorbed, $\mathrm{Cr}$-rich magnesiochromite. Plane polarized light; width of photograph $1 \mathrm{~mm}$.

Figure 5. Anhedral resorbed chromian-spinel, almost completely redigested, from Unit L6f (C5), same sample as Figure 3; plane polarized light; width of photograph $0.5 \mathrm{~mm}$.

Figure 6. Large subhedral chromian-spinels in margin of "lesscalcic" plagioclase xenocryst from Unit L6f (C5), same sample as Figures 3 and 5; crossed polarizers; width of photograph $3.5 \mathrm{~mm}$.

Figure 7. Very small, round, resorbed spinels in plagioclase phenocryst from Unit L3a (C2), Sample 447A-16-2, $45 \mathrm{~cm}$ (enlargement of Plate 3, Figure 2); partly crossed polarizers; width of photograph $1 \mathrm{~mm}$. 

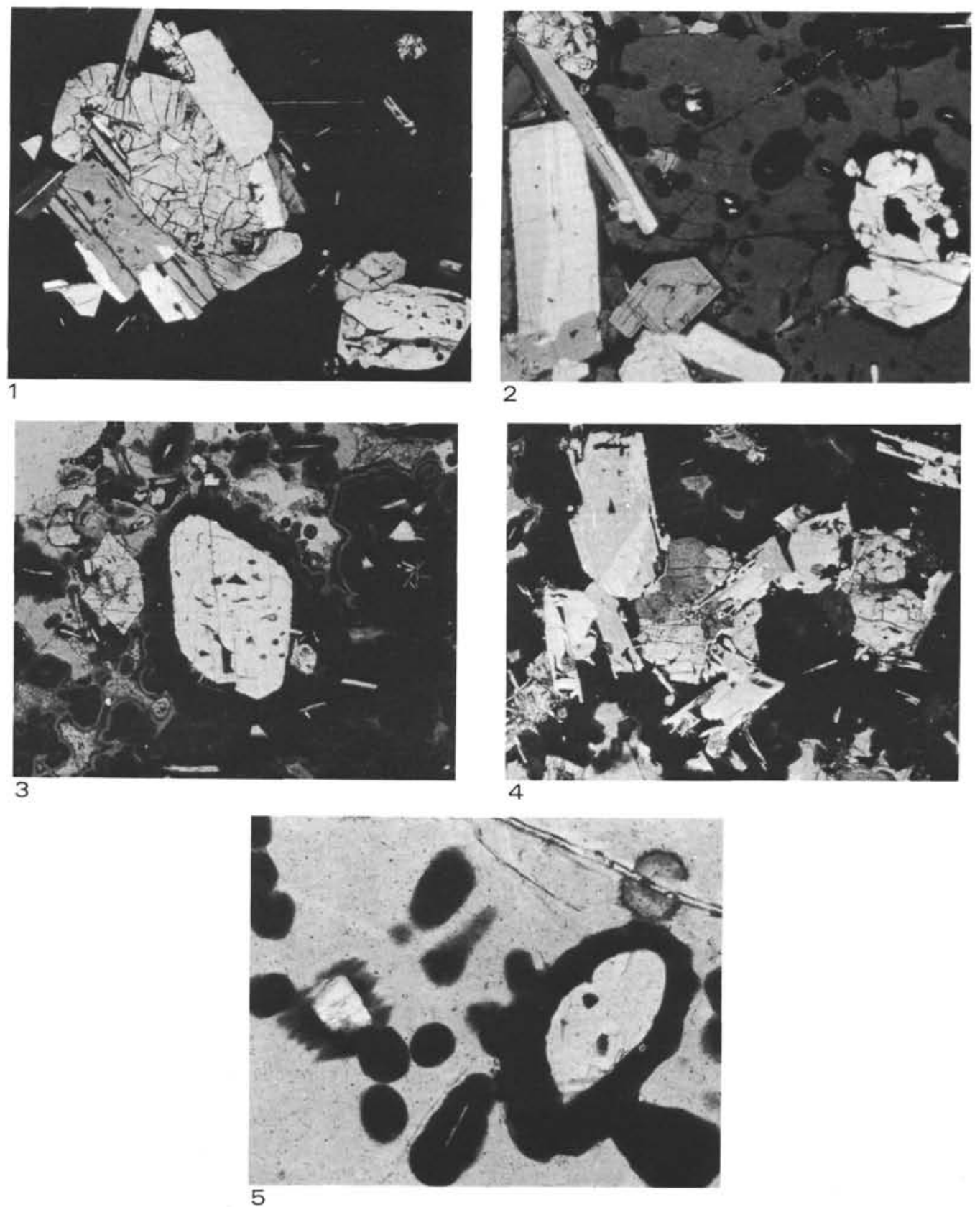

Plate 3. Photomicrographs of clinopyroxene xenocrysts and of a glomerocryst from Hole 447A.

Figure 1. Resorbed $\mathrm{Cr}$-rich endiopside (top left) surrounded by plagioclase phenocrysts $\left(\mathrm{An}_{80}\right)$ and resorbed crystal of less $\mathrm{Cr}$-rich endiopside containing glass inclusions (lower right) from Unit L3a (C2), Sample 447A-17-1, $148 \mathrm{~cm}$; partly crossed polarizers; width of photograph $2.5 \mathrm{~mm}$.

Figure 2. Embayed crystal of $\mathrm{Cr}$-rich endiopside from Unit L3a (C2), Sample 447A-16-2, $45 \mathrm{~cm}$ same sample as Plate 1, Figure 5). Note oscillatory-zoned plagioclase phenocrysts containing small round chromian-spinels (Plate 2, Fig. 7). Width of photograph $2.5 \mathrm{~cm}$.
Figure 3. Resorbed Cr-rich endiopside from Unit L3a (C2), Sample $447 \mathrm{~A}-18-1,40 \mathrm{~cm}$. Note rounded outline with fresh glass inclusions. The photograph also shows a skeletal olivine microphenocryst. Partly crossed polarizers; width of photograph $1.5 \mathrm{~mm}$.

Figure 4. Glomerophyric intergrowth of $\mathrm{Cr}$-poor, Ti-rich endiopsidic augite with euhedral and skeletal plagioclase phenocrysts (Sample $447 \mathrm{~A}-18-1,40 \mathrm{~cm})$. Note the irregular grain boundaries and patchy extinction of the pyroxene crystals. Partly crossed polarizers; width of photograph $2.5 \mathrm{~mm}$ (same sample as Plate 3, Fig. 3).

Figure 5. Almost completely redigested $\mathrm{Cr}$-rich endiopsidic augite from Unit L3d (C3), Sample 447A-22-1, $20 \mathrm{~cm}$. 